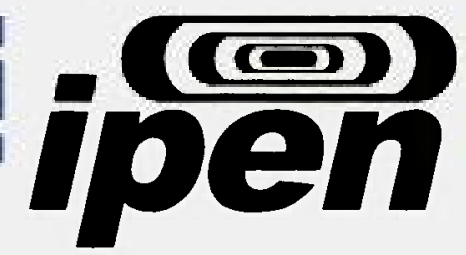

AUTARQUIA ASSOCIADA À UNIVERSIDADE DE SÃO PAULO

\title{
ABORDAGEM SISTÊMICA DO SISTEMA DE TRATAMENTO DE ÁGUA DE REGISTRO, SÃO PAULO, COM ÊNFASE NA AVALIAÇÃO DO IMPACTO DO DESCARTE DOS RESÍDUOS NA BACIA HIDROGRÁFICA DO RIO RIBEIRA DE IGUAPE
}

\section{EDSON LUIS TOCAIA DOS REIS}

Tese apresentada como parte dos requisitos para obtenção do Grau de Doutor em Ciências na Área de Tecnologia Nuclear - Materiais.

Orientador:

Dr. Cláudio Rodrigues

Co-orientadora:

Dra. Maria Aparecida F. Pires 


\section{$c=0$}

(1)

(1)

INSTITUTO DE PESQUISAS ENERGÉTICAS E NUCLEARES Autarquia Associada à Universidade de São Paulo

\section{Abordagem Sistêmica do Sistema de Tratamento de Água de Registro, São Paulo, com Ênfase na Avaliação do Impacto do Descarte dos Resíduos na Bacia Hidrográfica do Rio Ribeira de Iguape.}

\section{Edson Luís Tocaia dos Reis}

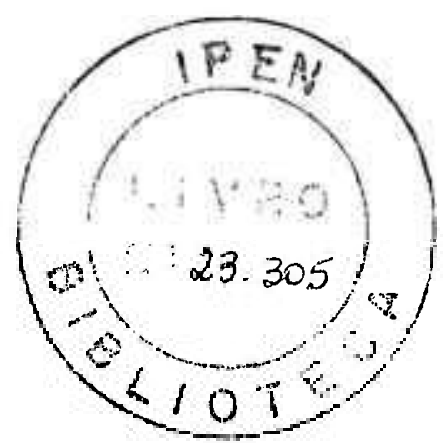

Tese apresentada como parte dos requisitos para obtenção do Grau de Doutor em Ciências na Área de Tecnologia Nuclear - Materiais.

Orientador: Dr. Cláudio Rodrigues

Co-orientadora: Dra. Maria Aparecida F. Pires

SÃO PAULO 


\section{AGRADECIMENTOS}

Ao Dr. Cláudio Rodrigues e a Dra. Maria Aparecida Faustino Pires, pela orientação prestada além da oportunidade e confiança em desenvolver um projeto tão importante.

À Fundação de Amparo à Pesquisa do Estado de São Paulo - FAPESP, por meio dos auxilios financeiros nos processos 00/02024-4 e 03/06419-1: "Gerenciamento de Lodos de ETAs. Influência do Lançamento do Lodo de ETA no Processo de Tratamento de Esgotos por Lagoas de Estabilização em Cidades de Pequeno Porte", e a CAPES e ao $\mathrm{CNPq}$, pelas bolsas concedidas ao longo do período de estudo.

Ao Instituto de Pesquisas Energéticas e Nucleares - IPEN - CNEN/SP, pela oportunidade na realização do trabalho.

Ao Osvaldo Beltrame Filho, Gerente da Divisão de Controle Sanitário da Unidade de Negócios do Vale do Ribeira, da Companhia de Saneamento do Estado de São Paulo (SABESP), pelo apoio irrestrito à execução de todo o projeto, bem como a todos os funcionários da ETA de Registro, que diretamente ou não, contribuíram para o trabalho, especialmente aos biólogos Guilherme da Silva, Ivon Villanova, Júlio César de Morais e Diomedes (Belo) pelo envolvimento no projeto e informações técnicas prestadas.

Às pesquisadoras do CQMA Dra. Marlene Flues e Dra. Nilce Ortiz, pela amizade e incentivo nas discussões e informações técnicas tão importantes nas análises de lodo e sedimentos.

Aos pesquisadores Msc. Marycel Cotrim, responsável pelo Laboratório de Análises Químicas e Ambientais e vice - coordenadora do projeto FAPESP e Dr. Hélio Furusawa pelo apoio técnico e informações necessárias aos ensaios no ICP-OES.

Às pesquisadoras Dra. Silvana Audrá Cutolo e Dra. Solange Martone Rocha, da Faculdade de Saúde Pública, Departamento de Saúde Ambiental, Universidade de São Paulo, pelos ensaios e esclarecimentos relativos às análises de organismos bentônicos nas amostras de sedimento. 
Aos alunos de iniciação científica André de Souza, Paula Amalfi e Rose Zancanella pela excepcional ajuda ao trabalho "bandeirante" nas coletas das amostras, além da execução eficiente das análises de lodo, água e sedimento.

Aos alunos de pós-graduação do CQMA Ajibola Badiru e Maria Nogueira Marques pelo companheirismo e interesse mútuo demonstrado na execução de projetos ambientais em uma área tão especial quanto o Vale do rio Ribeira de Iguape.

A todos os funcionários do CQMA, especialmente a Cida, Cleide, Cristina, Denise, Iara, Elias, Marta, Josefa e Neuza pelo apoio e carinho.

Aos professores Elide Mastena e André Paz por me abrirem as portas do mundo, graças aos seus ensinamentos de inglês e espanhol.

Aos amigos Edson Marson, Fátima Vieira, Silvana Mejias e Suzi Satiko por estarem presentes em todas as horas e me ajudarem a trilhar meu caminho cada vez melhor.

A toda minha familia pela contribuição à minha formação.

Ao meu tio Milton Reis, por sua ajuda inicial em um momento decisivo em minha vida. 
"Nada é mais poderoso do que uma idéia que chegou no tempo certo"

[Victor Hugo] 


\section{ABORDAGEM SISTÊMICA DO SISTEMA DE TRATAMENTO DE ÁGUA DE REGISTRO, SÃO PAULO, COM ÊNFASE NA AVALIAÇÃO DO IMPACTO DO DESCARTE DOS RESÍDUOS NA BACIA HIDROGRÁFICA DO RIO RIBEIRA DE IGUAPE.}

\section{EDSON LUÍS TOCAIA DOS REIS}

\section{RESUMO}

A crescente preocupação dos órgãos de vigilância ambiental e sanitária sobre a segurança e a qualidade dos recursos hídricos tem orientado o desenvolvimento de diversas pesquisas voltadas para uma revisão do padrão tecnológico atual, quanto à gestão de resíduos gerados em estações de tratamento de água. Neste trabalho, foram avaliadas as principais características dos resíduos gerados em um sistema de tratamento de água de ciclo completo na cidade de Registro (SP) e sua correlação com a qualidade do meio hidrico, pelo estudo dos efeitos fisico-químicos de seu descarte na qualidade da água e do sedimento da Bacia Hidrográfica do rio Ribeira de Iguape. Um programa de monitoramento da microbacia foi estabelecido, verificando-se o atendimento dos elementos analisados às exigências de legislações federais, como a Resolução CONAMA 357/2005 e a Portaria 518. Foram constatadas alterações na qualidade da água superficial do corpo d'água receptor em períodos de até 4 horas, após o despejo, e para uma distância de até $50 \mathrm{~m}$ a jusante do descarte do lodo da ETA. A análise descritiva mostrou ser predominante a concentração de alguns metais durante $\mathrm{o}$ descarte, como o manganês. A análise dos organismos bentônicos apresentou uma indicação de que os grupos observados não foram diretamente afetados pelo despejo do lodo da ETA. O presente trabalho não detectou indícios de que a contaminação constatada no local de despejo atingisse o rio Ribeira de Iguape, porém, a presença de alumínio em amostras de sedimento próximo ao local de descarte mostrou que o descarte sistemático do lodo pode comprometer em longo prazo a qualidade da água do corpo d'água receptor. 


\title{
SISTEMIC APPROACH OF WATER TREATMENT PLANT OF REGISTRO, SÃO PAULO, FOCUSING THE EVALUATION OF THE IMPACT OF THE DISCHARGE OF SOLID RESIDUES IN RIBEIRA DE IGUAPE RIVER BASIN
}

\author{
EDSON LUÍS TOCAIA DOS REIS
}

\begin{abstract}
The growing concern of environmental and sanitary surveillance about the safety and the quality in the hydric resources, guides the development of many researches to a revision of the current technological pattern, related to the administration of residues generated in the water treatment plants. This work evaluated main characteristics of the residues generated in water treatment plant with complete cycle in the Registro town (SP) and the correlation with quality of the environment, by studying physical-chemical effects of its discharge in the quality of water and sediment of Ribeira de Iguape River Basin. A monitoring program was established, verifying the attendance of the elements analyzed to the demands of federal legislations, such as Resolução CONAMA 357/2005 and Portaria 518. Some alterations were verified in the quality of superficial water of the receiving watercourse, in periods up to 4 hours after the discharge and for a distance of $50 \mathrm{~m}$ to the place of the discard of sludge. The descriptive analysis showed to be predominant the concentration of some metals during the discharge, as manganese. The analysis of the benthonic organisms pointed out that the groups observed as typical of the area were not directly affected by sludge discharge. The present study did not detect indications that the contamination verified reached Ribeira de Iguape River. However, the systematic discharging of the sludge may commit at long date the water quality of the receiving watercourse.
\end{abstract}




\section{SUMÁRIO}

Página

RESUMO

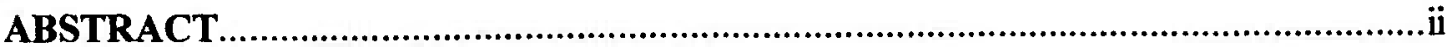

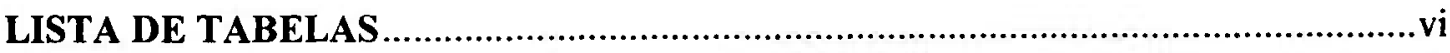

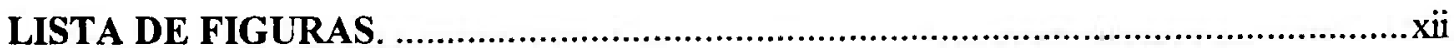

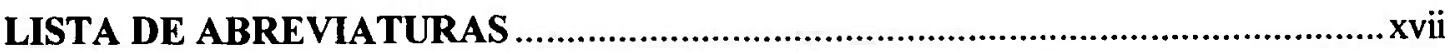

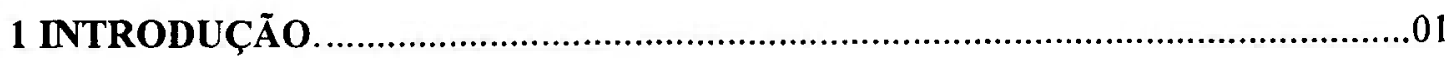

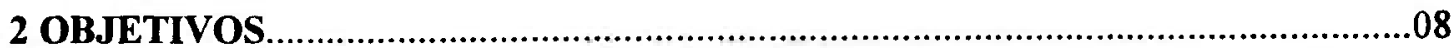

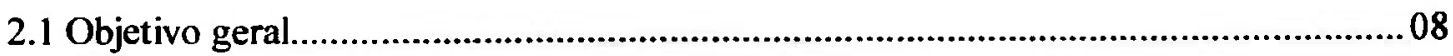

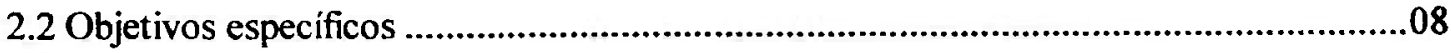

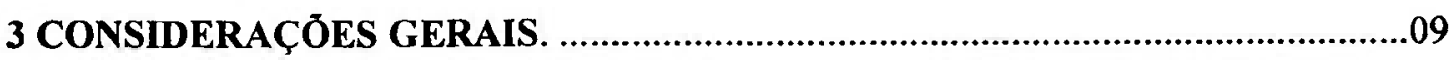

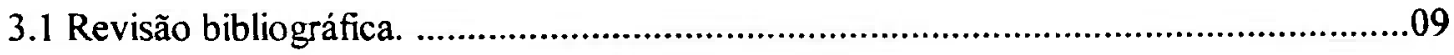

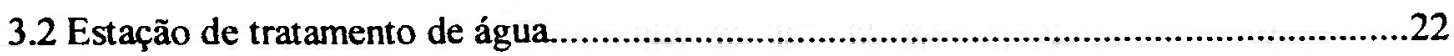

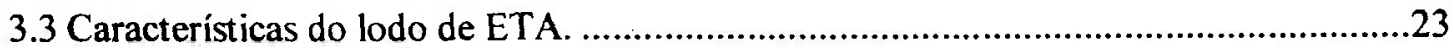

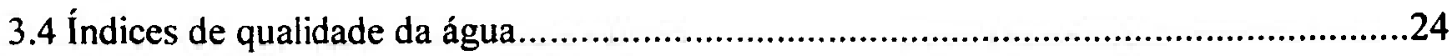

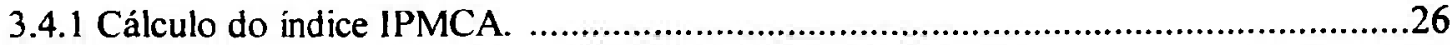

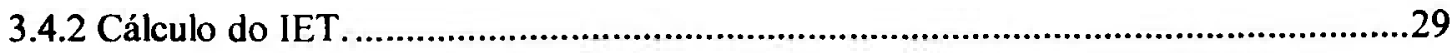

3.5 Avaliação do impacto ambiental. .............................................................................30

3.5.1 Avaliação das amostras de águas superficiais e sedimentos.......................................33

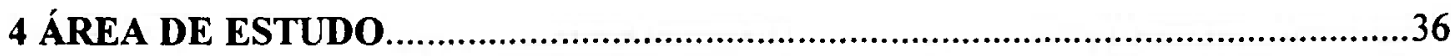

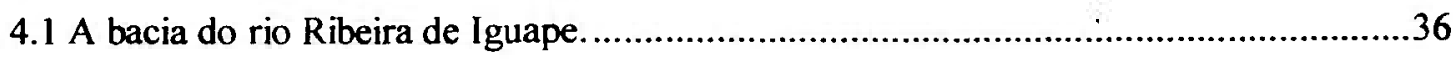

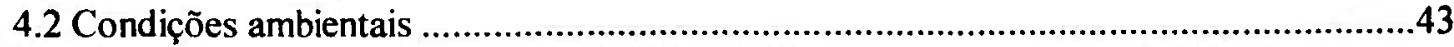

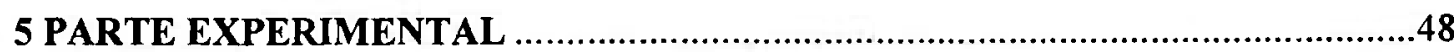

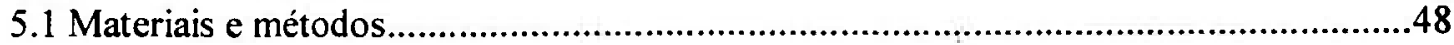


5.1.2 Reagentes e soluções .48

5.1.3 Determinação de metais e elementos traço por ICP-OES ....................................49

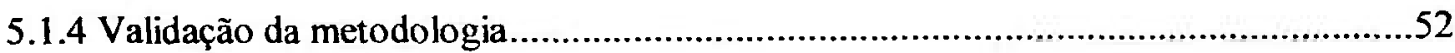

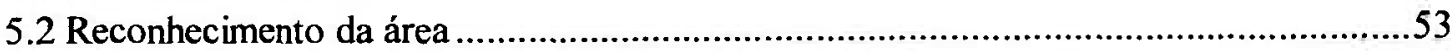

5.2.1 Análise das condições climáticas ............................................................53

5.2.2 Caracterização do sistema de tratamento de água.............................................53

5.3 Caracterização das variáveis físico-químicas ..................................................55

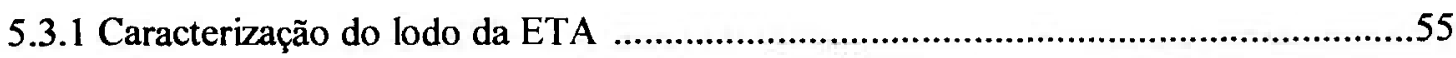

5.3.2 Caracterização físico-química da água no sistema de tratamento e no processo de

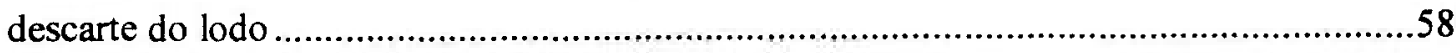

5.3.3 Caracterização da qualidade da água e do sedimento.........................................59

5.3.4 Cálculo da vazão dos cursos d'água receptores do lodo da ETA ...........................64

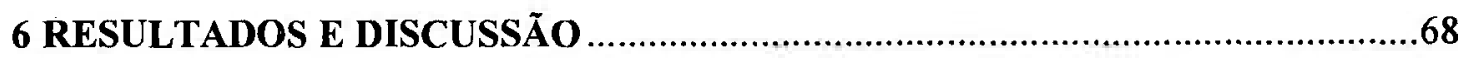

6.1 Caracterização da ETA de Registro (SABESP/SP) ...........................................68

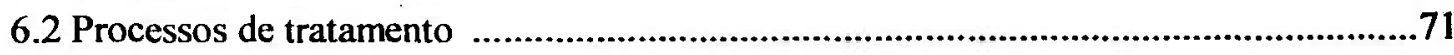

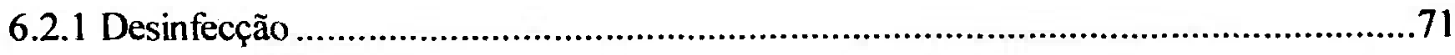

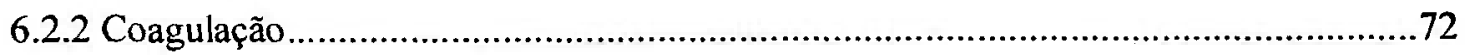

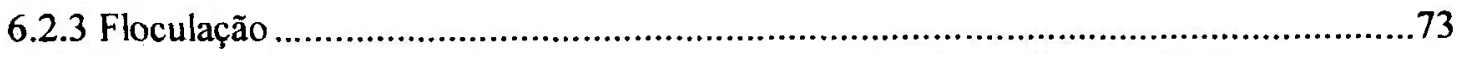

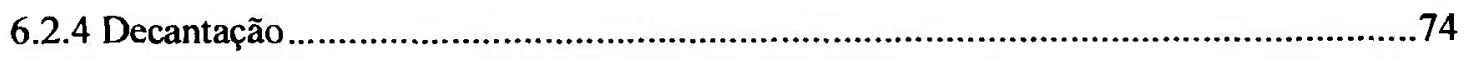

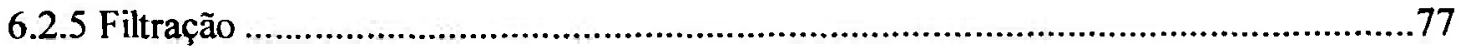

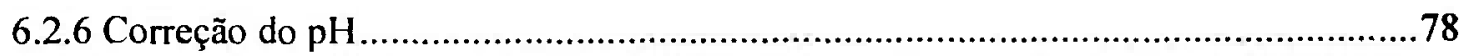

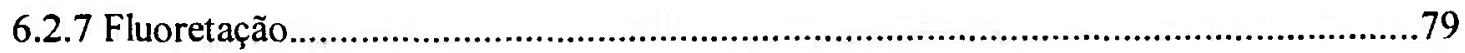

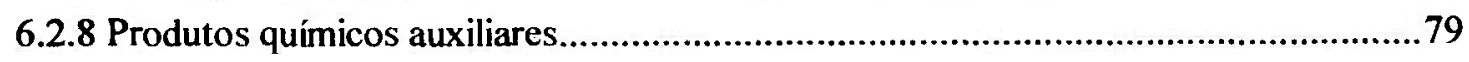

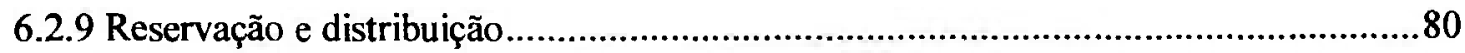

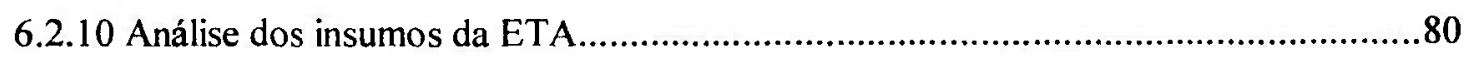

6.3 Qualidade da água bruta e monitoramento das condições climáticas .........................83

6.4 Caracterização química do lodo da ETA ..............................................................8 88

6.4.1 Caracterização física e geomorfológica das amostras de lodo.............................89

6.4.2 Avaliação mineralógica ......................................................................91

6.4.3 Caracterização dos metais lixiviáveis no lodo .............................................. 93 
6.5 Avaliação físico-química da água no sistema de tratamento e no descarte do lodo .......99

6.6 Tratamento matemático e estatístico dos dados utilizando gráficos ternários .............105

6.7 Avaliação do impacto do despejo da ETA no curso d’água ................................ 107

6.8 Análise das amostras de águas superficiais ..................................................... 113

6.9 Cálculos dos índices de qualidade de água................................................ 126

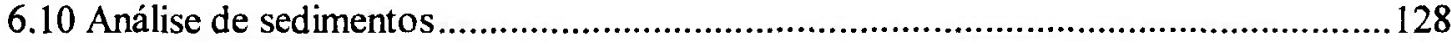

6.10.1 Avaliação estatística dos resultados de sedimentos por análise de correlação ........134

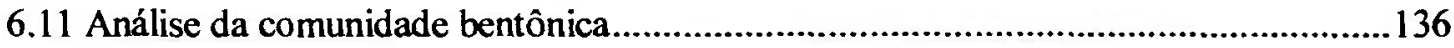

6.12 Considerações sobre tratamento e disposição de lodo de ETA em cidades de pequeno

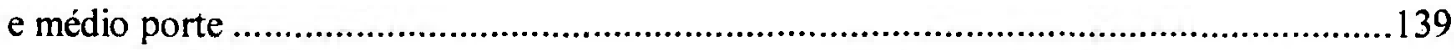

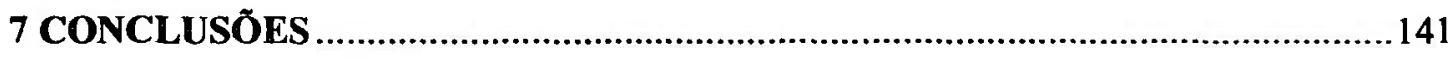

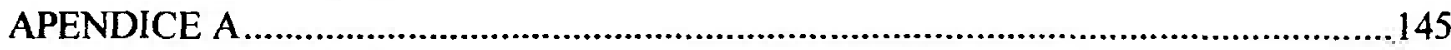

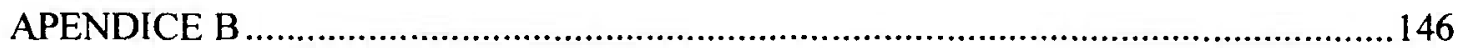

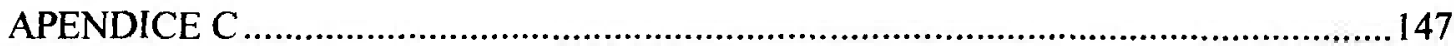

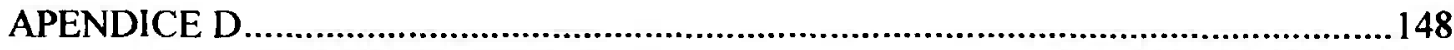

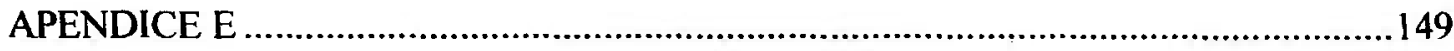

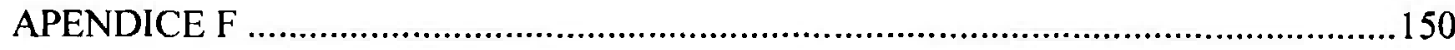

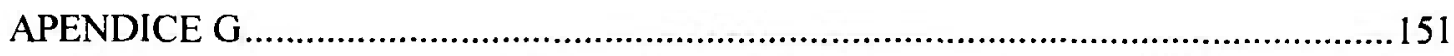

APENDICE H..................................................................................... 152

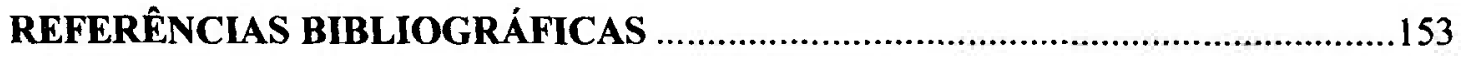




\section{LISTA DE TABELAS}

TABELA 1 - Municípios, total e com serviço de abastecimento de água, segundo as Grandes Regiões - 1989-2000.

TABELA 2 - Número de distritos brasileiros abastecidos com sistemas de tratamento de água, por tipo de tratamento -2000 .

TABELA 3 - Número de distritos brasileiros cuja água tratada passa por processo de coagulação química, e por destino do lodo gerado -2000 .

TABELA 4 - Métodos de disposição final de lodo de ETA, em diferentes paises.

TABELA 5 - Vantagens e desvantagens de algumas alternativas para tratamento e disposição do lodo de ETA.

TABELA 6 - Regulamentos no âmbito federal e estadual que regem sobre a importância do gerenciamento da quantidade e da qualidade dos recursos hídricos. 18

TABELA 7 - Classificações de qualidade das águas - IVA 26

TABELA 8 - Parâmetros do IPMCA, conforme niveis de qualidade.

TABELA 9 - Classificação do valor do IPMCA para avaliação da qualidade da água........28

TABELA 10 - Classificação do Índice do Estado Trófico (IET), segundo Índice de Carlson modificado .30

TABELA 11 - Características dos principais parâmetros analisados. 
TABELA 12 - Influência de mudanças químicas em metais potencialmente disponiveis.....34

TABELA 13 - Unidades de conservação do Vale do Ribeira e litoral sul do estado de São Paulo: municípios abrangidos, instrumento legal de criação e área em ha.

TABELA 14 - Produção estimada de lodo das ETAs no Vale do Ribeira.

TABELA 15 - Resenha das condições ambientais da cidade de Registro, no período de Nov./2003 até Fev./2005. .44

TABELA 16 - Condições de operação do sistema (ICP-OES). .50

TABELA 17 - Linhas de emissão, intervalos de linearidade e limites de quantificação dos elementos analisados para a determinação por ICP-OES das amostras de águas superficiais e sedimentos de coletas dos cursos d'água receptores do lodo da ETA. .51

TABELA 18 - Reprodutibilidade, precisão e desvio padrão relativo para a análise do material de referência SRM-1643c, por ICP-OES. .52

TABELA 19 - Caracterização da Área de Estudo: ETA, ETE, captações, corpo receptor e observações relevantes. .54

TABELA 20 - Teores certificados e determinados por Espectrometria de Fluorescência de Raios X por dispersão de comprimento de onda para o material de referência CRM-2704 Buffalo River Sediment (NIST). .57

TABELA 21 - Identificação dos pontos de coleta. .58

TABELA 22 - Parâmetros para a avaliação das amostras de efluentes da ETA. .59 
TABELA 23 - Principais parâmetros para qualidade de águas.

TABELA 24 - Caracterização e localização dos pontos de coleta (água superficial e sedimento de fundo. .62

TABELA 25 - Parâmetros para a avaliação das amostras de água superficial .64

TABELA 26 - Vazões do rio Ribeira de Iguape no município de Registro (1960-2000) ....67

TABELA 27 - Caracterização e localização dos sistemas produtores do município de Registro, no Vale do Ribeira. .68

TABELA 28 - Caracteristicas dos floculadores da ETA de Registro. .73

TABELA 29 - Principais características dos decantadores da ETA de Registro .75

TABELA 30 - Características dos filtros da ETA de Registro. .77

TABELA 31 - Principais características do meio filtrante. .78

TABELA 32 - Produtos químicos utilizados. .79

TABELA 33 - Normas NBR relativas aos materiais de tratamento utilizados na ETA. .....81

TABELA 34 - Parâmetros para controle de sulfato de alumínio líquido. .82

TABELA 35 - Consumo dos insumos pela ETA de Registro .82

TABELA 36 - Composição química do sulfato de alumínio adicionado como coagulante (em mg. $\mathrm{L}^{-1}$ ), nos meses de dezembro de 2003 e janeiro e abril de 2004. 
TABELA 37 - Qualidade da água bruta do rio Ribeira de Iguape (na área de captação da ETA de Registro) e da água tratada, para abastecimento. .84

TABELA 38 - Teor de metais na água bruta do rio Ribeira de Iguape (na área de captação da ETA de Registro). 84

TABELA 39 - Condições climáticas da cidade de Registro no periodo de 01/11/2003 a $31 / 12 / 2004$ e quantidades de sulfato de alumínio adicionado como coagulante. .86

TABELA 40 - Estimativa da quantidade de lodo gerado pela ETA de Registro, no período de Nov./2003 e Ago/2004, a partir da média mensal de alguns parâmetros. .87

TABELA 41 - Impactos típicos do tipo de manancial sobre a produção de resíduos 88

TABELA 42 - Resultados obtidos a partir dos principais parâmetros físico-químicos avaliados nas amostras de lodo. .89

TABELA 43 - Caracterização semi-quantitativa por FRX, de amostras de lodo proveniente de diferentes ETAS pertencentes à Bacia Hidrográfica do Ribeira de Iguape. .90

TABELA 44 - Concentrações médias dos analitos (mg. $\mathrm{kg}^{\text {21 })}$ em diferentes frações de digestão, em amostras de lodo seco, por periodo de coleta. .94

TABELA 45 - Intervalo de concentração e concentrações médias dos analitos $\left(\mathrm{mg} . \mathrm{kg}^{\circ}\right) \mathrm{em}$ diferentes frações de 3 amostras de lodo seco. .96

TABELA 46 - Distribuição das frações parciais e lixiviáveis em relação à concentração total de cada elemento analisado, para cada mês de coleta. .97 
TABELA 47 - Distribuição entre elementos-traços analisados em diferentes frações.

TABELA 48 - Variação da concentração (mg. $\left.L^{-1}\right)$ dos metais dissolvidos ao longo do processo de tratamento, entre os meses de junho e julho de 2004. 100

TABELA 49 - Caracterização do corpo receptor quanto à série de sólidos, pH e turbidez, durante o período até $6 \mathrm{~h}$ após o início do descarte do lodo. 108

TABELA 50 - Caracterização do corpo receptor quanto a metais e elementos-traço durante o processo de descarte de lodo pela ETA 110

TABELA 51 - Concentrações de metais em níveis de traços na fração solúvel de amostras de águas superficiais nos pontos de coleta, obtidos em cada mês do período do monitoramento, em um dia após o descarte. 116

TABELA 52 - Concentrações (mg. $\mathrm{L}^{-1}$ ) de metais em níveis de traços na fração solúvel de amostras de águas superficiais nos pontos de coleta 118

TABELA 53 - Parâmetros considerados no periodo de chuvas (Dez/03 - Fev/04). 126

TABELA 54 - Parâmetros considerados no período de estiagem (Jun/04 - Ago/04). 126

TABELA 55 - Valores de IET (P), para os períodos de chuvas e estiagem. 127

TABELA 56 - Classificação do estado trófico 127

TABELA 57 - Concentrações (em mg.kg ${ }^{-1}$ ) e niveis de efeitos (PEL/TEL) dos metais encontrados nas amostras de sedimentos do fundo dos rios Sem Nome, Ribeirão de Registro e Ribeira de Iguape, coletados no período de chuvas. 129 
TABELA 58 - Concentrações (em mg. $\mathrm{kg}^{-1}$ ) e níveis de efeitos (PEL/TEL) dos metais encontrados nas amostras de sedimentos do fundo dos rios Sem Nome, Ribeirão de Registro e Ribeira de Iguape, coletados no período de estiagem. 130

TABELA 59 - Coeficientes de correlação para os pontos de coletas, considerando os elementos analisados nas amostras de sedimento no período de chuvas

TABELA 60 - Coeficientes de correlação para os pontos de coletas, considerando os elementos analisados nas amostras de sedimento no periodo de estiagem

TABELA 61 - Composição da comunidade bentônica nas estações de amostragem, em amostras de sedimentos. 136

TABELA 62 - Processos alternativos para o gerenciamento de lodo de ETAs. 138 


\section{LISTA DE FIGURAS}

FIGURA 1 - Despejo de lodo de ETA de Registro em um curso d'água.

FIGURA 2 - Classificação das 22 unidades de gerenciamento de recursos hídricos (UGRHI) do estado de São Paulo. .21

FIGURA 3 - Localização da cidade de Registro 21

FIGURA 4 - Esquema de sistema de estação de tratamento de água. 23

FIGURA 5 - Localização da bacia hidrográfica do Ribeira de Iguape. 37

FIGURAS 6 a 9 - Representação fotográfica do período de cheia do rio Ribeira de Iguape, observado na região urbana (FIG.6 e 7) e rural (FIG.8 e 9). Ao fundo, na FIG.9, observa-se a estação de captação de água de ETA de Registro, às margens do rio Ribeira de Iguape..45

FIGURAS 10 a 13 - Variação observada no ano de 2003 nos mesmos locais no Ribeirão de Registro (FIG.10 e 11) e no rio Sem Nome (FIG.12 e 13), na cidade de Registro, nos períodos de estiagem e chuvas, respectivamente. 46

FIGURAS 14 e 15 - Coleta de amostras de lodo de ETA no tanque de decantação, seguido de homogeneização para amostra representativa. .56

FIGURA 16 - Localização dos pontos de coleta - Bacia Hidrográfica do rio Ribeira de Iguape, Rio Sem Nome, Registro, SP.

FIGURA 17 - Seção do rio Sem Nome próximo à ETA de Registro.

FIGURA 18 - Representação fotográfica da ETA de Registro (SABESP). 
FIGURA 19 - Estação de captação de água no rio do Ribeira de Iguape (SABESP). 69

FIGURA 20 - Captação de água no rio do Ribeira de Iguape (SABESP). 70

FIGURA 21 - Entrada de água na ETA de Registro, proveniente da estação de captação..71

FIGURA 22 - Monitores e dosadores automáticos para a adição de floculantes e coagulantes pela ETA de Registro.. 73

FIGURA 23 - Tanques de floculação e coagulação, ETA de Registro. .74

FIGURA 24 - Decantador da ETA de Registro, com o lodo depositado. 75

FIGURA 25 - Representação esquemática de um decantador de uma ETA. .76

FIGURA 26 - Tanque de decantação com saída de água para a fase de filtragem. .76

FIGURA 27 - Liberação do lodo retido no decantador. .77

FIGURA 28 - Saída dos tanques de filtração para cloração e abastecimento 80

FIGURA 29 - Perfil das condições ambientais temperatura média $\left({ }^{\circ} \mathrm{C}\right)$ e indice pluviométrico $(\mathrm{mm})$ com relação à turbidez da água bruta e volume de água tratada da ETA de Registro $\left(\mathrm{m}^{3}\right)$, no período de março de 2003 a janeiro de 2004 .85

FIGURAS 30 e 31 - Difratograma de duas amostras de lodo de ETA coletadas em periodos de chuvas e estiagem ( fevereiro e agosto de 2004, respectivamente).

FIGURAS 32 e 33: Fotomicrografia eletrônica de varredura, mostrando detalhes morfológicos (SEM - 10.000x) das partículas de lodo de ETA. 
FIGURA 34 - Perfil do processo de tratamento de água e descarte, a partir da análise de $\mathrm{Na}, \mathrm{Mg}, \mathrm{K}, \mathrm{Ca}, \mathrm{Fe}, \mathrm{Ba}, \mathrm{Al}$ e Mn presentes no lodo da ETA de Registro. 101

FIGURA 35 - Perfil do $\mathrm{pH}$ no processo de descarte do lodo do decantador e do filtro. ..102

FIGURA 36 - Variação das medidas de turbidez do despejo da ETA, período junho e julho de 2004 . 103

FIGURA 37 - Córrego da ETA, no período de estiagem. (Agosto/2004). 104

FIGURA 38 - Gráficos ternários correlacionando os elementos $\mathrm{Ca}, \mathrm{Mg}$ e $\mathrm{Mn}$ presentes na fração solúvel do despejo, nas primeiras 10 horas de descarte (D1 a D10) - Junho/2004. 106

FIGURA 39 - Gráfico ternário correlacionando os elementos $\mathrm{Ca}, \mathrm{Mg}$ e $\mathrm{Mn}$ presentes na fração solúvel do despejo, nas primeiras 10 horas de descarte - Julho/2004. 106

FIGURA 40 - Gráfico ternário correlacionando os elementos $\mathrm{Ca}, \mathrm{Mg}$ e $\mathrm{Mn}$ no rio Ribeira de Iguape (composição média no período de estudo), no ponto de captação da ETA, no periodo de Dezembro/2003 a Agosto/2004, para um total de nove amostras.

FIGURA 41 - Avaliação do teor de sólidos totais no córrego receptor até seis horas (D1 a D6) do início do descarte da ETA. 109

FIGURA 42 - Seqüência de gráficos resultantes da avaliação da propagação do despejo da ETA no curso d'água receptor, em função da análise de elementos majoritários encontrados.

FIGURA 43 - Avaliação da propagação do despejo da ETA no curso d'água receptor, em razão da análise dos elementos majoritários encontrados. 
FIGURA 44 - Avaliação da propagação do despejo da ETA no curso d'água receptor, em função da análise de manganês

FIGURA 45 - Elementos majoritários em águas superficiais.

FIGURA 46 - Determinação de Fe solúvel em águas superficiais.

FIGURA 47 - Concentrações de elementos traços em amostras de águas superficiais. ....117

FIGURA 48 - Teor de alumínio em águas superficiais, em 1 dia após descarte do lodo...119

FIGURA 49 - Porcentagem de resultados não conformes com a Classe 2

FIGURA 50 - Box plots dos parâmetros medidos em 1 dia após descarte do lodo.

FIGURA 51 - Box plots do teor de sólidos (totais, fixos e voláteis) medidos em 1 dia após descarte do lodo. 123

FIGURA 52 - Dendogramas representando a correlação entre pontos de coleta, por período de amostragem, a partir dos parâmetros utilizados na avaliação: oxigênio dissolvido, turbidez, alcalinidade, dureza, sólidos totais, sólidos totais fixos e sólidos totais voláteis. 124

FIGURA 53 - Dendogramas representando a correlação entre pontos de coleta, por período de amostragem, a partir dos parâmetros utilizados na avaliação: oxigênio dissolvido, turbidez, alcalinidade, dureza, sólidos totais, sólidos totais fixos e sólidos totais voláteis. 125

FIGURA 54 - Distribuição de alumínio nos pontos de coleta a montante (P1) e jusante (P2) do descarte do lodo da ETA. 
FIGURA 55 - Concentração de alumínio lixiviado em amostras de sedimento, conforme o indice pluviométrico e período de coleta. 132

FIGURA 56 - Correlação do teor de alumínio encontrado nas amostras de sedimento com a quantidade de coagulante adicionado pela ETA. 133

FIGURA 57 - Dendograma de discordância dos organismos bentônicos presentes no sedimento de fundo nos pontos de coleta P1 a P6 138

FIGURA 58 - Processos alternativos para o gerenciamento de lodo de ETAs. 139 


\section{LISTA DE ABREVIATURAS}

ABNT: Associação Brasileira de Normas Técnicas.

AAB: Adutora de Água Bruta.

AAS: Atomic Absorption Spectrometric - Espectrometria de absorção atômica.

CCME: Canadian Council of Ministers of the Environment.

CETESB: Companhia de Tecnologia de Saneamento Básico do Estado de São Paulo.

CIIAGRO: Centro Integrado de Informação Agrometeorológica.

CNEN: Comissão Nacional de Energia Nuclear.

CQMA: Centro de Química e Meio Ambiente.

CONAMA: Conselho Nacional do Meio Ambiente.

DAEE: Departamento de Ȧgua e Energia Elétrica.

DBO: Demanda Bioquímica de Oxigênio.

DQO: Demanda Quimica de Oxigênio.

DRX: Difração de Raios X.

EEAB: Estação Elevatória de Água Bruta. 
EEAT: Estação Elevatória de Ảgua Tratada.

ETA: Estação de Tratamento de Água.

ETE: Estação de Tratamento de Esgotos.

EPA: Environmental Protection Agency - Agência de Proteção Ambiental.

FAPESP: Fundação para o Amparo da Pesquisa no Estado de São Paulo.

FRX : Fluorescência de Raios X.

GPS: Global Positioning System - Sistema de Posição Global.

IAP: Índice de Abastecimento Pủblico.

IBGE: Instituto Brasileiro de Geografia e Estatística.

ICP-OES: Inductively Coupled Plasma Optical Emission Spectrometric - Espectrometria de Emissão Óptica com Plasma de Argônio.

IET: Índice do Estado Trófico.

IPEN: Instituto de Pesquisas Energéticas e Nucleares.

IPMCA: Índice de Parâmetros Mínimos para a Preservação da Vida Aquática.

IVA: Índice da Vida Aquática.

JCPDS: Joint Commitee of Powder Diffraction Standards. 
MEV: Microscopia Eletrônica de Varredura.

NBR: Normas Brasileiras (ABNT).

NIST: National Institute of Standards \& Technology - Instituto Nacional de Padrões \& Tecnologia (E.U.A).

OPAS: Organização Pan-Americana de Saúde.

PEL: Probable Effect Level - de acordo com CCME, descreve concentrações acima das quais são esperados efeitos adversos severos sobre organismos aquáticos.

PLANASA: Plano Nacional de Saneamento.

PNSB: Pesquisa Nacional de Saneamento Básico.

PROSAB: Programa de Pesquisa em Saneamento Básico.

RMSP: Região Metropolitana de São Paulo.

RPM: Rotação por minuto.

SABESP: Companhia de Saneamento Básico do Estado de São Paulo.

SRM: Standard Reference Material - Material de Referência Padrão.

TEL: Threshold Effect Level - de acordo com CCME, representa a concentração abaixo da qual não são esperados efeitos adversos sobre organismos aquáticos.

UGRHI: Unidade de Gerenciamento de Recursos Hídricos. 


\section{INTRODUÇÃO}

A preocupação com os recursos hídricos e sua importância para a qualidade de vida tem crescido em todo o mundo. Apesar de possuírem na natureza um ciclo equilibrado de renovação e sustentação, sem qualquer intervenção humana, as perspectivas atuais de uso e qualidade dos recursos hídricos para um futuro próximo são preocupantes, especialmente em razão da falta de equilíbrio entre a necessidade de consumo e a compreensão dos fenômenos naturais. Há cerca de 2.000 anos, a população mundial correspondia a $3 \%$ da população atual, enquanto o volume de água permanece o mesmo. A partir de 1950, o consumo de água triplicou em todo o mundo e o consumo de água por habitante aumentou em 50\% (CETESB, 2005). Muitos países têm enfrentado desafios em relação aos recursos d'água disponiveis, cujo problema também se relaciona com a perda da biodiversidade e desmatamento das florestas.

Historicamente, o homem tem se aproveitado dos recursos naturais que o nosso planeta oferece, levado pela necessidade natural da evolução de seu conhecimento. Por se tratar de ambiente propicio para o estabelecimento de cidades em todo o seu entorno, é nas bacias hidrográficas onde ocorrem os maiores impactos ambientais decorrentes das mais diversas atividades humanas. Os rejeitos produzidos pela população e pelas atividades comerciais e industriais desenvolvidas terminam interagindo com os recursos aquáticos, contaminando de forma rápida e fácil os recursos hídricos disponíveis e comprometendo a qualidade da água. Em decorrência do crescimento intenso da população mundial, a necessidade de fontes de água que atendam o suprimento para abastecimento da população, irrigação e geração de energia elétrica tem aumentado drasticamente. A evolução tecnológica verificada ao longo dos tempos vem acompanhando o aumento da população e sua demanda por variedades e facilidades de processos e produtos, refletindo diretamente no meio ambiente e provocando crescente escassez e conseqüente degradação dos recursos naturais. Em situações como estas, cabe sempre em primeiro lugar a identificação imediata dos problemas e das prioridades sociais, econômicas e ambientais, de forma a se decidir melhor quais ações deverão ser tomadas, garantindo-se um desenvolvimento econômico que evolua favoravelmente à manutenção das condições do meio ambiente (FGV, 2000). 
Após séculos de uma relação de máximo usufruto e de pouca atenção com a deterioração dos recursos ambientais, percebeu-se que a garantia de que os mananciais atualmente disponíveis forneçam água limpa e segura para as futuras gerações é fator da maior relevância para todos. $\mathrm{O}$ gerenciamento adequado dos recursos hídricos é cada vez mais condição essencial para um crescimento estruturado, visando até a minimização da pobreza. A ocupação de áreas degradadas por populações menos favorecidas é uma realidade, cuja melhoria na qualidade de vida está necessariamente associada à recuperação destas áreas. Desse modo, os recursos hídricos devem ser manipulados de forma sustentável e tratados (de acordo com sua própria definição) como mercadoria de valor econômico agregado, propiciando a captação de investimentos de forma mais oportuna para os mais diferentes projetos de infra-estrutura, em virtude de seu impacto benéfico nos âmbitos social e ambiental.

Um maior número de projetos para gerenciamento dos recursos hídricos pode oferecer bases para um desenvolvimento regional integrado, com benefícios diretos para a diminuição da pobreza. $\mathrm{Na}$ Índia, por exemplo, apenas $26 \%$ das pessoas que vivem em distritos beneficiados por projetos dessa natureza são pobres, em contraste com $69 \%$ daquelas que vivem em distritos carentes desses projetos (World Bank, 2004). Portanto, projetos de infra-estrutura de recursos hídricos também devem ser vistos como projetos de inclusão social. Por outro lado, o uso estratégico e mais racional dos recursos hídricos pode também representar uma economia nos investimentos realizados em situações circunstancialmente emergenciais e sob condições eminentes de riscos sanitários para a população, como nos casos de poluição de bacias hidrográficas próximas de grandes centros urbanos.

O Brasil possui grandes extensões de matas naturais, além da maior reserva de água doce disponível no mundo ( $8 \%$ do total), com uma responsabilidade redobrada na gestão desses recursos, promovendo ações de desenvolvimento sustentável que notoriamente envolvam e garantam as diferentes dimensões de nossa sociedade, sejam de aspectos ecológicos, sociais, culturais, econômicos, políticos e institucionais. Do total de reservas de água doce em nosso pais, cerca de $80 \%$ encontram-se na Amazônia. Os 20\% restantes distribuem-se nas demais regiões do país, onde está a maioria da população brasileira (CETESB, 2004). 
Apesar da existência de normas legais como o Código Florestal (Lei 4.771, de 1509-1965), a Lei de Parcelamento do Solo Urbano (Lei 6.766, de 19-12-1979) e dos artigos da Lei 6.766, que restringem a ocupação de encostas e de margens de rios, as regiões Sul e Sudeste, onde vivem $60 \%$ da população do país, passaram a enfrentar uma crescente ameaça de escassez de água. O processo de crescimento econômico do Brasil iniciado a partir da década de 50 propiciou um desenvolvimento mais rápido das cidades do que o campo, incentivando um fluxo migratório, especialmente para a região sudeste. Se naquele periodo, cerca de $70 \%$ da população ainda vivia no campo, ao fím da década de 80 a situação se inverteu, com $70 \%$ da população vivendo nas cidades. Tal crescimento ocorreu de forma desordenada, provocando a deterioração do meio ambiente nas regiões metropolitanas a partir da década de 70, agravado pela ausência do poder público no controle da poluição e de uma legislação ambiental eficiente. $O$ aumento da população demandou a implantação de políticas governamentais para o setor de saneamento básico, propiciando uma infra-estrutura necessária para a melhoria de vida da população, como estações de tratamento de água (ETAs) e esgotos (ETEs), represas, comportas de navegação, etc.

A indústria da água de abastecimento, quando utiliza o tratamento completo ou convencional (coagulação, floculação, decantação e filtração), transforma a água inadequada para consumo humano em um produto que esteja de acordo com o padrão de potabilidade (Portaria 518/04 MS), utilizando para isso, processos e operações como a introdução de produtos químicos, gerando resíduos. Estes têm origem nos decantadores, na lavagem dos filtros e na lavagem dos tanques de preparação de soluções e suspensões de produtos químicos. De acordo com o Programa de Pesquisa em Saneamento Básico (PROSAB, 1999), pouco tem sido realizado no Brasil sobre o assunto, e vários questionamentos têm sido feitos com relação às características, produção e impactos ambientais desses residuos gerados na bacia e quais alternativas possibilitariam o desenvolvimento sustentável do setor com descarte adequado. Existe uma carência de pesquisas e de desenvolvimento tecnológico no setor. Analisando-se a literatura nacional, nota-se que no Brasil existe pouca experiência em relação aos resíduos gerados em decantadores de estações de tratamento de água, principalmente em cidades de pequeno porte. Os principais trabalhos internacionais foram realizados pela Fundação de Pesquisa American Water Works Association (Cordeiro, 1993; AWWA, 1995). 
As estratégias de descarte adequado envolvem diversas opções e técnicas cujas pertinências são grandemente influenciadas, dentre outros fatores, pelas características dos lodos, da área disponível, da qualidade da bacia superficial de captação de água, do clima local e das condições socioeconômicas, culturais e ambientais da região. Dentre as várias alternativas encontradas na literatura para disposição final do lodo de ETA's podemos citar: disposição em cursos d'água; disposição em aterros sanitários; disposição em aterros exclusivos; gerenciamento conjunto com lodo de tratamento de esgoto e co-disposição com biosólido; aplicação controlada em certos tipo de solo; aplicações industriais diversas (na industria cerâmica, incorporação em materiais da construção civil); regeneração do coagulante, entre outras (Reali, 1998; Murray \& Dillon, 1994; Tumeo, 1992; Gonçalves et a.l 1999; Dharmappa, 1997).

Nos últimos cinco anos, a CETESB - Companhia de Tecnologia de Saneamento Básico do Estado de São Paulo, tem intensificado a fiscalização sobre o lançamento de lodos gerados em ETAs em corpos d'água, o que tem exigido das concessionárias de saneamento a busca de alternativas para a solução desse problema. A SABESP Companhia de Saneamento Básico do Estado de São Paulo, vem realizando estudos visando a viabilização de alguns destes usos benéficos do lodo gerado em suas ETAs, tais como a incorporação na fabricação de cerâmica vermelha (tijolos, telhas e manilhas) e incorporação na selagem de células de aterro sanitário, obtendo resultados bastante promissores (SABESP, 2005).

De acordo com as informações fornecidas pelas áreas operacionais, são produzidos aproximadamente 160 t/dia de lodo de ETA, com a produção da RMSP estimada em 91,5 t/dia (SABESP, 2003). Por intermédio da Diretoria de Sistemas Regionais (DSR), a SABESP opera 175 ETAs, cuja maioria ainda tem lançado os lodos diretamente nos córregos e rios próximos às estações, sofrendo autuações dos órgãos de controle ambiental e ações por parte do Ministério Público. Desse universo, a SABESP trata o lodo da ETA de Taiaçupeba na Região Metropolitana de São Paulo (RMSP) e das ETAs de Cubatão e Franco da Rocha. O lodo da ETA Franca é lançado no coletor tronco e encaminhado à ETE, onde é feito o tratamento para posterior disposição na agricultura (SABESP, 2005). 
O tratamento e disposição final desses lodos vêm se tornando uma meta crucial no processo de gerenciamento das ETAs, consumindo uma significativa parcela orçamentária da produção de água para abastecimento público. Por outro lado, também tem sofrido grandes pressões ambientais tanto em sistemas de grande porte, como em sistemas de pequeno porte.

Uma alternativa que se tem mostrado viável, tanto do ponto vista técnico quanto econômico, é o lançamento do lodo em rede coletora de esgoto para posterior tratamento na ETE. Entretanto, essa alternativa só é possível quando o sistema de coleta, transporte e tratamento de esgoto estiver trabalhando com folga operacional para absorver a vazão/carga adicional decorrente do lançamento. Além disso, a rede deverá apresentar declividade suficiente para arrastar os sólidos presentes no lodo. Cabe lembrar que as propostas apresentadas servem apenas como um instrumento na fase de planejamento. Já nas etapas seguintes, deverão ser observadas as particularidades inerentes a cada estação.

Nas cidades de pequeno porte, normalmente os sistemas de tratamento de esgotos implantados são de lagoas de estabilização. Estes sistemas caracterizam-se por utilizar grandes áreas de implantação e possuir um tempo de detenção hidráulico bem longo (em torno de 20 dias). Para estes sistemas de pequeno e médio porte, pode-se adotar como alternativa de tratamento a transferência do lodo de ETA para as lagoas de estabilização. A vantagem deste tipo de solução seria a concentração dos problemas referentes a lodo para uma única localização, o que absorveria os custos operacionais e de investimentos necessários para a realização de retirada, tratamento e disposição final. $O$ gerenciamento dos lodos das ETEs e sua disposição controlada no solo são práticas atualmente bem estabelecidas e estudadas pelo setor de pesquisa e de saneamento (PROSAB, 1999).

O lodo gerado pelas ETAs tem características distintas e bastante variadas, dependendo das condições apresentadas pela água bruta, dosagem e produtos químicos utilizados, além da forma de limpeza dos decantadores. O lodo é também denominado de lodo quimico, por ser constituido por materiais inertes (Kawamura, 1991). Os processos de clarificação da água (coagulação/floculação/sedimentação) removem cor e turbidez da água bruta, além da matéria orgânica presente. 
A maioria das estações de tratamento de água emprega o sulfato de aluminio como coagulante, ocasionando a identificação do lodo que geram como sendo lodo de alumínio. A sua natureza gelatinosa, sólida em repouso e líquida quando agitada, dificulta a sua secagem, razão pelas quais várias tentativas de solução para o mesmo têm sido experimentadas. Destacam-se, entre elas, aquelas que contemplam unidades de adensamento e condicionamento, de desidratação (tipo leitos de secagem), lagoas de lodo, filtros a vácuo, filtros-prensa, centrífugas, etc. Devemos observar que o aluminio sofre restrições de emissão de acordo com a Legislação Ambiental Brasileira, com limites em águas superficiais de $0,1 \mathrm{mg} . \mathrm{L}^{-1}$ (CONAMA 357, 2005).

Uma avaliação preliminar da concentração de metais presentes na fase sólida nos lodos de ETAs permitiu perceber que a concentração de metais predomina na fase sólida do lodo e que existe a necessidade de se equacionar o problema quase de forma individualizada. No Brasil, é insuficiente o estudo sobre o impacto e a toxicidade desses resíduos na bacia, além da influência da aplicabilidade dos produtos químicos no entorno da bacia (PROSAB, 1999).

Um dos grandes problemas é a falta de conhecimento sobre as características dos sólidos presentes no lodo, tamanho e distribuição das partículas, resistência específica, impurezas, metais predominantes, estabilidade desses metais na formação final do lodo e toxicidade ao meio aquático. A disposição desses resíduos pode causar alterações consideráveis no corpo d'água receptor e conseqüentemente na bacia hidrográfica. Os fatores químicos, biológicos e físicos que alteram as condições ambientais podem causar enfermidades ecológicas, agindo de maneira a interferir negativamente no meio ambiente, como é o caso do alumínio, além de inferir em problemas quanto à legislação ambiental vigente.

Para o desenvolvimento deste estudo, elegeram-se as estações de tratamento de água localizadas na Bacia do Rio Ribeira de Iguape, na Unidade de Gerenciamento de Recursos Hídricos (UGRHI) 11. Sua escolha se deu em virtude da bacia de drenagem apresentar grande disponibilidade de água, diante da pequena demanda, quando comparada a outras. 
A área possui um histórico alarmante quanto à contaminação de chumbo, além de ser detentora do mais importante e principal potencial mineral do Estado de São Paulo, com grande variedade de substâncias minerais desde ferrosos, metálicos e preciosos, além de minerais raros como prata, antimônio e terras raras. Todo esse contexto se reflete nas características geoquímicas da água, do sedimento de drenagem, do material em suspensão e conseqüentemente na qualidade dos lodos gerados nas ETAs (Pires et al., 2003, 2002; Nogueira et al., 2003).

Este projeto tem por prioridade ampliar o conhecimento no setor de saneamento com relação ao gerenciamento de lodos de ETAs em cidades de pequeno e médio porte. A abordagem integrada das ações dentro do tema pretende disseminar a informação, promover a capacitação permanente das instituições, padronizar metodologias de análise e realizar uma revisão do padrão tecnológico atual aplicado. Os resultados permitirão obter subsídios técnicos para a avaliação, recuperação e entendimento de ecossistemas aquáticos, de forma a auxiliar na tomada de decisão para o gerenciamento do lodo, favorecendo a atuação da política estadual de recursos hídricos.

No contexto de política estadual de controle da qualidade da água das bacias hidrográficas este projeto também fornece subsídios ao projeto FAPESP 03/01694-1: "Gerenciamento de Lodos de ETAs. Influência do lançamento do lodo de ETA no processo de tratamento de esgotos por lagoas de estabilização em cidades de pequeno/médio porte", realizado em parceria com a SABESP e com a Escola Politécnica da Universidade de São Paulo (Poli/USP). 


\section{OBJETIVOS}

\subsection{Objetivo geral}

O principal objetivo deste trabalho foi realizar uma análise sistêmica da ETA de Registro, da SABESP, quanto à caracterização, tratamento e disposição dos resíduos gerados em estações de tratamento de água de ciclo completo com decantadores do tipo convencional e sua correlação com a qualidade do meio hidrico, na bacia hidrográfica do rio Ribeira de Iguape.

\subsection{Objetivos específicos}

1. Caracterizar o sistema de tratamento de água de uma cidade de porte médio (SABESP/Registro/SP), por meio de avaliação física, química e operacional quanto à qualidade da água bruta e nas diversas etapas de tratamento, insumos e do descarte dos resíduos gerados no periodo de 2003-2004;

2. Avaliar as principais características dos resíduos gerados por uma ETA e os efeitos físico-químicos de seu descarte na qualidade da água e sedimento da Bacia Hidrográfica do rio Ribeira de Iguape, utilizando como critérios a Portaria 518/04/MS e o CONAMA $357 / 05$, ampliando as informações existentes voltadas para o cenário regional fundamentado no uso múltiplo e na sustentabilidade dos recursos naturais;

3. Avaliar soluções especificas ao problema de descarte dos despejos de uma ETA, de modo a atender aos padrões ambientais estabelecidos e sem causar prejuizos à qualidade ambiental no entorno da ETA e no rio Ribeira de Iguape, intensificando as relações entre a sociedade, instituições de pesquisa e o setor de saneamento, beneficiando a implantação de políticas públicas. 


\section{CONSIDERAÇÕES GERAIS}

\subsection{Revisão bibliográfica}

As políticas governamentais para o setor de saneamento básico, sobretudo até a década de 1960, foram caracterizadas por medidas esporádicas e localizadas. No entanto, em meados da década de 70, o governo federal criou o Plano Nacional de Saneamento (PLANASA), com o objetivo de criar companhias estaduais de saneamento que operassem serviços de tratamento e fornecimento de água, além da coleta e tratamento de efluentes, eliminando o déficit do abastecimento de água e do esgotamento sanitário (IBGE, 2002).

Ao mesmo tempo, realizou-se em 1974 o primeiro levantamento nacional sobre saneamento básico no Brasil, mediante um convênio celebrado entre o Ministério da Saúde e o Instituto Brasileiro de Geografia e Estatística (IBGE). A partir desta data, novos levantamentos foram realizados, criando-se, no primeiro semestre de 2000 , a Pesquisa Nacional de Saneamento Básico 2000, PNSB, que contou, também, com a colaboração da Organização Pan-americana de Saúde, OPAS, para o planejamento e execução da pesquisa. A PNSB/2000 foi mais abrangente, incorporando novas variáveis aos temas já pesquisados em um levantamento realizado em 1989 (IBGE, 2002).

A reformulação foi feita a partir da experiência adquirida com a PNSB/1989, com a finalidade de atender a maioria das demandas feitas por órgãos e técnicos envolvidos com o tema da pesquisa. A reformulação decorreu também das transformações ocorridas no setor ao longo dos anos, procurando preencher lacunas verificadas na pesquisa anterior (IBGE, 2002). Comparando-se os dados da PNSB de 1989 com os de 2000, pode-se constatar a evolução da cobertura do serviço de abastecimento de água. De acordo com o IBGE (2002), se no ano de 1989 o Brasil tinha seu território dividido em 4.425 municípios, onde $\mathbf{9 5 , 9 \%}$ dos quais contavam com serviço de abastecimento de água por rede geral, em 2000 o número foi aumentado para 5.507 municípios. A rede de abastecimento foi ampliada, com o atendimento por empresas prestadoras deste serviço alcançando uma proporção significativa de $97,9 \%$ dos municípios do país (TAB.1). 
TABELA 1 - Municípios, total e com serviço de abastecimento de água, segundo as Grandes Regiões - 1989-2000.

\begin{tabular}{|c|c|c|c|c|c|c|}
\hline \multirow{4}{*}{$\begin{array}{l}\text { Grandes } \\
\text { Regiões }\end{array}$} & \multicolumn{6}{|c|}{ Municipios } \\
\hline & \multicolumn{3}{|c|}{1989} & \multicolumn{3}{|c|}{2000} \\
\hline & \multirow[b]{2}{*}{ Total } & \multicolumn{2}{|c|}{$\begin{array}{c}\text { Com serviço de } \\
\text { abastecimento de água }\end{array}$} & \multirow[b]{2}{*}{ Total } & \multicolumn{2}{|c|}{$\begin{array}{c}\text { Com serviço de } \\
\text { abastecimento de água }\end{array}$} \\
\hline & & Total & $\begin{array}{c}\text { Percentual } \\
\text { (\%) }\end{array}$ & & Total & $\begin{array}{c}\text { Percentual } \\
\text { (\%) }\end{array}$ \\
\hline Brasil & 4425 & 4245 & 95,9 & 5507 & 5391 & 97,9 \\
\hline Norte & 298 & 259 & 86,9 & 449 & 422 & 94,0 \\
\hline Nordeste & 1461 & 1371 & 93,8 & 1787 & $\overline{1722}$ & 96,4 \\
\hline Sudeste & 1430 & 1429 & 99,9 & 1666 & 1666 & 100,0 \\
\hline Sul & 857 & 834 & 97,3 & 1159 & 1142 & 98,5 \\
\hline $\begin{array}{l}\text { Centro- } \\
\text { Oeste }\end{array}$ & 379 & 352 & 92,9 & 446 & 439 & 98,4 \\
\hline
\end{tabular}

Fonte: IBGE, Diretoria de Pesquisas, Departamento de População e Indicadores Sociais, Pesquisa Nacional de Saneamento Básico 1989/2000.

Dentre os municípios avaliados no último censo com mais de $\mathbf{3 0 0 . 0 0 0 ~ h a b i t a n t e s , ~}$ um percentual de $85,7 \%$ possuem estações de tratamento que tratam de forma convencional o volume da água distribuída (IBGE, 2002). De acordo com o próprio IBGE, o tratamento convencional representa o tratamento da água bruta pelos processos de floculação, decantação, filtração, correção de pH, desinfecção (cloração) e fluoretação, antes de ser distribuída à população. Quando se considera o número total de distritos que possuem algum sistema de tratamento de água, percebe-se que em torno de $50 \%$ dos municípios brasileiros possuem sistemas de tratamento do tipo convencional, que geram resíduos insolúveis originados pelo processo de tratamento (TAB.2), e que não operam sob um programa de recuperação e tratamento dos resíduos gerados.

Considerando-se o destino dado ao lodo gerado, conforme demonstrado na TAB.3, constata-se que aproximadamente $90 \%$ dos distritos que passam por coagulação química dispõem seus resíduos insolúveis no meio ambiente (rio, mar e terreno) sem quaisquer preocupações com seu tratamento e recuperação, apesar de algumas de suas propriedades, como seu aspecto gelatinoso e volumoso, resultante da presença de grandes concentrações de hidróxidos metálicos combinada com uma baixa concentração de sólidos (IBGE, 2002). 
TABELA 2 - Número de distritos brasileiros abastecidos com sistemas de tratamento de água, por tipo de tratamento -2000 .

\begin{tabular}{|c|c|c|c|c|c|c|c|}
\hline \multirow{3}{*}{$\begin{array}{c}\text { Total de } \\
\text { Distritos } \\
\text { do } \\
\text { Brasil }\end{array}$} & \multicolumn{7}{|c|}{ Distritos abastecidos com tratamento de água } \\
\hline & \multirow[b]{2}{*}{ Total } & \multicolumn{4}{|c|}{ Tipo de Tratamento } & \multirow[b]{2}{*}{ Fluoretação } & \multirow{2}{*}{$\begin{array}{c}\text { Sem } \\
\text { tratamento }\end{array}$} \\
\hline & & Total & Convencional & $\begin{array}{c}\text { Não- } \\
\text { convencional }\end{array}$ & $\begin{array}{c}\text { Simples } \\
\text { desinfecção }\end{array}$ & & \\
\hline 9.848 & 8.656 & 6.046 & 3.413 & 675 & 2.630 & 3.202 & 3.258 \\
\hline
\end{tabular}

Fonte: IBGE, Diretoria de Pesquisas, Departamento de População e Indicadores Sociais, Pesquisa Nacional de Saneamento Básico 1989/2000.

TABELA 3 - Número de distritos brasileiros cuja água tratada passa por processo de coagulação química, por destino do lodo gerado -2000 .

\begin{tabular}{|c|c|c|c|c|c|c|c|c|}
\hline \multirow{3}{*}{$\begin{array}{l}\text { Total de } \\
\text { distritos } \\
\text { do } \\
\text { Brasil }\end{array}$} & \multicolumn{8}{|c|}{ Distritos cuja água tratada passa por processo de coagulação química } \\
\hline & \multirow[b]{2}{*}{ Total } & \multicolumn{7}{|c|}{ Destino do lodo gerado } \\
\hline & & Rio & Mar & Terreno & $\begin{array}{c}\text { Aterro } \\
\text { Sanitário }\end{array}$ & Incineração & $\begin{array}{c}\text { Reaprovei } \\
\text { tamento }\end{array}$ & Outro \\
\hline 9.848 & 2.593 & 1.888 & 10 & 482 & 35 & 2 & 39 & 189 \\
\hline
\end{tabular}

Fonte: IBGE, Diretoria de Pesquisas, Departamento de População e Indicadores Sociais, Pesquisa Nacional de Saneamento Básico 1989/2000.

Esse processo de descarte pode alterar consideravelmente as características das águas do corpo receptor, provocando o assoreamento e mudança na cor, turbidez e composição quimica da água, além da possibilidade de contaminação do lençol freático (PROSAB, 1999).

A possibilidade da presença de metais tóxicos em descartes de lodos de ETA é preocupante, pois seu descarte indiscriminado no local próximo ao despejo no próprio corpo d'água, pode danificar ou inibir qualquer atividade biológica existente, em virtude da grande variedade de acesso aos componentes biológicos como órgãos, tecidos, células e moléculas. Além disso, todos os sistemas enzimáticos são potencialmente suscetíveis aos metais tóxicos que, num organismo vivo, podem ter sua entrada limitada pelas estruturas anatômicas. Isto explica as consideráveis diferenças de sensibilidade entre diferentes órgãos e tecidos, na ação observada entre experimentos in vivo e in vitro, entre espécies e em certas respostas típicas para envenenamento clínico (Moreira, 2004). 
Portanto, não existe ainda uma clara compreensão do impacto resultante da degradação dos cursos d'água receptores, seja em relação a consequiências em curto prazo, seja em longo prazo, em que se considere a influência ou mesmo a perda de ecossistemas e acumulação de toxinas (Moreira, 2004). Se considerarmos que milhões de toneladas desses resíduos são dispostos anualmente no ambiente, especialmente pelo fato da maioria das ETAs não possuírem instalações específicas para a disposição desses resíduos, então podemos classificar os lodos formados como um importante problema ambiental das ETAs, na forma de subprodutos com potencial poluidor, devido aos seus efeitos químicos, físicos e biológicos (AWWA, 1974; Lester, 1987; Cordeiro, 1993; Sotomayor, 1999; PROSAB, 1999; Carvalho, 2000). Na FIG.1, pode-se observar o impacto visual imediato do descarte de lodo, em um córrego próximo a uma ETA.

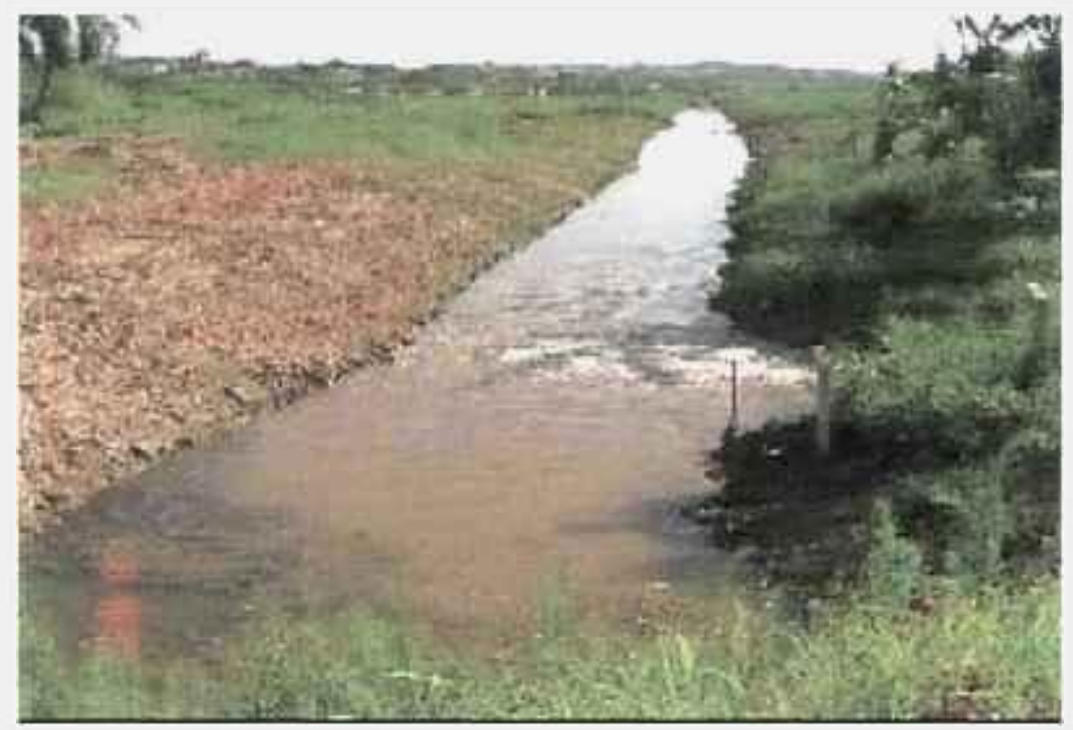

FIGURA 1 - Despejo de lodo de ETA de Registro em um curso d'água.

Uma avaliação preliminar da concentração de metais presentes na fase sólida nos lodos de ETAs situados no Estado de São Paulo permitiu perceber que a concentração de metais predomina de maneira sensível e que existe a necessidade de se equacionar o problema (PROSAB, 1999). Nesse sentido, o gerenciamento adequado dos sistemas de tratamento de águas para o abastecimento público deve atender não só ao produto final como também equacionar todos os problemas relacionados à proteção efetiva dos mananciais, qualidade dos produtos químicos empregados e quantidade e características dos resíduos gerados. 
Se por um lado, os órgãos públicos de meio ambiente impõem rigorosos padrões de emissão de poluentes, por outro lado, empresas de saneamento necessitam de um prazo para adequação e regularização de seus efluentes, bem como o de aplicar e desenvolver tecnologias adequadas para o gerenciamento das ETAs. Apesar da evidência do ônus que tal situação representa para o meio ambiente, são poucas as referências encontradas sobre o assunto, especificamente relacionadas à ambientes tropicais, como no caso do Brasil.

Tumeo (1992) realizou um estudo da influência do despejo do lodo da ETA em um rio em um ambiente ártico, porém sujeito à sazonalidade do degelo da região, não encontrando naquelas condições quaisquer evidências contundentes de contaminação, não só em relação aos metais analisados, mas também em relação aos bentônicos considerados.

Kaggwa (2001) estudou os efeitos do despejo do lodo de ETA em ambiente tropical, com indicações de um impacto negativo do descarte do lodo no ecossistema estudado, especialmente quando considerados em longo prazo. Cordeiro (1993) concluiu em um estudo dos despejos da ETA de São Carlos (SP), que parâmetros como sólidos sedimentáveis e metais como chumbo, cobre e niquel, mostraram-se em níveis superiores aos estabelecidos pela legislação ambiental vigente.

Barroso (2002) observou que durante o processo de lavagem dos decantadores, diversas variáveis analisadas também transgrediram a legislação, com exceção do pH. No mesmo estudo, a água de lavagem dos filtros apresentou níveis de $\mathrm{Al}$ e $\mathrm{Fe}$ que se mostraram superiores a Resolução CONAMA 20/86, além da presença de $\mathrm{Pb}$ e $\mathrm{Ni}$ em concentrações acima do permitido pela legislação estadual. Guerra \& Angelis (2005) concluíram que o lodo da ETA necessita de condições adequadas para a sua disposição final.

Pode-se observar que nos paises desenvolvidos (TAB.4) o lançamento do lodo de ETA nos cursos d'água vem sendo drasticamente reduzido, como conseqüência de legislações mais rigorosas de controle da poluição, da crescente escassez dos recursos hídricos, captados cada vez mais distantes e a custos elevados, e também por causa do grande desperdício que representa descartar de 2 a $6 \%$ do volume de água produzido em uma ETA, gastos nas atividades de lavagens dos filtros e descargas de decantadores (Grandin, 1992). 
TABELA 4: Métodos de disposição final de lodo de ETA, em diferentes países (SABESP, 2003).

\begin{tabular}{|c|c|c|c|c|c|c|}
\hline \multirow{2}{*}{ PAÍS } & \multicolumn{6}{|c|}{ DISPOSIÇÃO FINAL DO LODO DE ETA } \\
\cline { 2 - 7 } & $\begin{array}{c}\text { Aterro } \\
\text { sanitário }\end{array}$ & $\begin{array}{c}\text { Aterro } \\
\text { Exclusivo }\end{array}$ & $\begin{array}{c}\text { Descarga } \\
\text { no SES(*) }\end{array}$ & $\begin{array}{c}\text { Descarga } \\
\text { em } \\
\text { córregos }\end{array}$ & $\begin{array}{c}\text { Aplicação } \\
\text { no solo }\end{array}$ & Outros \\
\hline EUA & $20 \%$ & $13 \%$ & $24 \%$ & $11 \%$ & $25 \%$ & $7 \%$ \\
\hline Alemanha & $19,4 \%$ & $0,3 \%$ & $38,9 \%$ & $13,4 \%$ & $6 \%$ & $22 \%$ \\
\hline França & $13 \%$ & - & $30 \%$ & ND $^{5}$ & $6 \%$ & $53 \%$ \\
\hline Reino Unido & $52 \%$ & $6 \%$ & $29 \%$ & $2 \%$ & ND $^{5}$ & $9 \%$ \\
\hline
\end{tabular}

*SES: Sistema de Esgotos

Alternativas para o destino final do lodo de ETAs têm sido propostas em diversos trabalhos, como a disposição em aterros sanitários, aterros exclusivos, gerenciamento conjunto com lodo de tratamento de esgoto e co-disposição com biosólido, aplicação controlada em certos tipos de solo e aplicações industriais diversas (PROSAB, 1999; Murray, 1994; Tumeo, 1992; Andreoli, 2001, Gonçalves et al. 1999; Dharmappa, 1997). Guerra \& Angelis (2005) verificaram a viabilidade de disposição do lodo de ETA em aterro sanitário, que não sofreu interferência de forma negativa no processo de biodegradação.

Oliveira e Assịs (2001) mostraram a possibilidade da reciclagem de entulhos da construção civil como possibilidade de destinação para o lodo de ETA. Richter (2001) propôs a incorporação em materiais de construção civil. Nuvolari (2002), Paixão (2004), Morita (2002), Knoblauch (2004), Miyahara (2004), Cosin (2004) e Hoppen (2003) realizaram estudos sobre a incorporação do lodo de ETA em materiais cerâmicos e na fábricação de cimento e tijolos.

O uso agrícola do lodo de uma ETA foi avaliado por Machado (2004), com possibilidade de recuperação de áreas degradadas pela ação antrópica. Propostas para minimização da geração do lodo foram apresentadas por Campos (2004), Parsekian (2004), Bresaola (2004), Gonçalves (1999), Fontana (2004) e Moraes (2004), sugerindo alternativas aos processos de tratamento de água convencionais. 
David (2004) propôs a redução do volume do lodo de ETA por secagem natural, visando sua utilização em aterros sanitários ou como matéria prima para a indústria cerâmica. A utilização do lodo em aterro exclusivo, no entanto, foi abordado por Siqueira (2004) que, segundo o autor, apresentou diversas vantagens técnicas, econômicas e ambientais como destino final para esses resíduos. Na TAB.5 enumeram-se alguns métodos que têm sido considerados para a disposição do lodo de ETA, baseando-se nos trabalhos já citados.

O que se percebe, portanto, é que estratégias de descarte adequado envolvem opções e técnicas distintas, cujas pertinências são grandemente influenciadas, dentre outros fatores, pelas características dos lodos, área disponível, qualidade da bacia superficial de captação de água, clima local e pelas condições sócio-econômicas, culturais e ambientais da região. Neste sentido, o fato de aproximadamente $74 \%$ dos municípios brasileiros possuírem menos de 20.000 habitantes, requer das empresas de saneamento soluções para o tratamento destes resíduos diferentes daquelas geralmente empregadas para áreas urbanas extensas, como é o caso das cidades de São Paulo e Rio de Janeiro (IBGE, 2002). De qualquer forma, apesar das diferentes formas de disposição propostas, ainda não temos uma solução definitiva para o destino do lodo de ETA que reúna características como simplicidade de operação, eficiência e custo reduzido.

Existe hoje a preocupação com as ETAs, de modo que a disposição do lodo produzido seja regulamentada conforme critérios ambientais estabelecidos para efluentes industriais. Um dos critérios estabelecidos é a norma NBR 10.004, que classifica os resíduos sólidos de acordo com os possíveis riscos à saúde pública conforme estabelecidos pela Associação Brasileira de Normas Técnicas (ABNT, 2004), atendendo o art. 54, Sec. III Lei 9.605/98, atividades lesivas ao meio ambiente. Com a promulgação da Constituição Federal de 1988, a questão dos resíduos sólidos por meio de artigos relacionados à saúde e ao meio ambiente passou a ser matéria constitucional. $O$ artigo 23 determina que seja competência comum da União, Estados, do Distrito Federal e dos Municípios protegerem o meio ambiente e combater a poluição em qualquer de suas formas; já no artigo 200 (incisos IV e VII) verifica-se que compete ao sistema único de saúde participar da formulação da política e da execução das ações de saneamento básico e colaborar na proteção do meio ambiente, entre outras atribuições. 
TABELA 5 - Vantagens e desvantagens de algumas alternativas para tratamento e disposição do lodo de ETA (Albrecht, 1972; Eckenfelder, 1981; PROSAB, 1999).

\begin{tabular}{|c|c|c|c|}
\hline & Alternativas & Vantagens & Desvantagens \\
\hline 1 & $\begin{array}{l}\text { Descarte do lodo da ETA em } \\
\text { rios e córregos. }\end{array}$ & $\begin{array}{l}\text { - Sem custo de tratamento do lodo para } \\
\text { a ETA. }\end{array}$ & $\begin{array}{l}\text { - Não reduz o impacto da prática de descarte do } \\
\text { lodo; } \\
\text { - Contrário à legislaçåo estadual e federal. }\end{array}$ \\
\hline 2 & $\begin{array}{l}\text { Descarte do lodo da ETA em } \\
\text { lagoa de decantação. }\end{array}$ & $\begin{array}{l}\text { - Operação simples e baixo custo de } \\
\text { manutenção; } \\
\text { - Nenhum impacto no sistema de } \\
\text { exgotos. }\end{array}$ & $\begin{array}{l}\text { - Alto custo de implantação; } \\
\text { - Requer uma área extensa para implantação; } \\
\text { - Ausência de disponibilidade de áreas a uma } \\
\text { distância razoável da ETA; } \\
\text { - Influência do clima; } \\
\text { - Proliferação de insetos; } \\
\text { - Necessidade de limpeza periódica. }\end{array}$ \\
\hline 3 & $\begin{array}{l}\text { Remoção continua do lodo } \\
\text { da ETA dos tanques de } \\
\text { decantação e transporte do } \\
\text { material removido para } \\
\text { aterros por caminhoes. }\end{array}$ & $\begin{array}{l}\text {-Todas as operaç̃es são executadas na } \\
\text { própria ETA; } \\
\text { - Elimina a limpeza dos tanques de } \\
\text { decantação; } \\
\text { - Elimina qualquer tipo de impacto no } \\
\text { sistema de esgotos; } \\
\text { - Concentra os sólidos para descarte. }\end{array}$ & $\begin{array}{l}\text { - Operaçāo complexa; } \\
\text { - Alto custo de operação e manutenção; } \\
\text { - Alto investimento; } \\
\text {-Aumenta trá fego de caminhões no entorno da } \\
\text { ETA. }\end{array}$ \\
\hline 4 & $\begin{array}{c}\text { Destinaçăo do lodo da ETA } \\
\text { para o sistema de esgotos } \\
\text { para tratamento posterior em } \\
\text { uma ETE }\end{array}$ & $\begin{array}{l}\text { - Operação relativamente simples; } \\
\text { - Baixo investimento e custos de } \\
\text { operação; } \\
\text { - Bombeamento controlado para o } \\
\text { sistema de esgotos para redução de } \\
\text { oscilações de fluxo do lodo. } \\
\text { - Não há interferência significativa no } \\
\text { desempenho dos digestores de lodo, de } \\
\text { acordo com alguns estudos de caso. }\end{array}$ & $\begin{array}{l}\text { - O descarte do lodo deverá ser otimizado para } \\
\text { minimizar o impacto hidráulico no sistema de } \\
\text { esgotos e na ETE; } \\
\text { - Aumenta o fluxo de material no sistema de } \\
\text { esgotos; } \\
\text { - Aumenta a carga de sólidos na ETE. }\end{array}$ \\
\hline 5 & $\begin{array}{c}\text { Reaproveitamento de } \\
\text { coagulantes de lodo no } \\
\text { processo de tratamento de } \\
\text { água }\end{array}$ & $\begin{array}{l}\text { - Reduçáo do volume de lodo } \\
\text { descartado: } \\
\text { - Reciclagem dos produtos químicos } \\
\text { utilizados durante o tratamento. }\end{array}$ & $\begin{array}{l}\text { - Aumento dos serviços de operação; } \\
\text { - Aumento de etapas ao processo de } \\
\text { tratamento; } \\
\text { - Consumo de produtos químicos. }\end{array}$ \\
\hline 6 & $\begin{array}{l}\text { Uso de leitos de secagem } \\
\text { para eliminação da água do } \\
\text { lodo da ETA }\end{array}$ & $\begin{array}{l}\text { - Remoção da quase totalidade dos } \\
\text { sólidos em suspensão, com } \\
\text { concentraçdes de sólidos de } 20 \% \text { ou } \\
\text { mais, permitindo o uso do lodo para } \\
\text { disposição em aterros. }\end{array}$ & $\begin{array}{l}\text { - Ausència de terrenos disponiveis para } \\
\text { secagem; } \\
\text { - Efeitos do clima, devido à temperatura e } \\
\text { umidade: } \\
\text { - Custos do manuseio do lodo seco para } \\
\text { disposição final. }\end{array}$ \\
\hline 7 & $\begin{array}{l}\text { Desidrataçăo do lodo por } \\
\text { centrifugaçăo }\end{array}$ & $\begin{array}{l}\text { - melhora a eficiência na desidratação do } \\
\text { lodo da ETA para disposição; } \\
\text { - Requer pouco espaço no processo de } \\
\text { tratamento; } \\
\text { - Processo automatizado. }\end{array}$ & $\begin{array}{l}\text { - Volume do lodo gerado a ser desidratado em } \\
\text { ETAs de grande porte; } \\
\text { - Elevado custo de manutenção. }\end{array}$ \\
\hline
\end{tabular}


A própria Lei de Crimes Ambientais (9.605/98) dispõe sobre as sanções penais e administrativas derivadas de condutas e atividades lesivas ao meio ambiente. Esta lei prevê em seu artigo 54 que é crime "causar poluição de qualquer natureza em níveis tais que resultem ou possam resultar em danos à saúde humana, ou que provoquem a mortandade de animais ou a destruição significativa da flora". O mesmo artigo, em seu parágrafo $2^{\circ}$, inciso $\mathrm{V}$, penaliza o lançamento de resíduos sólidos, líquidos ou gasosos, ou detritos, óleos ou substâncias oleosas, em desacordo com exigências estabelecidas em leis ou regulamentos.

Por outro lado, a Resolução CONAMA n . 357/05, em conformidade com a NBR $\mathrm{n}^{\circ}$. 10.004 da $\mathrm{ABNT}$, definiu os resíduos sólidos em seu artigo $1^{\circ}$ como aqueles "que resultam de atividades da comunidade de origem industrial, doméstica, hospitalar, comercial, agrícola, de serviços e de varrição". Encontram-se incluídos nesta definição, "os lodos provenientes de sistemas de tratamento de água, aqueles gerados em equipamentos e instalações de controle de poluição, bem como determinados líquidos cujas particularidades tornem inviável seu lançamento na rede pública de esgotos ou corpos d'água, ou exijam para isso soluções técnicas e economicamente inviáveis, em face à melhor tecnologia disponível".

Contudo, a legislação que regula a matéria é fragmentada, o que dificulta sua compreensão e aplicação, conforme é descrito na TAB. 6. Suas normas estão distribuídas em legislações federais, estaduais e municipais específicas, além de possuírem dispositivos e resoluções de organismos de todas as esferas do governo, como é o caso da CETESB, ligada ao governo do Estado de São Paulo, e do Conselho Nacional do Meio Ambiente (CONAMA).

De acordo com a norma, os resíduos podem ser classificados em:
a) resíduos classe I - Perigosos;
b) resíduos classe II - Não perigosos;
- resíduos classe II $A$ - Não inertes.
- resíduos classe II B - Inertes. 
TABELA 6 - Regulamentos no âmbito federal e estadual que regem sobre a importância do gerenciamento da quantidade e da qualidade dos recursos hídricos.

\begin{tabular}{|c|c|c|}
\hline Lei & Ȧmbito & Atribuição \\
\hline Lei $7.663 / 91$ & $\begin{array}{c}\text { Estadual } \\
\text { (SP) }\end{array}$ & Institui a Política Estadual de Recursos Hídricos; \\
\hline Lei $9.433 / 97$ & Federal & $\begin{array}{l}\text { Institui a Política Nacional de Recursos Hídricos, cria o Sistema } \\
\text { Nacional de Gerenciamento de Recursos Hídricos, regulamenta o } \\
\text { inciso XIX do art. } 21 \text { da Constituição Federal, e altera o art. } 1^{\circ} \\
\text { da Lei } 8.001 \text {, de } 13 \text { de março de } 1990 \text {, que modificou a Lei } \\
7.990 \text {, de } 28 \text { de dezembro de } 1989 \text {; }\end{array}$ \\
\hline Lei $9.866 / 97$ & $\begin{array}{c}\text { Estadual } \\
\text { (SP) }\end{array}$ & $\begin{array}{l}\text { Dispõe sobre diretrizes e normas para a proteção e recuperação } \\
\text { das bacias hidrográficas dos mananciais de interesse regional do } \\
\text { Estado de São Paulo; }\end{array}$ \\
\hline $\begin{array}{l}\text { Decreto } 2.612 / 98 \\
\text { (alterado pelos } \\
\text { Decretos } 3.978 / 01 \\
\text { e 4.174/02) }\end{array}$ & Federal & Regulamenta o Conselho Nacional de Recursos Hidricos; \\
\hline Lei $9.984 / 00$ & Federal & $\begin{array}{l}\text { Dispõe sobre a criação da Agência Nacional de Águas (ANA), } \\
\text { entidade federal de implantação da Política Nacional de Recursos } \\
\text { Hídricos e de coordenação do Sistema Nacional de } \\
\text { Gerenciamento de Recursos Hídricos; }\end{array}$ \\
\hline Lei $9.966 / 00$ & Federal & $\begin{array}{l}\text { Dispõe sobre a prevenção, o controle e a fiscalização da poluição } \\
\text { causada por lançamento de óleo e outras substâncias nocivas ou } \\
\text { perigosas em águas sob jurisdição nacional: }\end{array}$ \\
\hline $\begin{array}{c}\text { Lei } n^{\circ} .9605 \\
\text { Seção } 3 \text { - artigo } 54\end{array}$ & Federal & $\begin{array}{l}\text { Dispõe que "causar poluição de qualquer natureza em niveis tais } \\
\text { que resultem ou possam resultar em danos à saúde humana, ou } \\
\text { que provoquem a mortandade de animais ou a destruição } \\
\text { significativa da flora"; }\end{array}$ \\
\hline $\begin{array}{c}\text { Resolução } \\
\text { CONAMA 357/05 }\end{array}$ & Federal & $\begin{array}{l}\text { Dispõe sobre a classificação dos corpos d'água e diretrizes } \\
\text { ambientais para o seu enquadramento, bem como estabelece as } \\
\text { condições e padrões de lançamento de efluentes, e dá outras } \\
\text { providências; }\end{array}$ \\
\hline
\end{tabular}


A norma NBR 10.004 não classifica os residuos de ETA como perigosos, em razão do lodo não ser caracterizado como tóxico. nem considera o elemento alumínio como uma substância que confere periculosidade aos resíduos (ABNT, 2002), apesar da presença deste elemento em grandes quantidades no lodo da ETA e do caráter acumulativo desses despejos em conseqüência do assoreamento provocado (PROSAB, 1999). A norma deixa a entender que o lodo da ETA pode ser considerado como um resíduo de classe II A - não inerte, por não se enquadrar na classificação de resíduos de classe I, já que não é considerado um residuo perigoso, e nem na classificação classe II B - inerte, por apresentar em alguns dos trabalhos já citados, alguns parâmetros superiores aos padrões de potabilidade de água.

No entanto, trabalhos publicados (PROSAB, 1999) comprovaram alterações físicoquímicas na água de corpos de água receptores de lodo de ETA, por causa da presença de aluminio. Embora a classificação classe II B - inerte limitasse seu descarte indiscriminado, somente trabalhos que avaliassem o depósito do lodo em corpos de água em longo prazo podem certificar a toxidade real desses resíduos, baseando-se em análises de águas superficiais, sedimentos e dos bentos, por um período mínimo de todo um ciclo hidrico.

Existe uma necessidade de consolidação das diferentes legislações, dispositivos, normas e resoluções específicas sobre os despejos resultantes de ETAs, com a implantação de programas que estabeleçam uma disposição adequada dos rejeitos da ETA, além do estabelecimento de parâmetros de qualidade das águas superficiais e do sedimento do fundo dos rios receptores. Um controle mais eficiente desses resíduos poderá ser definitivo uma vez que ocorra um aperfeiçoamento da gestão da água nas bacias hidrográficas, reunindo instrumentos econômicos previstos pelo princípio "poluidor-usuário-pagador", além de prioridades de investimento, políticas de captação e sistemas de licenciamento ambiental.

A cooperação entre as agências ambientais e de recursos hídricos tem ocorrido, mais especificamente, nos estados de São Paulo e Paraná. No estado de São Paulo, projetos recentes têm sido desenvolvidos entre a SABESP, a Poli/USP e o Centro de Química e Meio Ambiente do Instituto de Pesquisas Energéticas e Nucleares (CQMA-IPEN/CNEN), visando desenvolver pesquisa aplicada para a solução de problemas de saneamento. 
A partir dessa cooperação, o projeto aqui proposto originou-se com o objetivo de avaliar o estado da arte quanto aos sistemas de tratamento de água e o gerenciamento dos resíduos gerados. Uma outra meta seria a de compreender as características gerais desses resíduos como forma de possibilitar meios de estudo para a avaliação de seu impacto ambiental em uma bacia hidrográfica.

A bacia hidrográfica do rio Ribeira de Iguape, localizada em uma área denominada de preservação no estado de São Paulo (FIG.2), tem sofrido diversas ações negativas intensas, com comprometimento rápido da qualidade (CETEC, 2001). Sua escolha também se deu em função da bacia de drenagem apresentar grande disponibilidade de água, diante da pequena demanda quando comparada a outras, além por possuir um histórico alarmante quanto à contaminação de chumbo. Por outro lado, também é detentora do mais importante potencial mineral do estado de São Paulo, com grande variedade de substâncias minerais desde ferrosos, metálicos e preciosos, além de minerais raros como prata, antimônio e terras raras. Todo esse contexto se reflete nas características geoquimicas da água, do sedimento de drenagem, do material em suspensão e, conseqüentemente, na qualidade dos lodos gerados nas ETAs. Quando se avalia a evolução histórica do índice de qualidade da água na região, observa-se que nos últimos anos houve um aumento significativo do número de não conformidades dos padrões ambientais de qualidade da água, passando de excelente a regular (CETEC, 2001).

A SABESP utiliza atualmente a ETA de Registro (FIG.3), capital do Vale do Ribeira, como base de um sistema automatizado, desenvolvido pela própria empresa. $\mathrm{O}$ sistema pode monitorar remotamente e ajustar à distância todas as fáses dos processos de produção de água das estações de tratamento de água, alcançando-se satisfatoriamente todos os parâmetros estabelecidos e proporcionando diversas vantagens operacionais.

Deste modo, a facilidade de acesso aos dados disponíveis, além do fato do volume de descarga de despejos de resíduos sólidos serem representativos quando comparado com as outras ETAs da região, levou à decisão de se iniciar o estudo de avaliação do impacto de descarga de resíduos na Bacia Hidrográfica do Rio Ribeira de Iguape pela ETA da cidade de Registro. 


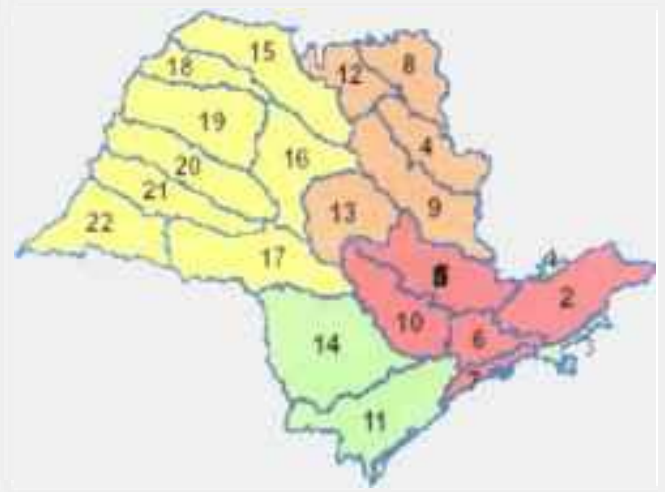
CLSSTFACATC
EASUMARIS
$\square$ a

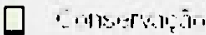

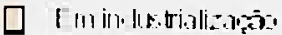

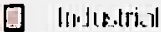

FIGURA 2 - Classificação das 22 unidades de gerenciamento de recursos hídricos (UGRHI) do estado de São Paulo (CETESB, 2004).

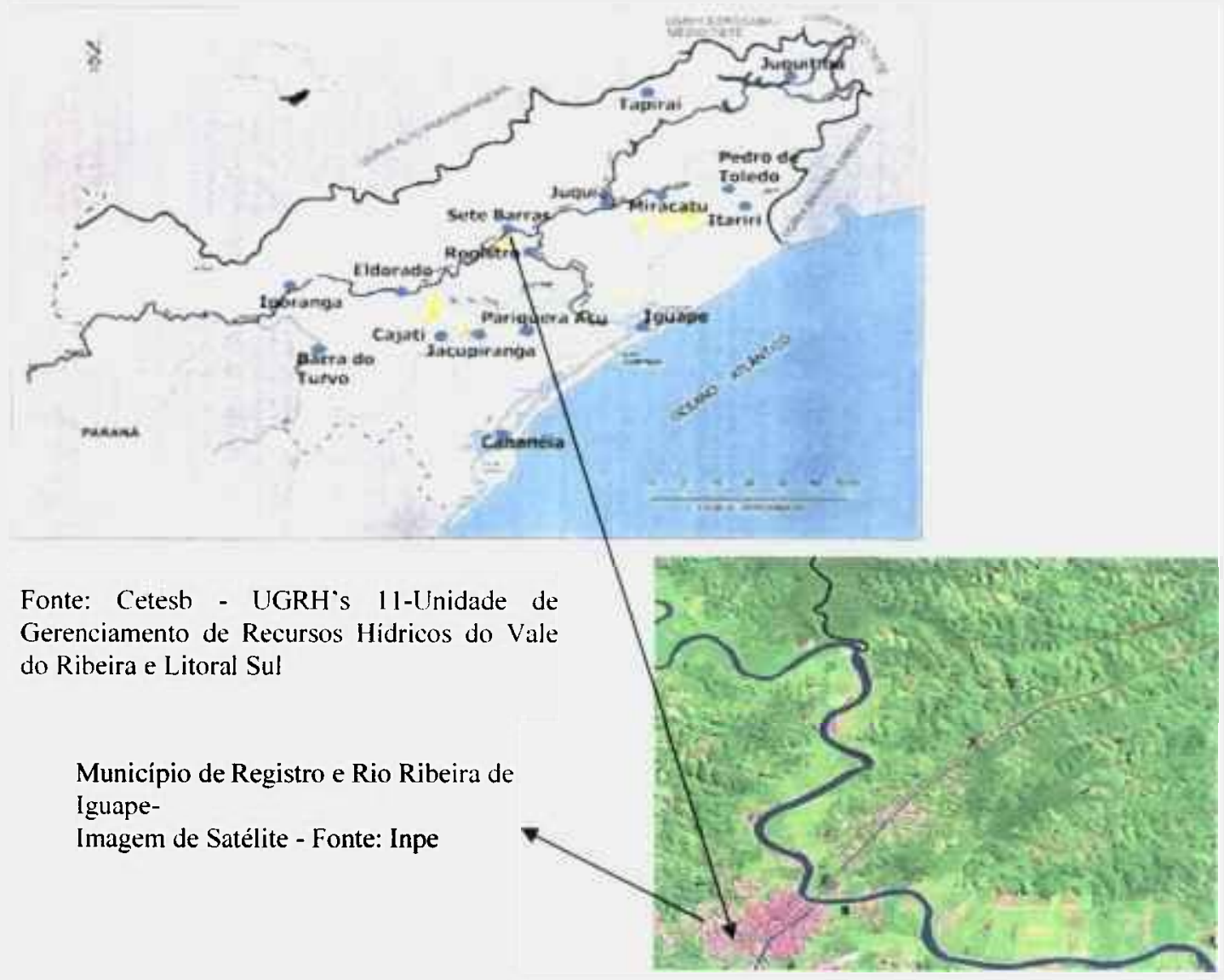

FIGURA 3. Localização da cidade de Registro.

O desenvolvimento deste estudo, conforme mencionado na introdução, faz parte de um subprojeto de pesquisa com financiamento FAPESP Políticas Públicas sobre o gerenciamento de lodos de ETAs. 


\subsection{Estação de tratamento de água}

O uso benéfico da água pela população requer uma série de parâmetros de qualidade de natureza estética e sanitária, de maneira a se atender as mais diferentes finalidades para o uso humano. A melhoria das condições de vida, relacionada especialmente à evolução nas condições de habitação e infra-estrutura, reflete que os sistemas de abastecimento de água e de coleta e tratamento de esgotos sanitários são serviços essenciais (Pires, 2001). A água utilizada para abastecimento é originária de dois tipos de mananciais, o manancial subterrâneo e o superficial, do qual a ETA é parte fundamental (Parsekian, 1998).

O sistema de tratamento de água tradicional ou completo de uma ETA é utilizado pela maioria dos sistemas produtores de água potável, notadamente no Estado de São Paulo (FIG.4). Esse sistema realiza a remoção de particulas finas em suspensão e em solução, presentes na água bruta. Para que o processo seja bem sucedido é necessária a utilização de produtos químicos, como sais de ferro e de alumínio, que são aplicados em unidades de coagulação para que possam desestabilizar a carga superficial dos sólidos em suspensão (partículas coloidais) na água bruta, formando flocos com dimensões o suficiente para sua posterior remoção.

Nas unidades de floculação, uma homogeneização adequada garante um maior contato entre os sólidos, formando flocos de grandes dimensões. Em seguida, a água é deixada em repouso em unidades de decantação, onde os flocos se depositam pela ação da gravidade formando o lodo. Esse material sedimentado fica retido em tanques decantadores durante vários dias (30-60 dias) e posteriormente é enviado para unidades de filtração, onde se removem da água os flocos formados e partículas menores, por meio de camadas de areia, carvão e antracito e por filtros com lavagem por água da própria ETA. A água separada passa por um processo de desinfecção e fluoretação e é enviada diretamente para o consumo (AWWA, 1974). 


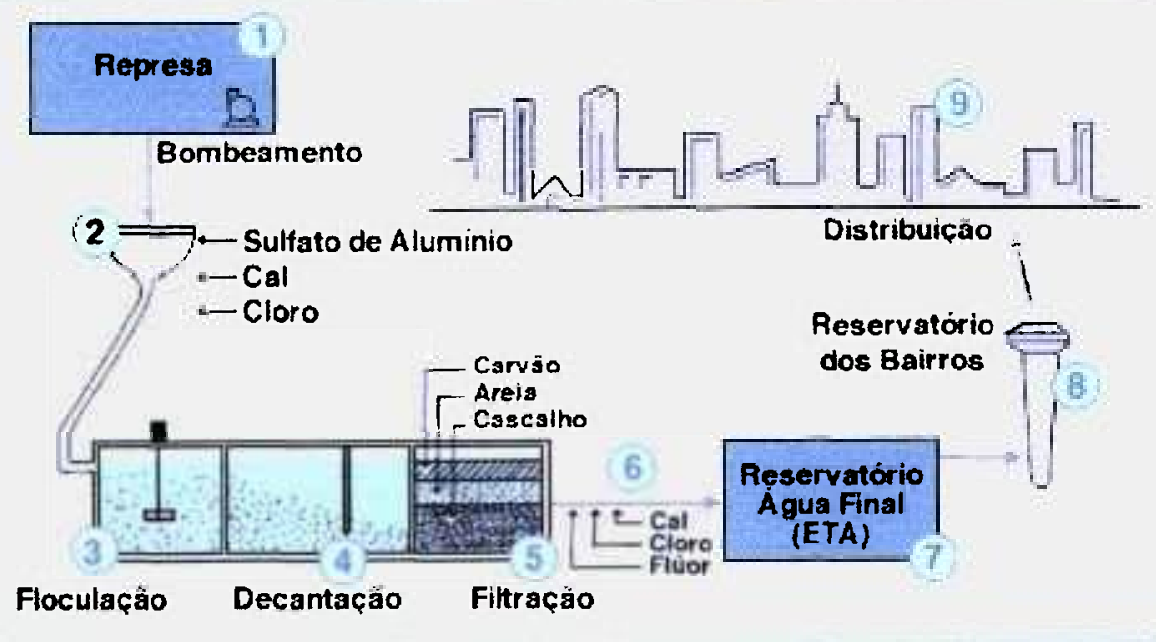

FIGURA 4 - Esquema de sistema de estação de tratamento de água (SABESP, 2003).

\subsection{Características do lodo de ETA}

Os resíduos sólidos (lodo) provenientes dos decantadores e da lavagem de filtros de uma ETA são compostos por impurezas contidas na água bruta e por substâncias químicas adicionadas durante o processo de tratamento da água, como substâncias coagulantes (normalmente sulfato de alumínio ou cloreto férrico), floculantes (sílica e polieletrólitos), controladores de sabor e odor (carvão ativado), algicidas (sulfato de cobre), corretores de alcalinidade (carbonato de sódio ou cálcio e hidróxidos de magnésio, sódio ou cálcio), desinfetantes (cloro gasoso, hipoclorito de sódio ou cálcio, bromo, iodo, peróxido de hidrogênio ou permanganato de potássio) e fluoretantes (fluorssilicato de sódio ou ácido fluorssilícico). O lodo produzido em diferentes ETAs pode, portanto, apresentar uma distinção na composição química dependendo das características da água bruta a ser tratada, tanto qualitativamente e/ou quantitativamente, conforme a necessidade dos produtos químicos a serem adicionados (Dharmappa, 1997).

Também devem ser consideradas as condições climatológicas em estações do ano diferentes, quando se consideram estudos dos resíduos para uma mesma ETA. Deste modo, uma avaliação do impacto produzido pelo lodo de uma ETA específica deve ser baseada na obtenção de parâmetros por meio da análise das características e períodos em que o lodo é produzido. 
O conhecimento das características físico-químicas dos lodos é fundamental na escolha de métodos de condicionamento e desidratação desses próprios resíduos. Isto pode ser observado no caso específico da ETA de Registro, localizada em uma região de alto índice pluviométrico e na qual se emprega especificamente apenas o sulfato de aluminio líquido como coagulante de partículas em suspensão e carbonato de sódio (barrilha) como corretor de acidez, influenciando de maneira marcante o resíduo final. O sulfato de alumínio adicionado reage com a alcalinidade natural das águas (quando existente), conforme a equação (1), a seguir:

$$
\mathrm{Al}_{2}\left(\mathrm{SO}_{4}\right)_{3} \cdot 18 \mathrm{H}_{2} \mathrm{O}+3 \mathrm{Ca}\left(\mathrm{HCO}_{3}\right)_{2}-->3 \mathrm{CaSO}_{4}+2 \mathrm{Al}(\mathrm{OH})_{3}+6 \mathrm{CO}_{2}+18 \mathrm{H}_{2} \mathrm{O}
$$

Como também se usa barrilha como corretor de acidez, observa-se a equação 2 , a seguir:

$$
\mathrm{Al}_{2}\left(\mathrm{SO}_{4}\right)_{3} .18 \mathrm{H}_{2} \mathrm{O}+3 \mathrm{Na}_{2} \mathrm{CO}_{3}+3 \mathrm{H}_{2} \mathrm{O}-->3 \mathrm{Na}_{2} \mathrm{SO}_{4}+2 \mathrm{Al}(\mathrm{OH})_{3}+3 \mathrm{CO}_{2}+18 \mathrm{H}_{2} \mathrm{O}
$$

O lodo de ETA é considerado um fluido não-newtoniano, insolúvel, de forte consistência gelatinosa (em função da elevada presença de hidróxidos) e oxidável. Como a água bruta utilizada para tratamento e posterior abastecimento não costuma ser poluída, o lodo resultante apresenta em grande parte uma composição inorgânica, possuindo uma pequena biodegradabilidade, com uma relação reduzida entre a Demanda Bioquímica de Oxigênio (DBO) e a Demanda Química de Oxigênio (DQO), onde DBO/DQO $<0,2$. Segundo Schmitt e Hall (1975), em uma análise de uma amostra de lodo podem ser encontrados até 72 elementos.

\section{4 Índice de qualidade da água}

A principal vantagem da utilização de um índice de avaliação da qualidade da água de um recurso hídrico é a facilidade de se interpretar em um único número, um parâmetro de definição que demonstre o teor de sua contaminação, apesar de não mostrar uma avaliação detalhada das variáveis individuais consideradas. A CETESB utiliza índices específicos para os principais usos do recurso hídrico desde o ano de 2002. 
O Índice de Abastecimento Público (IAP) é utilizado para águas destinadas para fins de abastecimento público, enquanto o Índice da Vida Aquática (IVA), para águas destinadas para a proteção da vida aquática, e a Classificação da Praia, para águas destinadas para o banho. Os índices são utilizados para a informação básica de qualidade de água para o público em geral, bem como para o gerenciamento ambiental das 22 UGRHI Unidades de Gerenciamento dos Recursos Hídricos em que se divide o estado de São Paulo (CETESB, 2005).

O IVA tem o objetivo exclusivo de avaliar a qualidade das águas para fins de proteção da fauna e flora em geral, diferente de um índice para avaliação da água para o consumo humano e recreação de contato primário. Este indice fornece informações sobre a qualidade da água em termos toxicológicos e seu grau de trofia, considerando a presença e concentração de contaminantes químicos tóxicos, seu efeito sobre os organismos aquáticos (toxicidade) e dois dos parâmetros considerados essenciais para a biota ( $\mathrm{pH}$ e oxigênio dissolvido).

O cálculo do IVA é baseado no Índice de Parâmetros Mínimos para a Preservação da Vida Aquática (IPMCA), bem como o Índice do Estado Trófico (IET), segundo a expressão:

$$
I V A=(I P M C A \times 1,2)+I E T
$$

Na ausência do valor do IET, o mesmo deverá ser igual à unidade. Se em uma dada amostra não estiverem disponíveis os resultados do teste de toxicidade, mas existirem resultados de oxigênio dissolvido e $\mathrm{pH}$, o IVA poderá ser calculado quando não estiver prevista a realização do teste de toxicidade.

Calcula-se o IVA também se a concentração do oxigênio dissolvido for menor do que $3 \mathrm{mg} . \mathrm{L}^{-1}$, ou quando o teste de toxicidade for semestral. Nesses casos, a ausência de resultados do grupo de substâncias tóxicas do IPMCA não implica na inviabilidade do cálculo do IVA. 
A proteção das comunidades aquáticas está prevista para corpos d'água enquadrados nas Classes 1, 2 e 3, conforme a legislação estadual (Regulamento da Lei 997/76, aprovado pelo Decreto Estadual 8468/76) e federal (Resolução CONAMA). Deste modo, aplica-se o IVA para esses ambientes (com exceção dos corpos d'água enquadrados na classe 4), por meio de cinco classificações de qualidade (TAB.7).

TABELA 7 - Classificações de qualidade das águas - IVA.

\begin{tabular}{|c|c|}
\hline Qualidade Ótima & IVA $=2,2$ \\
\hline Qualidade Boa & IVA $=3,2$ \\
\hline Qualidade Regular & $3,4 \leq$ IVA $\leq 4,4$ \\
\hline Qualidade Ruim & $4,6 \leq$ IVA $\leq 6,8$ \\
\hline Qualidade Péssima & IVA $>7,6$ \\
\hline
\end{tabular}

\subsubsection{Cálculo do índice IPMCA}

Para o cálculo do índice IPMCA, consideram-se dois grupos de parâmetros:

1) grupo de substâncias tóxicas (cobre, zinco, chumbo, cromo, mercúrio, níquel, cádmio, surfactantes e fenóis). Foram incluídos os parâmetros que são atualmente avaliados pela Rede de Monitoramento de Qualidade das Águas Interiores do Estado de São Paulo, identificando o nível de contaminação por substâncias potencialmente danosas às comunidades aquáticas. Poderão ser incluídos novos parâmetros que sejam importantes para a avaliação da qualidade das águas, mesmo em nível regional;

2) grupo de parâmetros essenciais (oxigênio dissolvido, $\mathrm{pH}$ e toxicidade).

Para cada parâmetro incluído no IPMCA (TAB.8), são estabelecidos três diferentes níveis de qualidade, com ponderảções numéricas de 1 a 3, e que correspondem a padrões de qualidade de água adotados pela CETESB e estabelecidos pela Resolução CONAMA 20/86 e pela legislação americana (USEPA, 1991) e francesa (Code Permanent: Environnement et Nuisances, 1986), as quais estabelecem limites máximos permissíveis de substâncias químicas na água, com o propósito de evitar efeitos de toxicidade crônica e aguda à biota aquática. Esses níveis refletem as seguintes condições de qualidade de água: 
TABELA 8 - Parâmetros do IPMCA, conforme níveis de qualidade (CETESB, 2005).

\begin{tabular}{|c|c|c|c|c|}
\hline Grupos & Parâmetros & Níveis & Faixa de variação & Ponderação \\
\hline \multirow{3}{*}{$\begin{array}{l}\text { Parâmetros } \\
\text { Essenciais } \\
\text { (PE) }\end{array}$} & $\mathrm{OD}\left(\mathrm{mg} \cdot \mathrm{L}^{-1}\right)$ & $\begin{array}{l}\text { A } \\
\text { B } \\
\text { C }\end{array}$ & $\begin{array}{l}>5,0 \\
3,0 \text { a } 5,0 \\
<3,0\end{array}$ & $\begin{array}{l}1 \\
2 \\
3\end{array}$ \\
\hline & pH (Sorensen) & $\begin{array}{l}\text { A } \\
\text { B } \\
\text { C }\end{array}$ & $\begin{aligned} 6,0 \text { a } 9,0 \\
5,0 \text { a }<6,0 \text { e }>9,0 \text { a } 9,5 \\
<5,0 \text { e }>9,5\end{aligned}$ & $\begin{array}{l}1 \\
2 \\
3 \\
\end{array}$ \\
\hline & Toxicidade & $\begin{array}{l}\text { A } \\
\text { B } \\
\text { C }\end{array}$ & $\begin{array}{l}\text { Não Tóxico } \\
\text { Efeito Crônico } \\
\text { Efeito Agudo }\end{array}$ & $\begin{array}{l}1 \\
2 \\
3\end{array}$ \\
\hline \multirow{9}{*}{$\begin{array}{l}\text { Substâncias } \\
\text { Tóxicas } \\
\text { (ST) }\end{array}$} & Cádmio (mg.L $\left.{ }^{-1}\right)$ & $\begin{array}{l}\mathrm{A} \\
\mathrm{B} \\
\mathrm{C}\end{array}$ & $\begin{array}{c}>0,001 \\
>0,001 \text { a } 0,005 \\
>0,005\end{array}$ & $\begin{array}{l}1 \\
2 \\
3 \\
\end{array}$ \\
\hline & Cromo (mg. $\mathrm{L}^{-1}$ ) & $\begin{array}{l}\mathrm{A} \\
\mathrm{B} \\
\mathrm{C}\end{array}$ & $\begin{array}{c}>0,05 \\
>0,05 \text { a } 1,00 \\
>1,00\end{array}$ & $\begin{array}{l}1 \\
2 \\
3\end{array}$ \\
\hline & Cobre (mg. $\left.\mathrm{L}^{-1}\right)$ & $\begin{array}{l}\text { A } \\
\text { B } \\
\text { C }\end{array}$ & $\begin{array}{c}>0,02 \\
>0,02 \text { a } 0,05 \\
>0,05 \\
\end{array}$ & $\begin{array}{l}1 \\
2 \\
3 \\
\end{array}$ \\
\hline & Chumbo (mg. $\left.\mathrm{L}^{-1}\right)$ & $\begin{array}{l}\text { A } \\
\text { B } \\
\text { C } \\
\end{array}$ & $\begin{array}{c}>0,03 \\
>0,03 \text { a } 0,08 \\
>0,08\end{array}$ & $\begin{array}{l}1 \\
2 \\
3\end{array}$ \\
\hline & Mercúrio (mg. $\mathrm{L}^{-1}$ ) & $\begin{array}{l}\mathrm{A} \\
\mathrm{B} \\
\mathrm{C}\end{array}$ & $\begin{array}{c}>0,0002 \\
>0,0002 \text { a } 0,001 \\
>0,001\end{array}$ & $\begin{array}{l}1 \\
2 \\
3\end{array}$ \\
\hline & Niquel (mg.L $\mathrm{L}^{-1}$ ) & $\begin{array}{l}\mathrm{A} \\
\mathrm{B} \\
\mathrm{C}\end{array}$ & $\begin{array}{c}>0,025 \\
>0,025 \text { a } 0,160 \\
>0,160\end{array}$ & $\begin{array}{l}1 \\
2 \\
3 \\
\end{array}$ \\
\hline & Fenóis (mg. $\mathrm{L}^{-1}$ ) & $\begin{array}{l}\mathrm{A} \\
\mathrm{B} \\
\mathrm{C}\end{array}$ & $\begin{array}{c}>0,001 \\
>0,001 \text { a } 0,050 \\
>0,050\end{array}$ & $\begin{array}{l}1 \\
2 \\
3\end{array}$ \\
\hline & Surfactantes $\left(\mathrm{mg} \cdot \mathrm{L}^{-1}\right)$ & $\begin{array}{l}\mathrm{A} \\
\mathrm{B} \\
\mathrm{C} \\
\end{array}$ & $\begin{array}{c}>0,5 \\
>0,5 \text { a } 1,00 \\
>1,00 \\
\end{array}$ & $\begin{array}{l}1 \\
2 \\
3 \\
\end{array}$ \\
\hline & Zinco (mg. $\mathrm{L}^{-1}$ ) & $\begin{array}{l}\mathrm{A} \\
\mathrm{B} \\
\mathrm{C}\end{array}$ & $\begin{array}{c}>0,18 \\
>0,18 \text { a } 1,00 \\
>1,00\end{array}$ & $\begin{array}{l}1 \\
2 \\
3\end{array}$ \\
\hline
\end{tabular}

Nível A: Padrões de qualidade de água da Legislação Federal (CONAMA 20/86), para classes 1 e 2 (BRASIL, 1986).

Niveis B e C: Limites obtidos das legislações francesa e americana (CODE PERMANENT:

ENVIRONNEMENT ET NUISANCES, 1986), (USEPA, 1991). 
Nível A: Águas com características desejáveis para manter a sobrevivência e a reprodução dos organismos aquáticos. Atende aos padrões de qualidade da Resolução CONAMA 20/86 (ponderação 1).

Nível B: Águas com características desejáveis para a sobrevivência dos organismos aquáticos, porém a reprodução pode ser afetada em longo prazo (ponderação 2).

Nível C: Águas com caracteristicas que podem comprometer a sobrevivência dos organismos aquáticos (ponderação 3).

Dadas às ponderações para os parâmetros determinados em uma amostra de água, o IPMCA é calculado da seguinte forma:

$$
\mathrm{IPMCA}=\mathrm{PE} \times \mathrm{ST}
$$

Onde:

PE: Valor da maior ponderação do grupo de parâmetros essenciais;

ST: Valor médio das três maiores ponderações do grupo de substâncias tóxicas. Este valor é um número inteiro e o critério de arredondamento deverá ser o seguinte: valores menores que 0,5 serão arredondados para baixo e valores maiores ou iguais a 0,5 serão arredondados para cima.

O valor do IPMCA pode variar de 1 a 9 , sendo subdividido em quatro faixas de qualidade, classificando as águas para proteção da vida aquática, conforme a TAB.9, a seguir:

TABELA 9 - Classificação do valor do IPMCA para avaliação da qualidade da água.

\begin{tabular}{|c|c|}
\hline IPMCA & Qualidade da água \\
\hline 1 & Boa \\
2 & Regular \\
3 e 4 & Ruim \\
$\geq 6$ & Péssima \\
\hline
\end{tabular}




\subsubsection{Cálculo do IET}

O Índice do Estado Trófico tem por finalidade classificar corpos d'água em diferentes graus de trofia, ou seja, avaliar a qualidade da água quanto ao enriquecimento por nutrientes e seu efeito relacionado ao crescimento excessivo das algas. O Índice do Estado Trófico adotado pela CETESB foi introduzido por Carlson modificado por Toledo et al. (1983) e Toledo (1990) que, através de método estatístico baseado em regressão linear, alterou as expressões originais para adequá-las a ambientes subtropicais. Este índice utiliza três avaliações de estado trófico em função dos valores obtidos para as variáveis: transparência, clorofila e fósforo total (CETESB, 2005).

Das três variáveis citadas para o cálculo Índice do Estado Trófico, foi aplicado neste trabalho apenas o fósforo total, uma vez que os valores de transparência muitas vezes não são representativos do estado de trofia, que pode ser afetada pela turbidez decorrente de material mineral em suspensão e não apenas pela densidade de organismos planctônicos, e também porque não se realizaram avaliações correspondentes à clorofila durante este estudo. Conforme CETESB (2005), como neste caso não há resultados para a clorofila, o índice será calculado com o parâmetro disponível e considerado equivalente ao IET, devendo, apenas, constar uma observação junto ao resultado, informando que apenas um dos parâmetros foi utilizado.

Os resultados correspondentes ao fósforo, IET(P), devem ser entendidos como uma medida do potencial de eutrofização, já que este nutriente atua como o agente causador do processo. Portanto, o Índice do Estado Trófico apresentado e utilizado no cálculo do IVA, será composto pelo Índice do Estado Trófico para o fósforo - IET(P), conforme equação (5):

$$
\operatorname{IET}(\mathrm{P})=10\{6-[\ln (80,32 / \mathrm{P}) / \ln 2]\}
$$

Onde: $\ln =$ logaritmo natural

$\mathrm{P}=$ concentração de fósforo total medida à superficie da água, em $\mu \mathrm{g} \cdot \mathrm{L}^{-1}$ 
Em virtude da variabilidade sazonal dos processos ambientais, que têm influência sobre o grau de eutrofização de um corpo hídrico, esse processo pode apresentar variações no decorrer do ano, havendo épocas em que se desenvolve de forma mais intensa e outros em que pode ser mais limitado. Em geral, no início da primavera, com o aumento da temperatura da água, maior disponibilidade de nutrientes e condições propícias de penetração de luz na água, é comum observar-se um incremento do processo, após o período de inverno, em que ele se mostrava menos intenso (Salomons, 1995).

Nesse sentido, a determinação do grau de eutrofização médio anual de um corpo hídrico pode não identificar de forma explícita as variações que ocorreram ao longo do periodo anual. Para a classificação deste índice foram adotados os seguintes estados de trofia: oligotrófico, mesotrófico, eutrófico e hipereutrófico, cujos limites e características estão descritos na TAB.10.

TABELA 10 - Classificação do Índice do Estado Trófico (IET), segundo Índice de Carlson modificado (CETESB, 2005).

\begin{tabular}{ccccc}
\hline Estado trófico & Critério & $\begin{array}{c}\text { Transparência } \\
(\mathrm{m})^{*}\end{array}$ & $\begin{array}{c}\text { Fósforo total }-\mathrm{P} \\
\left(\mathrm{mg} \cdot \mathrm{m}^{-3}\right)\end{array}$ & $\begin{array}{c}\text { Clorofila } \\
\left(\mathrm{mg} \cdot \mathrm{m}^{-3}\right)\end{array}$ \\
Oligotrófico & IET $=44$ & $\mathrm{~S}=1,6$ & $\mathrm{P}=26,5$ & $\mathrm{CL}=33,8$ \\
Mesotrófico & $44<\mathrm{IET}=54$ & $1,6>\mathrm{S}=0,8$ & $26,5<\mathrm{P}=53,0$ & $3,8<\mathrm{C}=10,3$ \\
Eutrófico & $54<\mathrm{IET}=74$ & $0,8>\mathrm{S}=0,2$ & $53,0<\mathrm{P}=211,9$ & $10,3<\mathrm{CL}=76,1$ \\
Hipereutrófico & IET $>74$ & $0,2>\mathrm{S}$ & $211,90<\mathrm{P}$ & $76,1<\mathrm{CL}$ \\
\hline
\end{tabular}

* Disco de Seochi

\subsection{Avaliação do impacto ambiental}

O despejo de substâncias químicas decorrentes de atividades humanas e disponibilizadas de forma antropogênica para o meio ambiente pode conter níveis de concentrações de metais com efeitos potencialmente nocivos nas espécies vivas presentes no ecossistema. Neste caso, é imprescindivel a avaliação do grau de exposição do corpo receptor à fonte poluidora por meio de um monitoramento de parâmetros ambientais que apresentem informações não apenas dos fluxos dos poluentes através do ambiente, mas também da compreensão dos processos de degradação do próprio ecossistema. 
Os tipos de amostras a serem coletadas durante o periodo de um monitoramento podem depender dos prováveis caminhos do poluente em potencial no ambiente de estudo. Para a avaliação do impacto do lodo no ambiente de entorno da ETA, além de ser necessária a caracterização do próprio material a ser descartado, o recolhimento de amostras de águas superficiais e sedimentos dos corpos d'água receptores consideram possíveis mudanças físico-químicas nestes compartimentos pelo contato direto com o efluente. Segundo Combest (1991), metais em nível de traços, por exemplo, depois de serem lançados em ambientes aquáticos podem encontrar-se distribuídos na água, no sedimento e na biota.

Na TAB.11 são mostrados os indicadores químicos utilizados, em especial os metais tóxicos, considerados contaminantes químicos importantes para a avaliação e gerenciamento de resíduos perigosos. Os efeitos tóxicos desses metais podem ser encontrados em diversos trabalhos descritos na literatura, principalmente por seus efeitos bioacumulativos, podendo causar uma série de agravos à saúde (Lemes, 2001; Muñoz, 2002). 


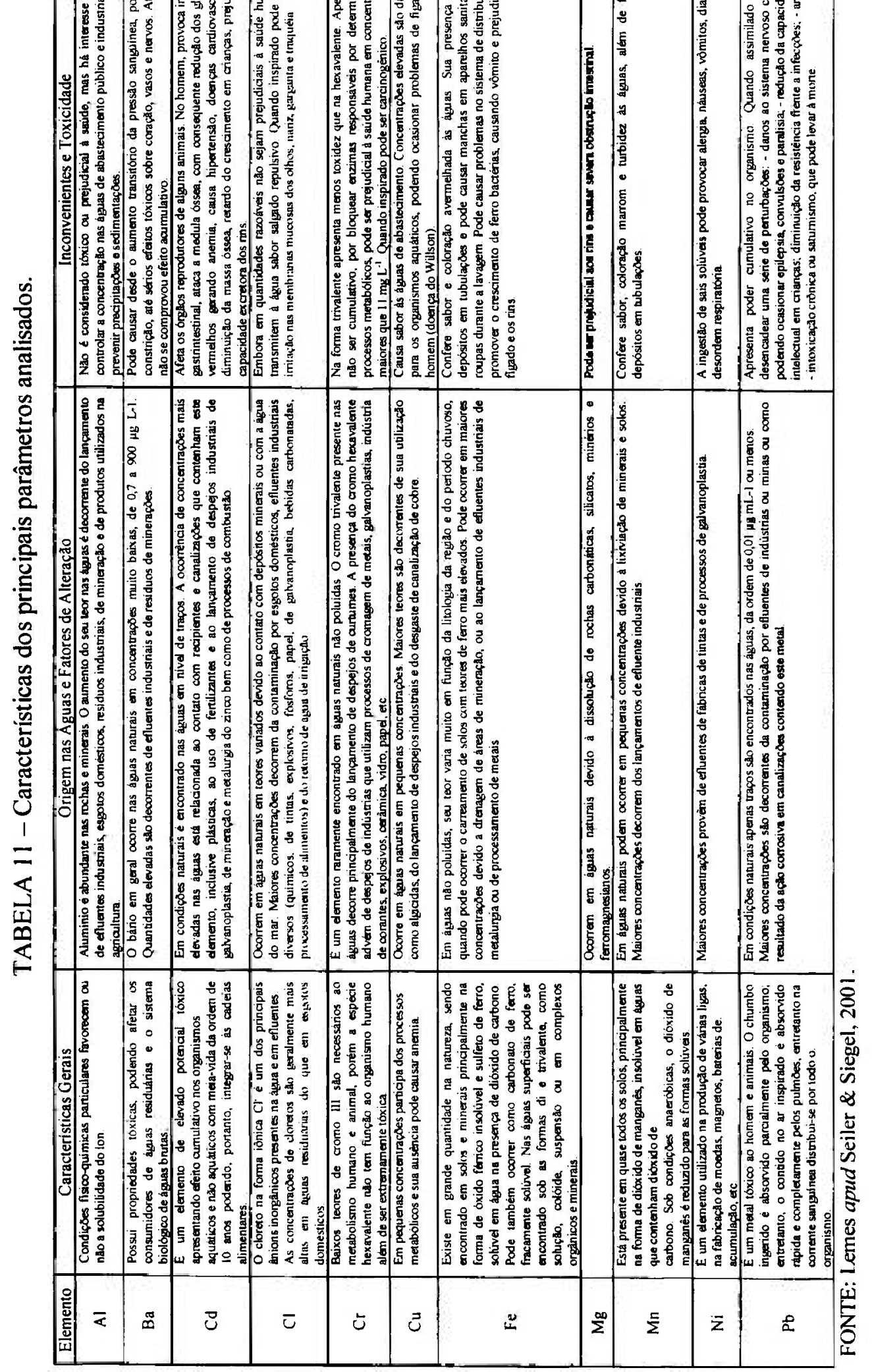




\subsubsection{Avaliação das amostras de águas superficiais e sedimentos}

A avaliação das águas superficiais possibilita quantificar o nível de impacto de um despejo pela presença de contaminantes solúveis no meio aquático, enquanto a avaliação de sedimentos de fundo permite verificar a qualidade do sistema aquático em razão da presença de contaminantes que se mantêm insolúveis ou parcialmente solúveis em águas superficiais. Nos dois casos, a avaliação é realizada comparando-se coletas realizadas a montante e a jusante dos despejos, em conseqüência de alterações físico-químicas no próprio meio aquático, como mudanças de $\mathrm{pH}$, do potencial redox ou da presença de complexantes orgânicos. As análises dos bentos nos pontos de coleta, avaliando-se as influências de poluentes do lodo incorporados nos organismos aquáticos, também são importantes, uma vez que os sedimentos podem ser remobilizados por alterações do meio circundante (Rocha, 1999).

O sedimento pode ser definido como o material que se encontra depositado ao fundo de um curso d'água, dividindo-se em partículas de solo, água intersticial e matéria orgânica, que ocupa até $10 \%$ da fase sólida do sedimento. Os sedimentos são importantes para o ecossistema aquático, porém podem causar problemas em situações de excessiva sedimentação por atividade humana ou por acúmulo de contaminantes. $O$ controle de contaminantes em sedimentos não tem uma resposta tão rápida quanto um controle realizado no ar e na água, em virtude do curto tempo de permanência nestes meios.

Sedimentos e solos possuem uma capacidade de armazenarem contaminantes que depende diretamente da sua composição, necessitando de um tempo de eliminação maior por processos de dissolução e diluição. No ciclo hidrológico, menos de $1 \%$ dos contaminantes são dissolvidos em água e considerados mais disponíveis para organismos (biodisponiveis). Em se tratando de contaminantes inorgânicos, como metais tóxicos, a capacidade de adsorção está relacionada à área superficial de contato e propriedades das partículas, como ocorre em minerais argilosos. Da mesma forma que a argila e material húmico, minerais como quartzo e feldspato adsorvem metais por meio de processos de troca iônica, tornando-os relativamente disponíveis em razão do equilibrio entre os metais adsorvidos e dissolvidos no meio aquático. 
Este processo de adsorção inibe a lixiviação natural de contaminantes, reduzindo sua biodisponibilidade. De outro modo, estão os metais ligados à estrutura cristalina de alguns minerais, deixando-os permanentemente indisponiveis. Entre estas duas situações estão os metais potencialmente disponíveis, incluindo-se os carbonatos, sulfetos, óxidos e hidróxidos, além de metais adsorvidos, ocluidos ou quelados com óxidos de ferro e material húmico.

A mobilidade dos contaminantes, neste caso, está intimamente relacionada a parâmetros que controlam diretamente a sua retenção ou disponibilidade por lixiviação, como $\mathrm{pH}$ (decorrente da presença de carbonatos com tampões naturais), condição redox e a presença de agentes complexantes. Condições no meio aquático que sejam fortemente ácidas podem diminuir a atividade microbiana e aumentar os niveis de solubilidade dos metais tóxicos, enquanto condições fracamente ácidas, neutras e levemente alcalinas têm efeito contrário. Alterações no potencial redox podem resultar em um aumento ou diminuição da retenção ou liberação dos metais (EPA, 1991). Portanto, mudanças nestes parâmetros causadas por atividades humanas podem perturbar o equilibrio naturalmente existente por meio de uma maior disponibilização dos metais, causando um aumento do impacto destes contaminantes no meio aquático (TAB.12).

TABELA 12 - Influência de mudanças químicas em metais potencialmente disponíveis (Salomons, 1995).

\begin{tabular}{|c|c|c|c|}
\hline TIPO DO METAL & CONDIÇÃO INICIAL & $\begin{array}{c}\text { MUDANÇA } \\
\text { AMBIENTAL }\end{array}$ & RESULTADOS \\
\hline $\begin{array}{c}\text { Carbonatos, óxidos e } \\
\text { hidróxidos }\end{array}$ & Sais no sedimento & Reduções de pH & $\begin{array}{c}\text { Liberação dos metais na } \\
\text { forma de sais solúveis. }\end{array}$ \\
\hline $\begin{array}{c}\text { Adsorvidos em óxidos } \\
\text { de ferro }\end{array}$ & $\begin{array}{c}\text { Adsorvidos no } \\
\text { sedimento }\end{array}$ & $\begin{array}{c}\text { Sedimento se torna } \\
\text { redutor }\end{array}$ & $\begin{array}{c}\text { Oxidos de ferro tornam- } \\
\text { se instáveis, liberando } \\
\text { metais. }\end{array}$ \\
\hline $\begin{array}{c}\text { Quelados em Material } \\
\text { Húmico }\end{array}$ & Quelados no sedimento & $\begin{array}{c}\text { Imobiliza fortemente os metais presentes em } \\
\text { sedimentos oxidados e reduzidos. }\end{array}$ \\
\hline Sulfetos & Precipitado insolúvel & $\begin{array}{c}\text { Sedimento se torna } \\
\text { oxidado }\end{array}$ & $\begin{array}{c}\text { Sulfetos se tornam } \\
\text { instáveis, oxidando-se a } \\
\text { sulfatos e liberando os } \\
\text { metais. }\end{array}$ \\
\hline
\end{tabular}


A importância neste projeto de se analisar amostras de sedimento nos cursos d'água no entorno da ETA é a de se avaliar a mobilidade dos metais e a capacidade dos sedimentos de reterem contaminantes do lodo descartado (Salomons, 1995; Alloway \& Ayres, 1994), identificando-o como uma provável fonte de contaminação. Deste modo, procurou-se caracterizar os sedimentos possivelmente contaminados com a identificação dos contaminantes presentes.

A qualidade dos sedimentos coletados nos cursos d'água no entorno da ETA de Registro foi avaliada de acordo com os valores limites estabelecidos pelo protocolo canadense para a proteção de vida aquática, por meio do Conselho Canadense de Ministros para o Meio Ambiente (CCME, 1999). Estes parâmetros são também utilizados para a avaliação de sedimentos pela CETESB (CETESB, 2004), os quais estabelecem dois níveis de classificação: TEL ("Threshold Effect Level"), que representa a concentração abaixo da qual não são esperados efeitos adversos sobre organismos aquáticos e PEL ("Probable Effect Level"), que descreve concentrações acima das quais são esperados efeitos adversos severos sobre organismos aquáticos. Para a maior parte dos metais analisados, é esperado um background de concentração que seja normal e característico de toda a área de amostragem, decorrente do solo e das rochas da região, excluindo-se contribuições de fontes antropogênicas. 


\section{4 Área de Estudo}

\subsection{A bacia do rio Ribeira de Iguape}

A Bacia Hidrográfica do rio Ribeira de Iguape situa-se aproximadamente entre as latitudes $23^{\circ} 30^{\prime} \mathrm{e} 25^{\circ} 30^{\prime}$ Sul e longitude $46^{\circ} 50^{\prime} \mathrm{e} 50^{\circ} 00^{\prime}$ Oeste, abrangendo uma área de $24.980 \mathrm{~km}^{2}$, dos quais $61 \%$ pertencem ao estado de São Paulo e $39 \%$ ao estado do Paraná. Apresenta-se quase paralelamente à orla marítima, com uma orientação SO-NE, confrotando-se ao norte e a leste com a bacia do rio Paranapanema e ao sul com a bacia do rio Iguaçu e formando um grande leque, cujas nervuras estão encaixadas em zona montanhosa e cujo relevo desce em direção às nervuras centrais representadas pelo rio Ribeira de Iguape e seu principal afluente, o rio Juquiá.

O rio Ribeira de Iguape nasce no estado do Paraná, formado pelos rios Açungui e Ribeirão Grande, a uma altitude de $1.000 \mathrm{~m}$, permanecendo com o nome de rio Ribeira até a cidade de Eldorado, no estado de São Paulo. Apresenta uma extensão de aproximadamente $470 \mathrm{~km}$, com $120 \mathrm{~km}$ em terras paranaenses e sua foz localizada no município de Iguape (Hogan, 2002). A partir da jusante da confluência dos rios Ribeira de Iguape e Juquiá, aproximadamente na região central do Vale do Ribeira, observa-se que a topografia da região vai suavizando, transformando-se em uma ampla planície que se estende até a orla litorânea. Abrange 32 municípios, sendo nove no estado do Paraná e 23 no estado de São Paulo. Em geral, são cidades de porte pequeno com destaque para Registro, Iguape, Apiaí, Juquitiba e Juquiá, na parte paulista e Rio Branco do Sul na parte paranaense (FIG.5). Juntamente com o Complexo Estuário Lagunar de Iguape, Cananẻia e Paranaguá, compõem o denominado Vale do Ribeira, com uma extensão de 260 km e 140 km de costa para o Oceano Atlântico e uma população estimada em 400 mil habitantes (Hogan, 2002).

$\mathrm{O}$ alto e o médio Vale do Ribeira localizam-se na zona serrana, apresentando um relevo muito complexo, com até $1.300 \mathrm{~m}$ sobre o mar e com amplitudes locais de até $300 \mathrm{~m}$. Tais áreas correspondem às porções de cabeceira e médio curso dos rios Ribeira de Iguape e Juquiá, situadas nos planaltos paranaense e paulistano, devido ao recuo da Serra do Mar. 
Os mais elevados divisores de águas são suportados principalmente por gnaisses, granitos e, em menor parte, por rochas quartzíticas. Zonas mais baixas, onde se localizam os municípios de Apiaí, Iporanga e Ribeira, são baseadas em filitos e xistos com calcários intercalados.

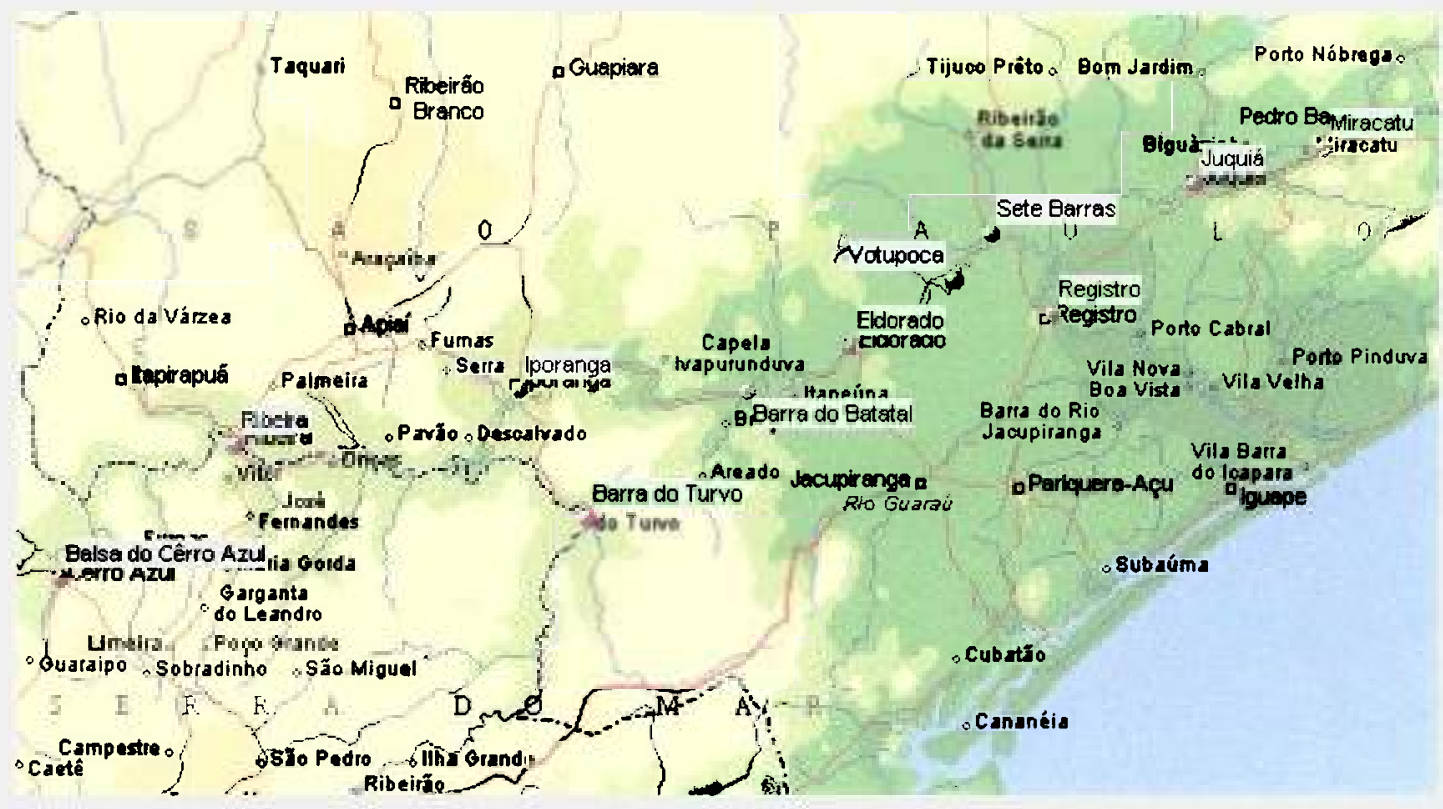

FIGURA 5 - Localização da bacia hidrográfica do Ribeira de Iguape (SABESP, 2001).

A Bacia Hidrográfica do rio Ribeira de Iguape desenvolve-se sobre rochas arqueanas e proterozóicas, formando uma seqüência complexa em função de inúmeros eventos termodinâmicos que ocorreram na região. Sua origem deve-se a uma particularidade da geologia do estado de São Paulo que corresponde a toda a faixa costeira situada entre o Vale do Ribeira e os confins do estado do Rio de Janeiro. Toda esta região é constituída de gnaisses e granitos, rochas muito resistentes à erosão e capazes de manter em destaque a Serra do Mar, que é um extenso conjunto de escarpas e montanhas que muito se aproximam da orla marinha. Contudo, na área do Vale do Ribeira chegam ao mar os xistos e filitos, rochas que por serem menos resistentes à erosão, permitiram que a drenagem tributária direta do Atlântico recuasse profundamente para o interior do continente, expandindo-se amplamente através da abertura dos vales dos rios Juquiá, São Lourenço, Jacupiranga, além do próprio rio Ribeira, que recuou suas nascentes para o interior do estado do Paraná. Desta forma, o frontão escarpado da Serra do Mar regrediu da borda até $60 \mathrm{~km}$ para se apoiar nos batólitos granolíticos da serra de Paranapiacaba. Todo esse processo erosivo vem se realizando durante os 70 milhões de anos do período Cenozóico. 
No Quaternário, derradeiro milhão de anos deste período, o nível do mar sofreu em todo o mundo grandes oscilações devido às sucessivas fases de congelamento e degelo do período glacial. O crescimento das massas de gelo nas regiões frias provocou o abaixamento do nível do mar a $100 \mathrm{~m}$ em relação ao nivel do mar atual, ativando a erosão fluvial. Posteriormente, o mar novamente em ascensão inundou as depressões formando as planícies costeiras e as baías, ainda não de todos assoreadas. Estas áreas de relevo suave correspondem hoje às planicies aluviais desenvolvidas ao longo dos rios Ribeira, Juquiá e Jacupiranga (Hogan, 2002), que compõem a porção sul da bacia, destacando-se o relevo cáustico associado à presença de rochas calcárias e com formações de idade arqueana, constituída de migmatitos e gnaisses e também xistos, quartzitos, rochas calcossilicatadas, metabasitos e granulitos. Na porção central da bacia, do proterozóico inferior, encontramse micaxistos, ardósias, filitos, mármores, metabasitos, quartzitos, rochas calcossilicatadas, gnaisses, anfibolitos e migmatitos.

Na porção oeste podem ser encontrados orto e paragnaisses, além de micaxistos, anfibolitos, talcoxistos e metaultrabasitos. A porção norte é do período pré-cambriano, constituido especialmente por migmatitos, gnaisses, xistos, filitos, quartzitos, anfibolitos, mármore e dolomitos. No terço médio e inferior do rio Ribeira de Iguape observam-se extensos depósitos sedimentares pertencentes a aluviões fluviais e marinhos. A erosão hídrica é comum em toda a bacia, em razão da natureza e espessura dos solos, às amplitudes do relevo e à alta pluviosidade.

A região possui um patrimônio ambiental que se traduz em mais de 2,1 milhões de hectares de florestas (aproximadamente $21 \%$ da área remanescente de Mata Atlântica do Brasil), contendo o maior número de unidades de conservação da mata atlântica e a maior extensão contínua de áreas remanescentes de mata atlântica do estado de São Paulo (mais de meio milhão de hectares), além de um dos mais importantes patrimônios espeleológicos do país, protegidos pela criação de sete parques estaduais, duas estações ecológicas e três áreas de preservação (TAB.13). 
TABELA 13. Unidades de conservação do Vale do Ribeira e litoral sul do estado de São Paulo: municípios abrangidos, instrumento legal de criação e área em ha.

\begin{tabular}{|c|c|c|c|}
\hline $\begin{array}{l}\text { UNIDADES DE } \\
\text { CONSERVAÇĀO }\end{array}$ & MUNICIPIOS A BRANGIDOS (2) & $\begin{array}{l}\text { INSTRUMENTO } \\
\text { LEGAL DE } \\
\text { CRIAÇÃO (3) } \\
\end{array}$ & $\begin{array}{c}\text { ÁREA } \\
\text { (em ha.) }\end{array}$ \\
\hline \multicolumn{4}{|c|}{ Parques Estaduais } \\
\hline 1. Carlos Botelho & $\begin{array}{l}\text { [São Miguel Arcanjo], Tapiraí, Capão Bonito, Sete } \\
\text { Barras. }\end{array}$ & D. $19.499 / 82$ & $37.644,36$ \\
\hline 2. Ilha do Cardoso & [Cananéia] & D. $40.319 / 62$ & $13.600,00$ \\
\hline 3. Intervales & $\begin{array}{l}\text { [Ribeirão Grande], Eldorado, Iporanga, Sete } \\
\text { Barras. }\end{array}$ & D. $40.135 / 95$ & $46.086,00$ \\
\hline 4. Jacupiranga & $\begin{array}{c}\text { Barra do Turvo, Cananéia, Jacupiranga, [Eldorado], } \\
\text { Cajati, Iporanga. }\end{array}$ & D. $145 / 69$ & $150.000,00$ \\
\hline \multirow[t]{2}{*}{ 5. Pariquera Abaixo } & [Pariquera-Açu] & L. $8.873 / 94$ & $2.360,00$ \\
\hline & Serra do Mar & D. $10.251 / 77$ & \\
\hline 1. Núcleo Curucutu & Itanhaém, [Juquitiba], São Paulo & $19.448 / 82$ & $9.058,06$ \\
\hline 2. Núcleo Pilões/Cubatão & $\begin{array}{l}\text { [Cubatão], São Vicente, São Paulo, São Bernardo } \\
\text { do Campo, Santo André, Bertioga, Praia Grande, } \\
\text { Mongaguá, Itanhaém, Ribeirão Pires, Pedro de } \\
\text { Toledo, Rio Grande da Serra, Biritiba-Mirim, Mogi } \\
\text { das Cruzes. }\end{array}$ & D. $10.251 / 77$ & $85.026,48$ \\
\hline $\begin{array}{l}\text { 3. Núcleo Pedro de } \\
\text { Toledo }\end{array}$ & $\begin{array}{l}\text { [Pedro de Toledo], Juquitiba, Miracatu, São } \\
\text { Lourenço da Serra. }\end{array}$ & D. $10.251 / 77$ & $50.853,81$ \\
\hline 4. Turístico Alto Ribeira & [lporanga], Apiaí & D. $32.283 / 58$ & $35.884,28$ \\
\hline \multicolumn{4}{|c|}{ Estaçōes Ecológicas } \\
\hline 1. Chauás & lguape]. & D. $26.719 / 87$ & \\
\hline 2. Juréia-Itatins & Iguape, [Peruíbe], Itariri, Miracatu. & $\begin{array}{c}\text { D. } 24.646 / 86 ; \mathrm{L} \text {. } \\
5.649 / 87\end{array}$ & $79.270,00$ \\
\hline \multicolumn{4}{|c|}{ Áreas de Proteção Ambiental (APAs) } \\
\hline $\begin{array}{l}\text { 1. Cananéia - Iguape - } \\
\text { Peruibe }\end{array}$ & Iguape, Utha Comprida, Itariri, Miracatu e Peruíbe. & DF $90.347 / 84$ & $\cdots$ \\
\hline 2. Serra do Mar & $\begin{array}{l}\text { Barra do Turvo, Capão Bonito, Eldorado. Ibiúna, } \\
\text { Iporanga, Juquiá, Juquitiba, Miracatu, Pedro de } \\
\text { Toledo, Pilar do Sul, Sete Barras e Tapirai. }\end{array}$ & DE $22.717 / 84$ & $\cdots$ \\
\hline 3. Uha Comprida & tha Comprida & $\begin{array}{c}\text { DE } 26.881 / 87 \text { e DE } \\
30.817 / 89\end{array}$ & $\cdots$ \\
\hline
\end{tabular}

Fonte: Atlas das Unidades de Conservação Ambiental do Estado de São Paulo, Parte I - Litoral, SMA, 1996. (1) Situação em 31/12; (2) O Município onde se encontra a sede da Unidade de Conservação está destacado entre colchetes; (3) D.- Decreto; L.- Lei; D.L.- Decreto Lei; DE. - Decreto Estadual e D..F.Decreto Federal. As APAs ocupam parcial ou totalmente os municipios citados. Apud SEADE, (htpp://www.seade.gov.br).

O Vale do Ribeira passou a integrar a Reserva da Biosfera da Mata Atlântica a partir de 1992 e é reconhecido pela UNESCO como um patrimônio da humanidade. Existe uma crescente conscientização sobre a importância da conservação desses recursos, uma vez que a Mata Atlântica, que apresenta uma biodiversidade tão rica quanto à floresta amazônica, está hoje reduzida a menos de $5 \%$ da sua extensão original e é um dos biomas mais ameaçados do planeta. A região também possự grande importância em termos étnicos e 
A região também possui grande importância em termos étnicos e culturais, pois habitam o Vale do Ribeira comunidades indígenas, caiçaras, remanescentes de quilombos e pequenos agricultores familiares, constituindo uma diversidade cultural raramente encontrada em locais tão próximos de regiões desenvolvidas (Capobianco, 1989; Lino, 1992). A preservação dos ecossistemas naturais, no entanto, restringe o uso econômico de diversas atividades na região, que se caracteriza por apresentar o menor desenvolvimento econômico do estado. As atividades econômicas da região encontram-se baseadas principalmente na agricultura (banana e chá), mineração e extrativismo vegetal (palmito), bem como a pesca comercial. A grande parcela da população vive em áreas rurais desenvolvendo atividades agrícolas de subsistência e extrativismo. Os parâmetros sócioeconômicos e demográficos, tais como mortalidade infantil, condições de habitação e niveis de renda e de escolaridade, contribuem para que a região apresente o menor índice de desenvolvimento humano (IDH) do estado (Hogan, 2002).

No período entre 1985 e 1996, a participação do Vale do Ribeira na produção industrial da indústria de transformação no estado de São Paulo nunca passou de $0,3 \%$. O levantamento da Secretaria de Ciência, Tecnologia e Desenvolvimento Econômico do Estado de São Paulo das decisões de investimentos privados em municípios do estado, anunciados entre 1995 e 1998, indicou que naquele periodo a situação não deveria mudar muito no futuro próximo. De um total de investimentos no estado no valor de US\$52 bilhões, o Vale do Ribeira contabilizou somente US\$23 milhões, em dois municípios, garantindo até hoje um relativo isolamento da região, ainda que sua capital regional, o município de Registro, encontre-se a apenas 200 km da Região Metropolitana de São Paulo (RMSP). Por outro lado, os aspectos econômicos desse sistema compreendem um grande potencial do ambiente geográfico para a produção de energia elétrica, agricultura, minério, lazer, turismo, pesquisa científica, pesca e abastecimento de água para São Paulo (Hogan, 2002).

As cidades do Vale do rio Ribeira de Iguape são atendidas pela SABESP, da mesma maneira que outras regiões do litoral e da região metropolitana de São Paulo, utilizando águas superficiais na captação, que são posteriormente tratadas por processo convencional. Os pontos críticos de coleta de água diferem de acordo com a peculiaridade de cada bacia, como uso e ocupação do solo, formação geológica, etc. 
Apesar de estar inserida em um estado que se caracteriza por apresentar um forte processo de urbanização e industrialização, a SABESP adota um modelo eficaz para a gestão dos recursos hídricos e a conseqüente preservação do meio ambiente em todo o Vale do Rio Ribeira de Iguape, por meio do uso de critérios de bacias hidrográficas que é aplicado a todo estado de São Paulo. A Lei Estadual $n^{\circ}$. 7.663/91 decretou a instalação do Comitê da Bacia Hidrográfica do Ribeira de Iguape e Litoral Sul - CBD RB, com o objetivo de gerenciar os recursos hídricos e sua preservação na Unidade de Gerenciamento de Recursos Hídricos (UGRHI-11), onde se encontram 18 ETAs operadas pela SABESP e que atendem parte do consumo de água tratada da região.

No entanto, avaliações realizadas nos últimos anos nos aqüíferos da região têm identificado diversas áreas críticas em termos de risco de potencial de contaminação. A CETESB constatou no ano de 1999 uma não conformidade de metais tóxicos (cobre e níquel), apesar de não relacionada às atividades mineradoras de Registro (CETESB, 1999; CETEC, 2001; Hogan, 2002). Identificou-se também uma redução da medida de condutividade, que deve estar associada a maior disponibilidade de água neste trecho. Por outro lado, a análise de coliformes fecais entre 1989 a 2000 indicou a ocorrência de lançamentos de esgotos domésticos clandestinos como o maior comprometimento das águas nessa cidade (CETESB, 2000).

Resultados do IAP (Índice de qualidade das águas para fins de abastecimento público) apontaram os rios Ribeira, Ribeira de Iguape e Juquiá como rios de qualidade boa (CETESB, 2004). No entanto, o rio Jacupiranga apresentou classificação regular, com teores elevados de alumínio, manganês, ferro e fósforo total, detectando-se toxidade para a Ceriodaphnia dúbia e indicando a necessidade de uma investigação mais profunda na região. Pontos de coleta no rio Ribeira de Iguape também apresentaram altas concentrações de fósforo, sendo que um ponto classificou-se como hipereutrófico.

Foi constatada também a presença de chumbo em sedimentos do rio Ribeira de Iguape, no trecho de lporanga, com provável origem nas antigas minerações de chumbo no Estado do Paraná. Foi encontrada uma concentração elevada do elemento (133mg.kg ${ }^{-1}$ ), superior a PEL (probabilidade de efeito severo à biota) e mais elevada do que os resultados de contaminantes em sedimentos obtidos em 2003. 
Apesar da maioria dos resultados dos testes de toxicidade indicar a ausência de substâncias tóxicas nas águas, é necessário se manter ações de monitoramento e controle, uma vez que a poluição das águas da região pode comprometer o abastecimento público de algumas cidades. Tal preocupação se justifica, por exemplo, quando se considera a carga estimada de lodos de ETA dos municípios da região lançados no Rio Ribeira de Iguape (TAB.14), que é a principal fonte de captação de água para abastecimento público da cidade de Registro. Tal constatação pode não ser tão preocupante em relação à quantidade de lodo produzido pela cidade de Iguape, cujo volume de residuos descartado é o maior da região, mas que se encontra na foz do rio Ribeira de Iguape, junto ao oceano.

TABELA 14: Produção estimada de lodo das ETAs no Vale do Ribeira (SABESP, 2003).

\begin{tabular}{|c|c|c|c|c|c|}
\hline Município & $\begin{array}{l}\text { Vazão } \\
\left(\mathrm{Ls}^{-1}\right)\end{array}$ & Coagulante & $\begin{array}{c}\text { Dosagem do } \\
\text { Coagulante }\end{array}$ & $\begin{array}{c}\text { Turbidez } \\
\text { (UT) }\end{array}$ & $\begin{array}{c}\text { Produção de } \\
\text { lodo (t) }\end{array}$ \\
\hline Juquiá & 42 & SA & 13 & 11 & 2,886 \\
\hline Tapiraí & 18 & SA & 10 & 9 & 0,989 \\
\hline Jacupiranga & 45 & SA & 15 & 13 & 3,622 \\
\hline Paiol do Meio & 10 & NAO & 0 & 9 & 0,350 \\
\hline Cananéia & 48 & SA & 13 & 7 & 2,552 \\
\hline Pedro de & 22 & SA & 46 & 6 & 2,533 \\
\hline São Lourenço & 16 & SA & 13 & 9 & 0,975 \\
\hline Miracatu & 33 & SA & 35 & 6 & 3,075 \\
\hline Registro & 155 & SA & 25 & 12 & 14,966 \\
\hline Juquitiba & 28 & SA & 15 & 10 & 1,927 \\
\hline Sete Barras & 36 & AS & 32 & 12 & 3,979 \\
\hline Pariqüiera- & 29 & AS & 52 & 10 & 4,137 \\
\hline Cajati & 66 & SA & 39 & 10 & 7,703 \\
\hline . Eldorado & 23 & AS & 32 & 10 & 2,363 \\
\hline Iporanga & 10 & AS & 17 & 9 & 0,689 \\
\hline Barra do & 9 & AS & 59 & 7 & 1,305 \\
\hline Iguape & 163 & AS & 26 & 11 & 15,430 \\
\hline Oliveira & 19 & $\mathrm{NAO}$ & 0 & 4 & 0,295 \\
\hline
\end{tabular}

*Sulfato de Alumínio. 
A cidade de Registro, porém, que apresenta um volume de lodo produzido bem próximo ao produzido por Iguape, lança seus despejos in natura em córregos no seu entorno e que são posteriormente despejados no rio Ribeira de Iguape. O rio Ribeira de Iguape ainda percorre cerca de $40 \mathrm{~km}$ até desaguar no oceano, sendo utilizado como fonte de captação de água. Se tradicionalmente no Brasil a preocupação em relação aos resíduos gerados em sistemas de saneamento era anteriormente restrita as estações de tratamento de esgotos, tem havido um maior questionamento em relação aos resíduos produzidos por estações de tratamento de água (PROSAB, 1999).

O município de Registro, principal cidade do Vale do Ribeira e que tem a maior população na UGRHI-11, possui uma ETA do tipo convencional que utiliza sulfato de alumínio como coagulante e cal para correção. Apresenta a maior carga estimada de lodos de ETA da região, que é despejada in natura nos rios da região.

\subsection{Condições ambientais}

O clima é influenciado pela distribuição da chuva, das temperaturas e dos ventos, afetando o processo de decomposição das rochas e erosão do solo, além do tipo de vegetação. Todas estas variáveis apresentam um efeito direto na qualidade das águas de captação e no seu posterior tratamento por uma ETA, de modo que algumas das principais propriedades encontradas no lodo resultante dos processos de tratamento de água podem ser influenciadas diretamente pelas condições ambientais da região. Por outro lado, o impacto do descarte do lodo proveniente dos decantadores e filtros pela ETA em cursos d'água localizados no seu entorno também poderá ser influenciado pela intensidade e freqüência do regime de chuvas, afetando a capacidade de acumulação e retenção destes resíduos e pelo aumento de temperatura observado durante alguns períodos em um ciclo hídrico, o que em geral pode acelerar processos bióticos e aumentar a capacidade de retenção de alguns metais (Salomons, 1995).

O clima do Vale do Ribeira pode ser classificado com características de tropical úmido, sem estação seca e com verão fresco, com uma pequena variação entre a zona litorânea e a crista da escarpa serrana, localmente denominada Serra de Paranapiacaba (Lemes, 2001). 
O clima úmido da região garante uma vegetação abundante, com baixas concentrações de sólidos na água e altos teores de compostos orgânicos. A temperatura média anual encontra-se ao redor de $21,5^{\circ} \mathrm{C}$ e o índice pluviométrico médio anual alcança $1.750 \mathrm{~mm}$, enquanto a umidade relativa do ar é normalmente ao redor de $70 \%$. No caso específico da cidade de Registro, a temperatura média anual em 2004 alcançou $22,7^{\circ} \mathrm{C}$ enquanto a precipitação média no mesmo periodo atingiu 115,2 mm (CIIAGRO, 2005).

Na TAB.15 é apresentada uma resenha das condições meteorológicas da cidade de Registro no periodo entre novembro de 2003 e fevereiro de 2005. Analisando-se o nível de precipitação média mensal, é evidente a identificação da temporada de chuvas entre os meses de novembro e fevereiro, além do periodo de estiagem entre agosto e setembro.

TABELA 15 - Resenha das condições ambientais da cidade de Registro, no periodo de Nov./2003 até Fev./2005 (CIIAGRO, 2005).

\begin{tabular}{|c|c|c|c|c|c|c|c|}
\hline $\begin{array}{l}\text { Período } \\
\text { (MÉs) }\end{array}$ & $\begin{array}{l}\text { Temperatura } \\
\text { Maxima } \\
\left.\text { Absoluta ( }{ }^{\circ} \mathrm{C}\right)\end{array}$ & $\begin{array}{l}\text { Temperatura } \\
\text { Minima } \\
\left.\text { Absoluta ( }{ }^{\circ} \mathrm{C}\right)\end{array}$ & $\begin{array}{l}\text { Temperatura } \\
\text { Maxima } \\
\left.\text { Mensal ( }{ }^{\circ} \mathrm{C}\right)\end{array}$ & $\begin{array}{l}\text { Temperatura } \\
\text { Minima } \\
\text { Mensal ('C) }\end{array}$ & $\begin{array}{l}\text { Temperatura } \\
\left.\text { madia ( }{ }^{\circ} \mathrm{C}\right)\end{array}$ & $\begin{array}{l}\text { Predpitaçäo } \\
\text { (mm) }\end{array}$ & $\begin{array}{c}\text { Dias } \\
\text { De } \\
\text { Chuva }\end{array}$ \\
\hline \multicolumn{8}{|c|}{ Ano de 2003} \\
\hline novembro & 40,4 & 12,8 & 28,7 & 18,9 & 23,8 & 118,6 & 12 \\
\hline dezembro & 39,3 & 14,6 & 29,9 & 20,7 & 25,3 & 123,4 & 15 \\
\hline \multicolumn{8}{|c|}{ Ano de 2004} \\
\hline janeiro & 36,6 & 16,5 & 27,7 & 20,4 & 24 & 408,4 & 16 \\
\hline fevereiro & 35,6 & 17,6 & 30,2 & 20,2 & 25,2 & 200,8 & 17 \\
\hline março & 35 & 15,6 & 28,7 & 19,6 & 24,2 & 152,9 & 16 \\
\hline abril & 34,4 & 15,2 & 28,7 & 19,9 & 24,3 & 77,9 & 13 \\
\hline maio & 29,5 & 7,4 & 23,6 & 15,6 & 19,6 & 78,8 & 14 \\
\hline junho & 28,4 & 5 & 23 & 14,7 & 18,9 & 43,1 & 7 \\
\hline julho & 31,5 & 9,4 & 22,3 & 14 & 18,2 & 120,7 & 14 \\
\hline agosto & 34,3 & 6,8 & 24,9 & 13,6 & 19,3 & 6,3 & 7 \\
\hline setembro & 38,8 & 12,5 & 27,2 & 17,7 & 22,4 & 18,1 & 7 \\
\hline outubro & 32,5 & 9,4 & 26,1 & 16,7 & 21,4 & 142,3 & 12 \\
\hline novembro & 35,3 & 14,4 & 27,7 & 19,3 & 23,5 & 142,4 & 15 \\
\hline dezembro & 35,2 & 15,5 & 28,5 & 19,9 & 24,2 & 351,8 & 22 \\
\hline \multicolumn{8}{|c|}{ Ano de 2005} \\
\hline janeiro & 37,2 & 18,5 & 28,9 & 21,6 & 25,2 & 428,6 & 20 \\
\hline fevereiro & 35,1 & 16,6 & 29,9 & 20,3 & 25,1 & 106,8 & 13 \\
\hline
\end{tabular}


O periodo de chuvas na região é caracterizado por provocar o transbordamento de rios e córregos, em especial da própria cidade de Registro, com conseqüentes transtornos à população ribeirinha, seja na área urbana ou rural (FIG.6 a 9). A Bacia Hidrográfica do Ribeira possui características peculiares em relação à possibilidade de ocorrência de cheias. As condições climáticas da região são altamente favoráveis à ocorrência de chuvas do tipo frontal, de grande intensidade e duração, que tendem a produzir grandes volumes de deflúvio superficial.

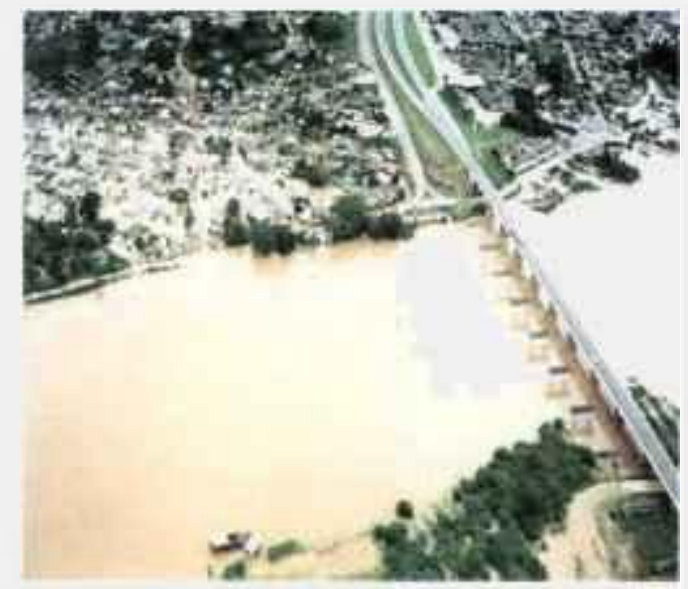

FIGURA 6

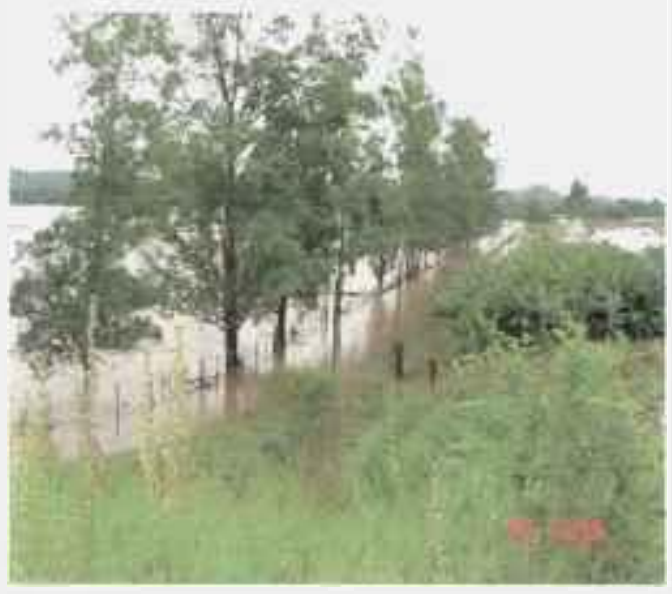

FIGURA 8

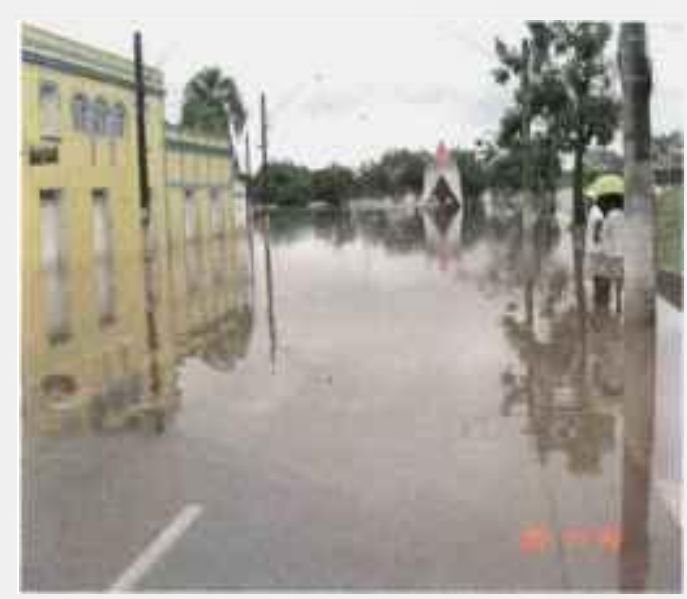

FIGURA 7

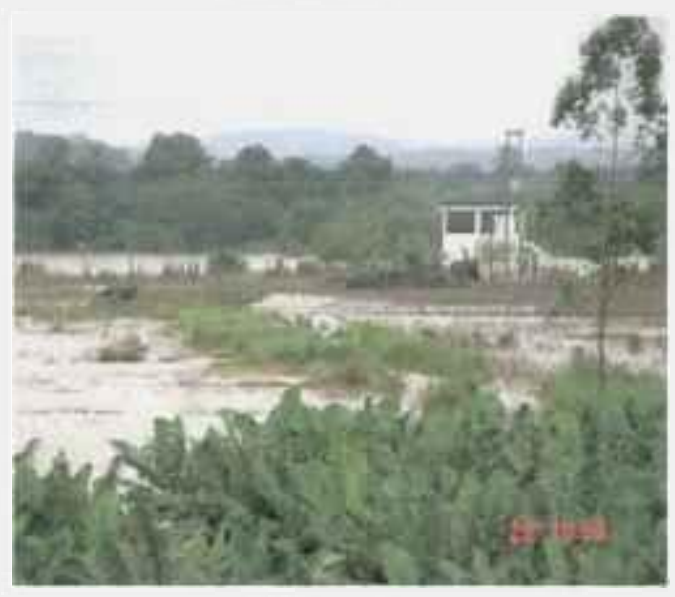

FIGURA 9

FIGURAS 6 a 9 - Representação fotográfica do período de cheia do rio Ribeira de Iguape, observado na região urbana (FIG.6 e 7) e rural (FIG.8 e 9). Ao fundo, na FIG.9, observa-se a estação de captação de água de ETA de Registro, às margens do rio Ribeira de Iguape. 
As características geomorfológicas da bacia também favorecem a ocorrência de grandes cheias. No trecho superior e médio, o rio Ribeira e seus afluentes correm por vales encaixados, com uma declividade média muito elevada.

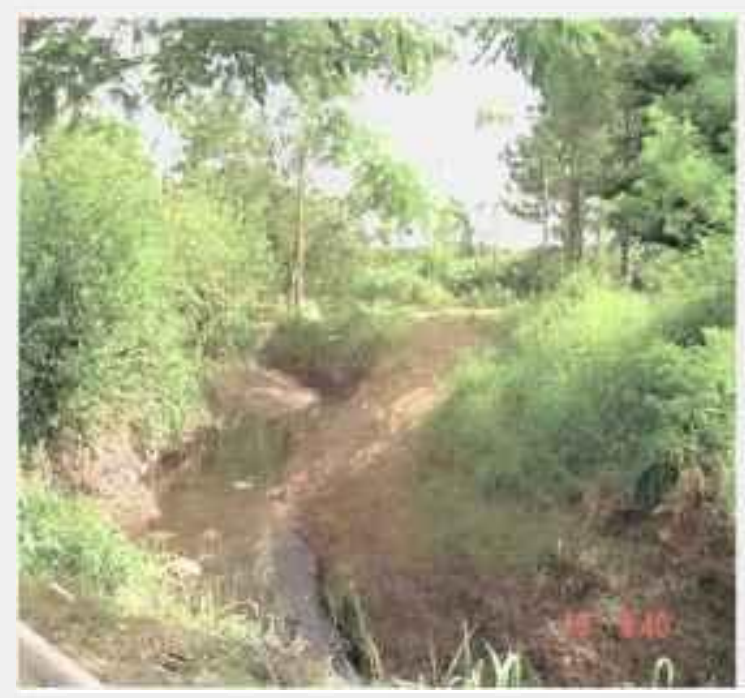

FIGURA 10

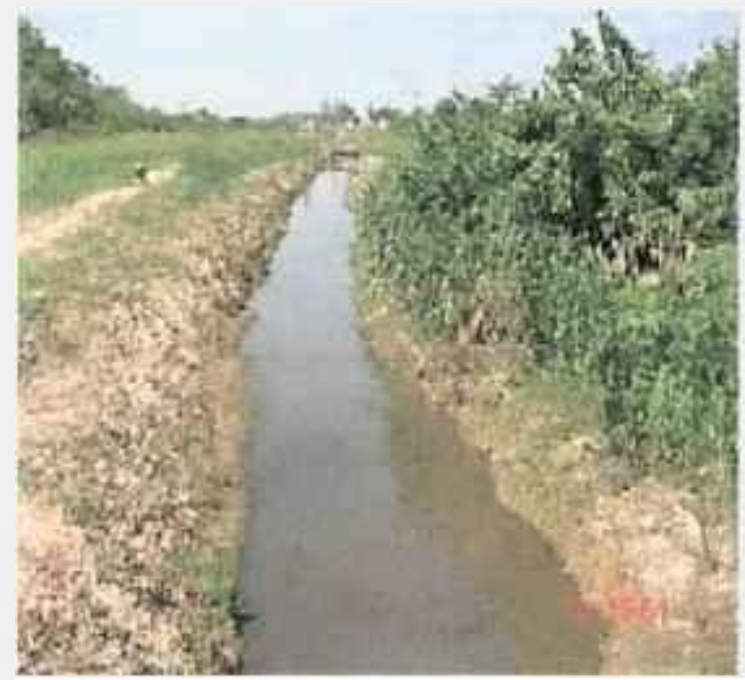

FIGURA 12

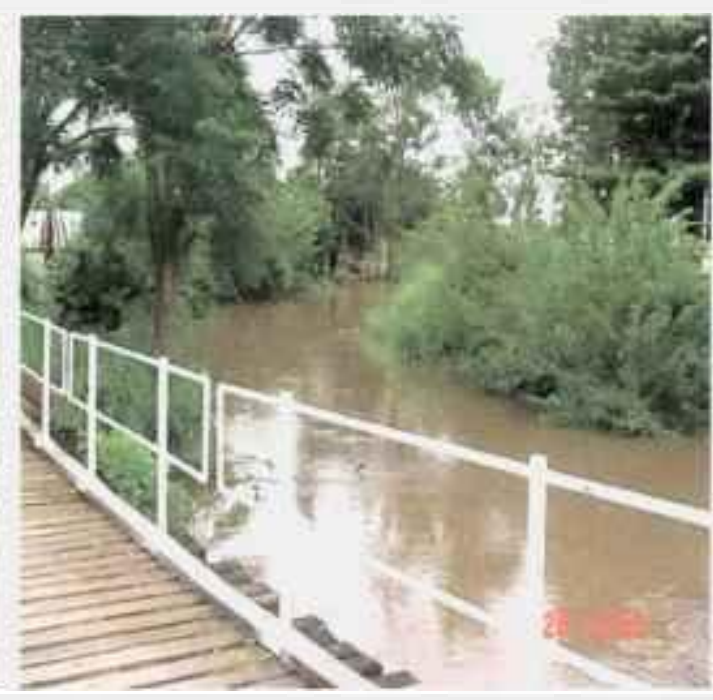

FIGURA 11

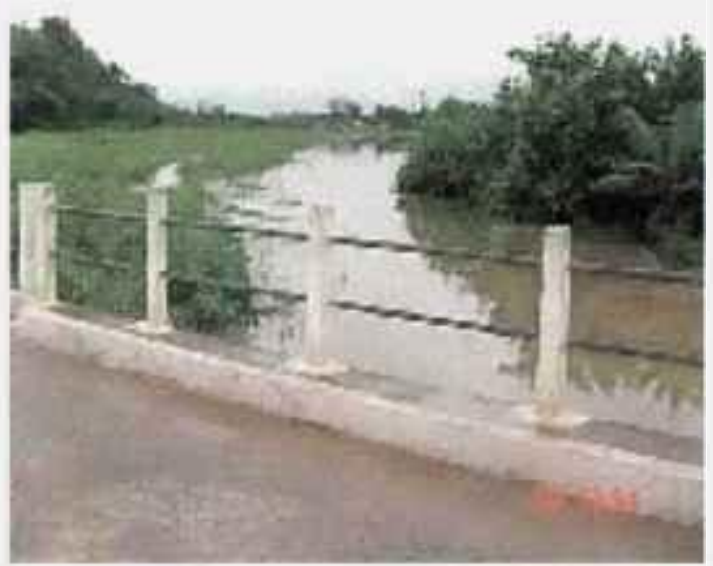

FIGURA 13

FIGURAS 10 a 13 - Variação observada no ano de 2003 nos mesmos locais no Ribeirão de Registro (FIG.10 e 11) e no rio Sem Nome (FIG.12 e 13), na cidade de Registro, nos períodos de estiagem e chuvas, respectivamente. 
No curso inferior, à jusante de Eldorado e após receber a contribuição do rio Juquiá, o rio Ribeira do Iguape apresenta-se como um rio típico de planície, recortando terrenos alagadiços de baixada, com declividade praticamente nula. A superposição desses dois fatores constitui a causa básica das cheias de grande magnitude, tanto em termos de vazão de pico como de volume. O trecho inferior da bacia é o que sofre as maiores conseqüências, em virtude das características geomorfológicas citadas.

Embora o índice pluviométrico seja menor nas outras estações do ano, também podem ser observados transbordamentos no rio Ribeira de Iguape no período de julho a agosto de 2004. As cheias do Ribeira de Iguape geram grandes impactos, com prejuízos com a inundação de habitações, estabelecimentos comerciais, e perda da produção agrícola, com graves conseqüências econômicas e sociais (DAEE, 1998). Córregos e pequenos rios que percorrem tanto a área rural quanto à área urbana são também passíveis de inundações. 


\subsection{Materiais e métodos}

\subsubsection{Equipamentos e materiais}

- Espectrômetro de emissão óptica com fonte de plasma de argônio induzido (ICPOES), Espectro Flame M 120, Spectro Analytical Instruments; equipado com uma tocha axial, nebulizador concêntrico Meinhard e câmara de spray tipo Scott;

- Espectrômetro de Fluorescência de Raios X por Dispersão de Comprimento de Onda, Modelo RIX 3000, Rigaku;

- Espectrômetro de Absorção Atômica (forno de grafita) - Perkin Elmer Analyst 800;

- Centrifuga Fanen - modelo 240;

- Sistema digestor por microondas, Provecto Analytical - DGT - 100 Plus;

- Agitador mecânico horizontal, Ética - modelo 340;

- Potenciômetro de Campo, Digimed - modelo 330;

- Sistema de purificador de água Easypure RF, Barnstead;

- Sistema de filtração de soluções em membrana a vácuo, Sartorius;

- Membrana $47 \mathrm{~mm}(0,45 \mu \mathrm{m})$, Millipore;

- Balança analítica - Micronal BG 400;

- Estufa Fanen;

- Micropipetas (Finnpipette Labsystems);

- Frascos de polietileno diversas capacidades e vidraria em geral.

\subsubsection{Reagentes e soluções}

Todos os ácidos utilizados foram de grau analítico (Merck, Baker ou similar). As soluções padrão multi-elementares, contendo os elementos-traço utilizados (com o propósito de padronização do método) nas análises do ICP-OES, foram preparadas em meio $5 \%(\mathrm{v} / \mathrm{v}) \mathrm{HNO}_{3}$, de acordo com soluções padrão de referência com certificado de pureza (Merck) com concentração certificada de $1.000 \mathrm{mg} \cdot \mathrm{L}^{-1}$. 
As soluções padrão multi-elementares foram preparadas a partir dos seguintes analitos: Alumínio (Al), Bário (Ba), Boro (B), Cádmio (Cd), Cálcio $(\mathrm{Ca})$, Chumbo $(\mathrm{Pb})$, Cromo $(\mathrm{Cr})$, Cobalto $(\mathrm{Co})$, Cobre $(\mathrm{Cu})$, Estrôncio $(\mathrm{Sr})$, Fósforo $(\mathrm{P})$, Ferro $(\mathrm{Fe})$, Magnésio $(\mathrm{Mg})$, Manganês $(\mathrm{Mn})$, Molibdênio (Mo), Níquel $(\mathrm{Ni})$, Potássio $(\mathrm{K})$, Prata $(\mathrm{Ag})$, Sódio $(\mathrm{Na})$, Vanádio (V) e Zinco (Zn). As calibrações foram executadas com a diluição das soluções multi-elementares para concentrações apropriadas e todos os reagentes usados foram de grau analítico.

\subsubsection{Determinação de metais e elementos traço por ICP-OES}

As determinações dos analitos foram realizadas utilizando-se a espectrometria de emissão óptica com fonte de plasma de argônio induzido (ICP-OES). Esta técnica é amplamente utilizada para análises ambientais (Charles \& Fredeen, 1997), por ser uma técnica multielementar que permite a determinação simultânea de seus constituintes maiores, menores e traço.

Foram elaborados programas analíticos para a determinação de todos os elementos de interesse. Foram escolhidas as linhas de emissão para cada elemento, levando-se também em conta possiveis interferências do efeito da matriz (Schramel, 1988; Lemes, 2001). Os principais parâmetros operacionais estão listados na TAB.16.

O método da curva analitica foi utilizado na determinação dos elementos por meio do uso de soluções padrão multi-elementares diluídas em solução de ácido nítrico a $2 \%$, a partir de soluções originais de $1000 \mathrm{mg} \cdot \mathrm{L}^{-1}$. As curvas analíticas obtidas são representadas pela equação da reta ou regressão linear, e a concentração de cada analito é dada pela equação (6) (Charles \& Fredeen, 1997; Santos, 1999):

$$
\text { Concentração do analito (mg. } \left.\mathrm{L}^{-1}\right)=\mathrm{Ao}+\mathrm{Al} \text {. Ir }
$$

onde: $A o=$ coeficiente linear;

A1 = coeficiente angular da regressão;

Ir $=$ intensidade relativa da emissão do analito. 
TABELA 16. Condições de operação do sistema (ICP-OES).

\begin{tabular}{lc}
\hline \multicolumn{1}{c}{ Parâmetros Instrumentais } & Condições \\
Potência Incidente do Plasma & $1,2 \mathrm{~kW}$ \\
Gás refrigerante (Ar) & $28 \mathrm{~L} \cdot \mathrm{min} .^{-1}$ \\
Vazão do gás do plasma (Ar) & $7,0 \mathrm{~L} \cdot \mathrm{min} .^{-1}$ \\
Vazão do gás auxiliar (Ar) & $15 \mathrm{~L} \cdot \mathrm{min} .^{-1}$ \\
Fluxo de amostra & $2,0 \mathrm{~mL} \cdot \mathrm{min}^{-1}$ \\
Tempo de pré-fluxo & $40 \mathrm{~s}$ \\
\hline
\end{tabular}

As linhas selecionadas para as medidas, bem como os parâmetros para as curvas analíticas estão listados na TAB.17.

De acordo com Thompson (1987), o limite de quantificação instrumental é definido como a menor concentração do analito que pode ser determinada com um nível aceitável de precisão e veracidade. Na prática, equivale ao padrão de calibração de menor concentração, excluindo o branco. A determinação do limite de deteç̧ão instrumental calculado pelo software geralmente é muito "otimista" quando comparado com o limite de detecção prático.

Para maior segurança, foram usados limites de quantificação que diferem de 2 a 5 vezes do limite de deteç̧ão instrumental (Thompson, 1987; SPECTRO, 1999). 
TABELA 17. Linhas de emissão, intervalo de linearidade e limite de quantificação dos elementos analisados para a determinação por ICP- OES das amostras de águas superficiais e sedimentos de coletas dos cursos d'água receptores do lodo da ETA.

\begin{tabular}{|c|c|c|c|c|c|c|}
\hline & \multicolumn{3}{|c|}{ Águas Superficiais } & \multicolumn{3}{|c|}{ Sedimentos } \\
\hline Analito & $\begin{array}{l}\text { L. E. } \\
(\mathrm{nm})\end{array}$ & $\begin{array}{c}\text { I. L. } \\
\left.\text { (mg.L }{ }^{-1}\right)\end{array}$ & $\begin{array}{c}\text { L. Q. } \\
\left.\text { (mg. } \text { L }^{-1}\right)\end{array}$ & $\begin{array}{l}\text { L. E. } \\
(\mathrm{nm})\end{array}$ & 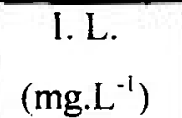 & $\begin{array}{c}\text { L. Q. } \\
\left.\text { (mg. } \mathrm{L}^{-1}\right)\end{array}$ \\
\hline$\overline{\mathrm{Ag}}$ & 328,068 & $0,003-6$ & 0,003 & - & - & - \\
\hline$\overline{\mathrm{Al}}$ & 167,083 & $0,0005-1,2$ & 0,0005 & 256,798 & $0,086-120$ & 0,086 \\
\hline B & 249.773 & $0,004-1.2$ & 0.004 & $\overline{-}$ & $\overline{-}$ & - \\
\hline $\mathrm{Ba}$ & 455,403 & $0,00003-12$ & 0,00003 & 455,403 & $0,0004-24$ & 0,0004 \\
\hline $\mathrm{Ca}$ & 315,887 & $0,006-12$ & 0,006 & 370,603 & $0,022-120$ & 0,022 \\
\hline $\mathrm{Cd}$ & 228,802 & $0,0001-1,2$ & 0,0001 & 228,802 & $0,0002-1,2$ & 0.0002 \\
\hline $\mathrm{Co}$ & 231,498 & $0,005-12$ & 0,005 & 238,636 & $0,003-12$ & 0,003 \\
\hline$\overline{\mathrm{Cr}}$ & 267.716 & $0,0004-1.2$ & 0.0004 & 267,716 & $0,001-1.2$ & 0,001 \\
\hline $\mathrm{Cu}$ & 324.754 & $0,003-1.2$ & 0,003 & 327,396 & $0,001-12$ & 0.001 \\
\hline $\mathrm{Fe}$ & 261.187 & $0,006-1.2$ & 0.006 & 273,074 & $0,109-120$ & 0,109 \\
\hline$\overline{\mathbf{K}}$ & 766,491 & $0,0001-12$ & 0,0001 & 766,491 & $0,002-60$ & $\overline{0,002}$ \\
\hline $\mathrm{Mg}$ & 383,826 & $0,006-12$ & $\overline{0.006}$ & 279,079 & $0,007-60$ & 0,007 \\
\hline$\overline{M n}$ & 257,610 & $0,0001-1.2$ & 0,0001 & 280.106 & $0,003-60$ & 0,003 \\
\hline Mo & 202,030 & $0,002-1.2$ & 0.002 & 386,411 & $0,012-6$ & 0,012 \\
\hline$\overline{\mathrm{Na}}$ & 589,592 & $0,002-24$ & 0.002 & 589.592 & $0,046-60$ & $\overline{0,046}$ \\
\hline $\mathrm{Ni}$ & 231.604 & $0.002-1.2$ & $\overline{0.002}$ & 341,476 & $0,010-1.2$ & 0.010 \\
\hline $\mathbf{P}$ & 177.500 & $0,004-12$ & 0.004 & 177,500 & $0,003-12$ & 0.003 \\
\hline$\overline{\mathrm{Pb}}$ & * & F & * & 220,353 & $0,007-12$ & 0,007 \\
\hline $\mathrm{Sb}$ & - & - & - & - & - & - \\
\hline $\mathrm{Si}$ & - & - & - & 212.412 & $0,166-12$ & 0.166 \\
\hline Sn & 283,999 & $0,020-1,2$ & 0.020 & 283,999 & $0.0012-6$ & 0,001 \\
\hline $\mathrm{V}$ & 290,882 & $0,007-1.2$ & 0.007 & 290,882 & $0,006-6$ & 0,006 \\
\hline$\overline{\mathrm{Zn}}$ & 213.856 & $0,0001-1.2$ & 0.0001 & 334,502 & $0,019-30$ & 0,019 \\
\hline
\end{tabular}

L.E. - Linha de Emissão $(\lambda-\mathrm{nm})$.

I.L.: Intervalo de Linearidade (mg. $\left.\mathrm{L}^{-1}\right)$.

LQ: Limite de Quantificação (mg.L $\left.{ }^{-1}\right)$. 


\subsubsection{Validação da metodologia}

O controle de qualidade analítico baseou-se em análises diárias de soluções padrão e análise em triplicata das amostras. A validação da metodologia analítica foi efetuada pela análise de material de referência certificado NIST (National Institute of Standards and Technology, Gaithersburg, MA, USA): SRM 1643c (Trace Elements in Water), para a análise de água e padrão de sedimento NIST SRM 2704 (Buffalo River Sediment), para avaliação do procedimento de lixiviação em sedimentos (Cotrim, 2004, 2005).

Uma comparação entre os valores certificados e os determinados para os materiais de referência analisados em águas superficiais é apresentada na TAB.18, mostrando a reprodutibilidade da metodologia aplicada.

TABELA 18 - Reprodutibilidade, precisão e desvio padrão relativo para a análise do material de referência SRM-1643c, por ICP-OES. (Cotrim, 2004, 2005).

\begin{tabular}{|c|c|c|c|c|}
\hline Elemento & $\begin{array}{c}\text { Valor } \\
\text { Certificado } \\
\left(\mathrm{mg} . \mathrm{L}^{-1}\right)\end{array}$ & $\begin{array}{l}\text { Valor Obtido } \\
\quad\left(\mathrm{mg} \cdot \mathrm{L}^{-1}\right)\end{array}$ & $\begin{array}{c}\text { Desvio padrão } \\
\text { relativo (\%) }\end{array}$ & $\begin{array}{c}\text { Recuperação } \\
\text { (\%) }\end{array}$ \\
\hline $\mathrm{Al}$ & 114,6 & 114 & 0,9 & 99,9 \\
\hline $\mathrm{Ba}$ & 49,6 & 37,9 & 0,5 & 76,4 \\
\hline $\mathrm{Ca}$ & 36.800 & 37.500 & 0,5 & 102 \\
\hline $\mathrm{Cd}$ & 12,2 & 13,3 & 1,5 & 109 \\
\hline Co & 23,5 & 23 & 4,3 & 97,8 \\
\hline $\mathrm{Cr}$ & 22,3 & 20 & 5 & 88,8 \\
\hline $\mathrm{Cu}$ & 19,0 & 17 & 12 & 89,3 \\
\hline$\overline{\mathrm{Fe}}$ & 106,9 & 100 & 2 & 93,8 \\
\hline $\mathrm{Mg}$ & 9.400 & 8.700 & 0,5 & 92,7 \\
\hline$\overline{\mathrm{Mn}}$ & 35,1 & 36 & 2,8 & 103 \\
\hline $\mathrm{Ni}$ & 60,6 & 53 & 4 & 88,2 \\
\hline $\mathrm{Zn}$ & 73,9 & 72 & $1, \overline{4}$ & 97,9 \\
\hline
\end{tabular}




\subsection{Reconhecimento da Área}

\subsubsection{Análise das condições climáticas}

A análise das condições climáticas da região foi realizada avaliando-se o banco de dados do Centro Integrado de Informações Agrometeorológica (CIIAGRO), na resenha agrometeorológica, no item lista consulta por Unidade de Gerenciamento dos Recursos Hídricos (CIIAGRO, 2005). O CIIAGRO foi criado em $1998 \mathrm{com}$ a finalidade de operacionalizar e disponibilizar informações e aconselhamento às atividades agrícolas com base nos parâmetros agrometeorológicos e previsão do tempo. Dados como temperatura e precipitação acumulada são coletados duas vezes por semana. Para este trabalho, foram consultados os dados do município de Registro.

O período de monitoramento correspondeu inicialmente ao periodo de chuvas, abrangendo posteriormente a toda estação de chuvas e de estiagem, de novembro de 2003 a agosto de 2004. Foram avaliados os parâmetros de pluviosidade e temperatura média da região, bem como a turbidez da água de captação. Estes últimos resultados foram relacionados com a quantidade média de coagulante utilizado pela ETA e com os resultados obtidos nas análises do lodo recolhido nos tanques de decantação.

\subsubsection{Caracterização do sistema de tratamento de água}

A caracterização física e operacional da ETA de Registro foi realizada por meio de visitas técnicas e do levantamento de informações a partir do banco de dados diários do acervo da própria ETA. Informações sobre os valores de vazão, consumo dos produtos químicos, dados operacionais e características da água foram obtidas junto ao Departamento Técnico e Controle Sanitário da Unidade de Negócio do Vale do Ribeira, da Companhia de Saneamento Básico de São Paulo - SABESP.

O sistema de tratamento de água de Registro opera com uma capacidade nominal de 155 a 180 L.s ${ }^{21}$. Foi projetado com 2 módulos, cada um contendo um decantador, 4 filtros e 2 floculadores hidráulicos. Depois da captação, é adicionado sulfato de alumínio à água, passando pelo tanque de coagulação e posteriormente pela floculação. 
Após estes tanques, a água segue para o decantador onde as partículas sólidas decantam e a água clarificada passa para a fase de filtração. Em seguida, esta água segue para a câmara de contato com a adição de ácido fluorsilícico, onde finalmente se encontra em condições de ser distribuida para a população. Na TAB.19 é apresentado um resumo identificando informações sobre a área de captação, as características da ETA e do Corpo Receptor dos efluentes, além da sua localização geográfica.

TABELA 19. Caracterização da Área de Estudo: ETA, ETE, captações, corpo receptor e observações relevantes. (Fonte: Laboratório de Controle Sanitário da SABESP, Registro).

\begin{tabular}{|c|c|c|c|}
\hline $\begin{array}{c}\text { Município } \\
\text { Código Controle } \\
\text { Sanitário } \\
\text { SABESP }\end{array}$ & $\begin{array}{l}\text { População } \\
\text { Total / } \\
\text { Urbana } \\
\text { (Hab)' }\end{array}$ & $\begin{array}{l}\text { Informaçōes sobre Captação e } \\
\text { Características da ETA e do Corpo } \\
\text { Receptor de Resíduos e Localização dos } \\
\text { pontos (GPS) }\end{array}$ & $\begin{array}{c}\text { Características das } \\
\text { ETEs e } \\
\text { Corpos Receptores efluentes }\end{array}$ \\
\hline $\begin{array}{l}\text { Registro } \\
\text { LR - 00I }\end{array}$ & $\begin{array}{l}53.505 \text { hab } \\
42.853 \text { hab }\end{array}$ & $\begin{array}{l}\text { Captação: Rio Ribeira de Iguape. } \\
\text { S: } 24^{0} 28^{\prime} 24,5^{\circ} \\
\text { O: } 47^{\circ} 50^{\prime} 36,2^{\prime \prime} \\
\text { ETA convencional, } 1881 / \mathrm{s} \\
\text { Início de Operação: } 1994 \\
\text { S: } 24^{0} 29^{\prime} 05.5^{\prime \prime} \\
\text { O: } 47^{0} 50^{\circ} 58,9^{\prime \prime} \\
\text { Índice de atendimento atual: } \\
\text { Água de abastecimento - } 100 \% \\
\text { Coleta de esgoto - } 71 \% \\
\text { Tratamento de esgoto - } 98 \% \\
\text { Corpo receptor do Lodo de ETA e } \\
\text { resíduos de lavagem des filtros: } \\
\text { Rio Sem Nome } \\
\text { ( Município de Registro) }\end{array}$ & $\begin{array}{l}\text { ETE: Lagoa Anaeróbia em } \\
\text { série com Lagoa Facultativa } \\
\text { Índice de atendimento atual: } \\
\text { Coleta de esgoto - } 71 \% \\
\text { Tratamento de esgoto - } 98 \% \\
\text { Corpo receptor do efluente da } \\
\text { ETE: } \\
\text { Rio Ribeira de lguape } \\
\text { ( Municipio de Registro) }\end{array}$ \\
\hline
\end{tabular}

Fonte: SABESP- Unidade de Negócio Vale do Ribeira; CETESB. ${ }^{\prime \prime}$

GPS: Global Positioning System ( Latitude S- Sul, Longitude O-Oeste) ${ }^{(2)}$.

A limpeza dos decantadores é realizada periodicamente em intervalos de tempo de aproximadamente 30 dias. O processo utiliza remoção descontínua de lodo e limpeza manual. As comportas de entrada da água decantada são fechadas e as adufas de fundo são abertas para a remoção do material retido no tanque. O lodo é lançado no rio denominado "Sem Nome" por meio de uma tubulação de $5 \mathrm{~m}$ de diâmetro em concreto armado, com cerca de 200 m de comprimento. Este rio recebe como afluente o Ribeirão de Registro que 
deságua no Rio Ribeira de Iguape. A operação de limpeza dos decantadores leva em média 4 horas, auxiliada com jatos de água sob pressão e resultando em uma vazão de cerca de 100 L.s ${ }^{-1}$. Como o lodo é descartado com uma periodicidade de uma vez por mês, este fato definiu o período de coleta.

\subsection{Caracterização das variáveis físico-químicas}

\subsubsection{Caracterização do lodo da ETA}

A caracterização das variáveis físico-quimicas do lodo foi executada nas amostras recolhidas nos decantadores da estação de tratamento de água e nos sistemas de filtração. Neste estudo foram avaliados os parâmetros físico-quimicos como $\mathrm{pH}$, alcalinidade, cor, turbidez, densidade, sólidos sedimentáveis, sólidos totais, fixos e voláteis, metais, macro e micro-constituintes (APHA, 1995). Foi determinada a estabilidade do lodo frente a agentes agressivos, visando biodisponibilidade dos metais. Foram estudados processos de lixiviação em meio levemente ácido, visando conhecer a estabilidade dos flocos de resíduos e verificando que fração deste poderia estar disponível ao ambiente aquático.

Os lodos provenientes dos decantadores foram caracterizados levando-se em conta a sua composição básica. O lodo foi caracterizado após uma amostragem composta realizada no fundo dos decantadores e que consiste na coleta pontual de pequena quantidade do lodo, dividindo-se a área total do fundo do tanque de decantação de $1 \mathrm{em} 1 \mathrm{~m}^{2}$. Cada amostra coletada foi acondicionada em um tambor e homogeneizada, sendo deste retirada uma amostra de 2 litros. Nas FIG.14 e 15 são apresentadas as etapas de coleta do lodo, realizada em um dos dois tanques de decantação da ETA.

Quanto à periodicidade de amostragens, foram realizadas quatro coletas entre o período de novembro de 2003 e setembro de 2004, sendo a primeira de caráter preliminar. As coletas tiveram o objetivo de avaliar possiveis alterações na composição do lodo nas diferentes estações de seca e chuva (Schimitt, 1975; Lemes, 2001). Após as coleta, as amostras foram filtradas, secas a temperatura de $55-65^{\circ} \mathrm{C}$ e peneiradas (granulometria $<63$ $\mu \mathrm{min)}$. 


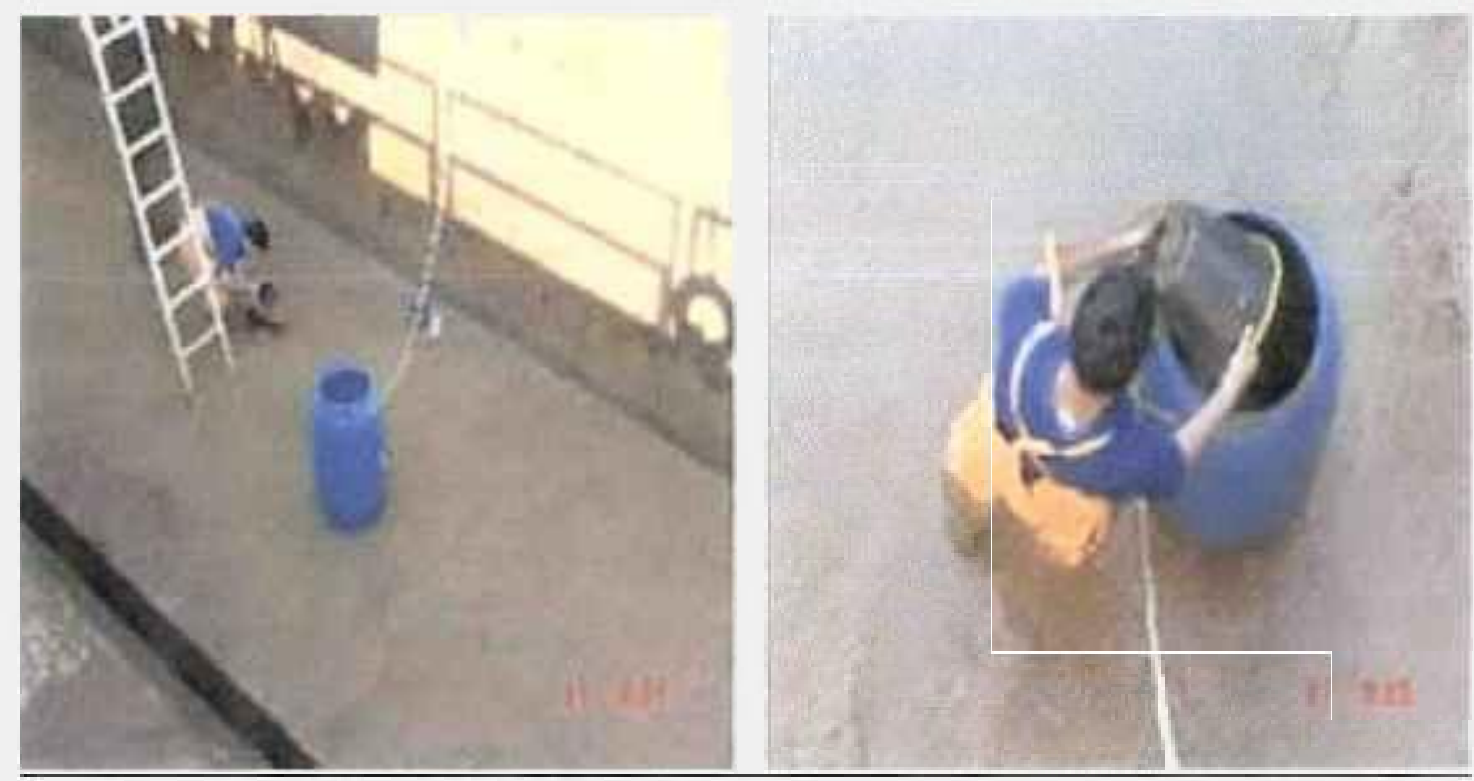

FIGURAS 14 e 15 - Coleta de amostras de lodo de ETA no tanque de decantação, seguido de homogeneização para amostra representativa.

As caracterizações química e geomorfológica das amostras foram realizadas utilizando as técnicas de fluorescência de raios X (FRX), difração de raios X (DRX) e microscopia eletrônica de varredura (MEV). Uma análise química semi-quantitativa foi realizada em uma amostra de lodo previamente calcinada a $900^{\circ} \mathrm{C}$, utilizando-se espectrometria de fluorescência de raios X. A validação da metodologia utilizando a técnica de FRX foi efetuada pela análise de material de referência RM2704, de acordo com a TAB.20.

A determinação da concentração do teor total de metais presentes no lodo, tanto por meio da técnica de FRX quanto por DRX, podem não corresponder necessariamente à porção mais disponível desses metais para incorporação à biota (biodisponibilidade). Metais tóxicos podem estar encapsulados em estruturas de quartzo ou outros minerais quimicamente inertes. A determinação de metais associados às frações dissolvidas geralmente fornece mais informação para se estimar prováveis efeitos tóxicos desses elementos (Fiszman, 1984). Neste sentido, técnicas de extração para a determinação do teor total e parcial de metais foram conduzidas utilizando-se métodos EPA (USEPA, 1996). 
TABELA 20 - Teores certificados e determinados por Espectrometria de Fluorescência de Raios X por dispersão de comprimento de onda para o material de referência CRM-2704 Buffalo River Sediment (NIST) (Scapin, 2003).

\begin{tabular}{|c|c|c|c|}
\hline & \multicolumn{3}{|c|}{ Concentração (\%) } \\
\hline $\begin{array}{c}\text { Elemento } \\
\%\end{array}$ & $\begin{array}{c}\text { Valor } \\
\text { Certificado } \\
\left(x_{\text {ten }} \pm \sigma_{\text {ten }}\right)\end{array}$ & $\begin{array}{c}\text { Valor } \\
\text { Determinado } \\
\left(\bar{x}_{\text {det }} \pm \sigma_{\text {det }}\right)\end{array}$ & $\begin{array}{l}\text { c.v } \\
(\%)\end{array}$ \\
\hline $\mathrm{SiO}_{2}$ & $62,21 \pm 0,13$ & $62.8+0,2$ & 0,95 \\
\hline $\mathrm{TiO}_{2}$ & $0,76 \pm 0,02$ & $0,79 \pm 0,01$ & 3,9 \\
\hline $\mathrm{Al}_{2} \mathrm{O}_{3}$ & $11,5 \pm 0,2$ & $11,48 \pm 0,04$ & 0,52 \\
\hline $\mathrm{Fe}_{2} \mathrm{O}_{3}$ & $5,9 \pm 0,1$ & $5,87 \pm 0,07$ & 0,2 \\
\hline $\mathrm{MnO}$ & $0,07 \pm 0,01$ & $0,073 \pm 0,005$ & 4,3 \\
\hline $\mathrm{MgO}$ & $1,99 \pm 0,02$ & $1,93 \pm 0,03$ & 3,0 \\
\hline $\mathrm{CaO}$ & $3,64 \pm 0,03$ & $3,82 \pm 0,03$ & 4,9 \\
\hline $\mathrm{Na}_{2} \mathrm{O}$ & $1,44+0,01$ & $1,50 \pm 0,01$ & 4,2 \\
\hline $\mathrm{K}_{2} \mathrm{O}$ & $1,66 \pm 0,04$ & $1,59 \pm 0,01$ & 4,2 \\
\hline $\mathrm{P}_{2} \mathrm{O}_{5}$ & $0,23 \pm 0,03$ & $0,235 \pm 0,005$ & 2,2 \\
\hline
\end{tabular}

Para a caracterização química do lodo foi utilizada como ferramenta analítica, a técnica de espectrometria de emissão com fonte de plasma induzido (Spectroflame, M 120), com sistema de nebulizador ultrassônico. As amostras de lodo foram previamente secas, peneiradas e subdivididas em três frações para a determinação da concentração total, parcial e lixiviável dos metais e demais constituintes. Foram adotados os métodos EPA SW 8463052, para a digestão total e SW 846-3051-A, para a digestão parcial.

Os métodos consistem na utilização de meios distintos de digestão ácida em forno microondas (sistema fechado) para matrizes orgânicas (digestão parcial) e matrizes orgânicas e silicosas (digestão total). O método EPA 3052 corresponde à digestão total da amostra, com uma mistura $\mathrm{HNO}_{3} / \mathrm{HF}$. O método EPA 3051 consiste em usar uma mistura do ácido nítrico $\left(\mathrm{HNO}_{3}\right)$ e ácido clorídrico $(\mathrm{HCl})$, avaliando-se metais associados às fases inorgânicas e orgânicas, porém com um ataque mínimo à fração silicato. $\mathrm{OHNO}_{3}$ promove uma destruição completa dos compostos orgânicos (Kingston, 1997; Lemes, 2001) e causa um menor efeito de matriz nas técnicas espectrométricas. 
A fração de elementos lixiviáveis foi obtida em $\mathrm{HCl} 0,1 \mathrm{M}$, utilizando agitação mecânica de $0,3 \mathrm{~g}$ de amostra, por 2 horas a $150 \mathrm{RPM}$ e com $50 \mathrm{~mL}$ de solução de $\mathrm{HCl}$ $0,1 \mathrm{M}$, seguido de filtração em papel Whatman $\mathrm{n}^{\circ} .42$ e acondicionamento em frascos plásticos apropriados (Gatti, 1997; Lemes, 2001; Katsuoka, 2001). Este processo permite liberar elementos associados com as frações trocáveis, carbonatos, óxidos de ferro e manganês, além de matéria orgânica (Rauret, 1998).

\subsubsection{Caracterização físico-química da água no sistema de tratamento e no processo de descarte do lodo}

A caracterização das variáveis fisico-químicas da água foi realizada em todo o processo de tratamento, avaliando-se a ocorrência de metais solúveis na água e estabelecendo-se um perfil da ETA no dia da lavagem do decantador e do descarte do lodo. Foram coletadas amostras na área de captação (rio Ribeira de Iguape), na entrada da água no sistema, no tanque de floculação e no tanque de decantação, conforme mostrado na TAB.21.

O processo de despejo do lodo da ETA também foi monitorado, coletando-se amostras de hora em hora, num total de dez amostras, na saída do cano de descarte do lodo da ETA, às margens do rio Sem Nome. A primeira amostra foi coletada no momento inicial da abertura das válvulas de saída do decantador, isto é, quando se inicia o processo de descarte. Os parâmetros avaliados neste estudo estão descritos na TAB.22. Essas variáveis foram selecionadas levando-se em conta a Resolução 357/2005, a Portaria 8648 e a Portaria 518.

TABELA 21 - Identificação dos pontos de coleta.

\begin{tabular}{|l|l|}
\hline \multicolumn{1}{|c|}{ Denominação } & \multicolumn{1}{c|}{ Local } \\
\hline ETA 1 - Água bruta & Captação do Rio Ribeira de Iguape \\
\hline ETA 2 - Água bruta & Ramificação da adutora \\
\hline ETA 3 - Água coagulada & Tanque de floculação \\
\hline ETA 4 - Água decantada & Tanque de decantação \\
\hline
\end{tabular}


TABELA 22. - Parâmetros para a avaliação das amostras de efluentes da ETA (APHA/AWWA/WEF 1998).

\begin{tabular}{|c|c|c|}
\hline PARÂMETROS & MÉTODO & EQUIPAMENTO \\
\hline $\mathrm{pH}$ & Eletrométrico & pHmetro, Dm 20, Digimed \\
\hline Turbidez & Nefelométrico & $\begin{array}{c}\text { Turbidímetro, B 250, } \\
\text { Micronal }\end{array}$ \\
\hline $\begin{array}{c}\text { Metais e elementos - traço } \\
\mathrm{Na}, \mathrm{Mg}, \mathrm{Ca}, \mathrm{P}, \mathrm{K}, \mathrm{Fe}, \mathrm{Al}, \mathrm{Mn}, \mathrm{Ba} \text {, } \\
\mathrm{Co}, \mathrm{B}, \mathrm{V}, \mathrm{Cr}, \mathrm{Ni}, \mathrm{Cu}, \mathrm{Zn}, \mathrm{Mo}, \mathrm{Pb} \text {, } \\
\mathrm{Ag}, \mathrm{Cd}\end{array}$ & Espectrométrico & $\begin{array}{c}\text { ICP-OES, SpectroFlame } \\
\text { AAS, Perkin Elmer }\end{array}$ \\
\hline
\end{tabular}

Também foram coletadas amostras de água superficial do curso d'água receptor por meio do uso de dragas, a $50 \mathrm{~m}$ e $300 \mathrm{~m}$ do local de descarte nos pontos denominados P2 e $\mathbf{P} 4$, respectivamente, onde foram determinados os teores de sólidos totais, $\mathrm{pH}$, turbidez e a concentração dos metais presentes a cada hora a partir do despejo. Este estudo foi realizado com a finalidade de se verificar a dinâmica da dispersão do efluente da ETA, ao longo do curso d'água receptor.

\subsubsection{Caracterização da qualidade da água e do sedimento}

Todo programa de monitoramento ambiental deve identificar as condições existentes em um meio e sua variação num dado período de tempo, com o objetivo de se obter um cenário real da condição da qualidade dos recursos naturais. São várias as considerações envolvendo a seleção das posições dos pontos de coleta ao longo do rio. Por exemplo, a localização de pontos no qual a qualidade da água é de interesse para a potabilidade, pontos que recebem água de um efluente, pontos que recebem contribuição de um afluente, pontos que recebem grande quantidade de efluentes industriais ou domésticos, pontos que tenham representatividade da bacia ou da maioria dos bairros residenciais por onde atravessa, etc. $\dot{\mathrm{E}}$ essencial planejar o tempo de amostragem de modo a observar a variabilidade temporal, como períodos de estiagem, períodos chuvosos, atividades industriais ou agricolas aceleradas em determinadas épocas do ano. 
A partir dessas informações, foram realizados inicialmente um reconhecimento dos corpos d'água existentes na região do entorno da ETA, com o objetivo de se obter um cenário real da condição da qualidade dos recursos hídricos. Esta avaliação inicial permitiu definir uma representatividade na escolha dos pontos de amostragem e dos parâmetros selecionados, incluindo aqueles que indicassem o estado físico e a composição química da água, além dos complementares que seriam indicativos de poluição. Além da necessidade de se conhecer a composição fisico-química natural da água, deve-se também levar em consideração as substâncias incorporadas pelo lodo de ETA ao ambiente e as eventuais ações sinérgicas entre elas (Reis, 2004; Reis, 2005).

Foram coletadas amostras de água superficial e de sedimento, em pontos distintos do curso d'água receptor (Rio Sem Nome e Rio Ribeira de Iguape), a montante e a jusante do ponto de descarte do efluente. Os parâmetros avaliados neste estudo estão descritos na TAB.23. Essas variáveis para análise de águas superficiais foram selecionadas levando-se em conta a legislação Federal Resolução 357/2005; a Portaria 8648, parâmetros recomendados pelos órgãos ambientais (CETESB, 2005), o Índice de Preservação da Vida Aquática (IVA), o Índice de Parâmetros Mínimos para a preservação da vida aquática (IPMCA) e o Índice de Estado Trófico (IET).

TABELA 23 - Principais parâmetros para qualidade de águas (CETESB, 2005).

\begin{tabular}{ccc}
\hline Temperatura da Amostra & Oxigênio Dissolvido (OD) & Cobalto \\
Temperatura do Ar & Potássio & Boro \\
Turbidez & Cálcio & Alumínio \\
Alcalinidade & Magnésio & Vanádio \\
Dureza & Fósforo & Cromo \\
pH & Sódio & Manganês \\
Condutividade Específica & Chumbo & Niquel \\
Sólidos Sedimentáveis & Cádmio & Zinco \\
Sólidos Totais & Molibdênio & Prata \\
Sólidos Totais Fixos & Cobre & Estanho \\
Sólidos Totais Voláteis & Ferro & Bário \\
\hline
\end{tabular}


A caracterização das variáveis físicas $(\mathrm{pH})$ e químicas (elementos majoritários e elementos-traço) da água e do sedimento e suas respectivas frações foram realizadas em seis estações de coleta, conforme representação esquemática descrita na FIG.16.

Rio Sem Nome à montante do descarte

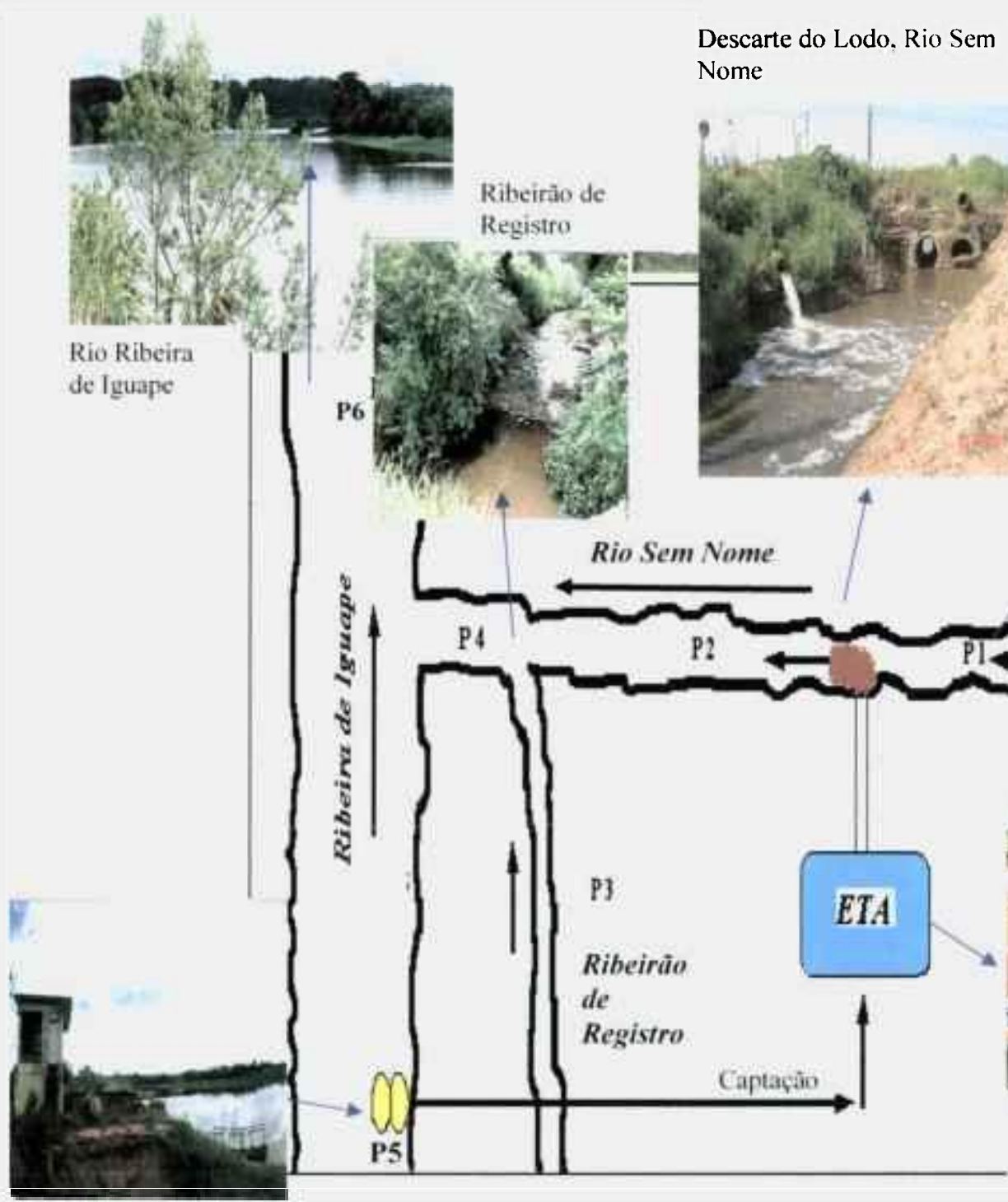

Captação da água superficial no Rio Ribeira de lguape

Estação de tratamento de água de Registro

FIGURA 16 - Localização dos pontos de coleta - Bacia Hidrográfica do rio Ribeira de Iguape, rio Sem Nome, Registro, SP. 
Quanto à periodicidade de amostragens, foram realizadas coletas a cada 30 dias, referente ao período de limpeza do decantador e com um intervalo de coleta de $24 \mathrm{~h}$ anterior e posterior ao descarte do lodo. As coletas foram feitas no período de dezembro de 2003 a agosto de 2004, totalizando 18 conjuntos de coleta. Com a finalidade de facilitar a identificação, as estações de amostragem foram relacionadas por convenções, conforme apresentado na TAB.24.

Como esquematizado na FIG.16, o lodo da ETA é despejado por gravidade em um pequeno córrego (rio Sem Nome), a $200 \mathrm{~m}$ da estação de tratamento de água. Este córrego percorre aproximadamente $3 \mathrm{~km}$ a montante do ponto de descarte, cruzando um bairro periférico de Registro, o qual é o responsável por grande parte do despejo de esgoto in natura. Foram definidos o ponto P1, a montante do despejo do lodo e o ponto $\mathrm{P} 2,50 \mathrm{~m}$ a jusante do ponto da descarga do lodo. $\mathrm{O}$ fato de haver um ribeirão afluente do córrego estudado (Ribeirão de Registro) antes do seu deságüe no rio Ribeira de Iguape, resultou em mais dois locais de coleta, correspondentes à montante (P3) e a jusante (P4) da contribuição deste outro ribeirão. Foram também definidos mais do is pontos no Rio Ribeira de Iguape, os pontos P5 e P6. O ponto P5 corresponde à captação de água para a ETA e o ponto P6 localiza-se à montante da foz do rio Sem Nome.

TABELA 24 - Caracterização e localização dos pontos de coleta (água superficial e sedimento de fundo).

\begin{tabular}{|c|c|c|c|}
\hline IDENTIFICAÇĀO & $\mathrm{RIO}$ & PONTO DE COLETA & LOCALIZAÇĀO (GPS) \\
\hline P1 & $\begin{array}{c}\text { Sem } \\
\text { Nome }\end{array}$ & Montante do Despejo da ETA & $\begin{array}{c}\text { 23J } 0210965-\text { UTM } \\
7288656 \\
\end{array}$ \\
\hline $\mathrm{P} 2$ & $\begin{array}{c}\text { Sem } \\
\text { Nome }\end{array}$ & Jusante do Despejo da ETA & $\begin{array}{c}\text { 23J } 0211321-\text { UTM } \\
7289062\end{array}$ \\
\hline P3 & $\begin{array}{l}\text { Ribeirão } \\
\text { de } \\
\text { Registro }\end{array}$ & $\begin{array}{c}\text { Montante - Contribuição do } \\
\text { Ribeirão de Registro ao Rio Sem } \\
\text { Nome }\end{array}$ & $\begin{array}{c}23 \mathrm{~J} 0211555-\mathrm{UTM} \\
7289604\end{array}$ \\
\hline P4 & $\begin{array}{l}\text { Sem } \\
\text { Nome }\end{array}$ & $\begin{array}{c}\text { Jusante - Contribuição do } \\
\text { Ribeirão de Registro ao Rio Sem } \\
\text { Nome }\end{array}$ & $\begin{array}{c}23 \mathrm{~J} 0212157-\mathrm{UTM} \\
7289417\end{array}$ \\
\hline P5 & $\begin{array}{l}\text { Ribeira } \\
\text { de } \\
\text { Iguape }\end{array}$ & $\begin{array}{l}\text { Montante - Contribuição do Rio } \\
\text { Sem Nome ao Ribeira de Iguape }\end{array}$ & $\begin{array}{c}23 \mathrm{~J} 0211444-\mathrm{UTM} \\
7290512\end{array}$ \\
\hline P6 & $\begin{array}{l}\text { Ribeira } \\
\text { de } \\
\text { Iguape }\end{array}$ & $\begin{array}{l}\text { Jusante - Contribuição do Rio } \\
\text { Sem Nome ao Ribeira de Iguape }\end{array}$ & $\begin{array}{c}\text { 23J } 0212148-\mathrm{UTM} \\
7289083\end{array}$ \\
\hline
\end{tabular}


As estações de amostragem foram demarcadas nos cursos d'água de acordo com localização da fonte poluidora em relação à montante desta, para se determinar as características naturais da área e à jusante, com o objetivo de avaliar o potencial de comprometimento dos despejos da ETA. Na TAB.25 estão relacionados os parâmetros e metodologias utilizadas para a avaliação das amostras. As coletas das amostras foram realizadas conforme recomendação do guia de coletas da CETESB (1991) e do Standard Methods (2004), considerando o tipo de frasco para cada parâmetro, volume necessário para análise, preservação de amostra e prazo para a realização da análise de cada parâmetro. $O$ procedimento utilizado para a preservação de amostras de água foi sob refrigeração à temperatura de $4^{\circ} \mathrm{C}$. Para a determinação de metais, as amostras foram filtradas e preservadas com a adição de solução de $\mathrm{HNO}_{3} 1: 1$ até $\mathrm{pH}<2$. As amostras de água bruta foram coletadas a aproximadamente $10 \mathrm{~cm}$ da superficie em frascos de polietileno. As amostras de sedimento foram coletadas em aproximadamente $30-50 \mathrm{~cm}$ de profundidade utilizando-se uma draga do tipo Ekman-Birge, com área igual a $22,5 \mathrm{~cm}^{2}$. Em alguns casos, devido à dificuldade de coleta, utilizou-se de um coletor de cereal ou uma enxada.

Alguns parâmetros como a temperatura do ar e das amostras de água e o teor de oxigênio dissolvido (OD) foram medidos em campo, nas próprias estações de amostragem. A sonda utilizada para medidas de OD e temperatura foi imersa a uma profundidade aproximada de $15 \mathrm{~cm}$ abaixo da superficie, enchendo-a completamente para evitar a entrada de bolhas de ar e deixado por alguns minutos até estabilização das leituras. Nos laboratórios de controle Sanitário da SABESP de Registro foram analisados outros parâmetros físicoquímicos como turbidez, pH, condutividade e alcalinidade. Em seguida, as amostras foram encaminhadas para os laboratórios do IPEN, onde foram analisados os demais parâmetros. As amostras de água bruta foram previamente filtradas e acidificadas e os metais ou elementos de interesse ( $\mathrm{Al}, \mathrm{Ba}, \mathrm{Ca}, \mathrm{Cd}, \mathrm{Cr}, \mathrm{Co}, \mathrm{Cu}, \mathrm{Fe}, \mathrm{Mg}, \mathrm{Mn}, \mathrm{Na}, \mathrm{Ni}, \mathrm{P}, \mathrm{Pb}, \mathrm{Zn}, \mathrm{K}, \mathrm{Mo}$, $\mathrm{B}, \mathrm{V}, \mathrm{Ag}$ e $\mathrm{Sn}$ ) foram determinados por espectrometria de emissão óptica com plasma de argônio (ICP-OES). A determinação dos metais nas amostras de sedimento foi realizada por meio de lixiviação dos metais presentes, utilizando-se do mesmo procedimento para as amostras de lodo recolhidas dos decantadores. Os resultados obtidos foram analisados utilizando-se o programa estatístico Statistica (Statsoft, 1998). 
TABELA 25 - Parâmetros para a avaliação das amostras de água superficial (APHA/AWWA/WEF 1998).

\begin{tabular}{|c|c|c|}
\hline PARÂMETRO & MÉTODO & EQUIPAMENTO \\
\hline $\mathrm{pH}$ & Eletrométrico & $\begin{array}{c}\text { pHmetro, Dm } 20, \\
\text { Digimed }\end{array}$ \\
\hline OD & Eletrométrico & $\begin{array}{c}\text { Oxímetro, } \mathrm{Dm} 2, \\
\text { Digimed }\end{array}$ \\
\hline Condutividade & Eletrométrico & $\begin{array}{c}\text { Condutivímetro, } \mathrm{Dm} 3 \text {, } \\
\text { Digimed }\end{array}$ \\
\hline Turbidez & Nefelométrico & $\begin{array}{c}\text { Turbidímetro, B 250, } \\
\text { Micronal }\end{array}$ \\
\hline Alcalinidade & Volumétrico & Bureta $(50 \mathrm{~mL})$ \\
\hline Sólidos sedimentáveis & $\begin{array}{c}\text { Cone Imhoff } \\
(1000 \mathrm{~mL})\end{array}$ & $\begin{array}{c}\text { Cone Graduado } \\
(1000 \mathrm{~mL})\end{array}$ \\
\hline Dureza & $\begin{array}{l}\text { Volumétrico } \\
\text { (EDTA) }\end{array}$ & Bureta $(50 \mathrm{~mL})$ \\
\hline $\begin{array}{c}\text { Metais e elementos - traço } \\
\mathrm{Na}, \mathrm{Mg}, \mathrm{Ca}, \mathrm{P}, \mathrm{K}, \mathrm{Fe}, \mathrm{Al}, \mathrm{Mn}, \\
\mathrm{Ba}, \mathrm{Co}, \mathrm{B}, \mathrm{V}, \mathrm{Cr}, \mathrm{Ni}, \mathrm{Cu}, \mathrm{Zn}, \\
\mathrm{Mo}, \mathrm{Pb}, \mathrm{Ag}, \mathrm{Cd}\end{array}$ & Espectrométrico & $\begin{array}{l}\text { ICP-OES, Spectroflame } \\
\text { AAS, Perkin Elmer }\end{array}$ \\
\hline $\begin{array}{c}\text { Série de sólidos } \\
\text { SólidosTotais (ST), } \\
\text { Sólidos Totais Fixos (STF) } \\
\text { Sólidos Totais Voláteis (STV) }\end{array}$ & $\begin{array}{l}\text { Gravimétrico } \\
\text { Gravimétrico } \\
\text { Gravimétrico }\end{array}$ & $\begin{array}{c}\text { Estufa } \\
\text { Mufla } \\
\text { Estufa/Mufla }\end{array}$ \\
\hline
\end{tabular}

Uma análise complementar do sedimento foi realizada utilizando a avaliação dos organismos bentônicos. $\mathrm{O}$ procedimento de coleta e as análises foram realizados de acordo com Brandimarte (1998), onde o sedimento coletado para a análise da macrofauna bentônica foi devidamente lavado (peneira $250 \mu \mathrm{m}$ ) em seguida flotado em solução de cloreto de sódio. O sobrenadante e restos de substratos foram preservados em solução de formol $4 \%$ e os organismos foram identificados em nível de familia.

\subsubsection{Cálculo da vazão dos cursos d'água receptores do lodo da ETA}

Foram medidas as vazões dos rios relacionados ao estudo, de forma a se avaliar o comprometimento da qualidade dos rios à jusante da ETA de Registro em conseqüência do recebimento da carga poluidora, além da contribuição do curso d'água diretamente receptor do descarte da ETA para as águas do Rio Ribeira de Iguape. 
Em situações onde se constate um impacto ambiental e com base nas medidas de descarga líquida realizada nos cursos d'água, pode-se também determinar a relação da cota em função da descarga, determinando-se a descarga líquida correspondente para cada cota ou nível d'água no ponto em estudo. A importância da medida de vazão durante uma programação de monitoramento é pelo fato de se poder com isso determinar o impacto da carga poluente no corpo d'água receptor.

Para a determinação da vazão média do rio Sem Nome foi escolhido um trecho do rio com seção uniforme. Em função de atividades de limpeza mantida pela prefeitura municipal de Registro, o rio apresenta um percurso retificado próximo à ETA (FIG.17), facilitando as atividades de medidas de vazão. As medidas foram executadas por dois meses seguidos em um período próximo à estiagem, de forma que a vazão medida não fosse influenciada por precipitações variáveis. Foram realizadas medições nos meses de abril e maio de 2004.

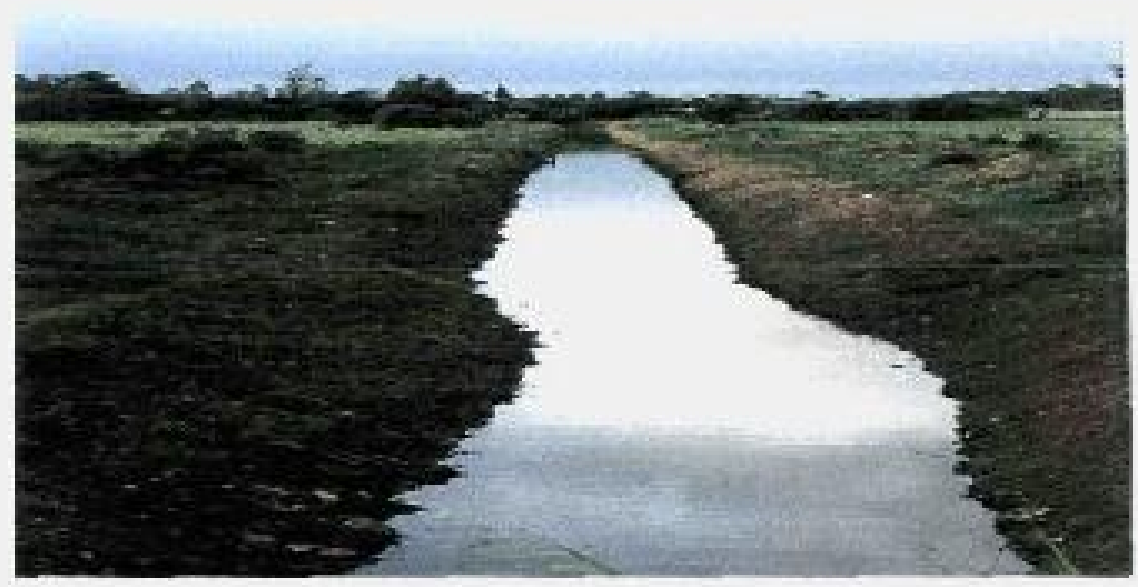

FIGURA 17 - Seção do rio Sem Nome próximo à ETA de Registro.

A largura do rio foi medida em metros, esticando-se uma corda entre as duas margens do rio. A largura média encontrada foi de $0,4 \mathrm{~m}$. A profundidade do rio foi calculada medindo-se em cinco locais diferentes, calculando-se a profundidade média. $\mathrm{O}$ valor médio encontrado para os dois meses foi de $0.55 \mathrm{~m}$. A seguir, foi calculada a área (A) da seção do rio em metros quadrados, conforme a equação (7): 


$$
\mathrm{A}=0,55 \mathrm{~m} \times 0,4 \mathrm{~m}=0,22 \mathrm{~m}^{2}
$$

A velocidade do rio foi medida utilizando-se um frasco plástico preenchido com água pela metade e que flutuasse livremente. Mediu-se o tempo necessário (em segundos) para o frasco percorrer certa distância definida entre dois pontos no rio. $O$ tempo para o frasco percorrer uma distância de $4 \mathrm{~m}$ foi, em média, de 16 segundos. A velocidade média obtida foi de 0,25 metros por segundo. A vazão do rio (Q) foi calculada aplicando-se a equação (8) (Sperling, 1996):

$$
Q=\mathbf{v} \cdot \mathbf{A}
$$

A equação (8) apresentou um resultado de $Q=0,25 \mathrm{~m}^{2} \times 0,22 \mathrm{~m} \cdot \mathrm{s}^{-1}=0,055 \mathrm{~m}^{3} \cdot \mathrm{s}^{-1}$. Os valores para as vazões médias (mensal e anual) do rio Ribeira de Iguape podem ser observados na TAB.26. O rio apresentou para o período 1960-2000, uma vazão média de $422 \mathrm{~m}^{3} \cdot \mathrm{s}^{-1}$. Na comparação entre as médias mensais é possivel distinguir-se o período de chuvas, especialmente entre os meses de Janeiro a Março, com uma média de vazão de 635 $\mathrm{m}^{3} \cdot \mathrm{s}^{-1}$, contra o período de estiagem (Junho-Agosto), com uma vazão média de aproximadamente $360 \mathrm{~m}^{3} \cdot \mathrm{s}^{-1}$.

Em razão das vazões observadas para ambos os períodos no rio Ribeira de Iguape, espera-se também características distintas entre rios de pequeno porte existentes na bacia hidrográfica. A consideração da qualidade ambiental na área de estudo em função das flutuações climáticas permite uma avaliação mais realista em relação à presença de contaminantes da ETA no ecossistema. 
TABELA 26 - Vazões do rio Ribeira de Iguape no município de Registro (1960-2000).

\begin{tabular}{|c|c|c|c|c|c|c|c|c|c|c|c|c|c|}
\hline \multirow[b]{2}{*}{ Ano } & \multicolumn{13}{|c|}{ Vazoes Médias Mensais $\left(\mathrm{m}^{3} \cdot \mathrm{s}^{-\mathrm{t}}\right)$} \\
\hline & Jan. & Fev. & Mar. & Abr. & Maio & Jun. & Jul. & Ago. & Set. & Out. & Nov. & Dez. & $\begin{array}{l}\text { Média } \\
\text { Anual }\end{array}$ \\
\hline 1960 & 407 & 538 & 518 & 369 & 396 & 310 & 252 & 306 & 264 & 314 & 422 & 409 & 427 \\
\hline 1961 & 485 & 736 & 953 & 718 & 510 & 433 & 320 & 257 & 317 & 304 & 384 & 421 & 389 \\
\hline 1962 & 445 & 470 & 890 & 424 & 313 & 268 & 248 & 237 & 324 & 582 & 461 & 430 & 395 \\
\hline 1963 & 1027 & 714 & 512 & 386 & 307 & 276 & 232 & 212 & 212 & 375 & 472 & 406 & 300 \\
\hline 1964 & 260 & 415 & 298 & 306 & 273 & 421 & 316 & .273 & 276 & 317 & 304 & 443 & 483 \\
\hline 1965 & 536 & 703 & 475 & 371 & 937 & 410 & 502 & 338 & 328 & 457 & 375 & 742 & 511 \\
\hline 1966 & 691 & 1071 & 671 & 753 & 524 & 368 & 396 & 316 & 381 & 524 & 640 & 553 & 462 \\
\hline 1967 & 547 & 946 & 1049 & 522 & 371 & 457 & 393 & 288 & 290 & 291 & 412 & 495 & 333 \\
\hline 1968 & 826 & 451 & 499 & 452 & 320 & 284 & 250 & 234 & 221 & 302 & 238 & 373 & 352 \\
\hline 1969 & 285 & 376 & 371 & 384 & 245 & 357 & 329 & 223 & 209 & 403 & 915 & 510 & 463 \\
\hline 1970 & 631 & 660 & 690 & 467 & 473 & 539 & 488 & 349 & 454 & 417 & 371 & 480 & 395 \\
\hline 1971 & 887 & 444 & 642 & 412 & 438 & 449 & 400 & 304 & 313 & 315 & 246 & 304 & 463 \\
\hline 1972 & 542 & 888 & 609 & 525 & 301 & 258 & 279 & 350 & 437 & 961 & 482 & 445 & 496 \\
\hline 1973 & 605 & 839 & 581 & 785 & 479 & 418 & 473 & 466 & 696 & 500 & 484 & 406 & 375 \\
\hline 1974 & 674 & 460 & 724 & 455 & 321 & 386 & 292 & 247 & 302 & 307 & 297 & 490 & 422 \\
\hline 1975 & 537 & 731 & 752 & 425 & 335 & 280 & 317 & 305 & 260 & 438 & 453 & 656 & 542 \\
\hline 1976 & 768 & 966 & 903 & 617 & 519 & 583 & 547 & 467 & 477 & 456 & -412 & 405 & 369 \\
\hline 1977 & 607 & 670 & 428 & 584 & 392 & 334 & 282 & 253 & 283 & 385 & 330 & 463 & 260 \\
\hline 1978 & 376 & 334 & 409 & 263 & 236 & 230 & 251 & 215 & 307 & 171 & 331 & 262 & 327 \\
\hline 1979 & 311 & 304 & 382 & 296 & 376 & 229 & 237 & 242 & 408 & 413 & 523 & 498 & 388 \\
\hline 1980 & 547 & 713 & 542 & 420 & 283 & 296 & 394 & 320 & 369 & 370 & 300 & 518 & 360 \\
\hline 1981 & 1025 & 538 & $44 !$ & 384 & 316 & 283 & 282 & 234 & 204 & 292. & 328 & 384 & 417 \\
\hline 1982 & 284 & 433 & 458 & 401 & 294 & 477 & 561 & 329 & 279 & 459 & 675 & 759 & 827 \\
\hline 1983 & 869 & 898 & 1014 & 749 & 970 & 1754 & 1045 & 571 & 943 & 720 & 559 & 585 & 382 \\
\hline 1984 & 542 & 516 & 380 & 439 & 452 & 340 & 305 & 375 & 398 & 307 & 419 & 550 & 269 \\
\hline 1985 & 475 & 477 & 485 & 417 & 315 & 275 & 219 & 187 & 216 & 171 & 234 & 166 & 297. \\
\hline 1986 & 221 & 499 & 512 & 286 & 281 & 207 & 223 & 245 & 242 & 252 & 280 & 602 & 390 \\
\hline 1987 & 500 & 588 & 321 & 304 & 675 & 712 & 359 & 282 & 337 & 353 & 282 & 268 & 395 \\
\hline 1988 & 428 & 594 & 603 & 360 & 687 & 559 & 340. & 264 & 318 & 332 & 298 & 311 & 399 \\
\hline 1989 & 857 & - & $=$ & 446 & 425 & 331 & 357 & 446 & 403 & 326 & 301 & 348 & 389 \\
\hline 1990 & - & 512 & 541 & 431 & 363 & 300 & 458 & 395 & 486 & 424 & 473 & 370 & 398 \\
\hline 1991 & 394 & 663 & 795 & 537 & 430 & 405 & 333 & 286 & 247 & 427 & 310 & 306 & 340 \\
\hline 1992 & 248 & 336 & 536 & 383 & 434 & 376 & 320. & 306 & 326 & 388 & 401 & 413 & 430 \\
\hline 1993 & 477 & 776 & 620 & 447 & 363 & 474 & 361 & 287 & 485 & 606 & 344 & 372 & 401 \\
\hline 1994 & 469 & 847 & 777 & 541 & 424 & 394 & 343 & 265 & 246 & 276 & 408 & 364 & 543 \\
\hline 1995 & 1130 & 1103 & 800 & 573 & 434 & 364 & 443 & 352 & 395 & 561 & 526 & 403 & 585 \\
\hline 1996 & 857 & 1156 & 1144 & 837 & 525 & 471 & 412 & 366 & 527 & 551 & 492 & 518 & 557 \\
\hline 1997 & 1105 & 979 & 595 & 430 & 370 & 395 & 440 & 369 & 392 & 610 & 780 & 644 & 625 \\
\hline 1998 & 849 & 676 & 1190 & 860 & 584 & 477 & 472 & 469 & 719 & 1056 & 524. & 480 & 458 \\
\hline 1999 & 915 & 1001 & 766 & 560 & 402 & 360 & 525 & 291 & 331 & 313 & 243 & 350 & 344 \\
\hline 2000 & 443 & 663 & 537 & 396 & 224 & 212 & 189 & 237 & 506 & 287 & 362 & 462 & 338 \\
\hline Média Mensal & 602 & 667 & 635 & 481 & 422 & 409 & 370 & 311 & 369 & 422 & 417 & -448 & 422 \\
\hline Desvio & 248 & 229 & 224 & 152 & 163 & 241 & 145 & 83 & 150 & 180 & 146 & 124 & 105 \\
\hline
\end{tabular}

fonte: http:www.sigrh.sp.gov.br/cgi-bin/bdhm.exe/procuraflu (adaptado). 


\section{RESULTADOS E DISCUSSÃO}

\subsection{Caracterização da ETA de Registro (SABESP/SP)}

Os municípios do Vale do Ribeira possuem 43 sistemas produtores de água distribuidos em áreas de captação de água superficial, manancial de serra e poços. Todos os sistemas produtores são operados e administrados pela SABESP por meio da Unidade de Negócio do Vale do Ribeira. Destes, 18 são sistemas de tratamento tradicional (prédesinfecção, coagulação, floculação, decantação, filtração, correção de pH, desinfecção e fluoretação). O município de Registro possui três sistemas produtores sendo um tipo ETA e dois do tipo poço, como mostrado na TAB.27.

TABELA 27 - Caracterização e localização dos sistemas produtores do município de Registro, no Vale do Ribeira.

\begin{tabular}{|c|c|c|c|c|c|c|}
\hline MUNICIPIO & $\begin{array}{c}\text { SISTEMA } \\
\text { PRODUTOR }\end{array}$ & $\begin{array}{l}\text { CódIGo } \\
\text { SABESP }\end{array}$ & $\begin{array}{l}\text { Tipo de } \\
\text { Sistema }\end{array}$ & CAPTAÇĀO & $\begin{array}{l}\text { CLASSIFICAÇĀO DO } \\
\text { CORPO DE ÁGUA }\end{array}$ & $\begin{array}{l}\text { LOCALIZAÇÃO } \\
\text { GPS }\end{array}$ \\
\hline \multirow{3}{*}{ Registro } & Registro & LR001 & ETA & $\begin{array}{c}\text { Rio Ribeira do } \\
\text { Iguape }\end{array}$ & Classe 2 & $\begin{array}{l}\text { S } 24^{\circ} 28^{\prime} 25^{\prime \prime} \\
\text { O } 47^{\circ} 50^{\prime} 37^{\prime \prime}\end{array}$ \\
\hline & Serrote & LR003 & Poço & $\begin{array}{c}\text { Poço } \\
\text { profundo }\end{array}$ & - & $\begin{array}{l}\text { S } 24^{\circ} 24^{\prime} 25^{\prime \prime} \\
\text { O } 47^{\circ} 44^{\prime} 52^{\prime \prime} \\
\end{array}$ \\
\hline & Carapiranga & LR 004 & Poço & $\begin{array}{c}\text { Poço } \\
\text { Profundo }\end{array}$ & - & $\begin{array}{l}\text { S } 24^{\circ} 31^{\prime} 42^{\prime \prime} \\
\text { O } 47^{\circ} 53^{\prime} 11^{\prime \prime}\end{array}$ \\
\hline
\end{tabular}

A ETA de Registro (FIG.18) destaca-se por ser o maior sistema da região e também por ser a sede operacional dos demais sistemas. Projetada para operar com uma capacidade nominal de $212 \mathrm{~L} . \mathrm{s}^{-1}$, atualmente possui uma capacidade variável de 155 a $180 \mathrm{~L} . \mathrm{s}^{-1}$, por um período médio de 16 horas por dia. A capacidade dos reservatórios de água tratada é de $6.000 \mathrm{~m}^{3}$, atendendo um total de 12.000 ligações. A estação é composta por dois módulos de tratamento, contendo dois decantadores, seis floculadores hidráulicos e quatro filtros com quatro câmaras cada. 


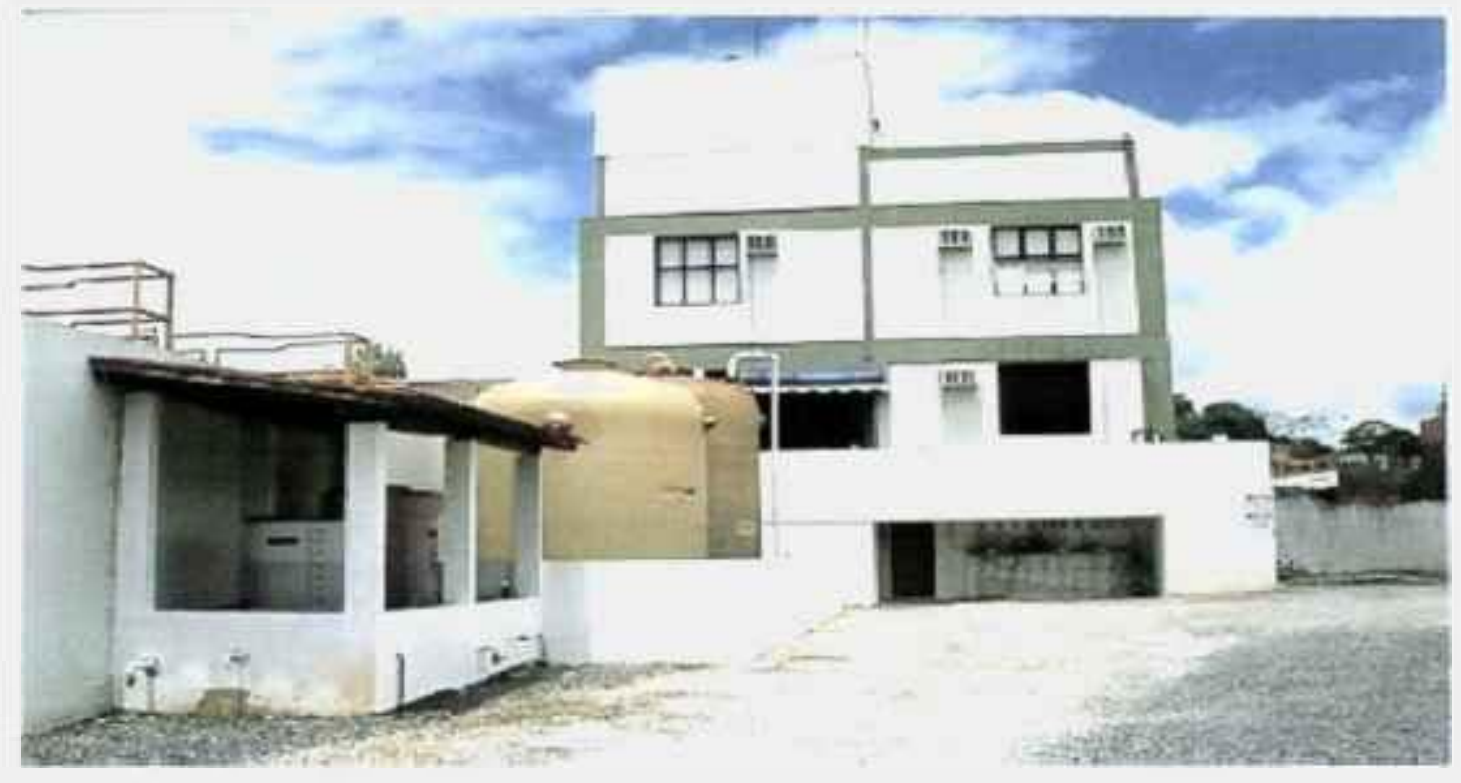

FIGURA 18 - Representação fotográfica da ETA de Registro (SABESP).

A água que alimenta a estação provém do rio Ribeira de Iguape e é captada com uma vazão média de $465,94 \mathrm{~m}^{3} \cdot \mathrm{s}^{-1}$. A água bruta flui pela estação elevatória - EEAB (estação elevatória de água bruta) representada na FIG.19, a qual é composta por duas bombas submersas de $100 \mathrm{CV}$ (FIG.20) e uma adutora, com um diâmetro de $400 \mathrm{~mm}$ e $1.200 \mathrm{~m}$ de comprimento.

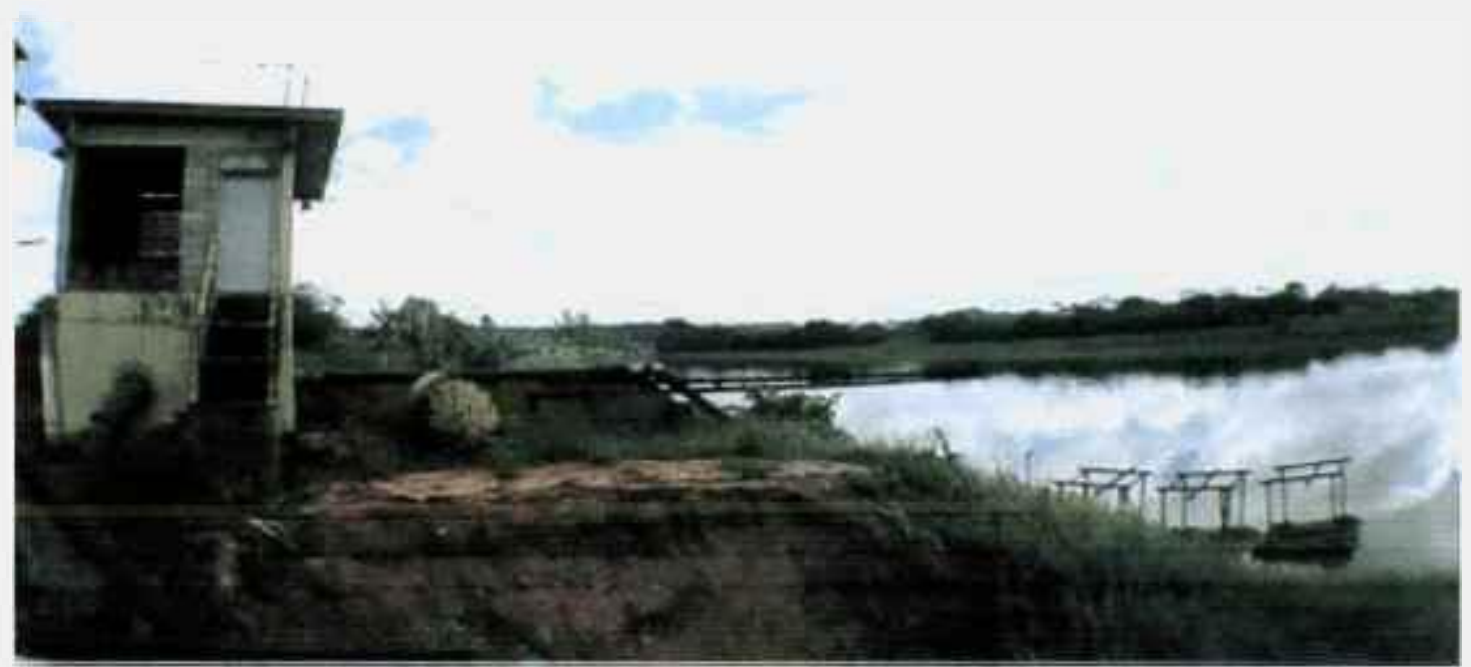

FIGURA 19 - Estação de captação de água no rio do Ribeira de Iguape (SABESP). 


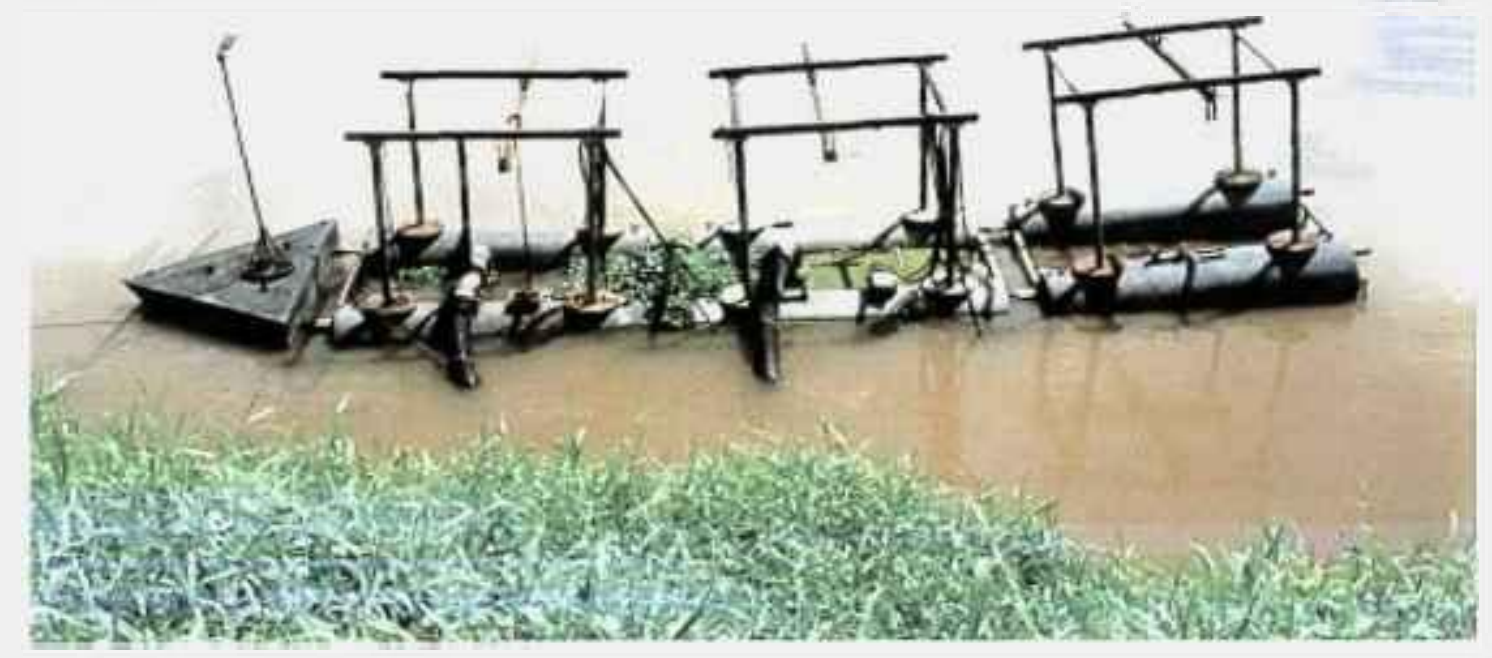

FIGURA 20 - Captação de água no rio do Ribeira de Iguape (SABESP).

A ETA de Registro é totalmente automatizada pelo processo AQUALOG®. Um sistema criado e desenvolvido pela SABESP - Unidade de Negócio Vale do Ribeira e Litoral Sul, para automação na área de saneamento. O sistema possibilita a operação de todo o tratamento de água com máxima eficiência dos sistemas produtores de água e de tratamento de efluentes, proporcionando menores custos operacionais, maior confiabilidade e segurança. O sistema permite a tomada de decisões on-line, ajustando-se de acordo com as necessidades, para a obtenção de melhor desempenho e excelência em qualidade.

O sistema também controla as dosagens de produtos químicos, acionando automaticamente válvulas e monitorando reservatórios além de disponibilizar tabelas e gráficos de tendências, que proporcionam o aperfeiçoamento das rotinas de controle. Mesmo havendo alterações bruscas na qualidade da água bruta, o sistema realiza o controle automático de todos os parâmetros de processo e ajusta automaticamente a estação de tratamento.

A chegada de água bruta na ETA ocorre por meio de uma caixa equilibradora de fluxo (Calha Parshall), com a finalidade de diminuir a velocidade da água e manter uma vazão constante (FIG.21). A água bruta na adutora de água bruta - AAB passa por um sistema eletrônico de fluxo que é responsável pela manutenção do sinal que mantém a EEAB e pela medição da vazão afluente. 


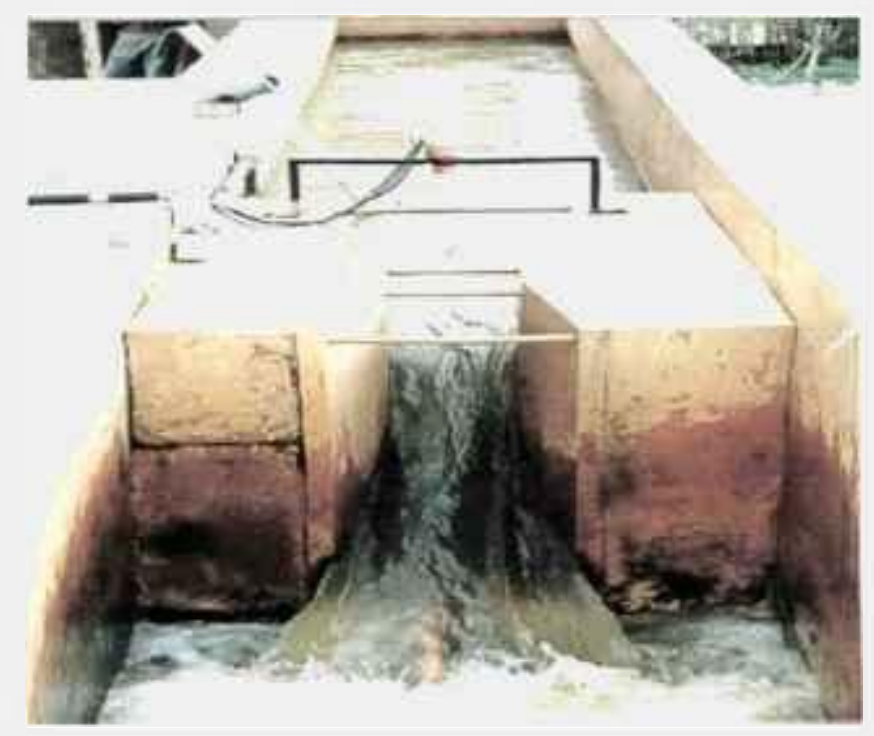

FIGURA 21 - Entrada de água na ETA de Registro, proveniente da estação de captação.

\subsection{Processos de tratamento}

\subsubsection{Desinfecção}

Pré-cloração: Na etapa de pré-cloração, o cloro é aplicado no início do processo de tratamento para se obter um teor de residual na faixa de 0.1 a $0,2 \mathrm{mg} . \mathrm{L}^{-1}$ nos efluentes dos filtros. A etapa de pré-cloração é utilizada para a eliminação preventiva de microrganismos patogênicos capazes de causar doenças. Também contribui para a redução da cor no processo de coagulação, reduzindo gosto, odor da água e o potencial para criação de condições sépticas do lodo depositado, controlando o crescimento de matérias orgânicas no meio filtrante e nas paredes dos decantadores.

A adição de cloro auxilia também na oxidação do ferro presente, conforme reação abaixo, propiciando a formação de partículas coloidais que possam ser removidas pela decantação (sedimentação) e filtração.

$$
6 \mathrm{FeSO}_{4} .7 \mathrm{H}_{2} \mathrm{O}+3 \mathrm{Cl}_{2}---->2 \mathrm{Fe}_{2}\left(\mathrm{SO}_{4}\right)_{3}+2 \mathrm{FeCl}_{3}+7 \mathrm{H}_{2} \mathrm{O}
$$

$\mathrm{Na}$ estação é utilizado um cilindro de cloro líquido com capacidade de $900 \mathrm{~kg}$ e com $99.99 \%$ de pureza $\left(\mathrm{em} \mathrm{Cl}_{2}\right)$. 
Pós-Cloração: O cloro residual livre na água tratada é mantido em torno de $1,5 \mathrm{mg} . \mathrm{L}^{-1}$. O consumo diário de cloro é de aproximadamente 30 a $40 \mathrm{~kg}$ e sua aplicação no final do processo de tratamento, denominado de pós-cloração, tem a finalidade de proteger a água contra possíveis contaminações desde o sistema de distribuição até o consumo. O gás cloro é misturado à água tratada e, em reação com a água, pode formar compostos como o ácido hipocloroso ( $\mathrm{HOCl})$ e hipoclorito $(\mathrm{OCl})$.

\subsubsection{Coagulação}

$O$ coagulante utilizado é o sulfato de alumínio, $\mathrm{Al}_{2}\left(\mathrm{SO}_{4}\right)_{3} 18 \mathrm{H}_{2} \mathrm{O}$, que é adicionado no canal de água bruta na estação, na saída da calha Parshall, onde ocorre a mistura rápida. A dosagem do coagulante é controlada automaticamente por um analisador de coagulante (FIG.22). A reação entre o coagulante e os hidróxidos existentes na água bruta é rápida, formando hidróxidos de alumínio em poucos segundos.

$\mathrm{Na}$ água bruta, além de partículas sedimentáveis, existem impurezas em suspensão, no estado coloidal ou suspensão (bactérias, protozoários e plâncton). A coagulação se refere às trocas fisico-químicas que ocorrem entre o coagulante e os hidróxidos presentes para formar um precipitado. Como consequuência, os colóides da água bruta são desestabilizados, reduzindo ou neutralizando sua carga elétrica. Assim, as partículas coloidais estarão prontas para serem agrupadas pela força mecânica dos floculadores.

O sulfato de alumínio líquido é estocado em um tanque com capacidade de $20 \mathrm{~m}^{3}$. Deste tanque, o produto químico flui para os dosadores que se encontram instalados imediatamente junto aos misturadores rápidos. A adição de sulfato de alumínio varia em função da vazão medida na entrada da estação e da qualidade de água a ser tratada, conforme ação do analisador de cargas e mantendo-se a dosagem ideal para qualquer alteração de vazão. O consumo de sulfato de alumínio líquido a $58 \%$ é de $500 \mathrm{~kg} \cdot \mathrm{dia}^{-1}$. 


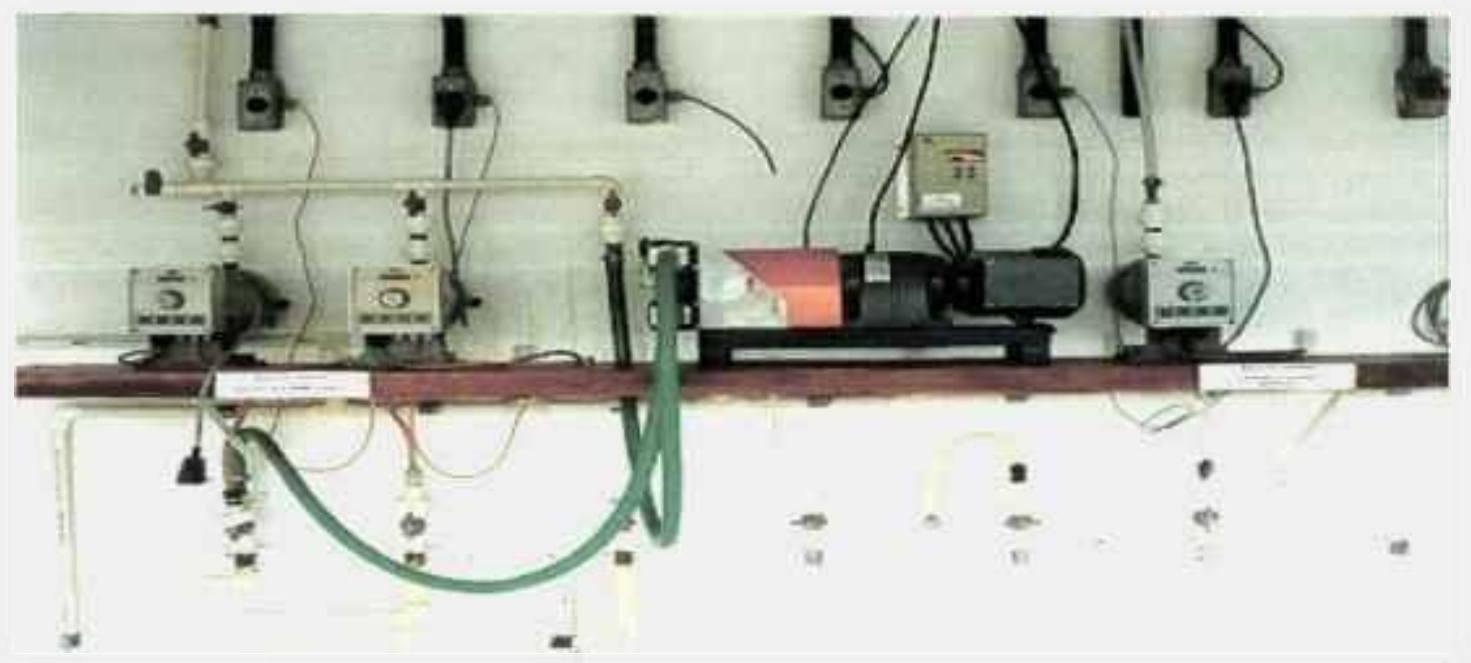

FIGURA 22 - Monitores e dosadores automáticos para a adição de floculantes e coagulantes pela ETA de Registro.

\subsubsection{Floculação}

Após a coagulação, as partículas coloidais estão prontas para serem agrupadas pela força mecânica dos floculadores. Na TAB.28 são apresentadas as principais características dos floculadores da ETA de Registro. Os floculadores estão equipados com unidade de acionamento para transmitir energia à água, mantendo-a em movimento de turbulência relativamente suave, conforme mostrado na FIG.23. À medida que a água passa pelos floculadores, as partículas de impurezas colidem com as partículas sólidas suspensas e, aderindo umas às outras, aumentam de tamanho e densidade.

TABELA 28 - Características dos floculadores da ETA de Registro.

\section{FLOCULADOR}

Detenção média

Capacidade de cada floculador

Área de cada floculador

$$
\text { Volume total }
$$

Altura média de água

Quantidade de Floculadores
$41 \mathrm{~min}$.

$74,82 \mathrm{~m}^{3}$

$16,85 \mathrm{~m}^{2}$

$448,92 \mathrm{~m}^{3}$

$4.44 \mathrm{~m}$

6 unidades 


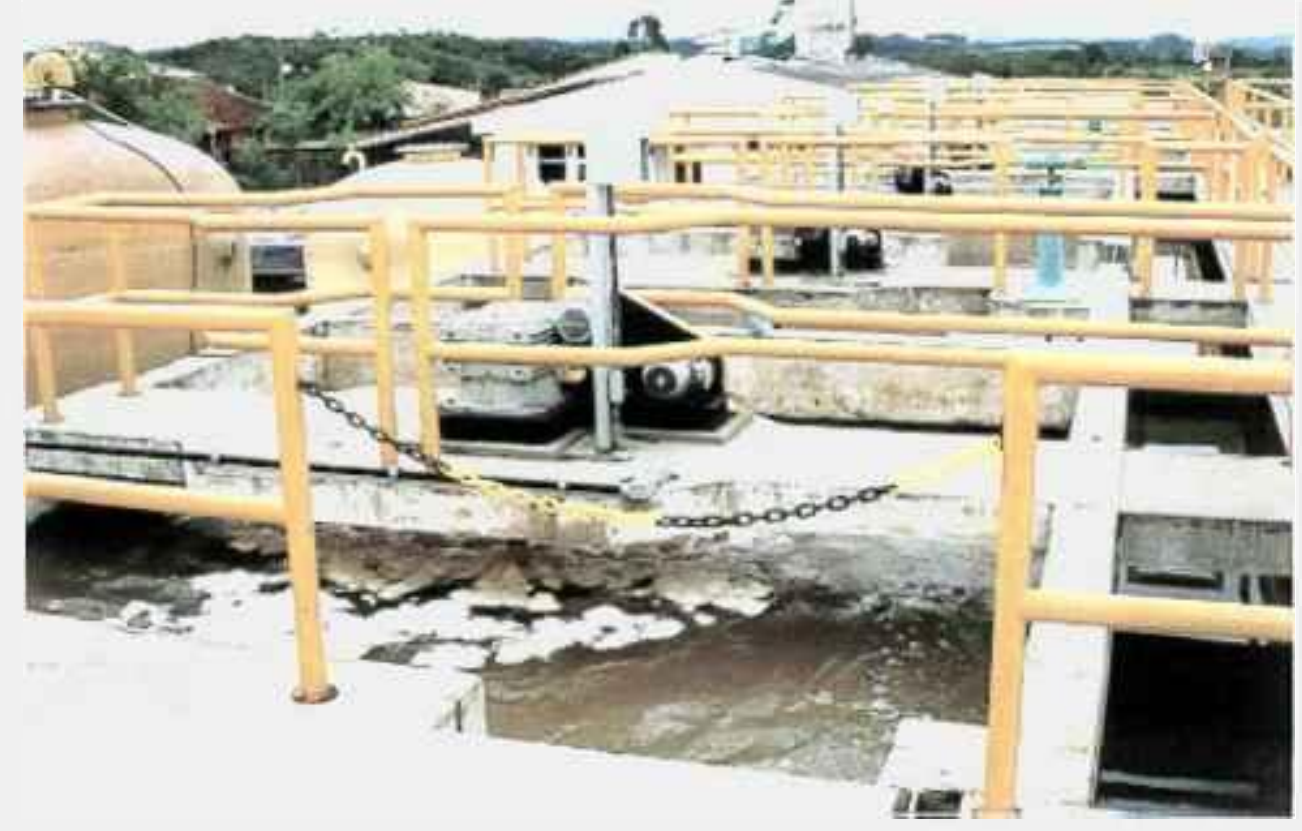

FIGURA 23 - Tanques de floculação e coagulação, ETA de Registro.

Os floculadores são compostos por seis câmaras interligadas que possuem um agitador mecânico tipo pá, onde a água entra pela parte superior e, após um tempo de contato, segue para a segunda câmara entrando pela parte inferior desta. Deste modo, a água passa por diferentes gradientes de agitação, que decrescem no sentido do fluxo para os decantadores. O volume de cada câmara é de $74,82 \mathrm{~m}^{3}$, proporcionando um tempo de detenção de 41 minutos, condicionando a água para o processo de decantação.

\subsubsection{Decantação}

Na TAB.29 são apresentadas as principais características dos decantadores da ETA de Registro. A separação entre o decantador e floculador é feita por uma cortina de madeira ou difusor, evitando assim que se propague para o decantador, a turbulência criada no floculador. Obtém-se com isto um movimento laminar com baixa velocidade, permitindo que os flocos se acomodem antes que a água seja coletada pelas canaletas, localizadas na parte superior dos decantadores. Os flocos se depositam nos decantadores, direcionados ao fundo dos tanques pela presença de um anteparo inclinado (FIG.24 e 25). 
TABELA 29 - Principais características dos decantadores da ETA de Registro.

\section{DECANTADOR}

Detenção média

Velocidade horizontal média

Taxa média de aplicação

Tanques

Capacidade de cada tanque

Volume total

Altura média de água

Área de cada tanque

Vol. de lodo retirado, com $1 \%$ em sólidos.
$202 \min$

$6 \mathrm{~cm} \cdot \mathrm{min}^{-1}$

$44 \mathrm{~m}^{3} \cdot \mathrm{m}^{-2} \mathrm{dia}$

2 unidades

$771,15 \mathrm{~m}^{3}$

$1.542,30 \mathrm{~m}^{3}$

$4,36 \mathrm{~m}$

$176,87 \mathrm{~m}^{2}$

$12 \mathrm{~m}^{3} \cdot \mathrm{dia}^{-1}$

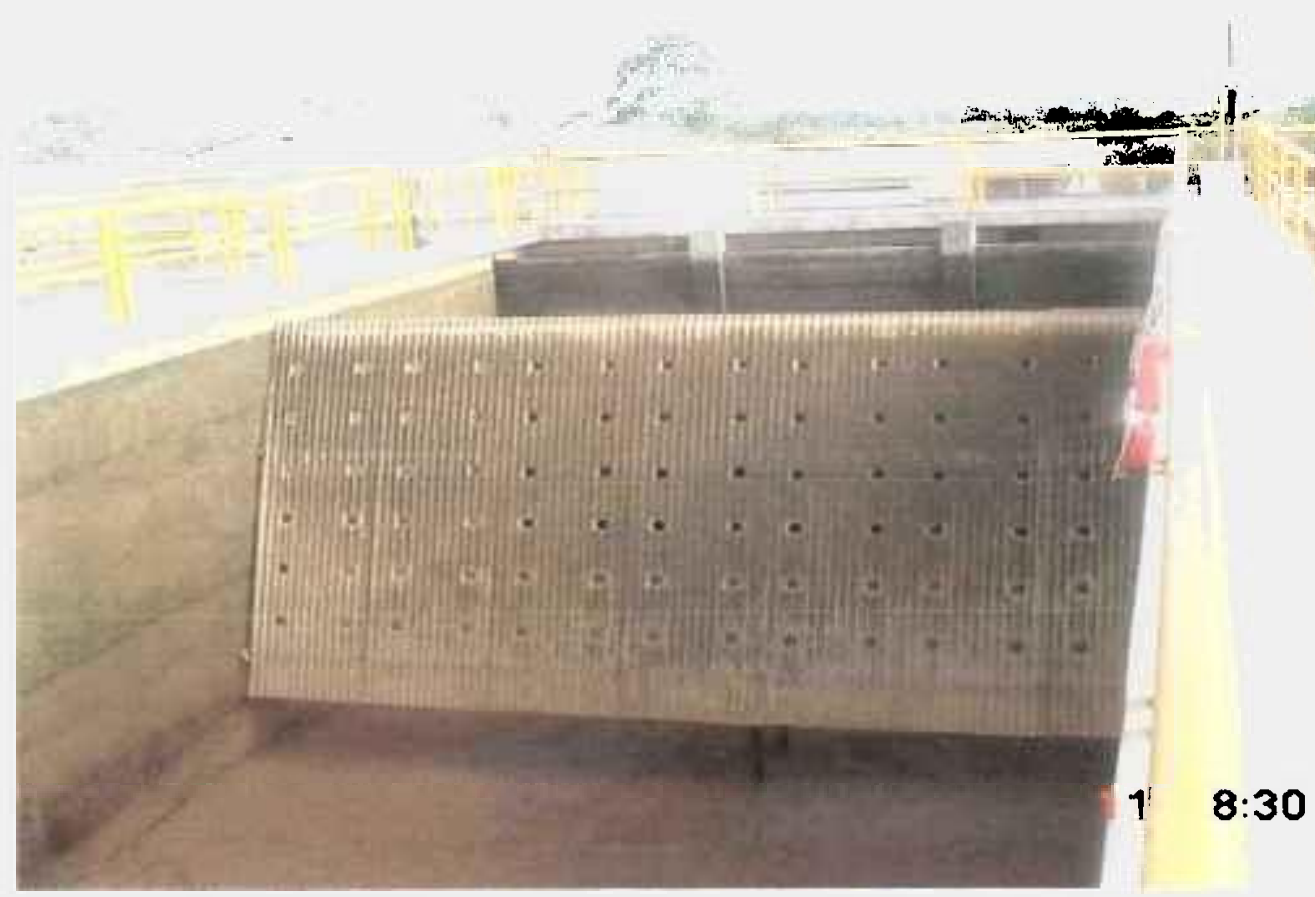

FIGURA 24 - Decantador da ETA de Registro, com o lodo depositado.

Como pode ser observado nas FIG. 24 e 25 , após o processo de decantação de grande parte das partículas insolúveis, a água é conduzida por canaletas para a saída em direção ao filtro (FIG.26). 


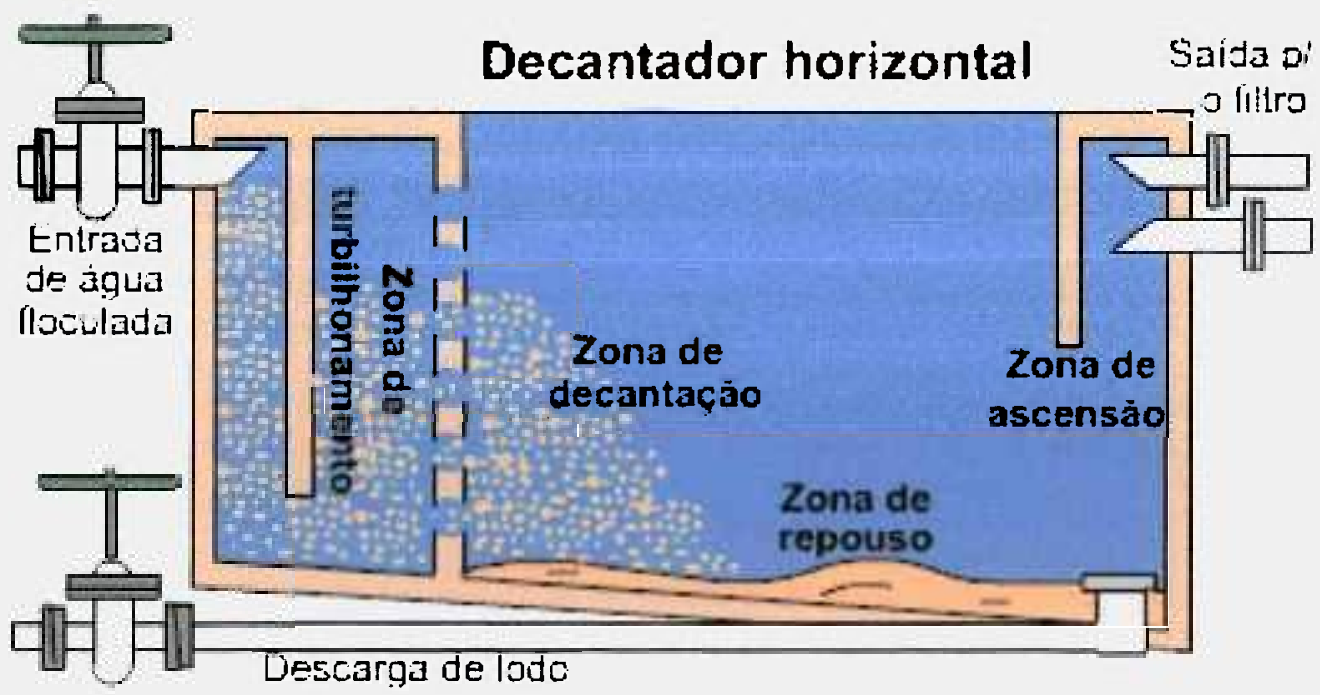

Fonte: http://www.ocaminhodaagua.hpg.ig.com.br/dec.html

FIGURA 25 - Representação esquemática de um decantador de uma ETA.

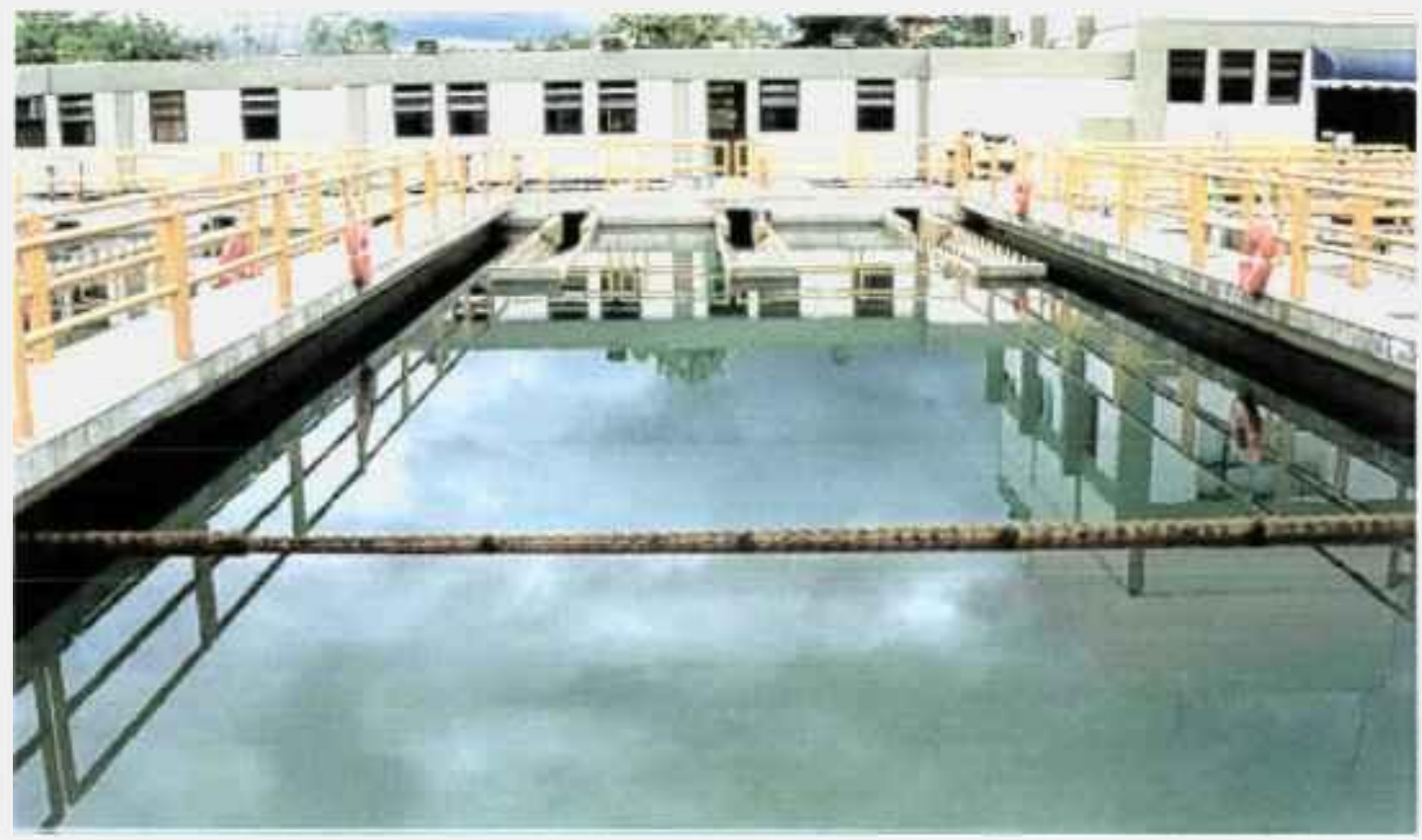

FIGURA 26 - Tanque de decantação com saída de água para a fase de filtragem.

A camada de lodo depositada ao fundo dos tanques de decantação é removida dentro em um prazo de 30 a 40 dias, pela abertura da válvula de descarga (FIG.27). 


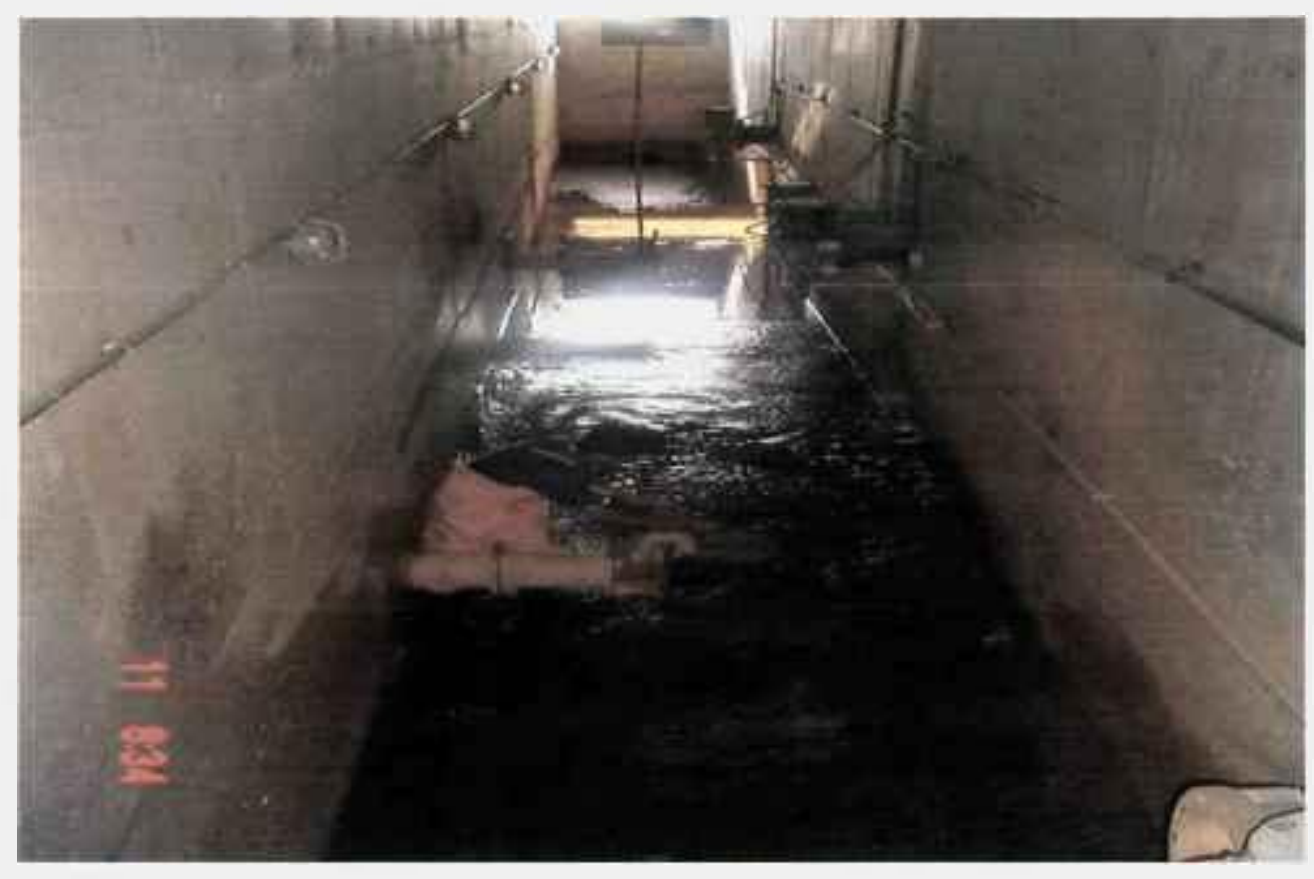

FIGURA 27 - Liberação do lodo retido no decantador.

\subsubsection{Filtração}

Na TAB.30 são apresentadas as principais características da unidade de filtração da ETA de Registro. A unidade é composta por quatro filtros rápidos de fluxo descendente, operados com taxa declinante e meio filtrante de antracito e areia. Na TAB.3I são descritas as principais características do meio filtrante.

TABELA 30 - Características dos filtros da ETA de Registro.

\section{FILTRO}

Rápido por gravidade de areia e carvão 4 unidades

antracito

Taxa média de filtração

$338 \mathrm{~m}^{3} \cdot \mathrm{m}^{-2}$ por dia

Vazão de filtração por filtro

$0,97 \mathrm{~m}^{3} \cdot \mathrm{s}^{-1}$

Carreira de filtração

$32 \mathrm{~h}$

Área superficial do meio filtrante por filtro

$16,57 \mathrm{~m}^{2}$

Total de todos os filtros

$66,28 \mathrm{~m}^{2}$

Quantidade de câmaras por filtro

4 unidades 
TABELA 31 - Principais características do meio filtrante.

MEIO FILTRANTE

Carvão antracito

Areia

Areia

Carvão antracito

Camada suporte

Velocidade de lavagem contra corrente

Velocidade de lavagem superficial

Água necessária para lavagem (10 min.)
$53 \mathrm{~cm}$

$30 \mathrm{~cm}$

Tamanho efetivo $-0,41$ a $0,45 \mathrm{~mm}$

Tamanho efetivo $-0,85$ a $0,90 \mathrm{~mm}$

Pedregulho $1 \frac{1 / 2}{2}$ a peneira $n^{\circ} .14$

$70 \mathrm{~cm} \cdot \min ^{-1}$

$10 \mathrm{~cm} \cdot \mathrm{min}^{-1}$

$108 \mathrm{~m}^{3}$

O processo de filtração permite a remoção das frações de partículas de impurezas e partículas sólidas suspensas na água que não foram removidas no decantador. A água é conduzida aos filtros através dos canais de distribuição de água decantada. A camada suporte é formada por pedregulhos em camadas de diferente granulometria. Os filtros são do tipo autolavável e cada filtro tem uma capacidade nominal de aproximadamente $45 \mathrm{~m}^{3} \cdot \mathrm{s}^{-1}$ e uma taxa de filtração contínua de $234 \mathrm{~m}^{3} \cdot \mathrm{m}^{-2} \mathrm{dia}^{-1}$. A lavagem em contra corrente do filtro é efetuada a cada 32 horas aproximadamente. A lavagem dos filtros é feita por processo automatizado levando o processo cerca de 10 minutos por filtro e movimentando um volume de água de aproximadamente $150 \mathrm{~m}^{3}$. A lavagem em contra corrente é precedida de uma lavagem superficial da camada de antracito com a finalidade de melhorar a fluidez da camada superficial. A areia, mais pesada, irá sedimentar mais rapidamente do que o antracito ao final de um período de lavagem em contra corrente. Assim, o leito do antracito está sempre no topo do leito de areia.

\subsubsection{Correção do $\mathrm{pH}$}

A alcalinização na ETA de Registro é realizada com a utilização de cal hidratada. A função da alcalinização é efetuar a correção do pH quando houver uma redução devido à ação do cloro e do sulfato de alumínio, já que participam de reação ácida. A ETA não utiliza a pré-alcalinização por não se fazer necessário e a pós-alcalinização é feita com aplicação da cal no terceiro floculador. 


\subsubsection{Fluoretação}

A SABESP utiliza o ácido fluorsilícico como agente de fluoretação da água. $O$ residual de íon fluoreto na água tratada da estação é de $0,7 \mathrm{mg} \cdot \mathrm{L}^{-1}$. O processo pelo qual se adicionam compostos de flúor nas águas de abastecimento público, para se obter o teor adequado de íon fluoreto, varia de uma região a outra, de acordo com a temperatura média das máximas anuais. Para regiões mais quentes o residual determinado é menor do que em regiões mais frias, em razão do consumo médio de água em lugares mais quentes ser maior. O objetivo da fluoretação é proporcionar aos dentes, enquanto se processa seu desenvolvimento no período de zero aos doze anos, um esmalte mais resistente e de qualidade superior, reduzindo na proporção de $65 \%$ a incidência de cárie dentária.

\subsubsection{Produtos químicos auxiliares}

A ETA de Registro não utiliza compostos auxiliares para o tratamento da água, já que a captação é feita diretamente no rio Ribeira de Iguape, rio classe 2. Na TAB.32 é apresentada uma relação de todos os produtos utilizados na ETA. A Bacia do Rio Ribeira de Iguape não contempla parque industrial e o seu meio ambiente é relativamente protegido, o que garante uma água de excelente qualidade (Marques, 2005). A ETA de Registro elabora diariamente e mensalmente relatórios sobre o funcionamento da estação.

TABELA 32 - Produtos químicos utilizados.

\section{PRODUTOS QUÍMICOS}

Tanques de armazenamento de sulfato de alumínio 1 unidade

Capacidade de armazenamento de sulfato de alumínio $20 \mathrm{~m}^{3}$

Tanques de armazenamento de cal hidratada

2 unidades

Capacidade de armazenamento de cal hidratada

$1.000 \mathrm{~L}$

Cilindros de cloro 4 unidades

Cilindro de cloro operando 1 unidade

Capacidade do cilindro de cloro. $900 \mathrm{~kg}$

Tanques de armazenamento de ácido fluorsilícico 1 unidade

Capacidade do tanque de armazenamento de acido fluorssilícico $1000 \mathrm{~L}$ 


\subsubsection{Reservação e distribuição}

A água passa por uma unidade de mistura após a filtração, onde chicanas provocam um maior contato da água com o cloro (pós-cloração) e o ácido fluorsilícico (fluoretação) da água filtrada (FIG.28). Posteriormente, ocorre o armazenamento para EEAT-ETA (estação elevatória de água tratada), num reservatório apoiado de $1.000 \mathrm{~m}^{3}$. A EEAT faz a transferência numa adutora (diâmetro de $400 \mathrm{~mm}$ ), para outros dois reservatórios apoiados e interligados de $4.500 \mathrm{~m}^{3}$, instalados num ponto alto do sistema de Registro. Os reservatórios operam conforme as pressões do sistema e podem abastecer por gravidade ou pela EEAT-SEDE e, neste caso, pressurizando a rede e gerando aproveitamento da sobra com o uso de um reservatório elevado de $500 \mathrm{~m}^{3}$.

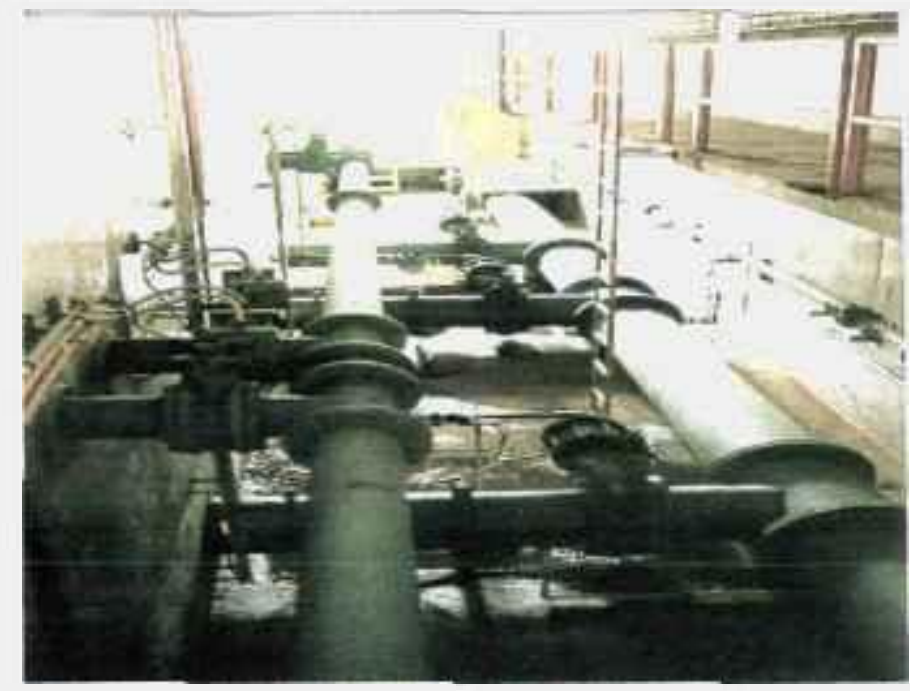

FIGURA 28 - Saída dos tanques de filtração para cloração e abastecimento.

\subsubsection{Análise dos insumos da ETA}

$\mathrm{O}$ controle químico dos insumos adicionados durante o processo de tratamento pode ser fator decisivo na qualidade da água tratada na ETA para abastecimento. Variações climáticas, como períodos de chuvas e estiagem, além de influências de atividades humanas em processos biológicos e geológicos na biosfera (Jackson et Al. 2001. Baron et al. 2003), são fatores que atuam nos constituintes químicos de rios e aquiíferos subterrâneos utilizados como fontes de captação de água, requerendo dosagens diferenciadas dos produtos químicos necessários à remoção de impurezas nas etapas de tratamento. 
No entanto, apesar de haver legislações específicas para a qualidade de água para consumo humano, não há ainda dispositivos regulatórios para a qualidade dos insumos empregados na ETA para tratamento de água quanto à presença de metais. A qualidade dos insumos utilizados nas ETAs baseia-se em parâmetros utilizados nas licitações, relacionados às normas NBR para tratamento de água (TAB.33).

TABELA 33 - Normas NBR relativas aos materiais de tratamento utilizados na ETA.

\begin{tabular}{|c|c|}
\hline NBR & Descrição da Norma \\
\hline 10.790 & $\begin{array}{l}\text { Fixa condições exigiveis de aceitação e recebimento de cal virgem e } \\
\text { cal hidratada para ETA. }\end{array}$ \\
\hline 11.176 & $\begin{array}{l}\text { Fixa condições exigiveis de aceitação e recebimento do sulfato de } \\
\text { alumínio na ETA. }\end{array}$ \\
\hline 13.293 & $\begin{array}{l}\text { Determinação de óxido de cálcio disponível, hidróxido de cálcio e } \\
\text { substâncias reativas ao } \mathrm{HCl} \text { expressa em } \mathrm{CaCO}_{3} \text { na cal virgem e na cal } \\
\text { hidratada para tratamento de água para abastecimento. }\end{array}$ \\
\hline 12.143 & Determinação de cloro ativo no hipoclorito de cálcio. \\
\hline 14.234 & ara \\
\hline
\end{tabular}

De acordo com a Portaria $n^{0} .518$ do Ministério da Saúde (Brasil, 2004) cabe à ETA o controle de qualidade dos produtos químicos utilizados em processos de tratamento de água. A ETA de Registro utiliza como insumos para o tratamento de água, o sulfato de alumínio líquido, gás cloro, ácido fluorsilícico e cal hidratada, conforme descrito anteriormente.

A verificação de qualidade é executada pelo Departamento de Controle de Qualidade, da Superintendência de Apoio Técnico da Operação da SABESP, assegurando que as especificações sejam cumpridas conforme as fichas técnicas dos fornecedores. Na TAB.34 são apresentados parâmetros adotados pela própria SABESP, para controle de sulfato de alumínio líquido (SABESP, 1993). Na TAB. 35 é mostrado o consumo da ETA de Registro, dos materiais utilizados para tratamento de água, entre novembro de 2003 e agosto de 2004 . 
TABELA 34 - Parâmetros para controle de sulfato de alumínio líquido (SABESP, 1993).

\begin{tabular}{|c|c|}
\hline $\begin{array}{c}\text { Elemento Ativo } \\
\text { (Alumínio Solúvel }-\mathbf{A l}_{\mathbf{2}} \mathbf{O}_{\mathbf{3}} \text { ) }\end{array}$ & Mín. 7,5\% \\
\hline Material Insolúvel & Máx. 0,1\% \\
\hline Ferro Solúvel $-\mathrm{Fe}_{2} \mathrm{O}_{3}$ & Máx. 1,2\% \\
\hline Acidez Livre $-\left(\mathrm{H}_{2} \mathrm{SO}_{4}\right.$ livre $)$ & Máx. $1,0 \%$ \\
\hline As & Máx. $17 \mathrm{mg} \cdot \mathrm{kg}^{-1}$ \\
\hline $\mathrm{Cd}$ & Máx. $1,7 \mathrm{mg} \cdot \mathrm{kg}^{-1}$ \\
\hline$\overline{\mathrm{Cr}}$ & Máx. 17 mg.kg ${ }^{-1}$ \\
\hline$\overline{\mathrm{Pb}}$ & Máx. 17 mg.kg ${ }^{-1}$ \\
\hline $\mathrm{Hg}$ & Máx. $0,4 \mathrm{mg} \cdot \mathrm{kg}^{-1}$ \\
\hline $\mathrm{Se}$ & Máx. 3,3 mg.kg-1 \\
\hline$\overline{\mathrm{Ag}}$ & Máx. 17 mg.kg \\
\hline Fenol & Ausente \\
\hline Detergente & Não detectável \\
\hline
\end{tabular}

Limites de toxicidade calculados para uma dosagem máxima de $300 \mathrm{mg} \cdot \mathrm{L}^{-1}$ de Sulfato de Alumínio $50 \%$.

TABELA 35 - Consumo dos insumos pela ETA de Registro.

\begin{tabular}{|c|c|c|c|c|c|}
\hline \multicolumn{6}{|c|}{ Consumo Mensal de Materiais de Tratamento da ETA de Registro - kg } \\
\hline Período & $\begin{array}{c}\text { Sulfato de } \\
\text { Alumínio Líquido }\end{array}$ & Barrilha & Cloro & $\begin{array}{c}\text { Ácido } \\
\text { Fluorsilicico } \\
\end{array}$ & $\begin{array}{c}\text { Cal } \\
\text { Hidratada }\end{array}$ \\
\hline \multicolumn{6}{|c|}{2003} \\
\hline Novembro & 19.500 & 840 & 1.300 & 854 & - \\
\hline Dezembro & 20.940 & 1.275 & 1.200 & 1.054 & - \\
\hline \multicolumn{6}{|c|}{2004} \\
\hline Janeiro & 28.381 & 2.681 & 1.359 & 1.441 & - \\
\hline Fevereiro & 24.576 & 2.179 & 1.200 & 1.194 & - \\
\hline Março & 19.855 & 967 & 900 & 1.350 & - \\
\hline Abril & 13.154 & 4.675 & 1.300 & 1.347 & - \\
\hline Maio & 12.862 & 450 & 1.168 & 1.002 & 140 \\
\hline Junho & 15.339 & - & 1.036 & 1.012 & 620 \\
\hline Julho & 15.014 & - & 843 & 1.075 & 540 \\
\hline Agosto & 11.896 & - & 896 & 1.062 & - \\
\hline Consumo Médio & 18.152 & 1.867 & 1.120 & 1.139 & 433 \\
\hline
\end{tabular}


$\mathrm{Na}$ TAB. 36 são apresentados os resultados da análise para a verificação dos teores dos principais elementos presentes no sulfato de alumínio utilizado pela ETA. Foram tomadas amostras referentes ao coagulante utilizado em três períodos (dezembro de 2003 e janeiro e abril de 2004), na saída do tubo dosador existente no tanque de floculação. Além da presença do próprio alumínio, foram detectados em ordem decrescente de concentração, $\mathrm{Fe}, \mathrm{Ca}, \mathrm{P}, \mathrm{Si}, \mathrm{Na}, \mathrm{Mg}$ e $\mathrm{Mn}$.

TABELA 36 - Caracterização química do sulfato de alumínio adicionado como coagulante (em $\mathrm{mgL}^{-1}$ ), nos meses de dezembro de 2003 e janeiro e abril de 2004.

\begin{tabular}{|c|c|c|c|}
\hline \multirow[t]{2}{*}{ Elementos } & \multicolumn{3}{|c|}{$\begin{array}{l}\text { Periodo de Amostragem do Sulfato de Alumínio e } \\
\text { Concentração }\left(\mathrm{mg}^{\left.-\mathrm{L}^{-1}\right)}\right.\end{array}$} \\
\hline & Dez/03 & Jan./04 & Abr./04 \\
\hline $\mathrm{Na}$ & 91,7 & 125 & 121 \\
\hline $\mathrm{Mg}$ & 85,3 & 112 & 92,4 \\
\hline$\overline{\mathrm{Al}}$ & 45.920 & 54.900 & 51.100 \\
\hline $\mathrm{Si}$ & 111 & 115 & 120 \\
\hline $\bar{P}$ & 144 & 178 & 154 \\
\hline $\mathrm{K}$ & 37,7 & 33,0 & 50,9 \\
\hline $\mathrm{Ca}$ & 285 & 197 & 223 \\
\hline $\bar{V}$ & 17,4 & 22,7 & 24,3 \\
\hline $\mathrm{Cr}$ & 13,8 & 21,2 & 23,0 \\
\hline $\mathrm{Mn}$ & 85,5 & 81,7 & 76,2 \\
\hline$\overline{\mathrm{Fe}}$ & 8.760 & 10.450 & 10.760 \\
\hline Co & 7,1 & 9,9 & 9,8 \\
\hline $\mathrm{Ni}$ & 6,7 & 9,0 & 9,0 \\
\hline $\mathrm{Cu}$ & 3,2 & 5,1 & 4,5 \\
\hline$\overline{\mathrm{Zn}}$ & 13,8 & 24,1 & 19,4 \\
\hline Mo & $<0.0162$ & $<0.0162$ & $<0.0162$ \\
\hline $\mathrm{Cd}$ & $<0,0008$ & $<0,0008$ & $<0,0008$ \\
\hline Sn & $<0,0146$ & $<0,0146$ & $<0,0146$ \\
\hline$\overline{\mathrm{Ba}}$ & $\overline{0,06}$ & $<0,02$ & 0,11 \\
\hline $\mathrm{Pb}$ & $<0,0196$ & $<0,0196$ & $<0,0196$ \\
\hline
\end{tabular}

\subsection{Qualidade da água bruta e monitoramento das condições climáticas}

A água bruta captada na bacia do Ribeira de lguape pela ETA, apresenta usualmente algumas características conforme é apresentado nas TAB.37 e 38 . 
TABELA 37 - Qualidade da água bruta do rio Ribeira de Iguape (na área de captação da ETA de Registro) e da água tratada, para abastecimento.

\begin{tabular}{|c|c|c|c|c|c|c|c|c|c|c|c|}
\hline \multirow{2}{*}{$\begin{array}{l}\text { Fev.-Ago. } \\
2000\end{array}$} & \multicolumn{2}{|c|}{$\begin{array}{l}\text { TURBIDEZ } \\
\text { (NTU) }\end{array}$} & \multicolumn{2}{|c|}{$\mathrm{COR}$} & \multicolumn{2}{|c|}{$\mathrm{pH}$} & \multicolumn{2}{|c|}{$\begin{array}{l}\text { ALCALINIDADE } \\
\left(\mathrm{mg}^{-1} \mathrm{~L}^{-1} \mathrm{CaCO}_{3}\right)\end{array}$} & \multirow{2}{*}{$\begin{array}{c}\begin{array}{c}\text { CLORO } \\
\left(\mathrm{mgL}^{-1}\right)\end{array} \\
\text { FINAL }\end{array}$} & \multirow{2}{*}{$\begin{array}{l}\begin{array}{l}\text { FLUOR } \\
\left(\mathrm{mg}^{\left.-\mathrm{L}^{-1}\right)}\right.\end{array} \\
\text { FINAL }\end{array}$} & \multirow{2}{*}{$\begin{array}{l}\begin{array}{c}\mathrm{COAG} \\
\left(\mathrm{mgl}^{-1}\right)\end{array} \\
\text { FINAL }\end{array}$} \\
\hline & BRUTA & FINAL & BRUTA & FINAL & BRUTA & FINAL & BRUT A & FINAL & & & \\
\hline Média & 26 & 0,4 & 88 & $<5,0$ & 7.3 & 7,2 & 23 & 22 & 1,7 & 0.7 & 27 \\
\hline Desvio & 35 & 0,3 & 98 & - & 0,2 & 0,2 & 2,5 & 4.3 & 0,4 & 0,1 & 8,0 \\
\hline Máximo & 200 & 1,8 & 500 & 7,5 & 7,6 & 7,8 & 30 & 34 & 3,6 & 1,0 & 63 \\
\hline Mínimo & 4,0 & 0,1 & 30 & 7,5 & 6,4 & 6,7 & 15 & 3,0 & 0,7 & 0,1 & 17 \\
\hline
\end{tabular}

Dados: SABESP - UNIDADE DE NEGÓCIO - VALE DO RIBEIRA - LR

Na FIG.29 é mostrado o perfil de algumas variáveis climáticas da região de Registro como a temperatura média e indice pluviométrico, bem como parâmetros de qualidade da água captada no rio Ribeira de Iguape, como a turbidez, além do volume diário de água captada para tratamento, no periodo de outubro de 2003 e janeiro de 2004.

TABELA 38 - Teor de metais na água bruta do rio Ribeira de Iguape (na área de captação da ETA de Registro).

\begin{tabular}{cccccccc}
\hline \multirow{2}{*}{ Periodo } & \multicolumn{7}{c}{ Concentração (mg.L $\left.\mathbf{- 1}^{-1}\right)$} \\
\cline { 2 - 8 } & $\mathbf{B a}$ & $\mathbf{C d}$ & $\mathbf{P b}$ & $\mathbf{C u}$ & $\mathbf{C r}$ & $\mathbf{A g}$ & $\mathbf{Z n}$ \\
\hline $21 / 02 / 2000$ & $<0,2$ & $<0,002$ & $<0,02$ & $<0,030$ & $<0,005$ & $<0,002$ & $<0,010$ \\
\hline $28 / 08 / 2000$ & $<0,2$ & $<0,002$ & $<0,02$ & $<0,030$ & 0,007 & $<0,002$ & $<0,010$ \\
\hline $05 / 04 / 1999$ & $<0,2$ & $<0,002$ & $<0,02$ & $<0,030$ & $<0,005$ & $<0,002$ & 0,011 \\
\hline $19 / 07 / 1999$ & $<0,2$ & $<0,002$ & $<0,02$ & $<0,030$ & $<0,005$ & $<0,002$ & $<0,010$ \\
\hline $11 / 05 / 1998$ & $<0,2$ & $<0,002$ & $<0,02$ & $<0,030$ & $<0,005$ & $<0,002$ & $<0,010$ \\
\hline $01 / 10 / 1998$ & $<0,2$ & $<0,002$ & $<0,02$ & $<0,030$ & $<0,005$ & $<0,002$ & $<0,010$ \\
\hline
\end{tabular}

Dados: SABESP - UNIDADE DE NEGÓCIO - VALE DO RIBEIRA - LR

De acordo com os resultados apresentados e considerando um volume de captação de água praticamente constante, foi observado que os niveis de turbidez da água de captação apresentam um crescimento proporcional ao aumento do índice pluviométrico no período. $O$ intuito dessa avaliação foi verificar uma relação direta entre $o$ índice pluviométrico da região com a turbidez da água tratada, em razão da desagregação e transporte de partículas constituintes do solo para o rio Ribeira de Iguape, relacionando-os com o volume de água captada para o tratamento. 
$\mathrm{Na}$ TAB.39 é relacionado o volume de coagulante adicionado ao processo com o nível de precipitação pluviométrica. Verifica-se que o período de menor consumo do sulfato de alumínio é também caracterizado por um menor índice pluviométrico, embora a região apresente um alto índice de pluviosidade, mesmo nas épocas de estiagem.

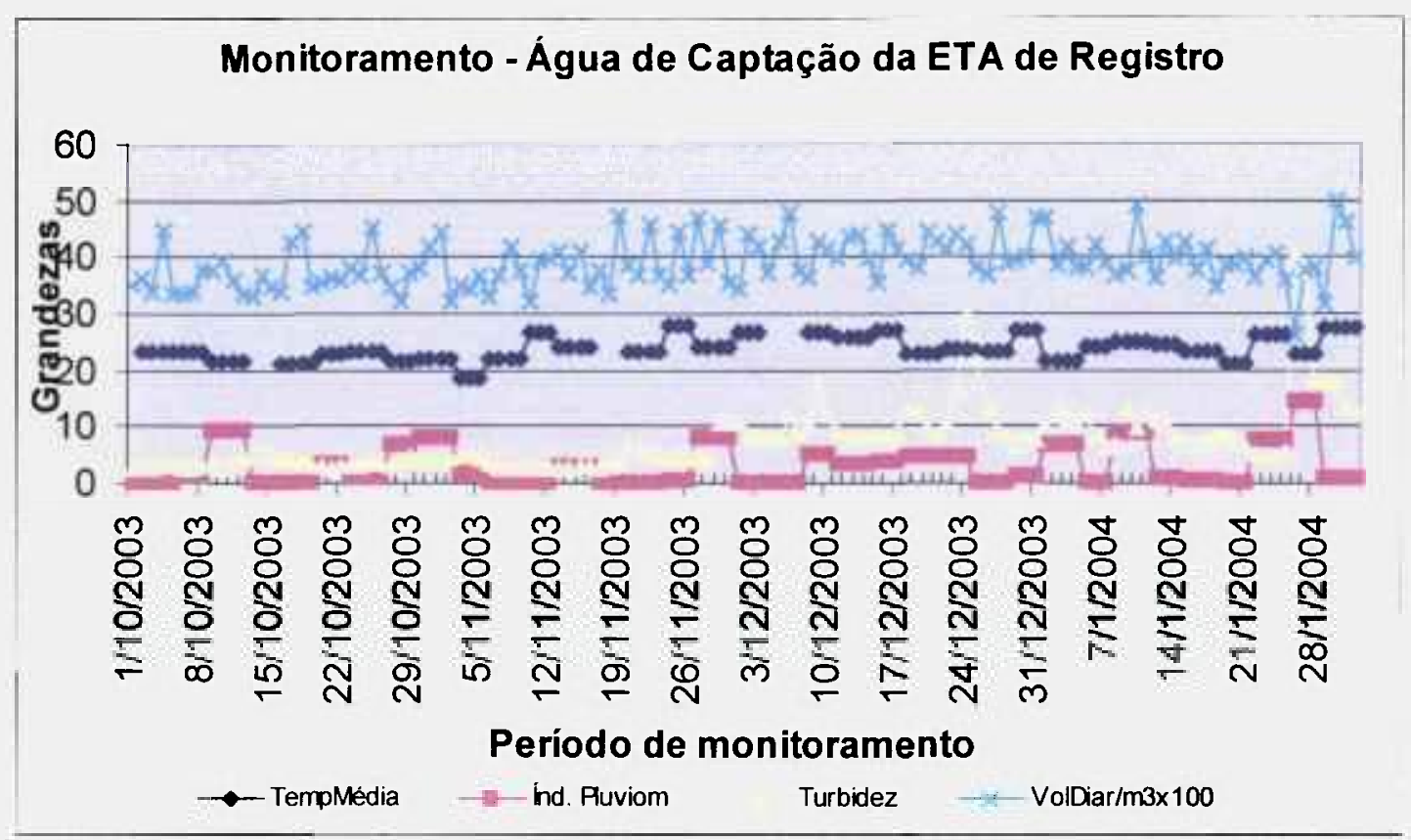

FIGURA 29 - Perfil das condições ambientais: temperatura média $\left({ }^{\circ} \mathrm{C}\right)$ e índice pluviométrico $(\mathrm{mm})$ com relação à turbidez da água bruta e volume de água tratado da ETA de Registro $\left(\mathrm{m}^{3}\right)$, no período de março de 2003 a janeiro de 2004.

Foi observado que embora haja uma tendência entre uma maior quantidade de coagulante adicionado no processo de tratamento para um maior índice pluviométrico da região, esta relação não foi direta em alguns períodos. A comparação entre os dados observados entre novembro de 2003 e dezembro de 2004, por exemplo, mostram que níveis de precipitação na região podem não ser decisivos na avaliação da quantidade do coagulante requerido pela ETA e, consequentemente, no volume de lodo gerado.

O fato do rio Ribeira de Iguape drenar boa parte da bacia hidrográfica, que apresenta em alguns locais um alto índice de pluviosidade ao longo de todo o ano, pode explicar porque, às vezes, em épocas intermediárias às estações de chuvas e estiagem, se 
observam na ETA de Registro níveis relativamente constantes de adição de coagulante pela ETA, mesmo com a diminuição dos níveis de precipitação na região de Registro. Tal fato também pode explicar porque a quantidade de coagulante adicionado não é diretamente proporcional ao índice de chuvas da cidade da região de Registro.

TABELA 39 - Condições climáticas da cidade de Registro no período de 01/11/2003 a $31 / 12 / 2004$ e quantidades de sulfato de alumínio adicionado como coagulante.

\begin{tabular}{|c|c|c|c|c|c|c|}
\hline Mes & $\begin{array}{l}\text { Temperatura } \\
\text { Máxima } \\
\text { Mensal } \\
\left.\text { ( }{ }^{\circ} \mathrm{C}\right)\end{array}$ & $\begin{array}{l}\text { Temperatura } \\
\text { Mínima } \\
\text { Mensal } \\
\left.\text { ( }{ }^{\circ} \mathrm{C}\right)\end{array}$ & $\begin{array}{c}\text { Temperatura } \\
\text { Media } \\
\left.\text { ( }{ }^{\circ} \mathrm{C}\right)\end{array}$ & $\begin{array}{l}\text { Niveis de } \\
\text { Precipitaçäo } \\
\text { (mm) }\end{array}$ & $\begin{array}{l}\text { Dias } \\
\text { chuvosos }\end{array}$ & $\begin{array}{c}\text { Coagulante } \\
(\mathbf{k g})\end{array}$ \\
\hline & & & 2003 & & & \\
\hline Novembro & 28,7 & 18,9 & 23,8 & 118,6 & 12 & 19.500 \\
\hline \multirow[t]{2}{*}{ Dezembro } & 29,9 & 20,7 & 25,3 & 123,4 & 15 & 20.940 \\
\hline & & & 2004 & & & \\
\hline Janeiro & 27,7 & 20,4 & 24,0 & 408,4 & 16 & 28.381 \\
\hline Fevereiro & 30,2 & 20,2 & 25,2 & 200,8 & 17 & 24.576 \\
\hline Março & 28,7 & 19,6 & 24,2 & 152,9 & 16 & 19.855 \\
\hline Abril & 28,7 & 19,9 & 24,3 & 77,9 & 13 & 13.154 \\
\hline Maio & 23,6 & 15,6 & 19,6 & 78,8 & 14 & 12.862 \\
\hline Junho & 23,0 & 14,7 & 18,9 & 43,1 & 7 & 15.339 \\
\hline Julho & 22,3 & 14,0 & 18,2 & 120,7 & 14 & 15.014 \\
\hline Agosto & 24,9 & 13,6 & 19,3 & 6,3 & 7 & 11.896 \\
\hline Setembro & 27,2 & 17,7 & 22,4 & 18,1 & 7 & 14.230 \\
\hline Outubro & 26,1 & 16,7 & 21,4 & 142,3 & 12 & 18.364 \\
\hline Novembro & 27,7 & 19,3 & 23,5 & 142,4 & 15 & 18.797 \\
\hline Dezembro & 28,5 & 19,9 & 24,2 & 351,8 & 22 & 18.863 \\
\hline
\end{tabular}

Pode-se concluir, portanto, que o índice de pluviosidade apresentado em uma bacia hidrográfica pode ter uma influência direta no volume de lodo formado na ETA. No entanto, a incidência de chuvas na região pode ser um fator positivo quando se considera a dispersão do lodo descartado. Chuvas intensas podem dispersar rapidamente os resíduos sólidos da ETA presentes no rio, minimizando o impacto local, principalmente em rios de pequena vazão, como o rio Sem Nome, que recebe diretamente as descargas da ETA.

O estudo das características do lodo formado nos tanques de decantação e de amostras recolhidas no rio receptor dos despejos do lodo é, portanto, uma importante ferramenta para se avaliar a influência do descarte na qualidade da água da Bacia do rio Ribeira de Iguape. A quantidade de lodo produzido pela ETA foi estimada, baseando-se em fórmulas empíricas encontradas na literatura (Reali, 2003). 
Na TAB. 40 são apresentados os resultados obtidos no período de estudo de acordo com a equação (10), considerando o uso de sulfato de alumínio como coagulante.

Massa $(\mathrm{g})$ de sólidos $/ \mathrm{m}^{3}$ de água tratada $=\left[\right.$ Dosagem de sulfato de alumínio (mg. $\mathrm{L}^{-1}$ ) $\mathrm{x}$ $\left.0,26^{*}\right]+\left[\right.$ Turbidez da água bruta (uT) x $\left.1,5^{* *}\right]$

Onde:

*Fator que depende do número de moléculas de $\mathrm{H}_{2} \mathrm{O}$ associadas a cada molécula de sulfato de aluminio (geralmente varia de 0,23 a 0,26 ).

**Razão entre a concentração de sólidos suspensos totais presentes na água bruta e a turbidez da mesma (geralmente na faixa de 1,0 a 2,0).

A produção média de sólidos estimada para o periodo, de acordo com os dados da TAB.40, foi de um valor aproximado de $15,6 \mathrm{~g} \cdot \mathrm{m}^{-3}$. Comparando-se com a TAB.41, podese verificar que, em relação a este parâmetro, o pouco impacto do rio Ribeira de Iguape na produção de sólidos pela ETA, deve-se à boa qualidade da água de captação (Reali, 1999).

TABELA 40 - Estimativa da quantidade de lodo gerado pela ETA de Registro, no periodo de Nov./2003 e Ago./2004, a partir da média mensal de alguns parâmetros.

\begin{tabular}{|c|c|c|c|c|c|c|}
\hline Mês & $\begin{array}{c}\text { Volume } \\
\text { Água } \\
\text { Tratada } \\
\text { Produzida } \\
\left(\mathrm{m}^{3}\right)\end{array}$ & $\begin{array}{l}\text { Horas } \\
\text { Médias de } \\
\text { Atividade } \\
\text { (mês) }\end{array}$ & $\begin{array}{l}\text { Coagulante } \\
(\mathrm{kg})\end{array}$ & $\begin{array}{l}\text { Niveis de } \\
\text { Turbidez } \\
\text { (NTU)* }\end{array}$ & $\begin{array}{l}\text { Níveis de } \\
\text { Sólidos } \\
\text { Totais* } \\
\text { (mg.L-1) }\end{array}$ & $\begin{array}{l}\text { Massa grama } \\
\text { de sólidos. } \mathrm{m}^{-3} \\
\text { de água } \\
\text { tratada }\end{array}$ \\
\hline \multicolumn{7}{|c|}{2003} \\
\hline Novembro & 288.734 & $16: 30$ & 19.500 & - & - & - \\
\hline Dezembro & 318.381 & $17: 00$ & 20.940 & $35^{* *}$ & $178^{* *}$ & 17,3 \\
\hline \multicolumn{7}{|c|}{2004} \\
\hline Janeiro & 293.296 & $16: 18$ & 28.381 & $24-42$ & $86-148,5$ & 25,2 \\
\hline Fevereiro & 287.911 & 17:00 & 24.576 & $24-40$ & $118-121$ & 22,3 \\
\hline Março & 314.587 & $17: 36$ & 19.855 & $21-85$ & $182-201$ & 16,6 \\
\hline Abril & 300.890 & $17: 20$ & 13.154 & $45-110$ & $152-226$ & 11,6 \\
\hline Maio & 297.439 & $16: 55$ & 12.862 & $14-16$ & $202-374$ & 11,5 \\
\hline Junho & 271.144 & $16: 46$ & 15.339 & $30-83$ & $160-210$ & 14,9 \\
\hline Julho & 312.940 & $16: 20$ & 15.014 & $20-70$ & $92-237$ & 12,6 \\
\hline Agosto & 297.367 & $14: 27$ & 11.896 & $6,7-6,75$ & $100-106$ & 10,5 \\
\hline
\end{tabular}


TABELA 41 - Impactos típicos do tipo de manancial sobre a produção de resíduos (Reali, 1999).

\begin{tabular}{|c|c|}
\hline Tipo de Manancial & $\begin{array}{c}\text { Faixa de Produção de Resíduos (g de } \\
\text { sólidos Secos por } \mathrm{m}^{3} \text { de Água Tratada) }\end{array}$ \\
\hline Água de reservatório com boa qualidade & $12-18$ \\
\hline Água de reservatório com média qualidade & $18-30$ \\
\hline Água de rios com qualidade média & $24-36$ \\
\hline Água de reservatórios com qualidade ruim & $30-42$ \\
\hline Água de rios com qualidade ruim & $42-54$ \\
\hline
\end{tabular}

\subsection{Caracterização Química do Lodo de ETA}

As amostras de lodo foram caracterizadas com o objetivo de avaliar possíveis alterações na composição do lodo nas diferentes estações de seca e chuva. Uma avaliação preliminar demonstrou que todas as amostras apresentaram uma certa uniformidade no aspecto físico gelatinoso, além de uma tonalidade marrom, como conseqüência do uso de sulfato de alumínio como coagulante. Na TAB.42 apresentam-se os resultados obtidos para os parâmetros físico-químicos utilizados para a caracterização das amostras de lodo coletado no fundo do decantador, no período entre fevereiro e setembro de 2004.

Os resultados mostraram que o $\mathrm{pH}$, a densidade e a algumas propriedades físicoquímicas das amostras de lodo recolhido dos decantadores permaneceram relativamente invariáveis e características, apesar da qualidade da água de captação ter requerido por parte da ETA, quantidades variáveis de coagulante necessários ao seu tratamento, especialmente em função de suas características fisico-químicas bem definidas entre os periodos de chuvas e estiagem, influenciada pelas variações das condições meteorológicas observadas no período de estudo e listadas na TAB.39 (CIIAGRO, 2004). Tal fato sugere que alguns aspectos do lodo podem ser característicos de uma ETA em virtude das condições ambientais no seu entorno, além das etapas específicas do processo de tratamento, conforme também constatado pelo estudo de algumas características dos lodos gerados em diferentes ETAs por PROSAB (1999). 
TABELA 42 - Resultados obtidos a partir dos principais parâmetros físico-químicos avaliados nas amostras de lodo.

\begin{tabular}{|c|c|c|c|c|c|}
\hline \multicolumn{6}{|c|}{ FAIXA DE CONCENTRAÇÃO DE PARÂMETROS MEDIDOS EM LO } \\
\hline \multicolumn{6}{|c|}{ DECANTADOR (MATERIAL ORIGINAL) } \\
\hline & $\begin{array}{c}\text { Amostra } 1 \\
\text { (Fev./2004) }\end{array}$ & $\begin{array}{l}\text { Amostra } 2 \\
(\mathrm{Abr} . / 2004)\end{array}$ & $\begin{array}{l}\text { Amostra } 3 \\
\text { (Jun./2004) }\end{array}$ & $\begin{array}{l}\text { Amostra } 4 \\
\text { (Set./2004) }\end{array}$ & Faixa Média \\
\hline $\mathrm{pH}$ & 6,13 & 5,94 & 6,46 & 6,30 & $5,94-6,46$ \\
\hline Turbidez (NTU) & $>1.000$ & $>1.000$ & $>1.000$ & $>1.000$ & $>1.000$ \\
\hline Alcalinidade $\left(\mathrm{mg} \mathrm{CaCO}_{3}\right)$ & 450 & 220 & 674 & 584 & $220-674$ \\
\hline Sólidos Sedimentáveis (mL. $\left.\mathrm{L}^{-1}\right)$ & 1.000 & 1.000 & 1.000 & 1.000 & 1.000 \\
\hline Densidade (mg. $\mathrm{L}^{-1}$ ) & 1.075 & 1.080 & 1.075 & 1.095 & $1.075-1.095$ \\
\hline$\%$ Umidade $\left(60^{\circ} \mathrm{C}\right)$ & 12,23 & 11,39 & 13,16 & * & $11,39-13,16$ \\
\hline $\begin{array}{c}\text { Perda ao Fogo (\%) } \\
9900^{\circ} \mathrm{C}(4 \mathrm{~h})\end{array}$ & 25,80 & - & - & 24,80 & $24,80-25,80$ \\
\hline
\end{tabular}

Apesar de não ter sido suficiente para alterar significativamente parâmetros como densidade e umidade, um aumento na quantidade de um coagulante à base de sulfato de alumínio pode, porém, influenciar diretamente nas medidas de alcalinidade e $\mathrm{pH}$ do lodo, especialmente em função da formação de hidróxido de alumínio na etapa de coagulação e floculação, conforme visto nas equações 1 e 2 (item 3.3). A adição de corretores de pH durante o processo de tratamento de água pode, por outro lado, minimizar este efeito alcalino.

\subsubsection{Caracterização física e geomorfológica das amostras de lodo}

A análise preliminar da composição química do lodo da ETA foi realizada em amostras previamente calcinadas a $900^{\circ} \mathrm{C}$, utilizando-se a técnica de Fluorescência de Raios X (WDXRF - Philips - Magic Pro Model). De acordo com os resultados, podemos observar que os principais constitutintes são a sílica e o alumínio, seguidos dos elementos ferro e manganês (Reis et al., 2004). A TAB.43 apresenta também uma comparação dos resultados das análises de amostras de lodo da ETA de Registro com amostras de lodo de ETAs provenientes de diferentes sistemas de tratamento de água, pertencentes a Bacia Hidrográfica do Ribeira de Iguape. 
TABELA 43. Caracterização semi-quantitativa por FRX, de amostras de lodo proveniente de diferentes ETAs pertencentes à bacia hidrográfica do rio Ribeira de Iguape.

\begin{tabular}{|c|c|c|c|c|c|}
\hline \multirow{3}{*}{$\begin{array}{c}\text { Composiçāo } \\
\text { Química }\end{array}$} & \multicolumn{5}{|c|}{ Concentração $(\%)^{*}$} \\
\hline & \multicolumn{2}{|c|}{ Lodo ETA Registro } & \multirow{2}{*}{$\begin{array}{c}\text { Lodo ETA } \\
\text { Pariqueraçu }\end{array}$} & \multirow{2}{*}{$\begin{array}{l}\text { Lodo ETA } \\
\text { S. Lourenço da } \\
\text { Serra }\end{array}$} & \multirow{2}{*}{$\begin{array}{c}\text { Lodo ETA } \\
\text { Juquitiba }\end{array}$} \\
\hline & Fev./2004 & Ago./2004 & & & \\
\hline $\mathrm{SiO}_{2}$ & 31,5 & 32.5 & 28,4 & 19.6 & 24,2 \\
\hline$\overline{\mathrm{Al}_{2} \mathrm{O}_{3}}$ & 23,7 & 23,8 & 21,1 & 25,5 & 27,8 \\
\hline $\mathrm{Fe}_{2} \mathrm{O}_{3}$ & 11.8 & 11,4 & 11,7 & 17,1 & 16,0 \\
\hline $\mathrm{K}_{2} \mathrm{O}$ & 2,6 & 2,7 & 2,6 & 1,5 & 2,1 \\
\hline $\mathrm{TiO}_{2}$ & 1,0 & 1,2 & 0,96 & 0,79 & 0,85 \\
\hline $\mathrm{MgO}$ & 0,95 & 1,0 & 0,41 & 0,39 & 0,21 \\
\hline $\mathrm{SO}_{3}$ & 0,93 & 0,68 & 1,2 & 0,76 & 0,54 \\
\hline $\mathrm{CaO}$ & 0,35 & 0,59 & 0,075 & $0, \overline{25}$ & 0,094 \\
\hline $\mathrm{Cl}$ & $0, \overline{37}$ & 0,46 & 0,095 & 0,52 & 0,16 \\
\hline $\mathrm{P}_{2} \mathrm{O}_{5}$ & 0,42 & 0,46 & 0,29 & 0,52 & 0,38 \\
\hline $\mathrm{Na}_{2} \mathrm{O}$ & 0,21 & 0,27 & 0,17 & 0,10 & 0,10 \\
\hline $\mathrm{MnO}$ & 0,18 & 0,17 & 0,062 & 0,46 & 0,44 \\
\hline $\mathrm{Cr}_{2} \mathrm{O}_{3}$ & 0,029 & 0,033 & 0,022 & 0,015 & 0,019 \\
\hline $\mathrm{Rb}_{2} \mathrm{O}$ & 0,018 & 0,027 & 0,006 & 0,003 & 0,003 \\
\hline $\mathrm{NiO}$ & 0,013 & 0,015 & 0,008 & 0,007 & 0,012 \\
\hline $\mathrm{PbO}$ & - & 0,014 & - & - & 0,019 \\
\hline $\mathrm{ZnO}$ & 0,020 & 0,023 & 0,009 & 0,013 & 0,013 \\
\hline $\mathrm{Br}$ & 0,008 & 0.012 & $\overline{0,011}$ & $0, \overline{048}$ & 0,011 \\
\hline $\mathrm{CuO}$ & 0.013 & 0.011 & 0,006 & 0,008 & 0,010 \\
\hline $\mathrm{SrO}$ & 0,005 & 0,009 & 0,002 & 0,001 & 0.002 \\
\hline $\mathrm{ZrO}_{2}$ & 0,007 & 0,008 & $\overline{0,008}$ & 0.009 & 0.005 \\
\hline $\mathrm{Ga}_{2} \mathrm{O}_{3}$ & 0,008 & 0,008 & 0,005 & 0,005 & 0,010 \\
\hline $\mathrm{Nb}_{2} \mathrm{O}_{5}$ & 0.0005 & 0.0004 & 0.0005 & 0.0009 & 0.0005 \\
\hline$\overline{\mathrm{V}_{2} \mathrm{O}_{5}}$ & - & - & - & 0,044 & 0,043 \\
\hline$\overline{\mathrm{As}_{2} \mathrm{O}_{3}}$ & - & - & $0, \overline{004}$ & 0,006 & - \\
\hline $\mathrm{Y}_{2} \mathrm{O}_{3}$ & - & $\overline{-}$ & $\overline{-}$ & 0,002 & $\overline{-}$ \\
\hline Perda ao Fogo & 25.8 & 25,8 & 32,8 & 32,4 & 26.9 \\
\hline
\end{tabular}

*Amostra previamente seca a $55-60^{\circ} \mathrm{C}$ e calcinada a $900^{\circ} \mathrm{C}$ por 1 hora. 
Todas as amostras, após serem secas a $55-60^{\circ} \mathrm{C}$, foram previamente calcinadas a 900 ${ }^{\circ} \mathrm{C}$ por 4 horas e avaliadas por análises semi - quantitativa por meio de parâmetros fundamentais com ensaio direto não destrutivo por espectrofluorimetria de fluorescência de raios $\mathrm{X}$ (WDXRF), utilizando pastilha prensada.

Muito embora elementos como ferro, cálcio, magnésio e potássio possam ser geralmente relacionados a espécies químicas comumente constituintes de águas superficiais de cursos d'água, a bacia do rio Ribeira de Iguape é constituida por uma ampla variedade de substâncias derivadas de minerais ferrosos, metálicos e preciosos, além de prata, antimônio e terras raras, caracterizando a presença destes metais (Hogan, 2002). Todas essas substâncias podem estar presentes na água bruta e conseqüentemente na fase sólida do lodo, em função das propriedades coagulantes do hidróxido de alumínio produzido na reação de hidrólise do sulfato de aluminio.

\subsubsection{Avaliação mineralógica}

A avaliação mineralógica das amostras de lodo previamente maceradas foi realizada utilizando-se a técnica de espectrometria de Difração de Raios X. Foi utilizado um difratômetro de raios X da Brucker - AXS D8 Model - Advance, com radiação monocromática $\mathrm{Cu}_{\mathrm{k \alpha}} \operatorname{com} 40 \mathrm{kV}$ e $40 \mathrm{~mA}$, sob um ângulo $2 \theta$ de $3^{\circ}$ até $90^{\circ}$. As fases foram identificadas com o auxilio dos dados listados pelo Joint Commitee of Powder Diffraction Standards (JCPDS, 1997). Foram analisadas amostras coletadas em dois períodos distintos (fevereiro/2004 e agosto/2004).

Nestas condições, quartzo $\left(\mathrm{SiO}_{2}\right)$ e caulinita $\left(2 \mathrm{SiO}_{2} \cdot \mathrm{Al}_{2} \mathrm{O}_{3} \cdot 2 \mathrm{H}_{2} \mathrm{O}\right)$ foram identificados como espécies cristalográficas dominantes, em razão da presença de picos bem definidos conforme apresentados nas FIG. 30 e 31 (intensidade relativa versus $2 \theta$ ). Os picos principais foram detectados a $2 \theta=20.85^{\circ}$ e $2 \theta=26.65^{\circ}\left(\mathrm{SiO}_{2}\right)$, e com uma distância de $\mathrm{d}=4,26 \mathrm{~A}^{\mathrm{o}}$ e $\mathrm{d}=3,34 \mathrm{~A}^{\mathrm{o}}$, respectivamente. A presença predominante de sílica detectada nas amostras de lodo deve-se à presença de quartzitos na região. A banda larga observada entre $2 \theta=20^{\circ}$ e $2 \theta=30^{\circ}$ pode ser atribuída à presença de material amorfo. As análises para a avaliação da morfologia das mesmas amostras, foram realizadas por microscopia eletrônica de varredura (Philips XL-30 Model). 
Nas FIG. 32 e 33 são mostradas fotomicrografias eletrônicas de varredura das superficies das partículas de lodo de ETA. Os resultados mostraram a predominância de sílica (quartzo) nos grãos, apresentando detalhes morfológicos essencialmente homogêneos entre as amostras avaliadas.
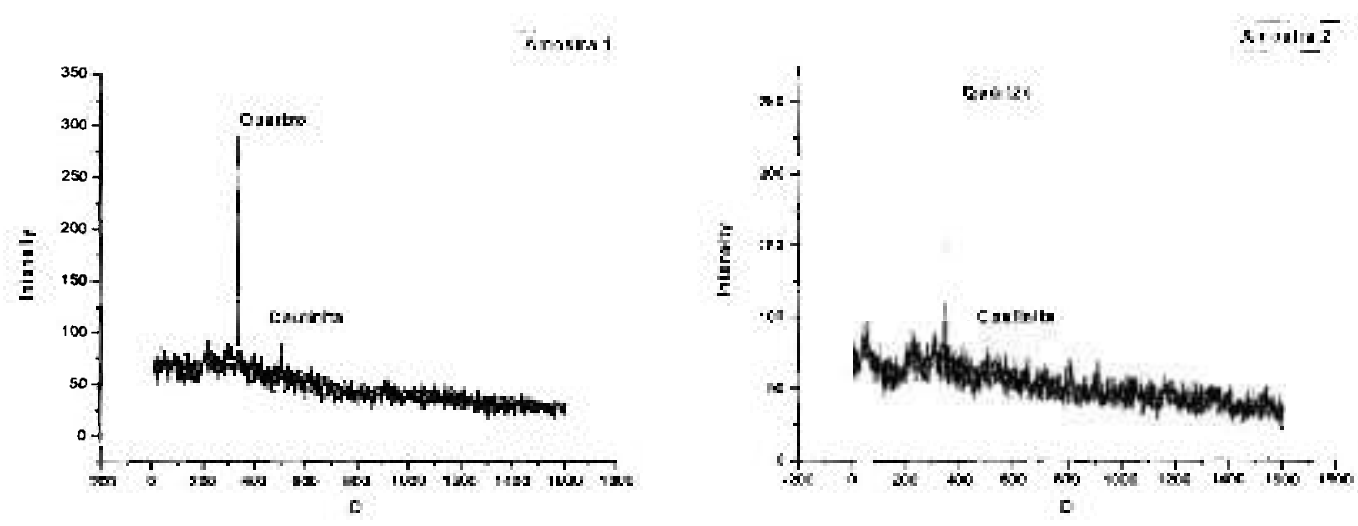

FIGURAS 30 e 31 - Difratograma de duas amostras de lodo de ETA coletadas em periodos de chuvas e estiagem ( fevereiro e agosto de 2004 , respectivamente).

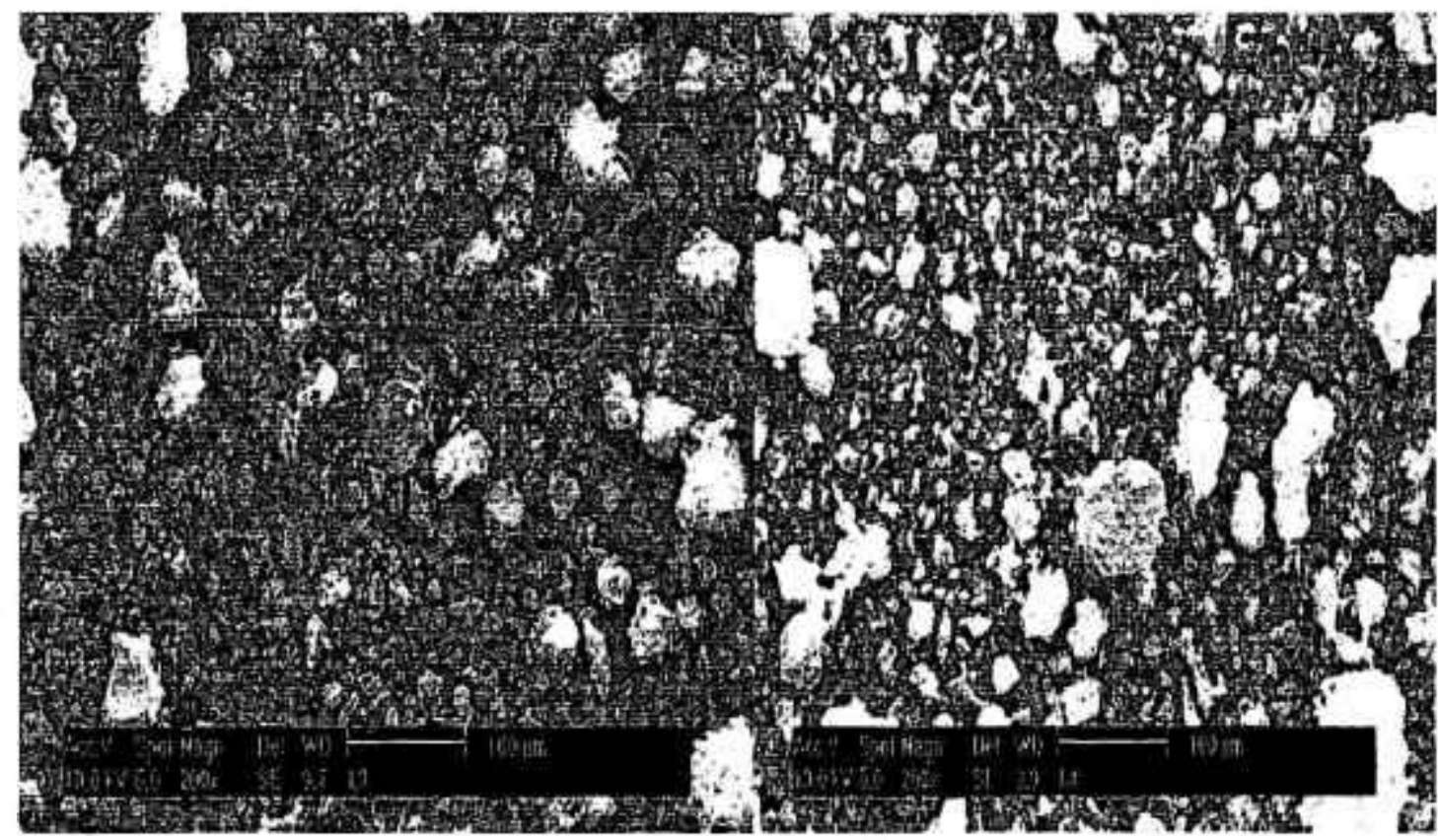

Figura 32 - Amostra 1 (Fev-2004)

Figura 33 - Amostra 2 (Ago/ 2004)

Figuras 32 e 33: Fotomicrografia eletrônica de varredura, mostrando detalhes morfológicos (SEM - 10.000x) das partículas de lodo de ETA. 
Os métodos de difração (difração de raios $X$, difração de nêutrons e difração de elétrons) são de grande importância na análise microestrutural dos materiais. Esses métodos fornecem informações sobre a natureza e os parâmetros do reticulado, assim como detalhes a respeito do tamanho, da perfeição e da orientação dos cristais. As técnicas de difração de nêutrons e difração de elétrons são utilizadas atualmente quase que exclusivamente em conjunto com a microscopia eletrônica (Padilha, Ambrosio Filho, 1985).

A microscopia eletrônica de varredura é um dos mais versáteis instrumentos disponiveis para o exame e análise microestrutural caracteristicos de objetos sólidos. $\dot{E}$ efetiva de submicron até centenas de micra e, em geral, medem-se apenas algumas dezenas ou centenas de partículas (Goldstein, Yakowitz, Newbury; 1997). As imagens de microscopia eletrônica expostas nas FIG. 32 e 33 mostram, em detalhe, a textura das partículas. Uma avaliação complementar por análise química por energia dispersiva (EDX), confirmou que a composição química predominante é de Si e $\mathrm{Al}$, complementada por Fe, $\mathrm{Mg}, \mathrm{K}$, As e Mn. Amostras de lodo da ETA coletadas em períodos de chuvas e estiagem apresentam perfis relativamente estáveis, com concentrações e razões das espécies químicas identificadas relativamente equivalentes. No entanto, diferenças observadas com relação ao silício, por exemplo, devem-se provavelmente a um maior carreamento do solo na região, em virtude da diferença na incidência de chuvas, influenciando na composição da água de captação e, portanto, no lodo produzido pela ETA.

\subsubsection{Caracterização dos metais lixiviáveis no lodo}

Os resultados obtidos da determinação de metais e elementos-traço presentes nas amostras de lodo seco podem ser observados na TAB.44, referentes às amostras de lodo coletadas nos meses de dezembro de 2003, janeiro e fevereiro de 2004. Com base na caracterização prévia das amostras de lodo pela técnica de fluorescência de raios $\mathrm{X}$, foram determinados os elementos nas frações de digestão total, parcial e lixiviável do lodo de ETA, conforme descrito anteriormente, por meio de análise por ICP-OES. A análise dessas frações no lodo gerado tem grande importância, principalmente por causa dos possiveis efeitos gerados pela presença de metais tóxicos nos despejos. Deste modo, o potencial poluente de resíduos sólidos pode ser verificado em função da determinação das diversas frações dos metais associados a estes residuos. 
TABELA 44 - Concentrações médias dos analitos (mg. $\left.\mathrm{kg}^{-1}\right)$ em diferentes frações de digestão, em amostras de lodo seco, por período de coleta.

\begin{tabular}{|c|c|c|c|c|c|c|c|c|c|c|}
\hline \multicolumn{11}{|c|}{ Concentração Base Seca (mg.kg } \\
\hline \multirow{2}{*}{\multicolumn{2}{|c|}{ Elementos }} & \multicolumn{3}{|c|}{ Dez/2003 } & \multicolumn{3}{|c|}{$\mathrm{Jan} / 2004$} & \multicolumn{3}{|c|}{ Fev/2004 } \\
\hline & & Total & Parcial & Lixiv. & Total & Parcial & Lixiv. & Total & Parcial & Lixiv. \\
\hline \multirow[t]{2}{*}{$\mathbf{N a}$} & Média & 55.797 & 2.717 & 18,0 & 49.156 & 3.018 & 23,2 & 43.484 & 5.259 & 7,54 \\
\hline & Desvio & 2.825 & 974 & 4,74 & 13.797 & 950 & 12,9 & 10.018 & 2.183 & 1,19 \\
\hline \multirow[t]{2}{*}{$\mathrm{Mg}$} & Média & 3.570 & 2.669 & 537 & 2.410 & 2.349 & 371 & 2.002 & 2.489 & 369 \\
\hline & Desvio & 481 & 64 & 9,0 & 340 & 35 & 22 & 347 & 87 & 16 \\
\hline \multirow[t]{2}{*}{$\mathbf{P}$} & Média & 960 & 785 & 603 & 980 & 839 & 589 & 952 & 839 & 673 \\
\hline & Desvio & 103 & 28 & 49 & 14 & 20 & 95 & 47 & 22 & 33 \\
\hline \multirow[t]{2}{*}{$\mathbf{K}$} & Média & 11.359 & 1.220 & 133 & 9.679 & 1.708 & 163 & 8.502 & 2.348 & 134 \\
\hline & Desvio & 1.085 & 1.031 & 3,0 & 1.187 & 206 & 17 & 645 & 432 & 10 \\
\hline \multirow[t]{2}{*}{$\mathbf{C a}$} & Média & 2.101 & 1.681 & 2.780 & 1.599 & 1.383 & 2.372 & 788 & 1.178 & 1.854 \\
\hline & Desvio & 182 & 28 & 29 & 919 & 26 & 116 & 132 & 98 & 23 \\
\hline \multirow[t]{2}{*}{$\mathrm{Fe}$} & Média & 46.921 & 41.956 & 8.753 & 49.233 & 44.956 & 12.479 & 48.369 & 46.662 & 9.689 \\
\hline & Desvio & 4.931 & 793 & 554 & 832 & 957 & 1821 & 796 & 1253 & 246 \\
\hline \multirow[t]{2}{*}{$\mathrm{Ba}$} & Média & 802 & 315 & 153 & 602 & 268 & 120 & 428 & 306 & 126 \\
\hline & Desvio & 78 & 6,0 & 2,0 & 189 & 8,0 & 7,0 & 85 & 19 & 2,0 \\
\hline \multirow[t]{2}{*}{ Co } & Média & 80,7 & 60,7 & 8,20 & 79,0 & 63,4 & 9,78 & 77,5 & 66,3 & 754 \\
\hline & Desvio & 8,96 & 1,60 & 1,39 & 1,96 & 1,25 & 5,80 & 1,51 & 2,27 & 0,59 \\
\hline \multirow[t]{2}{*}{$\mathbf{A l}$} & Média & 91.310 & 53.278 & 52011 & 83.067 & 70.368 & 79244 & 59.835 & 65.547 & 66.111 \\
\hline & Desvio & 12.089 & 2.390 & 1.869 & 377 & 1.881 & 4799 & 5.510 & 6.016 & 1052 \\
\hline \multirow[t]{2}{*}{$v$} & Média & 109 & 71,6 & 24,6 & 117 & 85,8 & 42,1 & 120 & 86,2 & 34,9 \\
\hline & Desvio & 11,7 & 1,9 & 1,8 & 5.5 & 1,0 & 7,4 & 3,1 & 2,4 & 0,9 \\
\hline \multirow[t]{2}{*}{$\mathrm{Cr}$} & Média & 69,0 & 45,7 & 24,5 & 77,4 & 52,7 & 38,9 & 72,1 & 50,2 & 30,8 \\
\hline & Desvio & 7,46 & 0,33 & 1.07 & 0,65 & 0,73 & 2,61 & 1,71 & 1,70 & 0,93 \\
\hline \multirow[t]{2}{*}{ Mn } & Média & 995 & 1005 & 1184 & 840 & 874 & 947 & 798 & 876 & 970 \\
\hline & Desvio & 130 & 36 & 6,0 & 53,1 & 13,0 & 45,7 & 17,9 & 5.9 & $\overline{22,6}$ \\
\hline \multirow[t]{2}{*}{$\mathrm{Ni}$} & Média & 36,2 & 19,3 & 7,53 & 37,4 & 19,0 & 7,98 & 40,1 & 22,3 & 7,53 \\
\hline & Desvio & 4,36 & 1,21 & 0,01 & 0,94 & 0,81 & 0,77 & 1,93 & 2,36 & 0,01 \\
\hline \multirow[t]{2}{*}{$\mathrm{Cu}$} & Média & 51,9 & 39,2 & 35,4 & 51,3 & 42,3 & 35,3 & 53,8 & 46,8 & 34,5 \\
\hline & Desvio & 3,66 & 0,99 & 5,90 & 1,27 & 0,68 & 4,44 & 0,85 & 0,86 & 0,28 \\
\hline \multirow[t]{2}{*}{$\mathrm{Zn}$} & Média & 138 & 105 & 55,3 & 174 & 92,1 & 56.7 & 182 & 110 & 47,8 \\
\hline & Desvio & 17,4 & 1,42 & 2,39 & 23,6 & 3,72 & 3,70 & 22,8 & 17,2 & 6,57 \\
\hline \multirow[t]{2}{*}{$\mathrm{Cd}$} & Média & 2,71 & 0,32 & 0,27 & 2,08 & 0,44 & 0,27 & 1,80 & 0,47 & 0,27 \\
\hline & Desvio & 0,31 & 0,05 & 0,01 & 0,28 & 0,04 & 0,01 & 0,15 & 0,09 & 0,01 \\
\hline \multirow[t]{2}{*}{$\mathbf{P b}$} & Média & 61,4 & 64,6 & 6.53 & 49,1 & 56,9 & 6,53 & 58,8 & 62,5 & 6,53 \\
\hline & Desvio & $\overline{19.2}$ & $0, \overline{19}$ & 0.01 & 3,10 & 2,36 & 0,01 & $\overline{11,2}$ & 1,10 & 0,01 \\
\hline
\end{tabular}

A utilização de sulfato de alumínio como coagulante, por exemplo, é preocupante quando estudos de caso para alguns metais têm atribuído ao alumínio uma importância crítica em doenças cardiovasculares, além de fortes suspeitas de que altas concentrações deste elemento estejam ligadas ao mal de Alzheimer (Redicdit, 1975). 
Avaliando-se os resultados apresentados na TAB.44, podemos observar que os principais elementos obtidos a partir da digestão total das amostras apresentaram níveis de concentração decrescendo na ordem $\mathrm{Al}>\mathrm{Na}>\mathrm{Fe}>\mathrm{K}>\mathrm{Mg}>\mathrm{Ca}>\mathrm{Mn}>\mathrm{P}>\mathrm{Ba}$. Por outro lado, a digestão parcial das amostras mostrou a seqüência $\mathrm{Al}>\mathrm{Fe}>\mathrm{Na}>\mathrm{Mg}>\mathrm{Ca}>\mathrm{K}>\mathrm{Mn}>\mathrm{P}>\mathrm{Ba}$, de forma que as diferenças observadas nas concentrações entre $\mathrm{Na}$ e Fe para as duas frações são provavelmente decorrentes da associação direta do sódio com estruturas de silicatos. A comparação destas frações com a seqüência obtida por extração dos metais lixiviáveis conforme $\mathrm{Al}>\mathrm{Fe}>\mathrm{Ca}>\mathrm{Mn}>\mathrm{P}>\mathrm{Mg}>\mathrm{Ba}$, apontaram o alumínio em amostras de lodo como um elemento com grande disponibilidade química.

Como a legislação ambiental brasileira ainda não prevê parâmetros para a qualidade de amostras de sedimentos (CONAMA, 2005), os resultados obtidos a partir dos três métodos de digestão propostos foram comparados aos valores de referência para avaliação de sedimentos estabelecidos pelo CCME (Canadian Council of Ministers of the Environment) como TEL (threshold effect level) e PEL (probable effect level), conforme apresentado na TAB.45. De acordo com CCME (1999), os parâmetros dados por limites de PEL representam níveis acima dos quais os metais presentes se encontram geralmente associados a efeitos adversos, enquanto os limites estabelecidos por TEL representam níveis abaixo dos quais efeitos biológicos adversos raramente podem representar algum dano significante aos organismos aquáticos presentes.

Nos estudos de digestão foram avaliados os elementos $\mathrm{Mn}, \mathrm{Ca}, \mathrm{Al}, \mathrm{Cu}, \mathrm{P}, \mathrm{Cr}, \mathrm{Zn}$, $\mathrm{V}, \mathrm{Ba}, \mathrm{Fe}, \mathrm{Ni}, \mathrm{Mg}, \mathrm{Cd}, \mathrm{Pb}, \mathrm{Co}, \mathrm{K}$ e $\mathrm{Na}$. Nas frações denominadas parcial e lixiviável verifica-se uma grande diferença de solubilização para determinados elementos. A avaliação dos resultados também foi realizada por meio da distribuição, em porcentagem, nas frações parciais e lixiviáveis em relação à concentração total de cada variável analisada, em função do periodo de coleta (TAB.46). Concentrações altas (> 80\% de lixiviação) foram observadas para as variáveis $\mathrm{Mn}, \mathrm{Ca}, \mathrm{Al}, \mathrm{Cu}, \mathrm{P}, \mathrm{Fe}, \mathrm{Mg}$ e o $\mathrm{Pb}$, quando foi utilizado o procedimento de solubilização com $\mathrm{HNO}_{3} / \mathrm{HCl}$.

$\mathrm{Na}$ fração lixiviável do lodo, somente $\mathrm{Mn}, \mathrm{Ca}$ e $\mathrm{Al}$ apresentaram lixiviação elevada, acima de $80 \%$. Alguns metais tóxicos, como $\mathrm{Ni}, \mathrm{Cd}, \mathrm{Pb}$ e $\mathrm{Co}$ foram detectados, mas em níveis de concentração inferiores a $100 \mathrm{mg} \cdot \mathrm{kg}^{=1}$. 
TABELA 45 - Intervalo de concentração e concentrações médias dos analitos (mg. $\left.\mathrm{kg}^{-1}\right) \mathrm{em}$ diferentes frações de 3 amostras de lodo seco.

\begin{tabular}{|c|c|c|c|c|c|c|}
\hline \multirow[t]{2}{*}{ PARÂMETRO } & \multicolumn{3}{|c|}{$\begin{array}{c}\text { Concentração } \\
\left(\mathrm{mg} \cdot \mathrm{kg}^{-1}\right)\end{array}$} & \multicolumn{3}{|c|}{$\begin{array}{c}\text { Intervalo de Concentração* } \\
\left.\text { (mg.kg }{ }^{*}\right)\end{array}$} \\
\hline & TEL & PEL & $\begin{array}{c}\text { Digestão } \\
\text { Total } \\
\text { (Média) }\end{array}$ & Digestão Total & Digestão Parcial & Lixiviável \\
\hline A) & . & 58.030 & 78.071 & $59.835-91310$ & $53.278-70.368$ & $51.550-85.833$ \\
\hline $\mathrm{Na}$ & - & - & 49.479 & $43.484-55.797$ & $2.717-5.259$ & $7.54-23.2$ \\
\hline $\mathrm{Fe}$ & - & - & 48.174 & $46.921-49.233$ & $41.956-46.662$ & $8.753-12.479$ \\
\hline $\mathbf{M g}$ & 460 & 1.100 & 2.661 & $2.002-3.570$ & $2.349-2.669$ & $368-537$ \\
\hline K & - & - & 9.847 & $8.502-11.359$ & $1.220-2.348$ & $133-163$ \\
\hline $\mathrm{Ca}$ & - & - & 1.496 & $1.599-2.101$ & $1.178-1.681$ & $1.854-2.780$ \\
\hline Mn & - & - & 878 & $797-995$ & $873-1005$ & $947-1.184$ \\
\hline $\mathbf{P}$ & - & - & 964 & $952-981$ & $785-839$ & $589-673$ \\
\hline $\mathbf{B a}$ & - & - & 611 & $428-802$ & $269-316$ & $120-153$ \\
\hline $\mathrm{Zn}$ & 123 & 315 & 165 & $137-181$ & $92-110$ & $47-57$ \\
\hline v & - & - & 115 & $109-120$ & $72-86$ & $24-42$ \\
\hline Co & 50,0 & - & 79.1 & $77,5-80,7$ & $60,7-66,3$ & $7,54-9,78$ \\
\hline $\mathrm{Cr}$ & - & - & 73,1 & $69,7-77,4$ & $45,7-52,7$ & $24,5-38,9$ \\
\hline $\mathrm{Pb}$ & 37,3 & 90,0 & 56.4 & $49,1-61,4$ & $56,9-64,6$ & $6,50-6,53$ \\
\hline $\mathrm{Cu}$ & 35,7 & 197 & 52.3 & $51,3-53,8$ & $39,2-46,8$ & $34,5-35,4$ \\
\hline $\mathrm{Ni}$ & 18,0 & 35,9 & 37.9 & $36,2-40,1$ & $19,0-22,3$ & $7,53-7,98$ \\
\hline $\mathrm{Cd}$ & 0.60 & 3,53 & 2.20 & $1,80-2,71$ & $0,32-0,47$ & $0,25-0,27$ \\
\hline
\end{tabular}

*Digestão Total: EPA $3052\left(\mathrm{HNO}_{3} / \mathrm{HF}\right)$

*Digestão Parcial: EPA $3051\left(\mathrm{HNO}_{3} / \mathrm{HCl}\right)$

*Lixiviação: $\mathrm{HCl} 0,1 \mathrm{~mol} \mathrm{~L}^{-1}$

TEL: níveis abaixo dos quais efeitos biológicos adversos raramente podem representar algum dano significante aos organismos aquáticos presentes.

PEL: representam niveis acima dos quais os metais presentes se encontram associados a efeitos adversos, onde número de amostras $=3$

Por outro lado, a média das concentrações obtidas para o alumínio em todas as frações foi encontrada acima dos limites de PEL (58.030 mg. $\mathrm{kg}^{-1}$ ), em todo o período de coleta. Elementos como $\mathrm{Na}$ e $\mathrm{K}$, no entanto, mostraram uma baixa taxa de lixiviação, estando elementos associados à matriz silicato. Quando comparada com a fração parcial, a fração lixiviável dos elementos sódio e potássio apresentou valores próximos de $0,4 \%$ e $15 \%$, respectivamente. 
TABELA 46 - Distribuição das frações parciais e lixiviáveis em relação à concentração total de cada elemento analisado, para cada mês de coleta.

\begin{tabular}{|c|c|c|c|c|c|c|c|c|}
\hline & \multicolumn{2}{|c|}{ Dez./2003 } & \multicolumn{2}{|c|}{$\operatorname{Jan} . / 2004$} & \multicolumn{2}{|c|}{ Fev./2004 } & \multicolumn{2}{|c|}{ Valor Médio } \\
\hline & $\begin{array}{c}\% \\
\text { Parcial }\end{array}$ & $\begin{array}{c}\% \\
\text { Lixiv. }\end{array}$ & $\begin{array}{c}\% \\
\text { Parcial }\end{array}$ & $\begin{array}{c}\% \\
\text { Lixiv. }\end{array}$ & $\begin{array}{c}\% \\
\text { Parcial }\end{array}$ & $\begin{array}{c}\% \\
\text { Lixiv. }\end{array}$ & $\begin{array}{c}\% \\
\text { Parcial }\end{array}$ & $\begin{array}{c}\% \\
\text { Lixiv. }\end{array}$ \\
\hline Mn & 101 & 109 & 104 & 103 & 101 & 102 & 102 & 105 \\
\hline $\mathrm{Ca}$ & 80,0 & 102 & 86,4 & 108 & 105 & 103 & 90,5 & 104 \\
\hline Al & 58,4 & 56,5 & 84,7 & 103 & 101 & 102 & 84,2 & 96,3 \\
\hline $\mathrm{Cu}$ & 75,5 & 68,3 & 82,5 & 68,9 & 87,0 & 64,2 & 81,6 & 67,1 \\
\hline $\mathbf{P}$ & 81,8 & 62,9 & 85,6 & 60,1 & 88,1 & 70,7 & 85,1 & 64,6 \\
\hline $\mathbf{C r}$ & 65,6 & 35,1 & 68,1 & 50,2 & 69,6 & 42,6 & 67,8 & 42,7 \\
\hline $\mathbf{Z n}$ & 76,3 & 40,2 & 52,9 & 32,5 & 60,9 & 26,3 & 63,4 & 33,0 \\
\hline $\mathbf{v}$ & 65,8 & 22,6 & 73,3 & 35,9 & 71,8 & 29,1 & 70,3 & 29,2 \\
\hline $\mathbf{B a}$ & 39,4 & 19,1 & 44,6 & 19,9 & 71,6 & 29,4 & 51,8 & 22,8 \\
\hline Fe & 89,4 & 18,7 & 91,3 & 25,4 & 96,5 & 20,0 & 92,4 & 21,3 \\
\hline $\mathbf{N i}$ & 53,3 & 20,8 & 50,7 & 21,3 & 55,5 & 18,8 & 53,2 & 20,3 \\
\hline $\mathbf{M g}$ & 74,8 & 15,0 & 97,5 & 15,4 & 124 & 18,4 & 98,9 & 16,3 \\
\hline Cd & 11,9 & 9,97 & 21,3 & 13,0 & 25.9 & 15,0 & 19,7 & 12,7 \\
\hline $\mathbf{P b}$ & 105 & 10,6 & 116 & 13,3 & 106 & 11,1 & 109 & 11,7 \\
\hline Co & 75,2 & 10,2 & 80,2 & 12,4 & 85,6 & 9,73 & 8,03 & 3,32 \\
\hline $\mathbf{K}$ & 10,7 & 1,17 & 17,6 & 1,68 & 27,6 & 1,57 & 18,7 & 1,48 \\
\hline $\mathbf{N a}$ & 4,87 & 0,03 & 6,14 & 0,05 & 12,1 & 0,02 & 7,70 & 0,03 \\
\hline
\end{tabular}

Avaliando-se individualmente cada elemento analisado, verifica-se que o magnésio extraível foi encontrado em uma grande proporção na fração parcial (mais de $75 \%$ da fração total), apesar da disponibilidade deste elemento por lixiviação representar somente $20 \%$ da porção parcial. Porém, as frações lixiviáveis de magnésio estiveram próximas com os limites de TEL (460 mg. $\mathrm{kg}^{-1}$ ). $\mathrm{O}$ ferro foi encontrado mais associado às frações parciais, com níveis de lixiviação representando de $21 \%$ a $27 \%$ da porção parcial. O manganês apareceu fracamente associado às fases total e parcial em razão de uma provável adsorção pelas partículas de lodo ou pela associação com matéria orgânica, apresentando um nível de lixiviação perto de $100 \%$ quando comparado com o teor total. Apesar de alguns problemas observados nas medidas de cálcio, a razão entre a fração total, parcial e lixiviável apontou este elemento como facilmente disponivel ao meio ambiente. 
De acordo com os resultados apresentados na TAB.47, o cobre representa o elemento mais facilmente extraivel quando se comparam os percentuais das frações parcial e lixiviável, em relação à concentração total. Os resultados para o cobre e cromo obtidos a partir da digestão parcial mostraram níveis de concentrações superiores aos limites de TEL (35 mg. $\mathrm{kg}^{-1}$ ). Ambos os elementos apresentaram níveis de disponibilidade por lixiviação também próximos aos limites de TEL.

TABELA 47 - Distribuição entre elementos-traços analisados em diferentes frações.

\begin{tabular}{ccc}
\hline Procedimento & $\begin{array}{c}\text { Proporção dos Níveis de } \\
\text { Concentração Encontrados } \\
\text { entre os Analitos }\end{array}$ & $\begin{array}{c}\text { Percentual das Frações } \\
\text { Analisadas, em Relação à Fração } \\
\text { Total. }\end{array}$ \\
\hline $\begin{array}{c}\text { Concentração } \\
\text { Total }\end{array}$ & $\mathrm{Zn}>\mathrm{V}>\mathrm{Co}>\mathrm{Cr}>\mathrm{Pb}>\mathrm{Cu}>\mathrm{Ni}>\mathrm{Cd}$ & - \\
\hline $\begin{array}{c}\text { Concentração } \\
\text { Parcial }\end{array}$ & $\mathrm{Zn}>\mathrm{V}>\mathrm{Co}>\mathrm{Pb}>\mathrm{Cr}>\mathrm{Cu}>\mathrm{Ni}>\mathrm{Cd}$ & $\mathrm{V} \sim \mathrm{Cr}(70 \%)>\mathrm{Zn}(60 \%)>\mathrm{Ni}(50 \%)$ \\
\hline $\begin{array}{c}\text { Concentração } \\
\text { do Lixiviável }\end{array}$ & $\mathrm{Zn}>\mathrm{Cu}>\mathrm{V}>\mathrm{Cr}>\mathrm{Co}>\mathrm{Ni}>\mathrm{Pb}>\mathrm{Cd}$ & $\mathrm{Cu}(70 \%)>\mathrm{Cr}(40 \%)>\mathrm{Zn} \sim \mathrm{V}(30 \%)$ \\
\hline
\end{tabular}

Apesar do zinco apresentar a maior disponibilidade dentre os outros elementos nesta fração, apresenta valores inferiores aos limites de TEL, representando entre $30 \%$ a $60 \%$ das frações parcial e total deste elemento. Cerca de $70 \%$ da concentração de vanádio obtido por digestão total relaciona-se à fração parcial. No entanto, apenas $30 \%$ do valor encontrado na fração parcial do vanádio se encontra na forma lixiviável.

As observações obtidas parạ o cádmio mostraram niveis de concentração em digestão total superiores ao valor relacionado por TEL $\left(0,60 \mathrm{mg} \cdot \mathrm{kg}^{-1}\right)$. O percentual obtido da digestão parcial e lixiviável deste elemento em relação ao teor total (cerca de 20 e 10\%, respectivamente), mostra que boa parte deste elemento deve estar associado à estruturas silicosas, sendo dificil sua disponibilidade para o ambiente. Deve-se atentar ao fato, no entanto, de que próximo de $50 \%$ do cádmio encontrado na porção parcial é facilmente lixiviável. 
O níquel apresentou níveis de concentração superiores aos limites estabelecidos por TEL (18,0 mg. $\left.\mathrm{kg}^{-1}\right)$ e PEL (35,9 mg. $\left.\mathrm{kg}^{-1}\right)$. Da mesma maneira que o cádmio, o níquel mostrou níveis de lixiviação abaixo dos limites de TEL e PEL, representando por cerca de $40 \%$ da fração parcial.

Os niveis de concentração totais obtidos para cobalto e chumbo encontram-se superiores aos limites de TEL e entre 80 e $90 \%$ destes teores correspondem ao encontrado nas frações parciais, também superiores a estes limites. No entanto, os níveis de lixiviação destes elementos correspondem entre 10 a $15 \%$ das frações parciais obtidas, respectivamente. $\mathrm{O}$ elemento fósforo apresenta um razoável potencial de disponibilidade, com níveis de $60 \%$ em relação à fração total e mais de $70 \%$ em relação à fração parcial.

Considerando-se as frações avaliadas para todos os elementos, verifica-se que os elementos $\mathrm{Al}, \mathrm{Ca}, \mathrm{Mn}, \mathrm{P}$ e $\mathrm{Cu}$ são facilmente extraíveis, demonstrando uma forte disponibilidade ao ambiente, principalmente quando se consideram níveis de lixiviação acima de $50 \%$ do teor total encontrado. Nas condições estudadas, a comparação da concentração média de disponibilidade por lixiviação de cada elemento com os limites de TEL, apontaram especificamente $\mathrm{Al}$ e $\mathrm{Cu}$ como os parâmetros mais importantes para a avaliação de contaminação de áreas próximas ao despejo de lodo por uma ETA.

Por outro lado, apesar da baixa disponibilidade identificada para alguns metais tóxicos presentes nas amostras de lodo, a interação destes metais em cursos d'água pode mudar em função de alterações físico-quimicas no ambiente. Tais mudanças, causadas por fontes antropogênicas, podem aumentar processos de lixiviação destes metais para águas superficiais (Salomons, 1995). Isto pode ser esperado para alguns elementos cujos niveis de disponibilidade por lixiviação representem pelo menos $50 \%$ do encontrado em digestões parciais das amostras de lodo, como os elementos $\mathrm{Zn}$, Ni e $\mathrm{Cr}$.

\subsection{Avaliação físico-química da água no sistema de tratamento e no descarte do lodo}

Na TAB.48 são mostrados os resultados quanto à caracterização das variáveis físicoquímicas da água ao longo de todo o processo de tratamento, desde a captação no rio 
Ribeira de Iguape até o final do descarte do lodo da ETA. Os resultados correspondem especialmente à ocorrência de metais solúveis na água na etapa do processo de despejo do lodo, em coletas de amostras de hora em hora na saída do cano de descarte do lodo do tanque de decantação, às margens do rio Sem Nome.

TABELA 48 - Variação da concentração (mg. $\mathrm{L}^{-1}$ ) dos metais dissolvidos ao longo do processo de tratamento, entre os meses de junho e julho de 2004.

\begin{tabular}{|c|c|c|c|c|c|c|c|c|c|c|c|c|c|c|}
\hline \multirow{3}{*}{$\begin{array}{l}\text { Variá } \\
\text { veis }\end{array}$} & \multicolumn{14}{|c|}{ Concentração (mg. $L^{-1}$ ) } \\
\hline & \multirow{2}{*}{$\begin{array}{l}\text { Ribeira } \\
\text { de } \\
\text { Iguape }\end{array}$} & \multirow[b]{2}{*}{ Captaçào } & \multirow[b]{2}{*}{ Flocul acāo } & \multirow[b]{2}{*}{ Decantusasio } & \multicolumn{10}{|c|}{ Efluente da ETA (Lavagem do Lodo do Decantador) } \\
\hline & & & & & Ih & $2 \mathrm{~h}$ & $3 \mathrm{~h}$ & $4 \mathrm{~h}$ & $5 \mathrm{~h}$ & $6 \mathrm{~h}$ & $7 \mathrm{~h}$ & $8 \mathrm{~h}$ & $9 \mathrm{~h}$ & $10 \mathrm{~h}$ \\
\hline $\mathrm{Na}$ & 2,4 & 2,4 & 2.5 & 2.5 & 3,3 & 3,8 & 3.4 & 2.4 & 2,2 & 2.2 & 2,1 & 2,1 & 3,4 & 2,1 \\
\hline $\mathbf{M g}$ & 3,4 & 3,4 & 3,5 & 3,6 & 7,8 & 8,5 & 5,9 & 2,2 & 2,5 & 2,4 & 2,3 & 2,0 & 2,6 & 2,5 \\
\hline K & 0,60 & 0.60 & 0.63 & 0,61 & 2,0 & 1,9 & 1,6 & 0.76 & 0,83 & 0,79 & 0,75 & 0,70 & 0,92 & 0,8 \\
\hline $\mathrm{Ca}$ & 8,5 & 8,7 & 8,9 & 9,9 & 15 & 16 & 12 & 3.5 & 4,0 & 3,6 & 3,4 & 3,0 & 3.8 & 3,5 \\
\hline $\mathrm{Fe}$ & 0,48 & 0,39 & 0,77 & 0,10 & 0,10 & 0.12 & 0.08 & 0.26 & 0.05 & 0,09 & 0,01 & 0,17 & 0,03 & 40.004 \\
\hline $\mathbf{B a}$ & 0,03 & 0,03 & 0,03 & 0,32 & 0,19 & 0,25 & 0,19 & 0,03 & 0,03 & 0,02 & 0,02 & 0,02 & 0,02 & 0,02 \\
\hline $\mathrm{Al}$ & 0,12 & 0,07 & 2,0 & 0,43 & 0,18 & 0,14 & 0,15 & 0,39 & 0,11 & 0,15 & 0,05 & 0,13 & 0,08 & 0,05 \\
\hline $\mathrm{Mn}$ & 0.04 & 0,03 & 0,03 & 0,01 & 9,9 & 16 & 3,6 & 0.72 & 0,67 & 0,36 & 0,22 & 0,12 & 0,24 & 0,09 \\
\hline
\end{tabular}

Na FIG.34 mostram-se os valores médios dos resultados obtidos nos vários pontos de monitoramento, em relação à concentração dos metais e elementos-traço na fração solúvel das amostras de água ao longo de todo o processo de tratamento e durante a etapa do processo de descarte, em um ciclo completo de limpeza do decantador.

Os resultados da qualidade da água no Rio Ribeira de Iguape após a ETA também estão apresentados. Nas FIG. 35 e 36 são mostrados os perfis da variação do $\mathrm{pH}$ e da turbidez no processo de descarte do lodo. Os resultados obtidos permitiram estabelecer um perfil da ETA de Registro conforme mostrado na FIG.34, evidenciando o comportamento de cada parâmetro analisado na fração solúvel das amostras coletadas ao longo do processo de tratamento de água. 


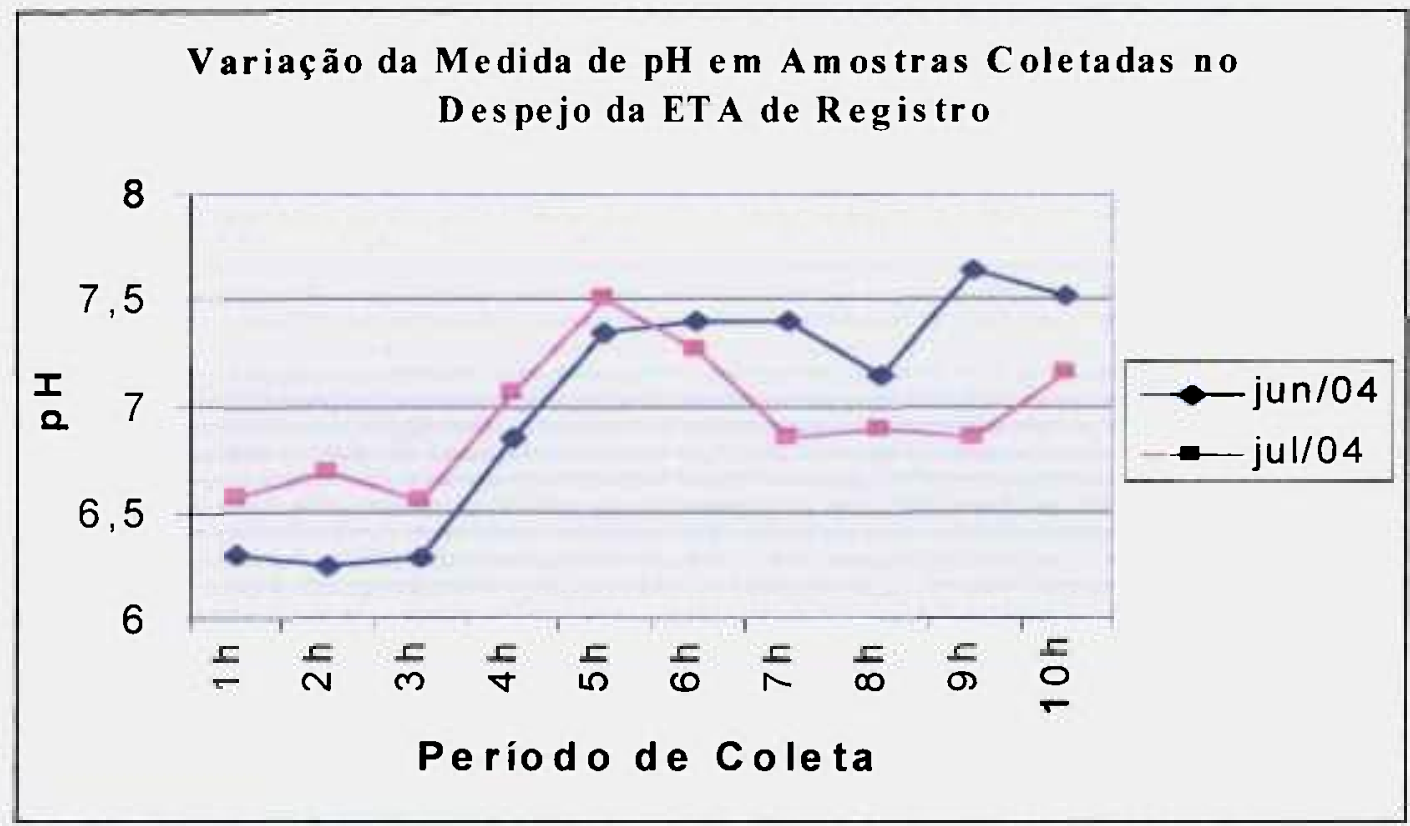

FIGURA 35 - Perfil do pH no processo de descarte do lodo do decantador e do filtro.

Um aumento na concentração desses elementos também foi observado no processo de limpeza dos filtros, a partir da $9^{\mathrm{a}}$ hora monitorada (FIG.34). A partir da quarta hora do início do despejo, os níveis de concentração para este grupo de elementos ficaram abaixo de $5 \mathrm{mg} \cdot \mathrm{L}^{-1}$.

Os elementos Fe $\left(15 \mathrm{mg} \cdot \mathrm{L}^{-1}\right)$ e $\mathrm{Ba}\left(5 \mathrm{mg} \cdot \mathrm{L}^{-1}\right)$, apresentaram níveis de concentração abaixo do valor máximo estabelecido pela Resolução CONAMA 357. O aumento da concentração de $\mathrm{Al}$ observada na etapa de floculação está relacionado à adição do sulfato de alumínio como coagulante. O decréscimo de concentração observado posteriormente sugere que a maior parte do elemento está associada à fração insolúvel.

O manganês esteve presente em baixas concentrações em todo o processo da ETA, porém, apresentou uma elevação na sua concentração durante o processo de limpeza do decantador, atingindo níveis de concentração muito acima do valor permitido para lançamento $\left(1,0 \mathrm{mg} \cdot \mathrm{L}^{-1}\right)$. A presença deste elemento pode estar associada à adição dos insumos utilizados no tratamento de água, ou mesmo à presença (apesar de em níveis traços) na água de captação na forma de complexos com compostos húmicos (Scalize, 2004), passando por processos de pré-concentração como os observados para Ca, $\mathrm{Mg}$ e $\mathrm{K}$. 


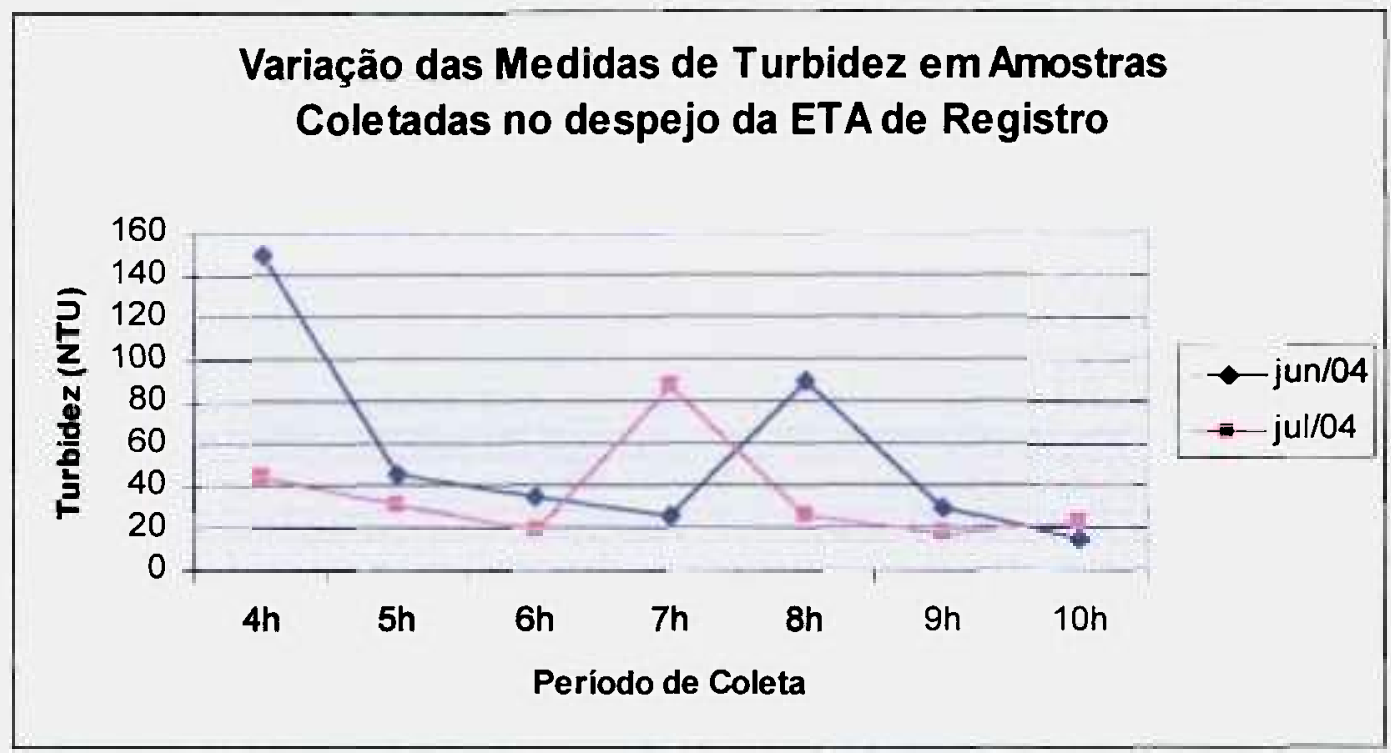

FIGURA 36 - Variação das medidas de turbidez do despejo da ETA, período junho e julho de 2004.

No caso específico do manganês, hidróxidos insolúveis em água são formados durante a etapa de correção de pH na ETA (da mesma forma que alguns metais como o ferro). Porém, condições anaeróbias ou do baixo $\mathrm{pH}$ encontradas no fundo dos tanques de decantação podem favorecer a dissolução dos sólidos depositados destes elementos, tornando-os presentes no lodo na forma de substâncias dissolvidas. Quando estes sólidos depositados no fundo dos decantadores são perturbados, como durante a lavagem dos decantadores ou quando o lodo de fundo dos tanques é descartado, estes elementos podem ser eliminados no descarte em concentrações maiores, encontrando-se na fração solúvel do despejo (Furrey, 2000). Deste modo, os altos teores de manganês verificados em até três horas a partir do início da operação, também inviabilizam o descarte do lodo in natura em cursos d'água. Em razão da alta concentração de manganês observada e da possibilidade de sua presença estar relacionada ao grande volume de sulfato de alumínio adicionado na ETA, a determinação de manganês foi efetuada nas amostras de coagulante utilizado na ETA.

Os resultados permitiram observar também que no processo de lavagem dos filtros (a partir de oito horas do início do despejo do lodo) ocorre um novo incremento nas concentrações de alguns elementos. No entanto, nesta etapa nenhum dos elementos analisados apresentou níveis de concentração acima dos valores permitidos pela legislação. 
De acordo com a FIG.35, o monitoramento do $\mathrm{pH}$ mostrou que o despejo da ETA apresentou uma variação pouco significativa, especialmente entre o início e o fim do processo de lançamento. O material descartado encontra-se dentro das condições de lançamento de efluentes para este parâmetro ( $\mathrm{pH}$ entre 5 e 9), conforme CONAMA 357, apesar do córrego receptor ter apresentado no momento anterior ao lançamento da ETA, um valor de $\mathrm{pH}$ próximo a 6,9 para ambos os meses. Medidas de $\mathrm{pH}$ em torno de 7 mostrando um meio relativamente neutro no despejo do lodo decorrem das condições de tratamento da própria ETA, onde metais traços são praticamente insolúveis nestas condições, facilitando sua separação (Barroso, 2002 apud AWWARF \& KIWA).

A FIG.36 mostra a avaliação da turbidez em razão da presença de materiais em suspensão até a $5^{\mathrm{a}}$ hora do início do despejo. No periodo até 3 horas foi observado um nível de turbidez acima de $1.000 \mathrm{NTU}$, comprovando o forte comprometimento para o corpo d'água do despejo da ETA, nesta fase inicial. Em razão dos valores de turbidez encontrados, pôde ser verificado que até a terceira hora após o início da lavagem do decantador ocorre o despejo da maior parte do lodo depositado na ETA. Somente após a $10^{\mathrm{a}}$ hora os níveis de turbidez do córrego receptor retornam para níveis naturais constatados por medição prévia de 25 e 23 NTU, respectivamente, para ambos os meses.

Apesar do corpo d'água receptor possuir uma vazão média estimada (para períodos de estiagem) em 44L.s - $^{-1}$ o que garante uma velocidade de circulação, é visível no local de despejo da ETA o assoreamento causado pelo descarte sistemático do lodo (FIG.37).
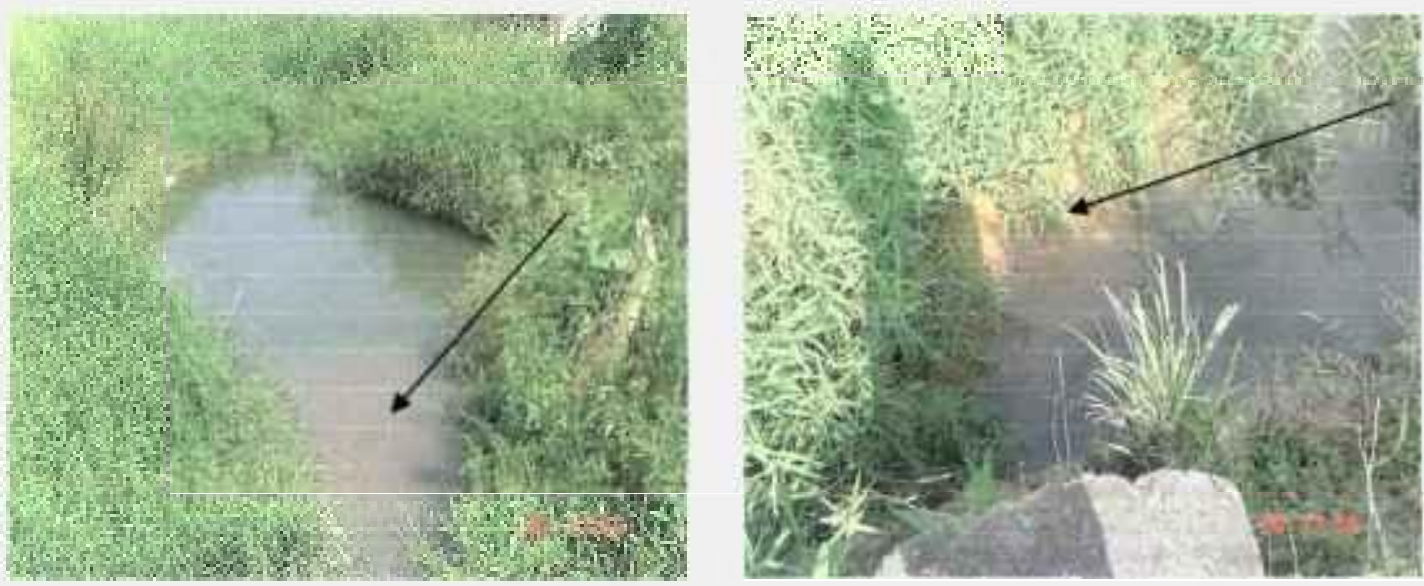

FIGURA 37 - Córrego da ETA, no período de estiagem (Agosto/2004). 
O depósito de lodo no corpo receptor pode ser facilmente diferenciado do sedimento do rio em função da tonalidade apresentada. Ainda que após 4 horas do início do despejo as medidas de turbidez encontrem-se abaixo de $160 \mathrm{NTU}$, percebe-se que neste local o curso d'água não dispersa o lançamento de efluentes da ETA. Considerando-se as medidas de manganês e de turbidez no início do despejo, pode-se admitir o período de até três horas do descarte como um período crítico para o lançamento dos efluentes da ETA.

\subsection{Tratamento matemático e estatístico dos dados utilizando gráficos ternários}

Com o objetivo de verificar a hipótese de que existe uma correlação dos parâmetros medidos na água durante o processo de tratamento, foram utilizados gráficos ternários. Os gráficos ternários constituem-se de uma comparação direta entre três componentes de um sistema, onde um dado ponto localizado em um dos vértices do triângulo indica que a concentração do componente correspondente àquele vértice será de $100 \%$ em relação aos outros dois componentes. Por outro lado, um dado ponto localizado exatamente no centro do triângulo mostra que o percentual relativo entre os três componentes é exatamente igual. Foram elaborados gráficos ternários correlacionando os elementos $\mathrm{Ca}, \mathrm{Mg}$ e $\mathrm{Mn}$ em diversas etapas do descarte do lodo da ETA. Nas FIG.38 e 39 apresentam-se a relação entre os elementos $\mathrm{Ca}, \mathrm{Mg}$ e $\mathrm{Mn}$, em amostras de descarte do lodo da ETA nos meses de junho e julho de 2004, respectivamente.

A relação entre os elementos $\mathrm{Ca}, \mathrm{Mg}$ e $\mathrm{Mn}$ demonstrou que a semelhança composicional observada entre os elementos $\mathrm{Ca}$ e $\mathrm{Mg}$ é decorrente desses elementos estarem associados quimicamente, preservando sua origem natural. A variação da proporção do manganês em relação ao $\mathrm{Ca}$ e ao $\mathrm{Mg}$ mostrou uma tendência no decréscimo nas concentrações de $\mathrm{Mn}$, indicando processos de eliminação do elemento no próprio despejo, conforme pode ser observado nos gráficos das FIG.38 e 39 e em função do deslocamento dos pontos para o eixo Ca - Mg. Uma avaliação dos dois gráficos permite concluir que ambos possuem tendências semelhantes, com a diminuição acentuada da presença de manganês nas amostras de despejo em um período de até 10 horas a partir do início do descarte. 


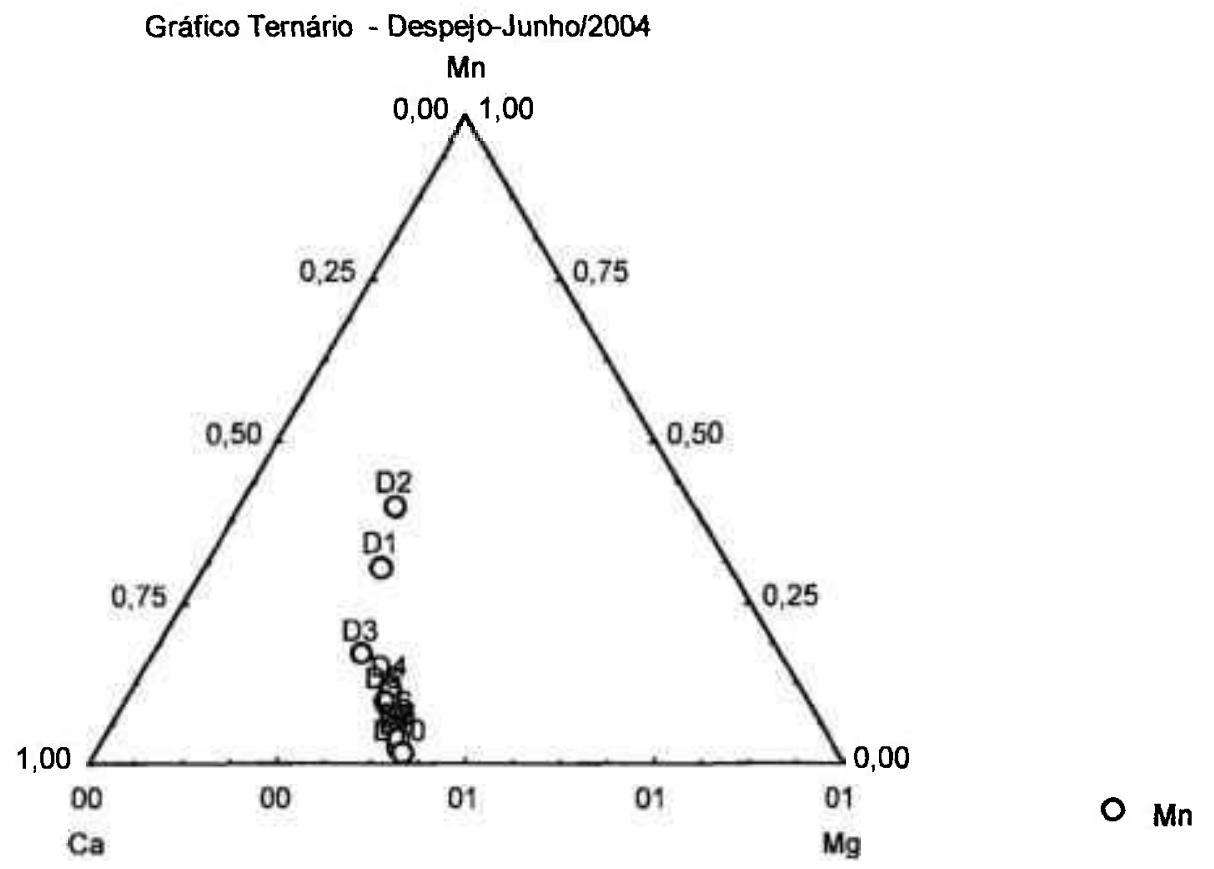

FIGURA 38 - Gráficos ternários correlacionando os elementos $\mathrm{Ca}, \mathrm{Mg}$ e $\mathrm{Mn}$ presentes na fração solúvel do despejo, nas primeiras 10 horas de descarte (D1 a D10) - Junho/2004.

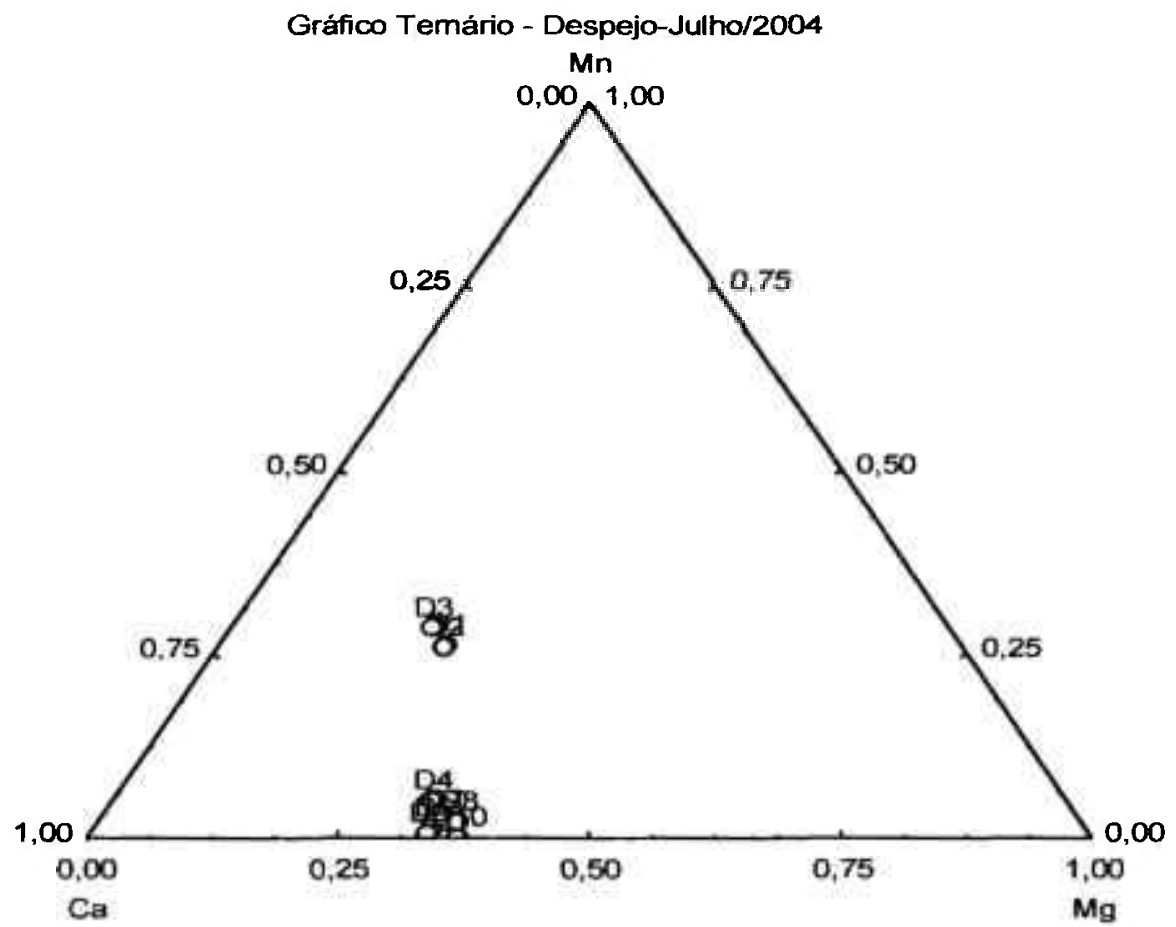

FIGURA 39 - Gráfico ternário correlacionando os elementos $\mathrm{Ca}, \mathrm{Mg}$ e $\mathrm{Mn}$ presentes na fração solúvel do despejo, nas primeiras 10 horas de descarte - Julho/2004. 
A diferença observada nas distribuições entre os três elementos, portanto, reforçam a idéia de que a presença do manganês no lançamento da ETA está relacionada à sua presença em alguns dos insumos adicionados pela própria ETA durante as operações de tratamento de água (TAB.36). O padrão de distribuição observado entre $\mathrm{Ca}$ e $\mathrm{Mg}$ ao longo de todo o período do despejo pode estar associado à grande presença de calcário na região do Ribeira de Iguape, principalmente porque esta relação também foi verificada na água de captação, no rio Ribeira de Iguape (FIG.40).

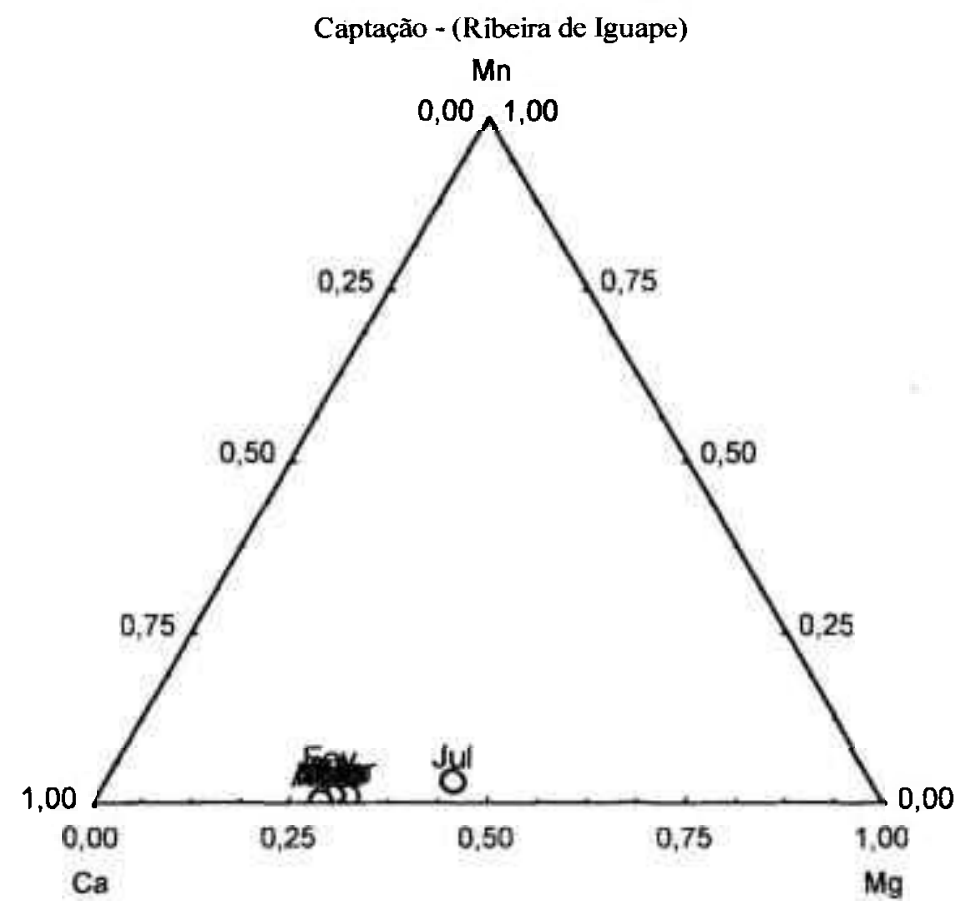

FIGURA 40 - Gráfico ternário correlacionando os elementos $\mathrm{Ca}, \mathrm{Mg}$ e $\mathrm{Mn}$ no rio Ribeira de Iguape (composição média no período de estudo), no ponto de captação da ETA, no período de Dezembro/2003 a Agosto/2004, para um total de nove amostras.

\subsection{Avaliação do impacto do despejo da ETA no curso d'água}

Na TAB. 49 apresentam-se os resultados obtidos do monitoramento da qualidade da água do corpo receptor, visando o acompanhamento do processo do descarte do lodo de ETA. O despejo do lodo foi avaliado por um periodo de 6 horas, iniciado em 1 hora após o inicio do descarte (T1) e demais cinco horas subseqüentes (T2; T3; T4; T5; T6) determinados no local do despejo, a 50 metros do descarte e a 300 metros do descarte. 
TABELA 49 - Caracterização do corpo receptor quanto à série de sólidos, pH e turbidez, durante o periodo até 6 h após o início do descarte do lodo.

\begin{tabular}{|c|c|c|c|c|c|c|c|}
\hline \multirow{2}{*}{$\begin{array}{c}\text { Pontos de } \\
\text { coleta }\end{array}$} & \multirow[t]{2}{*}{ Parâmetros } & \multicolumn{6}{|c|}{ Período de coleta (horas) } \\
\hline & & $\mathrm{T} 1$ & $\mathrm{~T} 2$ & $\mathrm{~T} 3$ & $\mathrm{~T} 4$ & T5 & T6 \\
\hline & Sólidos Totais $\left(\mathrm{mg} . \mathrm{L}^{-1}\right)$ & 12.066 & 3.868 & 1.548 & 190 & 92 & 128 \\
\hline Local do & Sólidos Fixos (mg. $\left.\mathrm{L}^{-1}\right)$ & 9.816 & 3.070 & 1.170 & 100 & 66 & 57 \\
\hline \multirow[t]{3}{*}{ Descarte } & Sólidos Voláteis (mg. $\left.L^{-1}\right)$ & 2.250 & 798 & 378 & 90 & 26 & 71 \\
\hline & Turbidez (NTU) & $>1.000$ & 85 & 18 & 41 & 23 & 14 \\
\hline & $\mathrm{pH}$ & 6,49 & 6,85 & 7,06 & 7,52 & 7,68 & 7,76 \\
\hline & Sólidos Totais (mg.L $\left.{ }^{-1}\right)$ & 2.594 & 636 & 507 & 304 & 216 & 242 \\
\hline & Sólidos Fixos (mg. $\left.\mathrm{L}^{-1}\right)$ & 1.908 & 458 & 334 & 180 & 188 & 197 \\
\hline \multirow[t]{5}{*}{$50 \mathrm{~m}$} & Sólidos Voláteis (mg. $\left.\mathrm{L}^{-1}\right)$ & 686 & 178 & 173 & 124 & 28 & 45 \\
\hline & Turbidez (NTU) & 140 & 79 & 85 & 53 & 46 & 45 \\
\hline & $\mathrm{pH}$ & 6,67 & 6,67 & 7,03 & 6,91 & 6,68 & 6,92 \\
\hline & Sólidos Totais (mg. $\left.\mathrm{L}^{-1}\right)$ & 118 & 118 & 94 & 108 & 84 & 123 \\
\hline & Sólidos Fixos (mg. $\left.\mathrm{L}^{-1}\right)$ & 84 & 80 & 31 & 50 & 56 & 60 \\
\hline \multirow[t]{3}{*}{$300 \mathrm{~m}$} & Sólidos Voláteis (mg.L $\left.\mathrm{L}^{-1}\right)$ & 34 & 38 & 63 & 58 & 29 & 63 \\
\hline & Turbidez (NTU) & 23 & 24 & 21 & 19 & 17 & 17 \\
\hline & $\mathrm{pH}$ & 6.67 & 6.64 & 6,58 & 6,60 & 6,64 & 6.72 \\
\hline
\end{tabular}

T1 a T6 - Período de coleta em horas, uma hora após o início do descarte.

Com exceção do $\mathrm{pH}$, todos os parâmetros considerados apresentaram valores mais elevados no local de descarte, comparando-se com as coletas realizadas a $50 \mathrm{~m}$ e a $300 \mathrm{~m}$ do local do despejo. Embora as medidas de turbidez representem um parâmetro importante para a avaliação do despejo, as medidas de sólidos totais realizadas fornecem um perfil mais exato da evolução do lodo no corpo d'água. Na FIG.41 é apresentada a variação da concentração de sólidos totais no efluente de despejo, a $50 \mathrm{~m}$ e a $300 \mathrm{~m}$ do descarte no córrego receptor, durante o período de descarte do lodo do decantador.

Verifica-se que, nas condições analisadas, o impacto do lodo no rio Sem Nome se dá por um período crítico de até quatro horas e a uma distância de no máximo de $50 \mathrm{~m}$ do local de despejo. Os resultados obtidos nas coletas realizadas a $300 \mathrm{~m}$ do lançamento da ETA não indicam qualquer indício de impacto do lodo, mostrando que o rio Sem Nome não apresenta risco de contaminação ao Rio Ribeira de Iguape. 


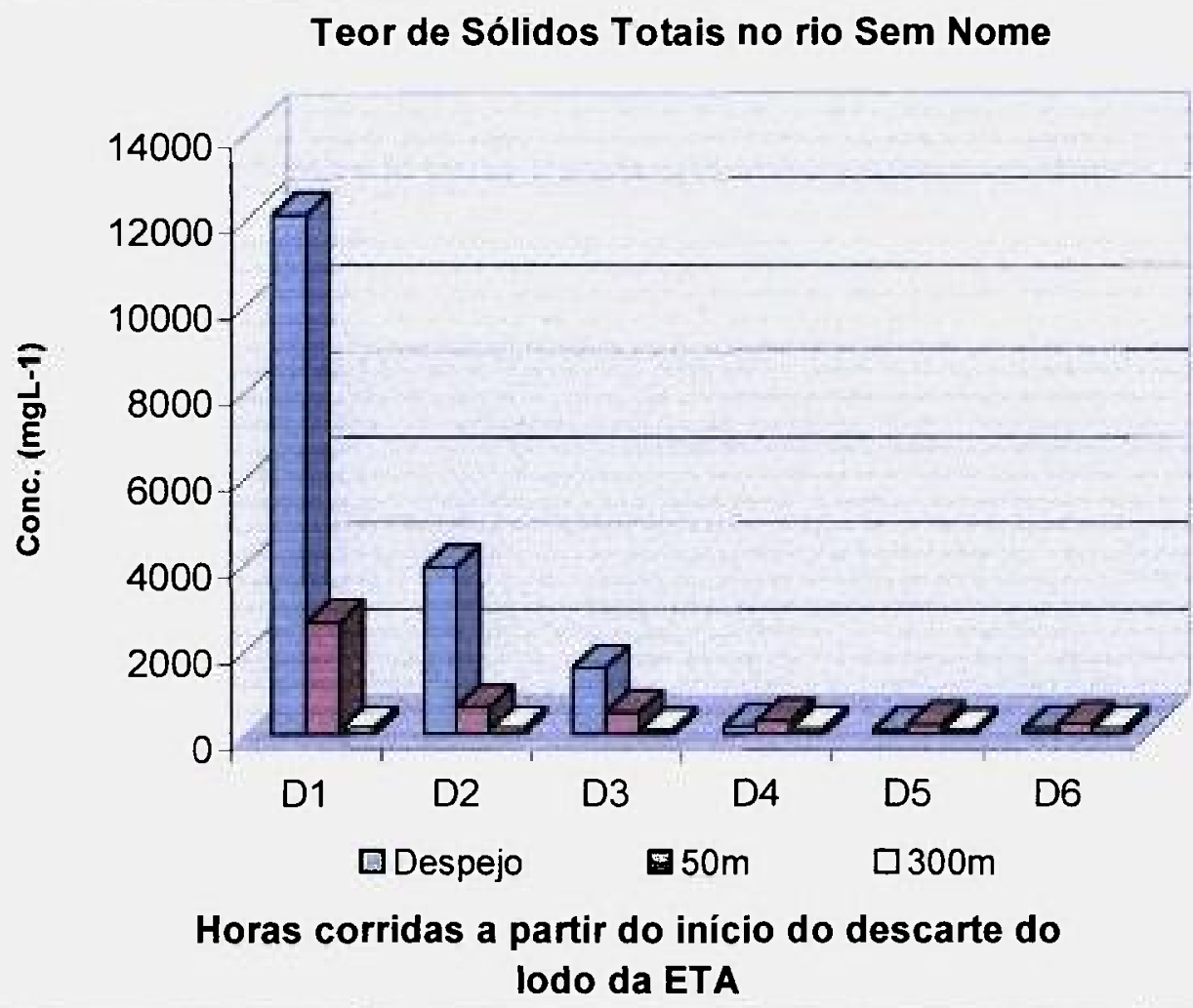

FIGURA 41 - Avaliação do teor de sólidos totais no córrego receptor até seis horas (DI a D6) do início do descarte da ETA.

$\mathrm{Na}$ TAB.50 são apresentados os resultados obtidos da caracterização do corpo receptor quanto a metais e elementos-traço durante o processo de descarte de lodo pela ETA. Pode ser observado que os valores a montante são relativamente maiores quando comparado com as características do corpo receptor. Porém, não alteram o ambiente de modo significativo. Os elementos $\mathrm{Co}, \mathrm{B}, \mathrm{V}, \mathrm{Cr}, \mathrm{Ni}, \mathrm{Cu}, \mathrm{Mo}, \mathrm{Ag}, \mathrm{Cd}$ e $\mathrm{Sn}$ também foram analisados, porém apresentaram níveis de concentração abaixo dos limites de determinação da metodologia aplicada.

Conforme mostrado na FIG. 42, medidas de $\mathrm{Na}, \mathrm{P}$ e $\mathrm{K}$ apresentam valores mais elevados nas medidas realizadas a $50 \mathrm{~m}$ do despejo. Não se observou nenhuma tendência dos valores resultantes deste ponto de coleta, para os outros coletados no local do próprio despejo e a $300 \mathrm{~m}$ do lançamento. 
TABELA 50 - Caracterização do corpo receptor quanto a metais e elementos-traço durante o processo de descarte de lodo pela ETA.

\begin{tabular}{|c|c|c|c|c|c|c|c|c|c|c|}
\hline \multirow{2}{*}{$\begin{array}{c}\text { Periodo } \\
\text { de } \\
\text { coleta } \\
\text { (Horas) } \\
\end{array}$} & \multirow{2}{*}{ Local coleta } & \multicolumn{9}{|c|}{ Concentração ( $\left.\mathrm{mg} . \mathrm{L}^{-1}\right)$} \\
\hline & & $\mathrm{Na}$ & $\mathrm{Mg}$ & $\mathbf{P}$ & $\mathrm{K}$ & $\mathrm{Ca}$ & $\mathrm{Fe}$ & $\mathrm{Ba}$ & $\mathrm{Al}$ & Mn \\
\hline & $\begin{array}{c}\text { Montante** } \\
\text { (Dia do descarte) }\end{array}$ & 26,35 & 4,4 & 1,25 & 3,35 & 15,2 & 4,00 & $0,04 \overline{9}$ & 0,12 & 0,11 \\
\hline & $\begin{array}{c}\text { Montante*** } \\
\text { (Media do Monitoramento) }\end{array}$ & 14,75 & 4,2 & 0,93 & 2,47 & 12,7 & 3,56 & 0,050 & 0,10 & 0,14 \\
\hline & & & & & & & & & & \\
\hline \multirow{3}{*}{$1 \mathrm{~h}$} & Despejo* & 3,14 & 3,0 & $<0,02$ & 0,84 & 5,30 & 0,03 & 0,056 & 0,077 & 2,37 \\
\hline & $50 \mathrm{~m}$ & 9,71 & 3,6 & $<0,02$ & 1,89 & 5,13 & 0,05 & 0,047 & 0,094 & 1,33 \\
\hline & $300 \mathrm{~m}$ & 6,45 & 2,5 & 0,36 & 0,96 & 2,82 & 2,07 & 0,022 & 0,244 & $<\mathrm{LQ}$ \\
\hline & & & & & & & & & & \\
\hline \multirow{3}{*}{$2 h$} & Despejo* & 2,70 & 2,4 & $<0,02$ & 0,77 & 3,98 & 0,13 & 0,031 & 0,266 & 0,93 \\
\hline & $50 \mathrm{~m}$ & 16,5 & 4,1 & 0,31 & 2,83 & 6,75 & 0,77 & 0,049 & 0,121 & 0,83 \\
\hline & $300 \mathrm{~m}$ & 7,36 & 2.7 & 0,51 & 1,11 & 3,11 & 2,37 & 0,027 & 0,199 & 0.08 \\
\hline \multirow{3}{*}{$3 \mathrm{~h}$} & Despejo* & 2,47 & 2,7 & $<0,02$ & 0,73 & 3,37 & 0,02 & 0,022 & 0,067 & 0,36 \\
\hline & $50 \mathrm{~m}$ & 2,90 & 3,0 & $<0,02$ & 0,76 & 3,68 & 0,03 & 0,020 & 0,071 & 0,17 \\
\hline & $300 \mathrm{~m}$ & 5,30 & 2,2 & 0,24 & 0.77 & 2.49 & 2,13 & 0,021 & 0,223 & $<\mathrm{LQ}$ \\
\hline \multirow{3}{*}{$4 \mathrm{~h}$} & Despejo* & 2,66 & 3,1 & $<0,02$ & 0,79 & 4,16 & 0,02 & 0,031 & 0,053 & 0,62 \\
\hline & $50 \mathrm{~m}$ & 19,6 & 4,3 & 1,87 & 3,02 & 6,88 & 3,59 & 0,042 & 0,301 & 0,12 \\
\hline & $300 \mathrm{~m}$ & 4,77 & 2,6 & 0,11 & 0,71 & 2,83 & 1,63 & 0,019 & 0,179 & $<\mathrm{LQ}$ \\
\hline & & & & & & & & & & \\
\hline \multirow{3}{*}{$5 \mathrm{~h}$} & Despejo* & 3,07 & 2,9 & $<0,02$ & 0.72 & 3,45 & 0,03 & 0,020 & 0,091 & 0,21 \\
\hline & $50 \mathrm{~m}$ & 20,4 & 4,3 & 1,70 & 3,08 & 7,19 & 3,14 & 0,042 & 0,203 & 0,24 \\
\hline & $300 \mathrm{~m}$ & 5,24 & 2,5 & 0,06 & 0,76 & 2,62 & 1,83 & 0,020 & 0,147 & $<\mathrm{LQ}$ \\
\hline \multirow{3}{*}{$6 \mathrm{~h}$} & Despejo* & 2,53 & 2,9 & $<0,02$ & 0,68 & 3,50 & 0,02 & 0.019 & 0,079 & 0,14 \\
\hline & $50 \mathrm{~m}$ & 21,7 & 4,3 & 1,69 & 3,25 & 7,04 & 3,00 & 0,037 & 0,236 & 0,17 \\
\hline & $300 \mathrm{~m}$ & 5,37 & 2,5 & 0.07 & 0,76 & 2.54 & 2,01 & 0,030 & 0,178 & 0,33 \\
\hline
\end{tabular}

*Local do despejo, no rio Sem Nome.

**Medidas realizadas ( $\mathrm{n}=1$ ) a montante do local despejo, em 1 dia após do descarte.

*** Média das medidas ( $n=9$ ) em todo o periodo (Dez./2003 a Ago./2004), em 1 dia após o descarte.

Em uma primeira avaliação, podem-se assumir estes valores de concentração para estes elementos como de natureza antrópica, sem nenhuma relação com o despejo da ETA. $\mathrm{A}$ análise de elementos como $\mathrm{Ca}, \mathrm{Mg}$ e $\mathrm{Ba}$ mostrou haver um background natural destes elementos, pela similaridade encontrada em todos os pontos de coleta a jusante do descarte, não demonstrando efeitos imediatos do despejo da ETA no corpo d'água receptor, para estes elementos. 
Na FIG.43 é mostrado que os teores de $\mathrm{Al}$ e Fe encontrados podem estar associados a fatores naturais e mesmo a influências antrópicas, sem demonstrar nenhuma tendência causada pelo descarte da ETA.
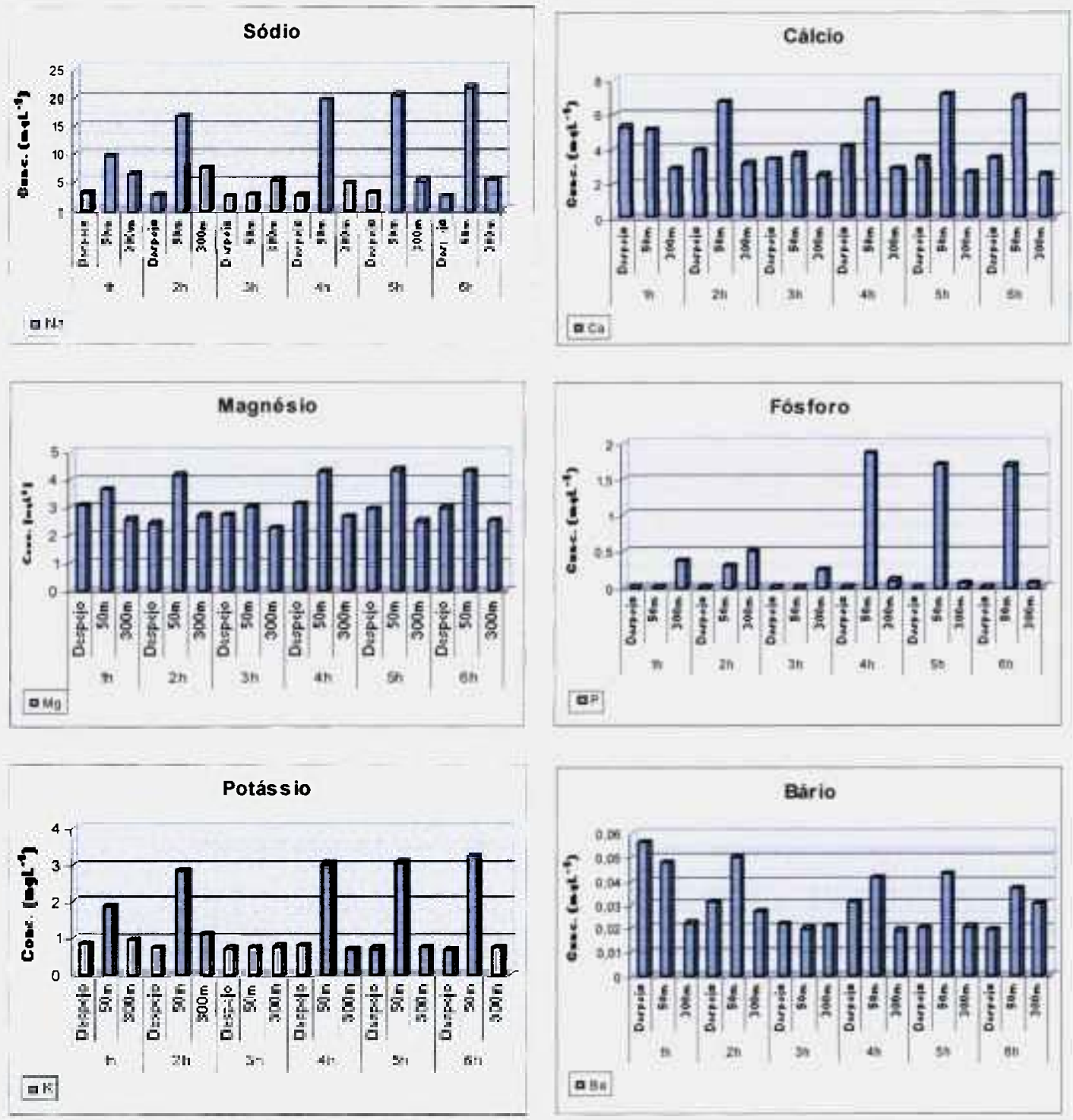

FIGURA 42 - Seqüência de gráficos resultantes da avaliação da propagação do despejo da ETA no curso d'água receptor, em razão da análise de elementos majoritários encontrados.

A análise de manganês, por outro lado, aponta para um decréscimo gradativo nos teores encontrados a partir do início do lançamento dos resíduos da ETA, de acordo com a FIG.44. Percebe-se que até a segunda hora do lançamento, o impacto ocorre em até $50 \mathrm{~m}$ do próprio local de despejo. 
A partir da terceira hora, porém, os níveis de manganês verificados a partir de $50 \mathrm{~m}$ tendem para um background natural. Até o início da quarta hora a partir do início do despejo ainda percebe-se um impacto do lodo no local de lançamento. Em relação às medidas de manganês encontradas, não se verifica impacto no rio Sem Nome a partir da quinta hora do início do despejo, mostrando que o processo de dispersão dos resíduos da ETA ocorre a partir deste período.
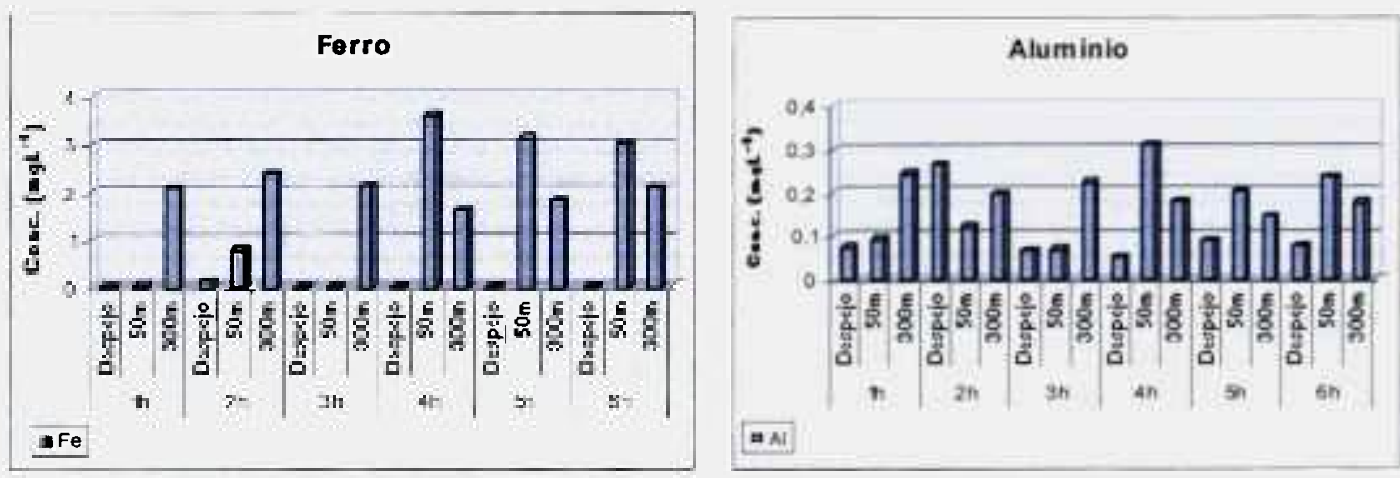

FIGURA 43 - Avaliação da propagação do despejo da ETA no curso d'água receptor, em função da análise dos elementos majoritários encontrados.

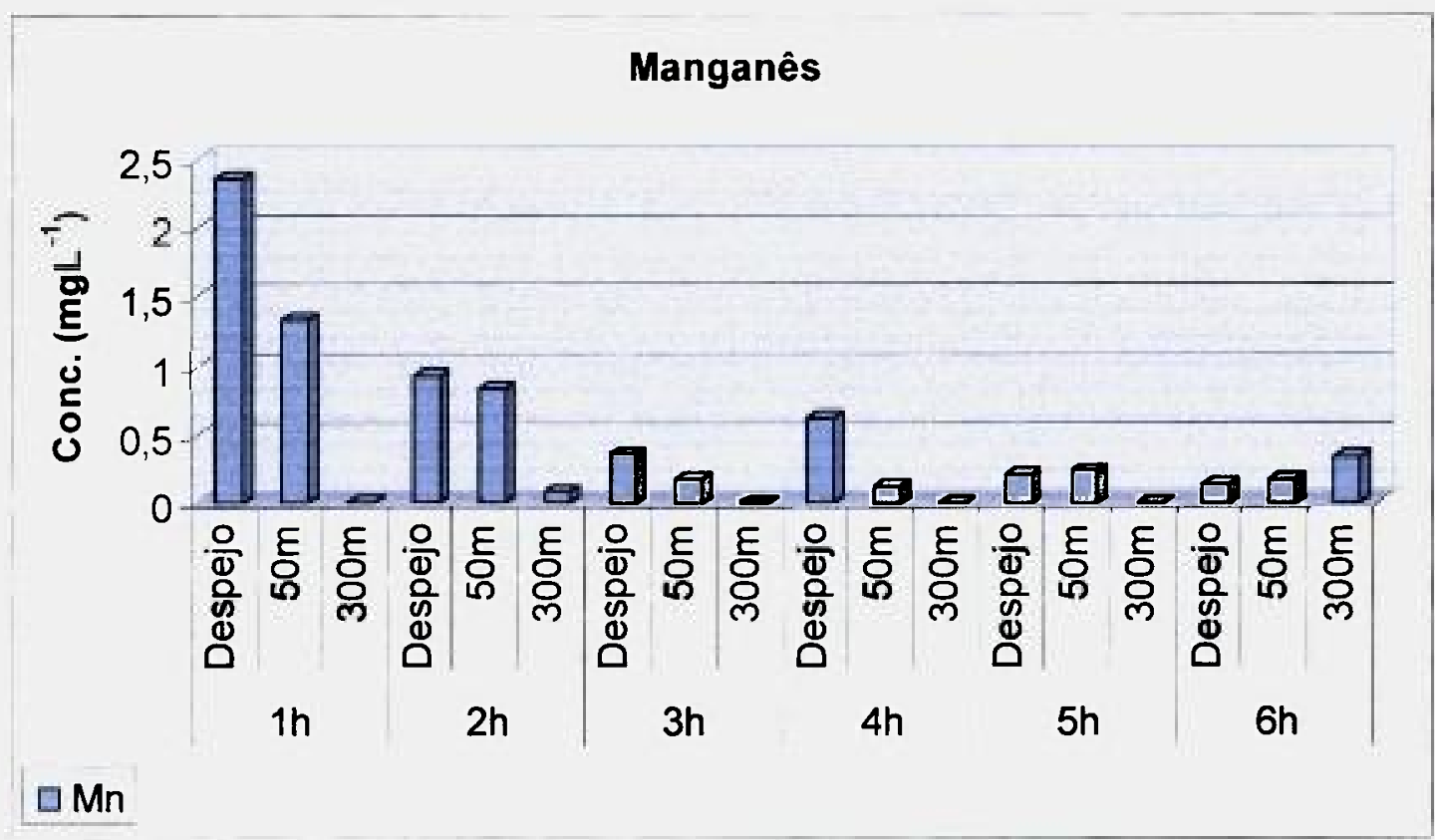

FIGURA 44 - Avaliação da propagação do despejo da ETA no curso d'água receptor, em razão da análise de manganês. 
A análise dos elementos encontrados em pontos de coleta a jusante do descarte da ETA mostraram que, nas condições estudadas, o Mn é o elemento que pode ser melhor utilizado como rastreador do descarte da ETA, especialmente por não ser comum à composição do solo ou sedimento da região.

\subsection{Análise das amostras de águas superficiais}

Na FIG.45 é mostrado um perfil das medidas de concentração de elementos majoritários presentes na fração solúvel de amostras de águas superficiais nos pontos de coleta P1, P2, P5 e P6, em 1 dia após o descarte de lodo pela ETA de Registro. As medidas correspondem as coletas mensais realizadas entre Dezembro de 2003 e Agosto de 2004.

Em uma primeira avaliação, verificou-se que foram encontrados níveis de concentração semelhantes entre os pontos de coleta $P 1$ e $P 2$, correspondentes a montante e jusante do Rio Sem Nome, respectivamente. A similaridade encontrada demonstra que, dentro dos parâmetros avaliados, não há evidência direta de impacto do despejo mensal da ETA no curso d'água receptor (Rio Sem Nome). O mesmo foi observado entre os pontos P5 e P6, correspondentes à montante e jusante da contribuição do Rio Sem Nome no Rio Ribeira de lguape, indicando uma rápida dispersão do efluente da ETA. A avaliação destes dois pontos de coleta demonstra que o despejo da ETA no curso d'água receptor (Rio Sem Nome) também não compromete diretamente a qualidade das águas superficiais do rio Ribeira de lguape. Por outro lado, a diferença nos níveis de concentração de $\mathrm{P}$ encontrados nos pontos de coleta no Rio Sem Nome (P1 e P2) e o Rio Ribeira de lguape (P5 e P6), evidencia também uma diferença na qualidade das águas dos rios estudados, em decorrência de descarga irregular de esgoto por todo o percurso do mesmo rio, conforme observado ao longo de todo o período de monitoramento.

Resultados obtidos nos pontos de coleta P3 e P4 não foram inclusos, pois avaliações preliminares mostraram que o Ribeirão de Registro não apresentou qualquer influência nos níveis de metais encontrados nos rios Sem Nome e Ribeira de Iguape. Na FIG.45 é mostrado, portanto, que medidas dos elementos $\mathrm{Na}, \mathrm{Ca}, \mathrm{Mg}, \mathrm{P}, \mathrm{Fe}$ e $\mathrm{K}$ não demonstraram impacto do descarte do lodo, especialmente quando se consideram os resultados obtidos em P2. 

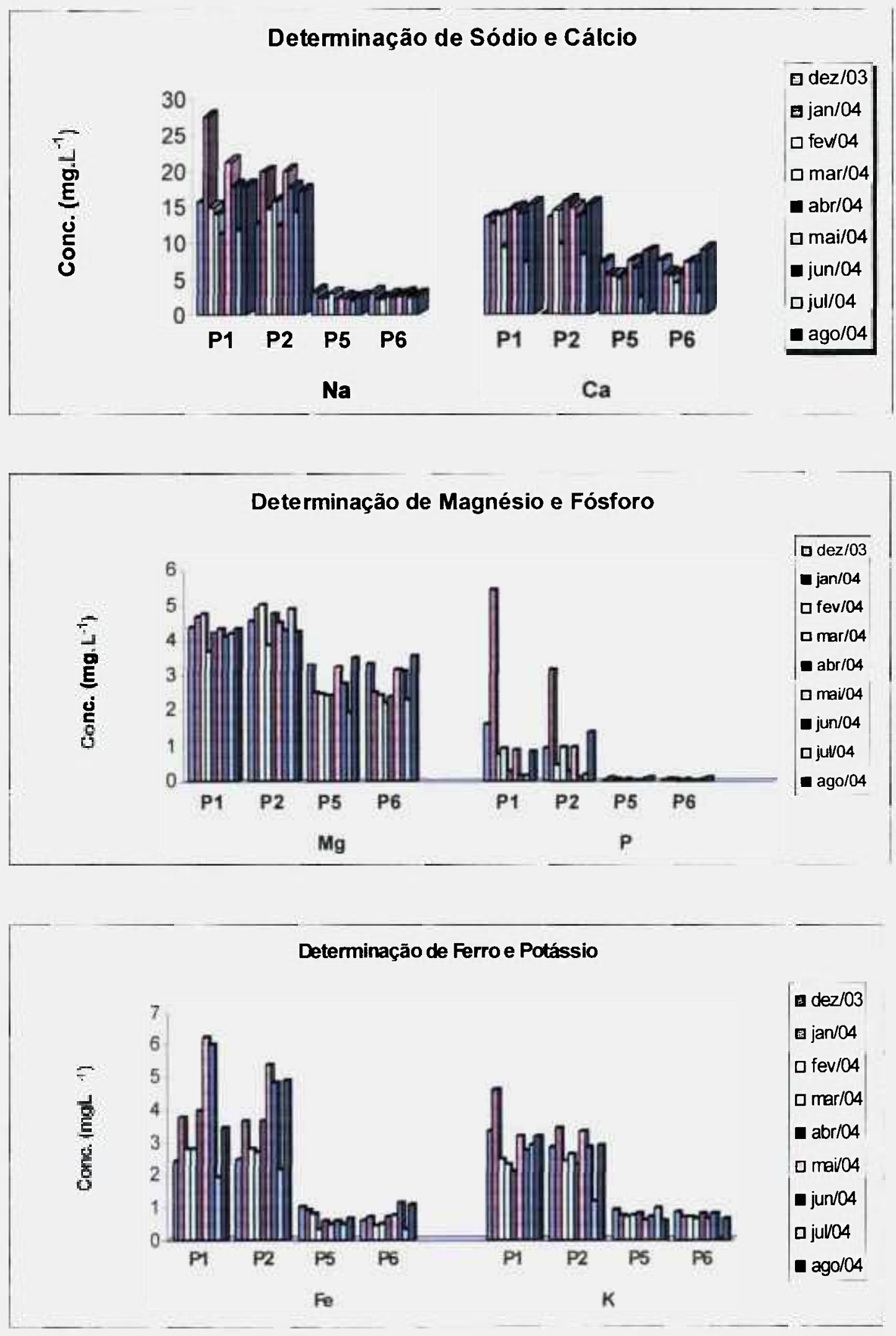

FIGURA 45 - Elementos majoritários em águas superficiais. 
Os resultados obtidos no entorno da ETA de Registro para as análises de Fe (FIG.46) reforçam este argumento, por mostrar niveis elevados de concentração em todos os pontos de coleta quando comparados aos níveis estabelecidos pelo CONAMA e não apenas nos pontos referentes à jusante do descarte, como seria esperado.

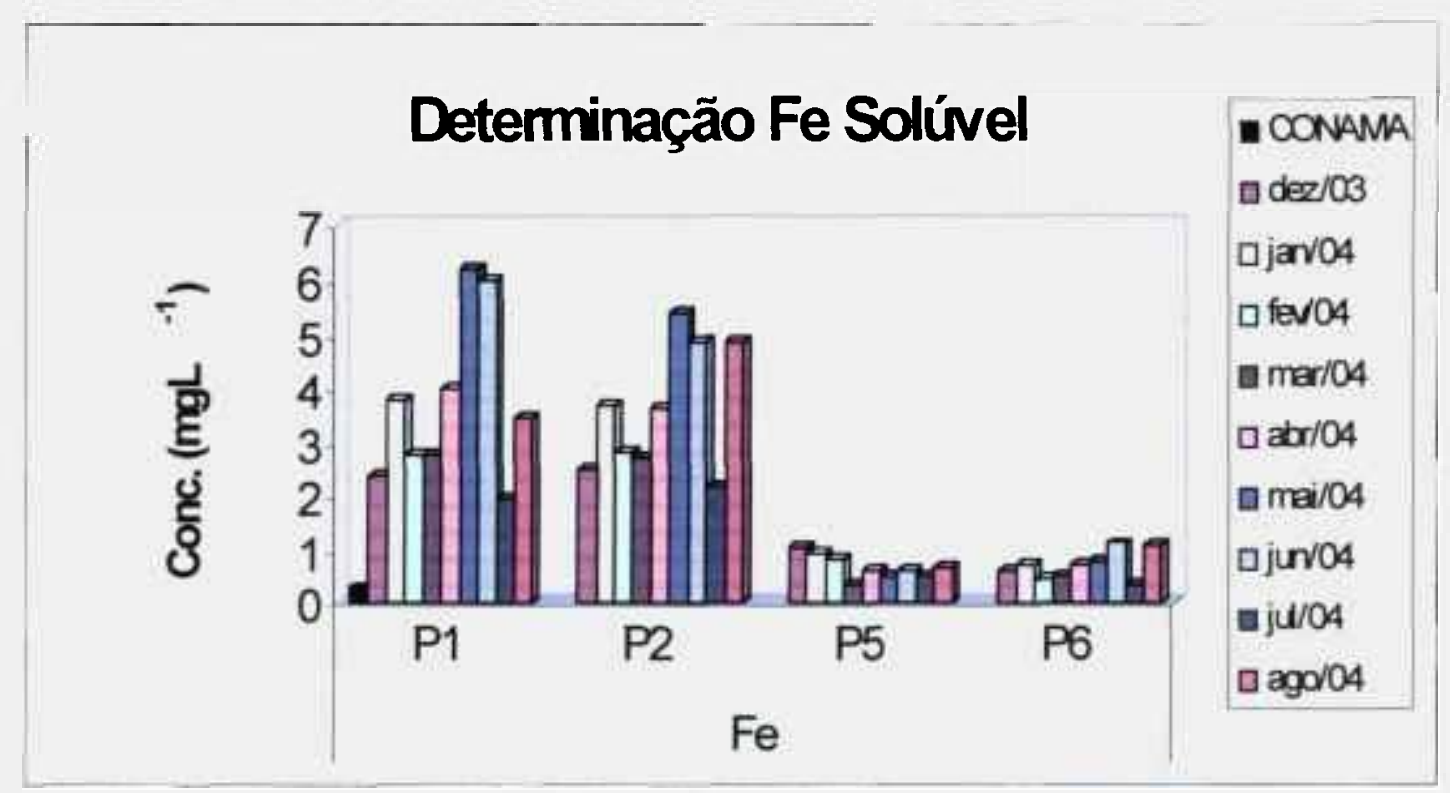

FIGURA 46 - Determinação de Fe solúvel em águas superficiais.

Na TAB.5I são mostrados os resultados obtidos para elementos em níveis de traços, obtidos em cada mês do período de monitoramento. Considerando-se os resultados obtidos no período para alguns metais tóxicos avaliados, verificou-se que elementos como $\mathrm{Al}, \mathrm{Mn}$, $\mathrm{Ni}, \mathrm{Zn}, \mathrm{Ag}$ e $\mathrm{Cd}$, foram detectados em algumas coletas em níveis acima dos limites estabelecidos pelo CONAMA.

Na TAB.51 também é mostrado que em cada local de coleta, os níveis encontrados para estes elementos não representam uma consequiência direta do descarte de lodo pela ETA, quando se compara as medidas realizadas à montante e jusante do descarte.

A comparação dos dados obtidos para os elementos $\mathrm{Ba}, \mathrm{Mn}$ e $\mathrm{Zn}$, mostrada na FIG. 47 reforça este argumento. As medidas efetuadas nos locais de coleta P5 e P6 mostram também que não há impacto do desaguamento do rio Sem Nome com o rio Ribeira de Iguape. 
TABELA 51 - Concentrações de metais em niveis de traços na fração solúvel de amostras de águas superficiais nos pontos de coleta, obtidos em cada mês do período de monitoramento, em 1 dia após o descarte.

\begin{tabular}{|c|c|c|c|c|c|c|c|c|c|c|c|}
\hline & \multicolumn{10}{|c|}{ Concentração (mg. $\left.\mathrm{L}^{-1}\right)$} \\
\hline & & $\begin{array}{c}\text { CONAMA } \\
357\end{array}$ & Dez. $/ 03$ & $\operatorname{Jan} . / 04$ & Fev./04 & Mar./04 & Abr. $/ 04$ & Mai./04 & Jun./04 & Jul./04 & Ago. $/ 04$ \\
\hline \multirow{4}{*}{$\mathbf{B a}$} & PI & \multirow{4}{*}{0,7} & 0.057 & 0,044 & 0,048 & 0,058 & 0,047 & 0.051 & 0,047 & 0.036 & 0.0520 \\
\hline & $\mathrm{P2}$ & & 0.056 & 0,047 & 0,052 & 0,059 & 0,052 & 0,056 & 0.051 & 0,040 & 0.050 \\
\hline & PS & & 0,046 & 0,037 & 0,037 & 0,041 & 0,037 & 0.026 & 0.035 & 0,030 & 0.032 \\
\hline & P6 & & 0.043 & 0.040 & 0.035 & 0,033 & 0,034 & 0,029 & 0.042 & 0,018 & 0.043 \\
\hline \multirow{4}{*}{ Co } & $\mathrm{PI}$ & \multirow{4}{*}{0,05} & $4 Q$ & 0,010 & 0,006 & 40 & 0,012 & $<\mathbf{Q Q}$ & 40 & 0,013 & 40 \\
\hline & $P 2$ & & $\angle Q$ & 0,008 & 0,005 & $4 Q$ & 0.014 & $<Q$ & $<\mathrm{LQ}$ & 0.013 & $\triangle Q$ \\
\hline & PS & & $<Q$ & 0.009 & 0,004 & $<Q$ & 0.011 & $<Q$ & $4 Q$ & 0,013 & $\mathcal{L Q}$ \\
\hline & P6 & & $4 Q$ & 0,008 & 0,007 & $\angle Q$ & 0.011 & $<\mathrm{LQ}$ & 40 & 0,013 & 20 \\
\hline \multirow{4}{*}{ B } & $\mathrm{Pl}$ & \multirow{4}{*}{0,5} & 0,014 & $4 Q$ & LQ & $\mathrm{LQ}$ & 0,013 & 0,023 & 0,022 & 0.015 & 0.007 \\
\hline & P2 & & 0,011 & 40 & 40 & $\Psi Q$ & 0,013 & 0,022 & 0,019 & 0,020 & 0,032 \\
\hline & P5 & & $\angle Q$ & $4 Q$ & 40 & $2 Q$ & 0,003 & 0,006 & 0,002 & 0,012 & 0,0152 \\
\hline & P6 & & $<\mathrm{LO}$ & 40 & $\triangle 0$ & $<L$ & 0.003 & 0,006 & 0,002 & 0,014 & 0.0175 \\
\hline \multirow{4}{*}{ Al } & Pl & \multirow{4}{*}{0,1} & 0,106 & 0,174 & 0.017 & 0,053 & 0.050 & 0,081 & 0,055 & 0.168 & 0,170 \\
\hline & $\mathrm{P} 2$ & & 0.147 & 0.129 & 0.028 & 0.183 & 0,080 & 0,103 & 0,307 & 0,198 & 0.250 \\
\hline & P5 & & 0,124 & 0,404 & 0,037 & 0,185 & 0.196 & 0,067 & 0.157 & 0.224 & 0.169 \\
\hline & Pr & & 0,108 & 0.158 & 0,045 & 0.123 & 0,163 & 0.108 & 0.147 & 0,185 & 0.173 \\
\hline \multirow{4}{*}{ V } & $\mathbf{P 1}_{1}$ & \multirow{4}{*}{0,1} & $4 Q$ & 40 & $<Q$ & $<Q$ & $2 Q$ & $\angle L Q$ & $\angle L Q$ & $\triangle Q$ & 0,011 \\
\hline & $P_{2}$ & & $\angle Q$ & $<Q$ & $<Q$ & $\angle Q$ & $\mathcal{L Q}$ & $\angle Q$ & $\angle Q$ & 0,008 & 0,012 \\
\hline & PS & & $\$ 0$ & $4 Q$ & $\triangle 0$ & $4 Q$ & 40 & $\angle \mathrm{Q}$, & $L Q$ & 0,017 & Q,015 \\
\hline & $\overline{P B}$ & & $\mathrm{LQ}$ & DQ & $\angle L Q$ & $\angle Q$ & LLQ & $<L Q$ & 20 & 0.018 & 0.0161 \\
\hline \multirow{4}{*}{$\mathrm{Cr}$} & $\mathrm{P} 1$ & & 0,007 & 40 & 40 & 0,027 & 0.027 & 0,032 & 0,009 & $\angle D$ & 0,009 \\
\hline & P2 & 005 & 0.010 & $\mathbf{L Q}$ & 0,004 & 0,028 & 0,029 & 0,030 & 0,005 & $\angle \mathrm{LO}$ & 0.011 \\
\hline & PS & 0,03 & 0,012 & $\Delta Q$ & 0.011 & 0,031 & 0,033 & 0,033 & 0,006 & 0,008 & 0,012 \\
\hline & $P B$ & & 0.009 & $<Q$ & 0.012 & 0,031 & 0,041 & 0.031 & 0.006 & 0.010 & 0.0124 \\
\hline & $\mathrm{PI}$ & & 0,118 & 0,101 & 0.143 & 0,146 & 0,171 & 0,126 & 0,138 & 0,161 & 0.140 \\
\hline $\mathrm{Mn}$ & $\mathrm{P2}$ & 0.1 & 0,223 & 0,090 & 0,156 & 0,147 & 0.182 & 0,127 & 0,149 & 0,210 & 0,154 \\
\hline & PS & & 0.107 & 0,058 & 0,108 & 0,102 & 0,097 & 0,040 & 0,076 & $0.0 n$ & 0,062 \\
\hline & PG & & 0,070 & 0,082 & 0.059 & 0,085 & 0,078 & 0,094 & 0.252 & 0,042 & 0.408 \\
\hline & $\mathrm{Pl}$ & & 40 & $\triangle 0$ & 0,003 & 40 & 0.002 & $4 Q$ & $<L Q$ & 0,004 & 0.003 \\
\hline $\mathrm{Ni}$ & $\mathrm{P2}$ & 0.025 & $4 Q$ & $4 Q$ & 0,003 & $<\mathrm{LQ}$ & 0,002 & $<\mathbf{L Q}$ & $4 Q$ & 0.007 & 0.023 \\
\hline & PS & 0,025 & $<Q$ & LQ & 0,005 & $\angle Q$ & 0,002 & $\angle Q$ & $\angle L Q$ & 0.017 & 0.029 \\
\hline & $f \gamma$ & & $\angle Q$ & 20 & 0,004 & $<L Q$ & 0,002 & $<Q$ & 40 & 0,019 & 0.030 \\
\hline & $\mathrm{P1}$ & & $\angle Q$ & $\angle Q$ & $\angle Q$ & $\angle \mathrm{LQ}$ & $4 Q$ & $\overline{L Q}$ & 40 & 0,004 & $4 Q$ \\
\hline $\mathrm{Cu}$ & $\mathrm{P} 2$ & 0000 & $\angle Q$ & $4 Q$ & 40 & $<\mathrm{LQ}$ & 40 & $\mathbb{L Q}$ & $\mathbf{L Q}$ & 0,005 & 0,0003 \\
\hline & PS & 0,009 & $\angle Q$ & $<\mathrm{LQ}$ & <LQ & LQ & LQ & $\triangle Q$ & $\angle \mathrm{LQ}$ & 0.015 & 0.003 \\
\hline & 86 & & $\triangle Q$ & $\$ 0$ & $<0$ & 40 & $\angle 0$ & $\angle Q$ & $<0$ & 0.016 & 0,005 \\
\hline & $\mathrm{PI}$ & & 0,078 & 0,087 & 0.328 & 0.007 & 0,014 & 0.010 & $\angle \mathrm{LQ}$ & 0.023 & 0,099 \\
\hline $\mathrm{Zn}$ & $\mathrm{P2}$ & 0,18 & 0.025 & 0.085 & 0.193 & 0.009 & 0.005 & 0.006 & $<L Q$ & 0.016 & 0.074 \\
\hline & Ps & & 0.059 & 0,103 & 0.018 & 0.007 & 0,006 & 0,003 & $<\mathrm{LQ}$ & 0.027 & 0,036 \\
\hline & 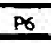 & & 0,038 & 0,083 & 0,045 & 0.010 & 0.005 & 0,000 & $\angle Q$ & 0.033 & 0.016 \\
\hline & P1 & & 0,002 & LQ & 0,012 & LO & 40 & $4 \mathrm{LQ}$ & $\angle Q$ & $<\mathrm{QQ}$ & 0,019 \\
\hline Mo & $\mathrm{P} 2$ & & $\angle Q$ & ¿LQ & 0,008 & $1 \mathrm{Q}$ & LQ & 0,003 & $\angle Q$ & $\approx \mathrm{LO}$ & 0,022 \\
\hline Mo & P5 & - & $<L Q$ & $\triangle Q$ & 0.006 & $<\mathrm{Q}$ & $\triangle Q$ & 0,001 & IQ & 0.006 & $a, 000$ \\
\hline & 86 & & $\mathrm{LO}$ & KLQ & 0,006 & $<Q$ & $\triangle Q$ & $\leq 0$ & $<0$ & 0.008 & 0,020 \\
\hline & $\mathrm{PI}$ & & 0,005 & LQ & 0.008 & $\mathrm{LQ}$ & $\angle Q$ & $4 Q$ & $\angle Q Q$ & $\mathrm{LQ}$ & 0,011 \\
\hline Ag & $\mathrm{P2}$ & 0.01 & $\angle Q$ & $\triangle Q$ & 0,002 & $\mathbf{L Q}$ & $\angle Q$ & $\angle Q$ & $\triangle Q$ & $<\mathrm{LQ}$ & 0.012 \\
\hline $\mathrm{Ag}$ & P5 & 0,01 & $\triangle Q$ & 40 & 0.047 & 40 & LQ & 40 & LQ & 0.006 & 0.015 \\
\hline & $P_{6}$ & & $<Q$ & 40 & 0.049 & $<\mathbf{L O}$ & $<L Q$ & $<\mathrm{LO}$ & $\angle Q$ & 0.009 & 0.016 \\
\hline & $\mathrm{Pl}$ & & $\angle L Q$ & $\mathbf{L Q}$ & 0,001 & LQ & 0,001 & 0,002 & $\angle \mathrm{LQ}$ & $\angle Q$ & 0,009 \\
\hline $\mathrm{Cd}$ & $\mathrm{P} 2$ & 0.001 & $<\mathbf{Q Q}$ & $4 Q$ & 0,002 & $4 Q$ & 0,001 & 0,002 & 40 & 40 & 0,010 \\
\hline -u & PS & 0,001 & $<\mathbf{Q Q}$ & 40 & 0,002 & LQ & 0,001 & 0,000 & $\angle Q$ & 0,004 & 0,010 \\
\hline & P6 & & $\angle Q$ & $\mathrm{LQ}$ & 0,002 & $<0$ & 0.001 & 0.001 & $\angle Q$ & 0,005 & 0.011 \\
\hline & $\mathrm{Pl}$ & & $\overline{L Q}$ & $4 Q$ & 0,017 & $\triangle Q$ & $\angle Q$ & 0,006 & $\angle \mathrm{LQ}$ & 10 & 40 \\
\hline Sn & P2 & - & $4 Q$ & $4 Q$ & 0,08 & 40 & 0,000 & 0,010 & $4 Q$ & $\triangle Q$ & 2Q \\
\hline Sn & P5 & $=$ & 20 & $\mathbb{L Q}$ & 0,024 & $<\mathrm{LQ}$ & 0,017 & 0,011 & 40 & $\angle Q$ & 40 \\
\hline & Po & & $<\mathrm{LQ}$ & $\angle \mathrm{L}$ & 0,020 & $<\mathrm{LQ}$ & 0.014 & 0.010 & $\angle Q$ & $\therefore \mathrm{LQ}$ & LQ \\
\hline & $\mathrm{PI}$ & & 0.001 & 0.002 & $ه 0,001$ & 0,001 & 0.001 & 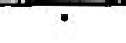 & 40,001 & 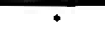 & $\cdot$ \\
\hline $\mathrm{b}$ & $p_{2}$ & 001 & 0,002 & $-0,001$ & 0.001 & -0.001 & $-0,001$ & - & 0,001 & - & - \\
\hline 0 & P5 & 0,01 & 0.003 & 0.003 & 0,004 & 0,004 & 0,004 & - & $<0,001$ & - & - \\
\hline & P6 & & 0.002 & 0.004 & 0.003 & 0.002 & 0.003 & - & $\infty 0,001$ & . & . \\
\hline
\end{tabular}




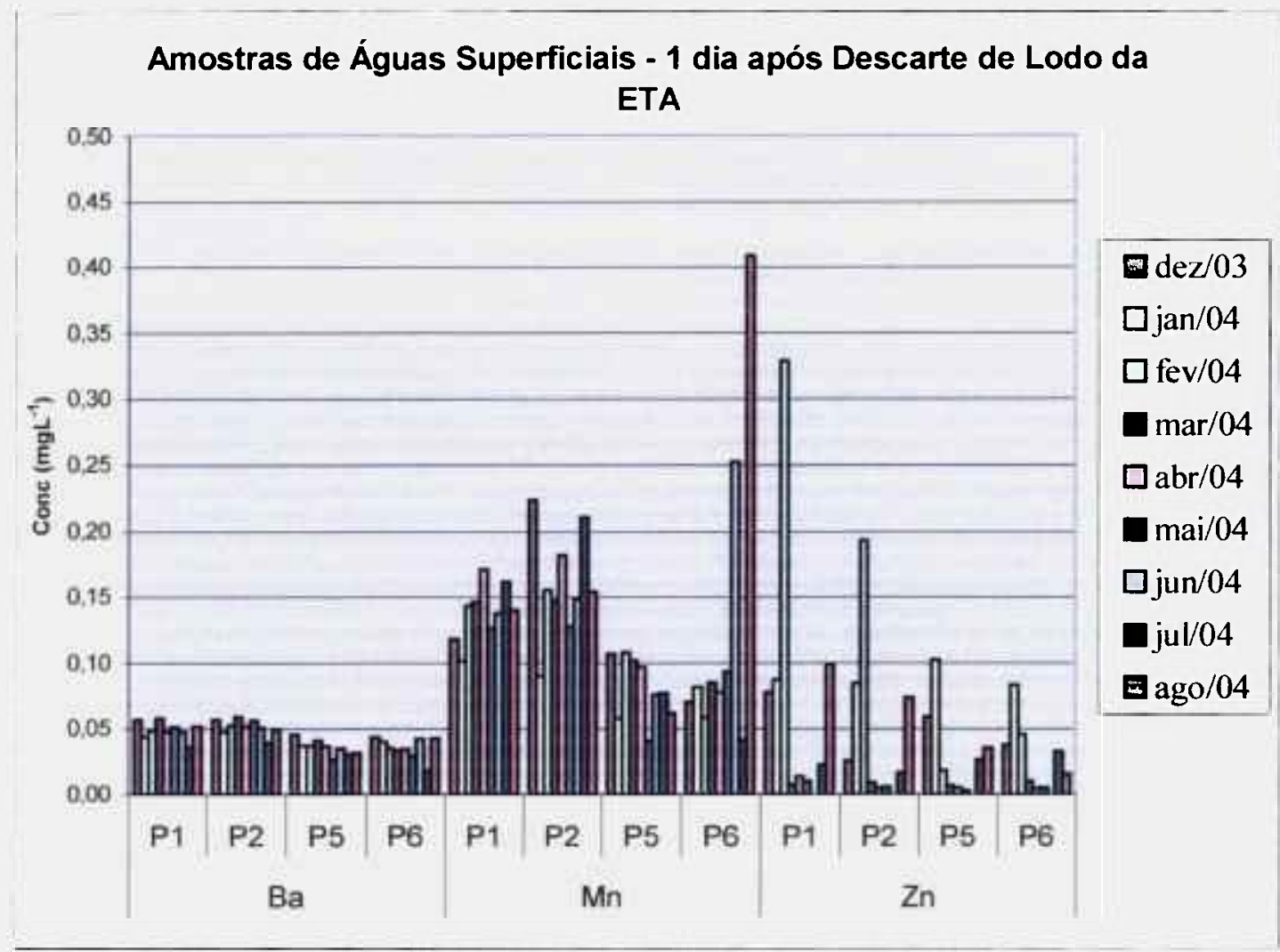

FIGURA 47 - Concentrações de elementos traços em amostras de águas superficiais.

A TAB. 52 apresenta os resultados da variação das concentrações dos metais e elementos traços nas amostras analisadas $(n=18)$ no período, aplicando-se a análise estatística descritiva.

$\mathrm{Na}$ avaliação da variação espacial e temporal do alumínio na fração solúvel das amostras de águas superficiais (FIG.48), pôde-se notar o metal encontrado em teor muito acima do estabelecido pela legislação Federal (CONAMA 357, 2005).

Apesar do lodo da ETA apresentar altas concentrações de alumínio e uma forte disponibilidade química deste elemento, como já detalhado em IV. 2, sua presença não se evidencia nas amostras de águas superficiais recolhidas nos cursos d'água, principalmente em pontos de amostragem localizados à jusante do despejo da ETA (P2 e P6), no período de 1 dia após o despejo de lodo pela ETA. 
TABELA 52 - Concentrações $\left(\mathrm{mg} . \mathrm{L}^{-1}\right)$ de metais em níveis de traços na fração solúvel de amostras de águas superficiais nos pontos de coleta.

\begin{tabular}{|c|c|c|c|c|c|c|c|}
\hline & & ncentra & (mg.L & & & & \\
\hline Elementos & $\begin{array}{c}\text { Pontos de } \\
\text { Coleta }\end{array}$ & Máximo & Minimo & $\bar{x}$ & s & Mediana & LQ \\
\hline \multirow{3}{*}{$\mathrm{Ba}$} & {$[1]$} & 0.058 & 0,036 & 0.040 & 0.0017 & 0,048 & \multirow{3}{*}{0,00003} \\
\hline & in & 0.059 & 0.040 & 0.051 & $11,(x) 6$ & 0.052 & \\
\hline & $\frac{115}{1 *_{1}}$ & $\begin{array}{l}1.046 \\
0.043\end{array}$ & $\begin{array}{l}0.026 \\
0.018\end{array}$ & $\begin{array}{l}9.036 \\
0.135\end{array}$ & $\begin{array}{l}10.916 \\
(1)(0) 18\end{array}$ & $\begin{array}{l}0,037 \\
0,035\end{array}$ & \\
\hline \multirow{4}{*}{$\mathrm{Co}$} & $p_{1}$ & 0.013 & 0,006 & 18.6113 & $(f(x)\}$ & 0.011 & \multirow{4}{*}{0,0048} \\
\hline & 12 & 0.014 & 0.005 & 0.010 & $v \cdot(\mathbf{x}) 4$ & 0.011 & \\
\hline & 115 & 0.013 & 0,004 & $0,19 / 9$ & 1). .004 & 0.010 & \\
\hline & Bs & (1).013 & 0.007 & 0,010 & $n .003$ & 0.010 & \\
\hline \multirow{4}{*}{ B } & $m$ & 0.027 & 0.014 & 10.019 & p.006 & 0,018 & \multirow{4}{*}{0,0038} \\
\hline & 12 & 0.032 & 0.011 & 8.020 & 0.007 & 0.020 & \\
\hline & p.5 & 0.015 & 0,002 & 0,008 & 0.006 & 0.006 & \\
\hline & itis & 0.018 & & 0,008 & $0 .(x) 7$ & 2.006 & \\
\hline \multirow{3}{*}{ Al } & $\mathrm{pl}$ & & $\begin{array}{l}0,017 \\
0,028\end{array}$ & $\begin{array}{l}0.097 \\
0.163\end{array}$ & $\begin{array}{l}10.1600 \\
0.0993\end{array}$ & $\begin{array}{l}0,081 \\
0,147\end{array}$ & \multirow{3}{*}{0,0005} \\
\hline & $\frac{p 2}{p 5}$ & 0.404 & 0.037 & 0,174 & 0,106 & 0.869 & \\
\hline & in & 0.185 & 0,045 & 0.134 & 0,043 & 0.147 & \\
\hline \multirow{4}{*}{ V } & $P_{1}$ & 0.1111 & 0.011 & 0.011 & - & 0.011 & \multirow{4}{*}{0,0074} \\
\hline & 12 & 0,012 & 0.008 & 0.010 & 0.003 & 0.010 & \\
\hline & ps & 0.017 & 0.015 & 0.016 & $0 ., 001$ & 0.016 & \\
\hline & $p$ & 0.1718 & 0.016 & 0.017 & 1.,.601 & 0.017 & \\
\hline \multirow{4}{*}{$\mathrm{Cr}$} & $P_{1}$ & 0.032 & 0.007 & 0,018 & 0.011 & 0,018 & \multirow{4}{*}{0,0004} \\
\hline & 12 & 0,030 & 0,004 & 0.017 & 0,012 & 0.011 & \\
\hline & $\mathrm{ps}$ & 0.6313 & 0.006 & 0.0118 & 0,012 & 10,012 & \\
\hline & $p 6$ & $0,0,141$ & 0,006 & 0.014 & $0,0,013$ & 0.012 & \\
\hline \multirow{4}{*}{ Mn } & $P 1$ & 0.171 & 0.101 & 0.138 & 0.021 & 0,140 & \multirow{4}{*}{0,0001} \\
\hline & $m_{2}$ & 0,223 & 0.090 & 0.160 & 0.044 & 0.154 & \\
\hline & PS & 0.108 & 0.041 & $0.0 \times 1$ & 0.024 & 0,077 & \\
\hline & in & 0.4188 & 0.042 & 0.139 & 0.121 & 0.082 & \\
\hline \multirow{4}{*}{$\mathrm{Ni}$} & $p_{1}$ & 0.1 .23 & 0,002 & $0.1(x) 18$ & 1,010 & 8.004 & \multirow{4}{*}{0,0016} \\
\hline & D. & 0.025 & 0,002 & 0.0099 & 11.011 & 0.005 & \\
\hline & Ps & 0.029 & 0.0012 & 0,013 & $\pi, 012$ & 0.011 & \\
\hline & 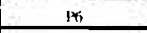 & 0.030 & 0.002 & 0.014 & 0,013 & 0,012 & \\
\hline & pl & 0.0104 & 0.004 & 0.0014 & • & 0.004 & \\
\hline $\mathrm{Cu}$ & 2 & 0.001 & 0.0013 & $0 .(x) 4$ & 0.001 & 0,004 & 0.0028 \\
\hline & ps & 0.015 & 0.903 & 0.0099 & $0 .(0) \times$ & 0.009 & \\
\hline & 1*o & 0.016 & n.,.00s & (1), & $0(10) 8$ & 0.010 & \\
\hline & ili & 1),328 & 0,007 & 10.0194 & 7).107 & 0,051 & \\
\hline $\mathrm{Zn}$ & 2 & 0.193 & 0.0015 & 0.0152 & $0,1,165$ & 0.020 & 0,0001 \\
\hline & 15 & 0.103 & 1)(1) (x) 3 & 1). 1.132 & $0,01,1.4$ & 0,022 & \\
\hline & th & 0,083 & 0.005 & 1), 1,129 & $01,1,127$ & 0.024 & \\
\hline & in & 0.019 & 0.002 & 18,011 & $13,(10) 8$ & 0.012 & \\
\hline Mo & 12 & 11)(1122 & 0.003 & 0.1011 & a.010 & 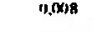 & 0,0018 \\
\hline & 1.5 & 0.021 & 0.001 & (1).(9) 8 & (1)(1) & 0.0916 & \\
\hline & is & 0.1222 & $0,0.0 \times 6$ & 1).012 & $(1),(x) 9$ & 00.008 & \\
\hline & 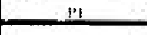 & 0.011 & 0.,005 & $0.0 \mathrm{KH}$ & 0.003 & 0,008 & \\
\hline $\mathrm{Ag}$ & 12 & 0,1112 & 0.002 & $0,0 \times 17$ & 0,0077 & 0.0007 & 0,0026 \\
\hline & B.5 & 0.147 & 0,006 & 1), (1233 & 0.1222 & 0,015 & \\
\hline & J* & (1):44) & 0.009 & 0.025 & 0,0121 & 0.016 & \\
\hline & III & tiansese & $0 ., 001$ & $4,(0) 3$ & $08,(x) 4$ & 0.002 & \\
\hline $\mathrm{Cd}$ & $m$ & $0 ., 110$ & 0.1001 & $0,(x) 4$ & $0,(104$ & 0.002 & 0,0001 \\
\hline & $p_{1}$ & 0.010 & $\begin{array}{l}0.001 \\
0.001\end{array}$ & $\begin{array}{l}0 .(x) 4 \\
11:(n) 4\end{array}$ & $\begin{array}{l}0.1004 \\
0.104\end{array}$ & $\begin{array}{l}0.002 \\
0.002\end{array}$ & \\
\hline & $P_{1}$ & 0.017 & 0.046 & 0.012 & 1). $(008$ & 0.012 & \\
\hline Sn & $p_{2}$ & 0.080 & 0,010 & 0.037 & 0.1004 & 0,020 & 0.020 \\
\hline in & ps & 0.124 & 0.011 & 0,0177 & 0.006 & 0.017 & \\
\hline & $p_{1}$ & 金(x)2 & 0.010 & $n, 015$ & 0,005 & 0.014 & \\
\hline & 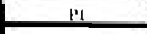 & 0.01022 & {$[,(x) 1$} & $13,(x) 1$ & $0.1 \%) 1$ & $0 .(x) 1$ & \\
\hline $\mathrm{Pb}$ & $m_{2}$ & $0.1(1) 22$ & $0 .(1) 2$ & 0.102 & - & 0.002 & 0,001 \\
\hline 8 & P5 & 1)..$(x / 4$ & $0.0 \times 13$ & 0.0014 & $(1),(x) 10$ & 0.0104 & \\
\hline & 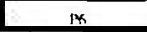 & 0.004 & 0.002 & 0.1013 & (1). .001 & 0.003 & \\
\hline
\end{tabular}

"Considerando 6 coletas de dados, 1 dia após o descarte de lodo, no periodo da pesquisa. 


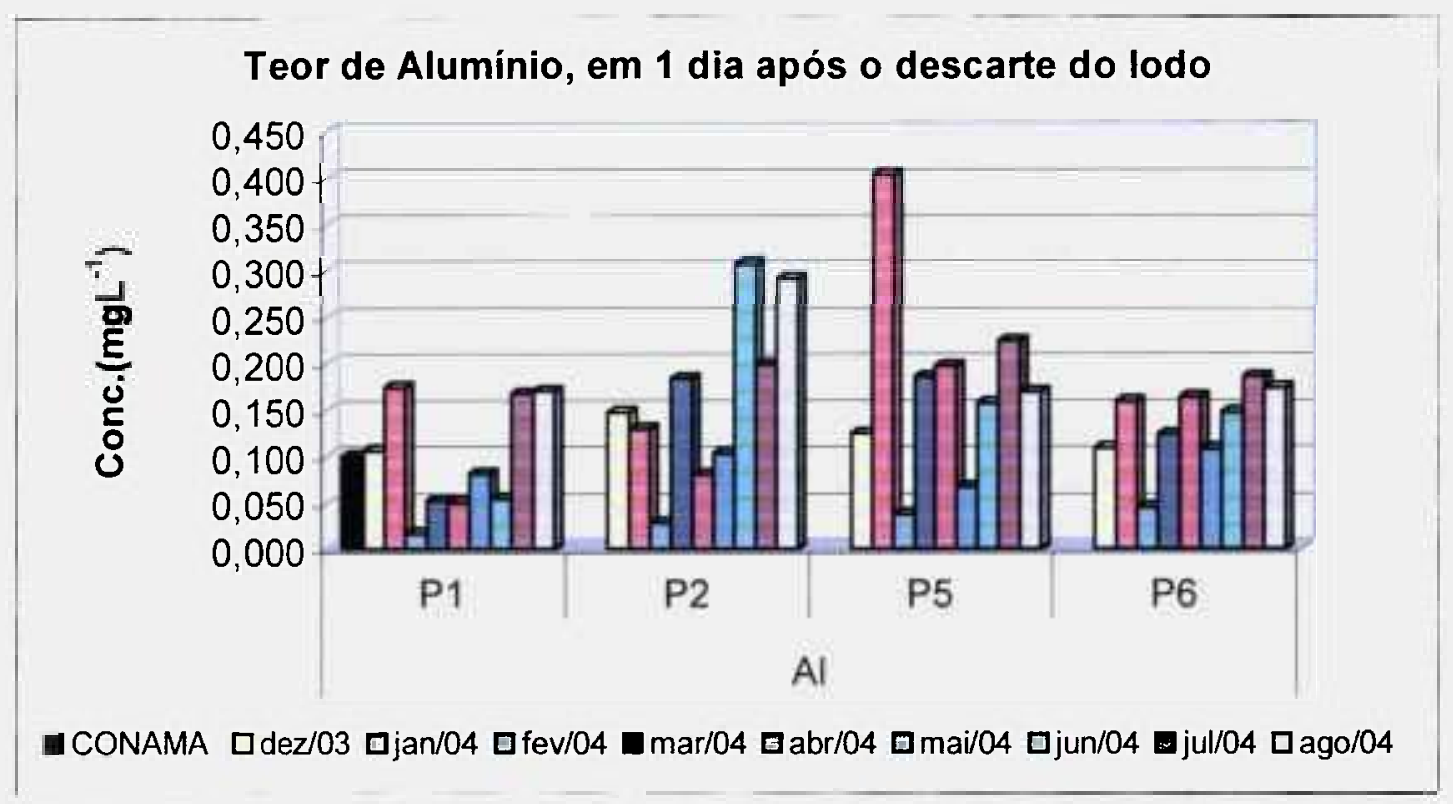

FIGURA 48 - Teor de alumínio em águas superficiais, em 1 dia após descarte do lodo.

Uma avaliação realizada bimestralmente em 50 variáveis de qualidade de recursos hídricos em 330 pontos de amostragem em diversas regiões do estado de São Paulo pela CETESB no ano de 2004, demonstrou que, apesar de alguns parâmetros de qualidade terem apresentado não conformidades, em desacordo com o Decreto Estadual $\mathrm{N}^{\circ}$ $10.755 / 77$, muitos dos resultados encontrados foram devidos a fatores ambientais naturais. Algumas substâncias químicas, como o alumínio, ferro e manganês, ocorrem naturalmente em quantidade significativa nos solos paulistas, incluindo a Região Metropolitana de São Paulo e que, por esse motivo, parte dessas substâncias é carreada para os corpos d'água em decorrência do manejo agrícola inadequado ou das chuvas (CETESB, 2004).

Na FIG.49 é mostrada a porcentagem de resultados não conformes com os padrões fundamentados para águas doces destinadas ao abastecimento humano, após tratamento convencional, e à proteção de comunidades aquáticas (Classe 2), conforme estabelecido pela Resolução CONAMA 357. Observa-se que 93\% dos resultados obtidos para alumínio e $44 \%$ dos resultados obtidos para manganês estão acima do estabelecido pela legislação ambiental naquele período. Contudo, os resultados se encontram diretamente associados a fenômenos de erosão quando da ocorrência de chuvas, especialmente pelo fato de que a maioria dos pontos (cerca de $70 \%$ ) de amostragem monitorados pela CETESB se encontra enquadrada como Classe 2. 
Porcentagem de Resultados Não Conformes com a Classe 2 - Resolução CONAMA 20/86 Corpos d'Água do Estado de São Paulo

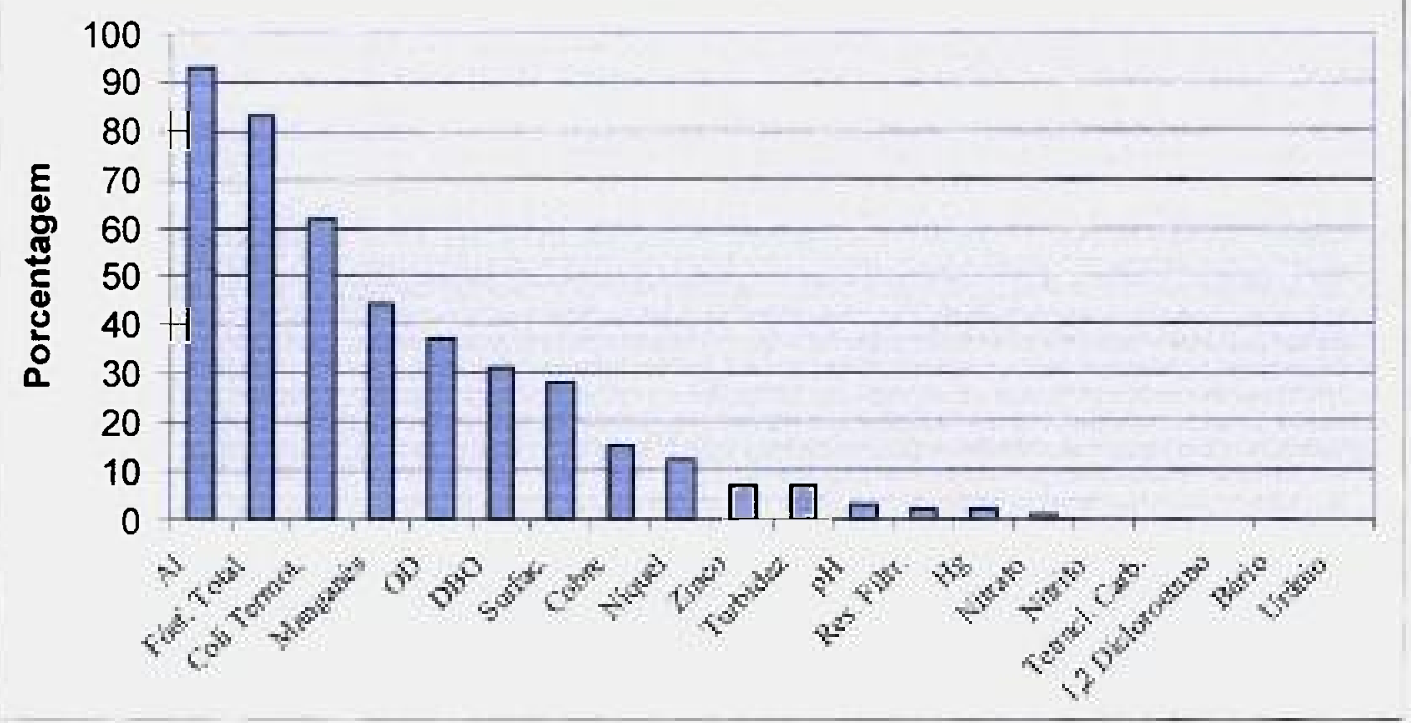

FIGURA 49 - Porcentagem de resultados não conformes com a Classe 2 (CETESB, 2004).

Neste trabalho, com exceção do alumínio, a maioria dos elementos analisados no periodo apresentou concentrações inferiores aos níveis estabelecidos para amostras de águas denominadas Classe 2 (CONAMA 357, 2005). Por outro lado, também não foram observadas variações significantes entre coletas realizadas ao longo dos meses no decorrer do estudo, o que demonstra haver uma rápida dispersão dos resíduos da ETA, apesar de diferenças no clima observadas no período (TAB.39). A constatação de que o despejo do lodo apresenta pouco impacto nas águas superficiais tanto em um rio com uma pequena vazão (Rio Sem Nome), quanto em um rio volumoso, sugere que o efeito do lodo da ETA deva ser mais significante em amostras de sedimento e na biota. $O$ uso de sulfato de alumínio como agente coagulante pela ETA de Registro apresentou pouca ou nenhuma influência nos parâmetros naturais de qualidade das águas nos pontos de coleta a jusante do despejo.

A comparação dos dados obtidos com um trabalho realizado por Lemes (2001) onde foram estudadas as duas bacias hidrográficas no Estado de São Paulo mostrou, de acordo com a TAB. A (Apêndice), que os dados obtidos neste estudo são similares aos valores encontrados em outras regiões do estado de São Paulo. 
Foram analisados alguns parâmetros físico-químicos nas amostras de água para avaliação da influência do despejo dos resíduos da ETA. Foram verificados a variabilidade dos niveis de oxigênio dissolvido, turbidez, alcalinidade, dureza, sólidos totais, sólidos totais fixos, sólidos voláteis e $\mathrm{pH}$, durante o período de coleta. As FIG.50 e 51 mostram os resultados obtidos por meio de Box-plots.

Quando se comparam os gráficos obtidos, percebem-se caracteristicas similares entre os pontos de coleta P1 e P2, apontando nenhuma influência do descarte do lodo da ETA no local de coleta no ponto de coleta P2, à jusante do próprio despejo. A similaridade também observada entre P5 e P6 mostra que, para os parâmetros medidos, não se observa impacto do descarte do lodo no deságüe do Rio Sem Nome no Rio Ribeira de Iguape. Por outro lado, a semelhança dos gráficos entre os pontos P3 e P4, apontam que o Ribeirão de Registro não causa qualquer alteração química relevante quando deságua no Rio Sem Nome. Os mesmos parâmetros utilizados para avaliação por Box-plots foram submetidos à análise estatística multivariada por dendogramas (Statistica 5.1 - Edição 98), onde cada parâmetro físico-químico é tratado como uma variável independente. Apesar da aplicação de dendogramas apontar para a mesma conclusão daquela obtida quando se utiliza o método de box-plots, seu uso possibilita evidenciar a distribuição geográfica dos cursos d’água no entorno da ETA de Registro, quando se relaciona a similaridade observada entre os pontos de coleta.

Conforme mostrado nas FIG.52 e 53, os pontos de coleta P1 e P2 apresentam-se agrupados, pois são localizados no mesmo curso d'água (rio Sem Nome); o mesmo ocorre com os pontos P5 e P6, que se encontram no rio Ribeira de Iguape. Os pontos P3 e P4 mostram a influência do deságüe do Ribeirão de Registro no rio Sem Nome e mesmo no Ribeira de Iguape, o que aparece associado em alguns dos gráficos obtidos. O gráfico demonstra também que os parâmetros utilizados são adequados para caracterizar e associar quimicamente cursos d'água diferentes. Os gráficos referentes aos meses de coleta realizados apresentaram a mesma distribuição dos pontos de coletas em períodos de um dia antes e um dia depois da descarga do lodo da ETA. 

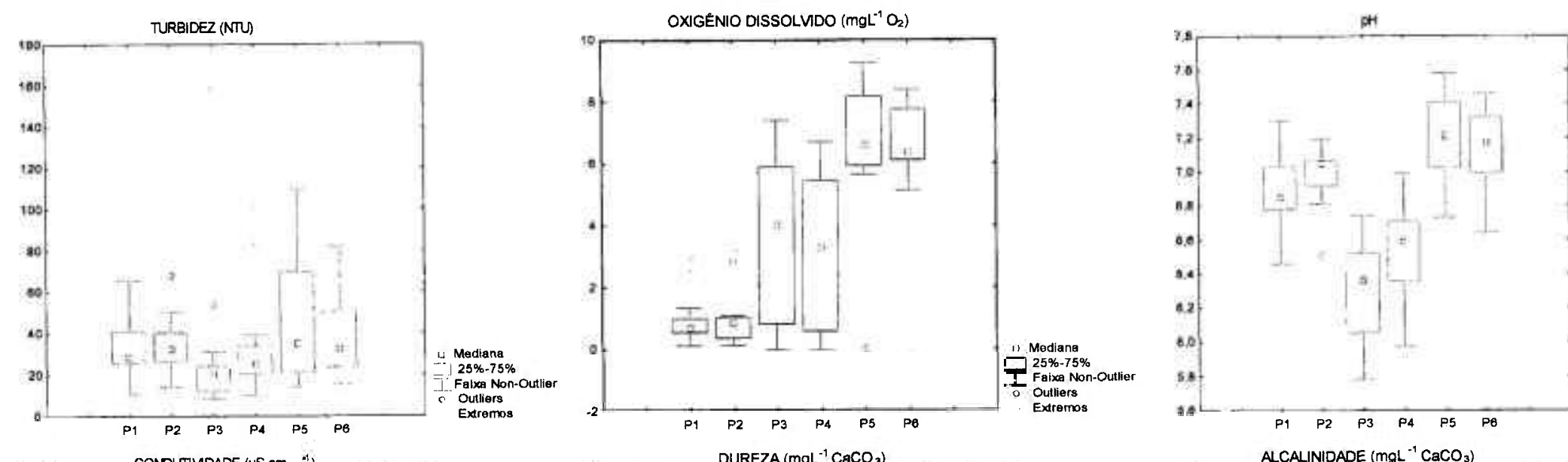

Modiana

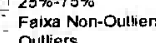
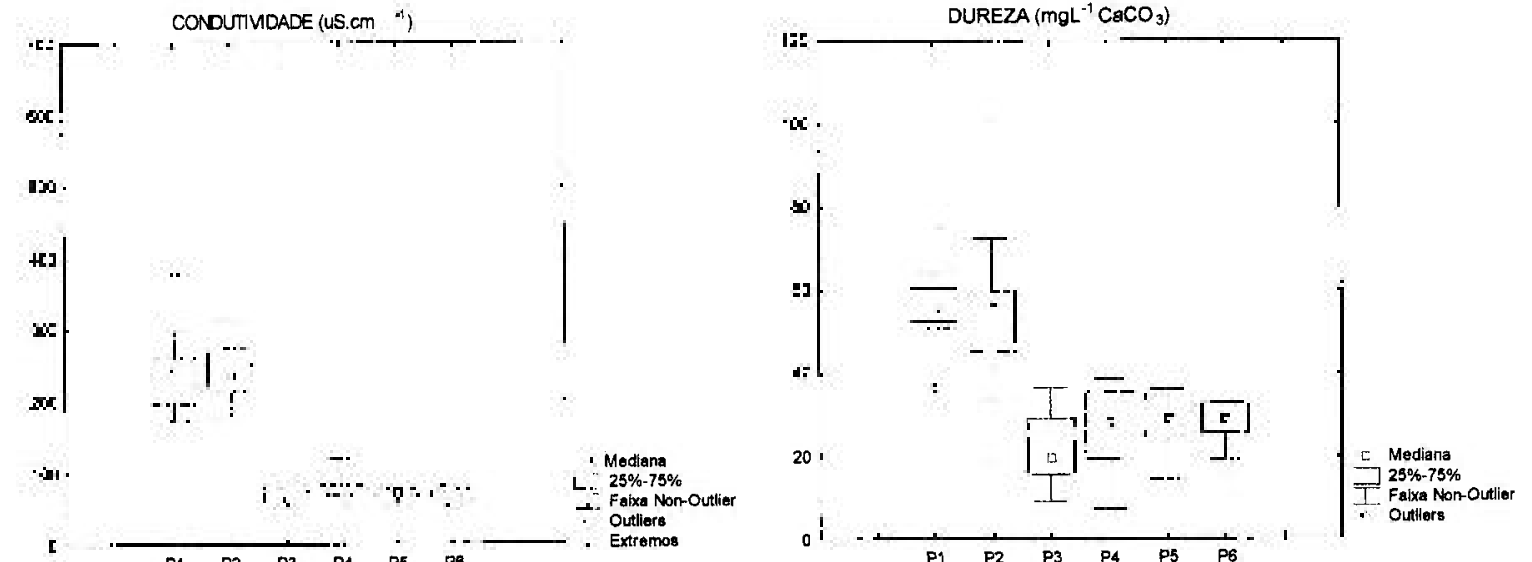

ALCALINIDADE (mgL ${ }^{-1} \mathrm{CaCO}_{3}$ )

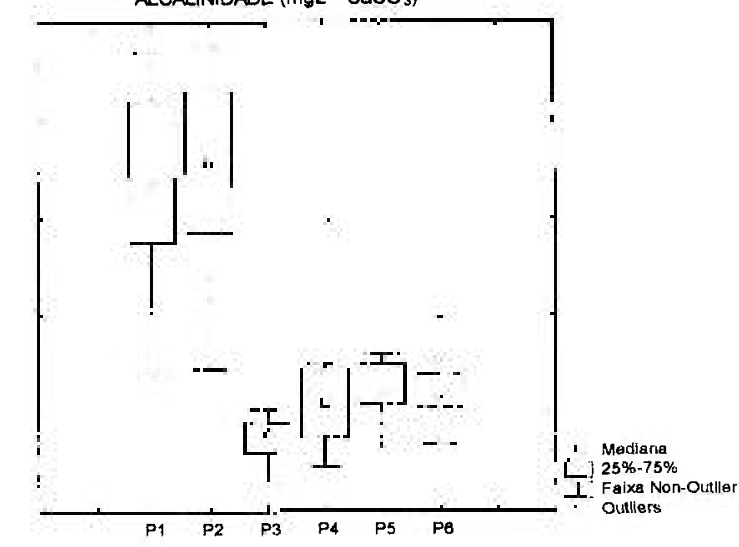

FIGURA 50 - Box plots dos parâmetros medidos em 1 dia após descarte do lodo. 


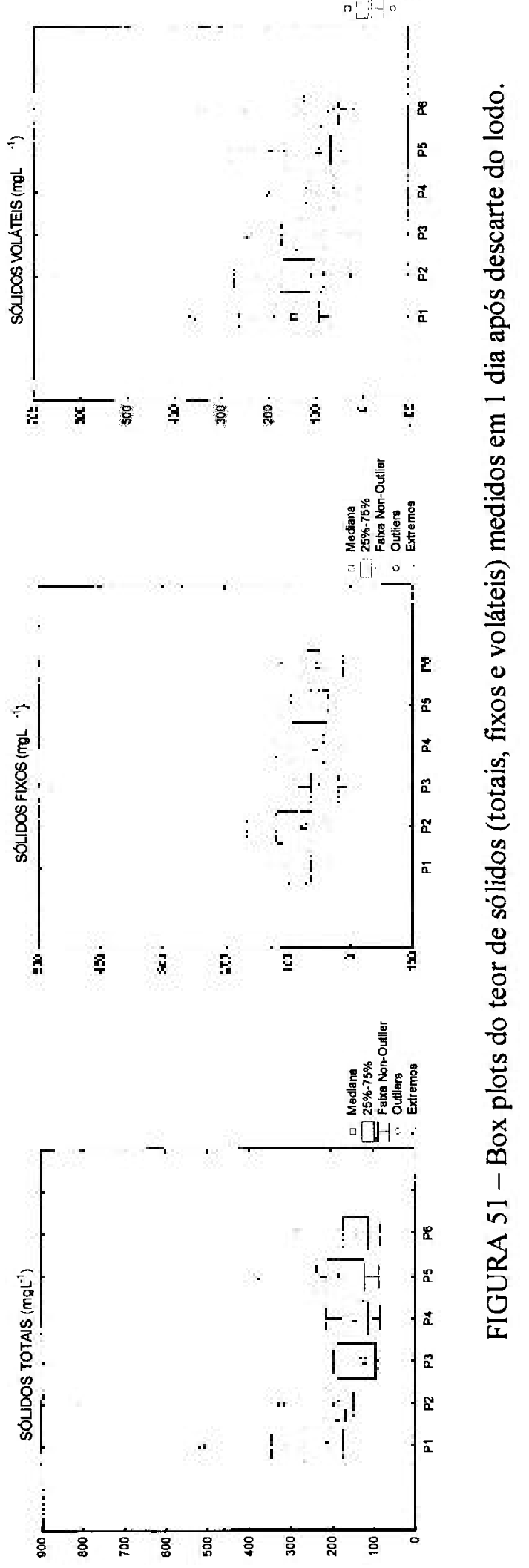



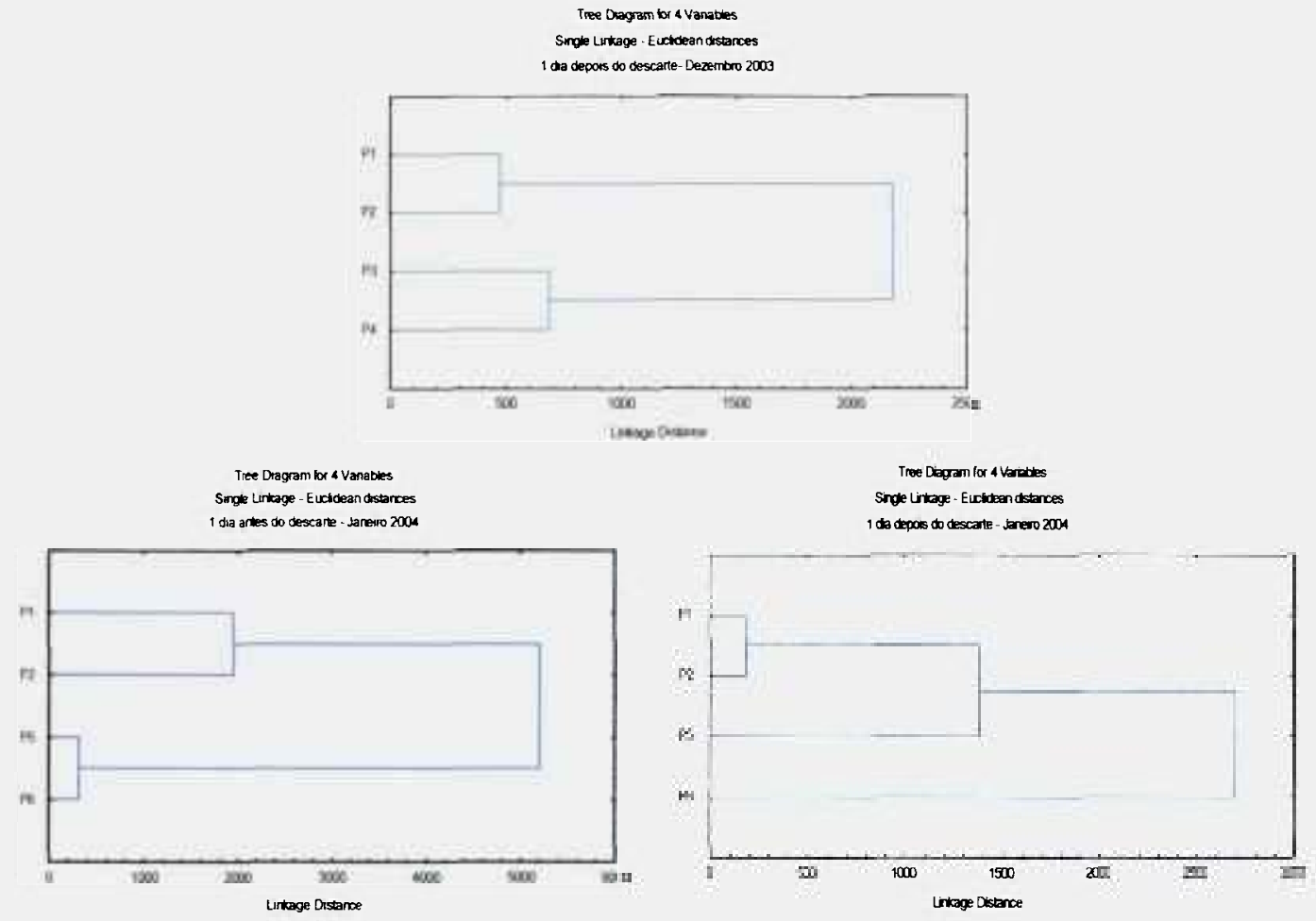

The Dagrom lor 4 Varatien

Single Lrkage - Eucbizan dstances

1 de artes do descate - Feverero 2004

Tree Dagrom for 4 variatioc

Single Linkage - Elchim ditances

10 depos do descatie - Feverio 200
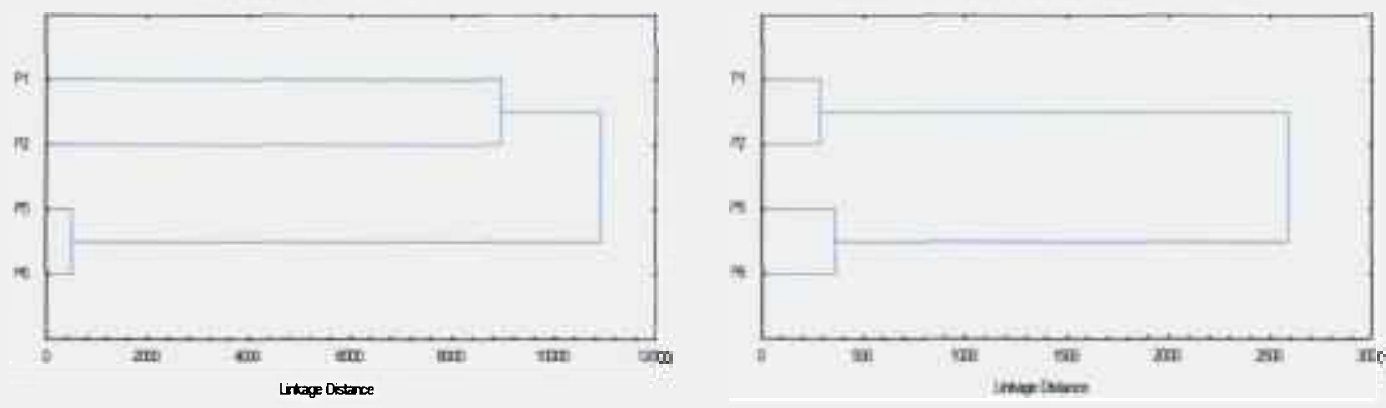

Tree Diagram lor 4 Vanaties

Single Lirkage - Eucidean distarces

1 dia antes do descaite - Marro 2004

Tree Dagram for 4 Varables

Surce Lrikape - Euctidean distances

1 ho depors do descarte - Março 2004
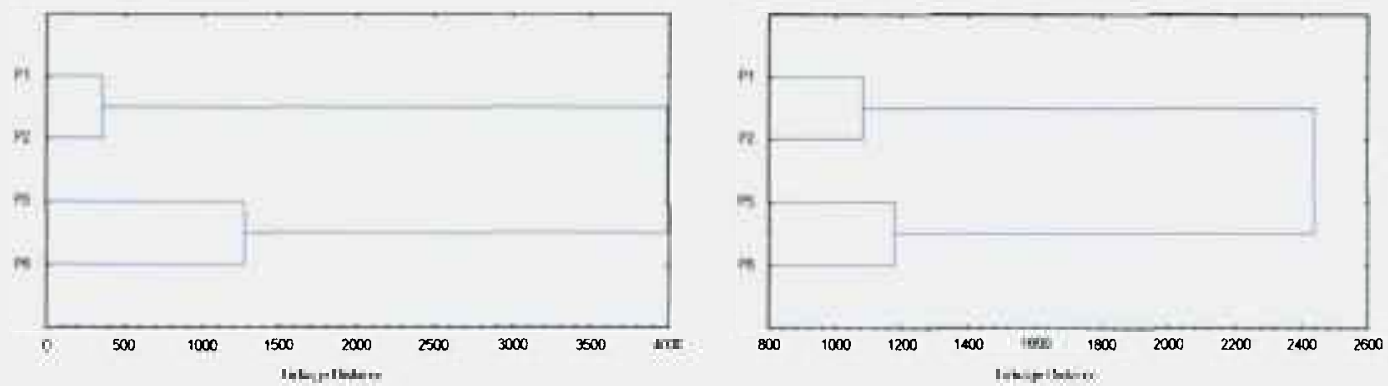

FIGURA 52 - Dendogramas representando a correlação entre pontos de coleta, por período de amostragem, a partir dos parâmetros utilizados na avaliação: oxigênio dissolvido, turbidez, alcalinidade, dureza, sólidos totais, sólidos totais fixos e sólidos voláteis. 

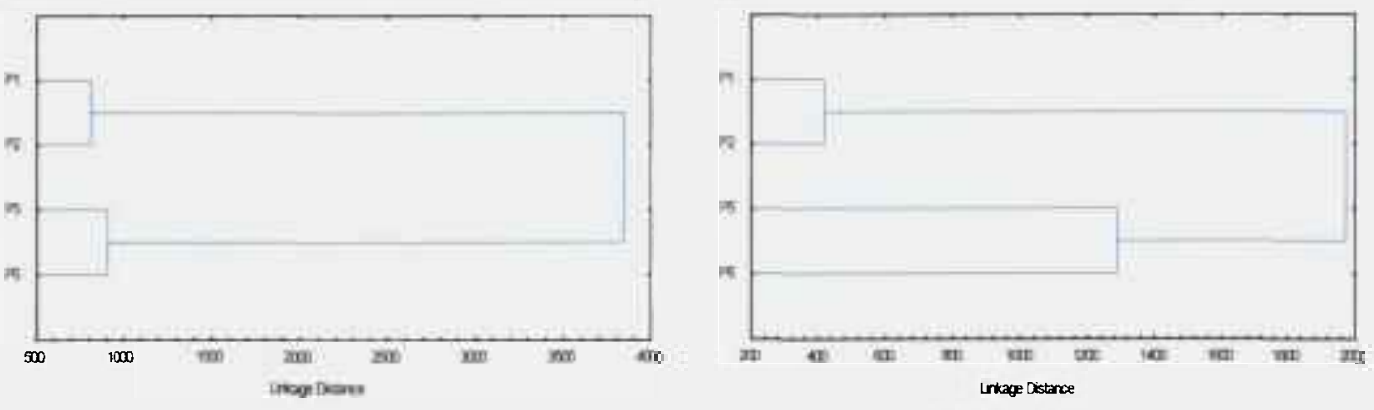

Tree Dagram for 4 varave

Sinde Inkage - Eurfiden ditences

Tree Dagrom for 4 Varates

1 do antes do descate - Maro 2004

singe inkag - Euchesen dstances

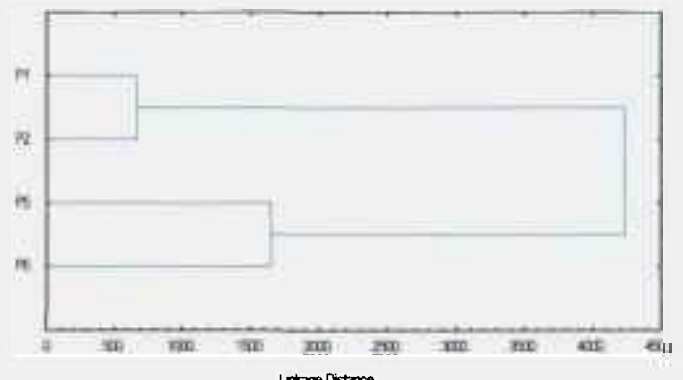

1 do depos do descate - Neio 2001

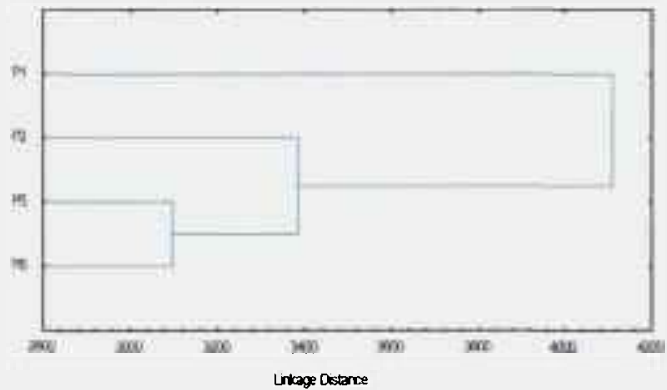

Single Linkage - Euctidean distences

I da artes do descarte - Jinto 2004

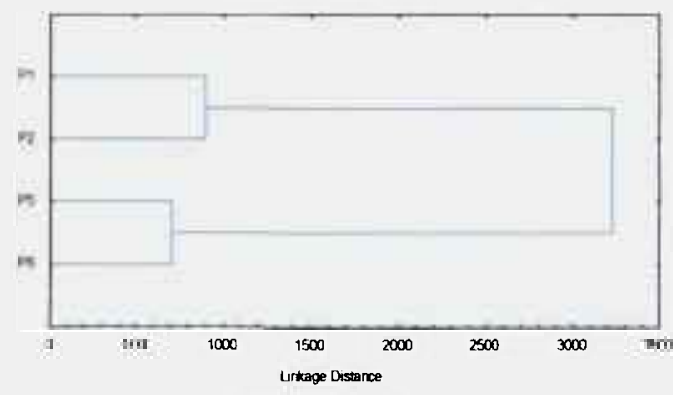

Tnee Dagrasm bor 4 Vanables

Sugle Linkage - Eucideandistancer

t da depas do descane - Jutro 2004

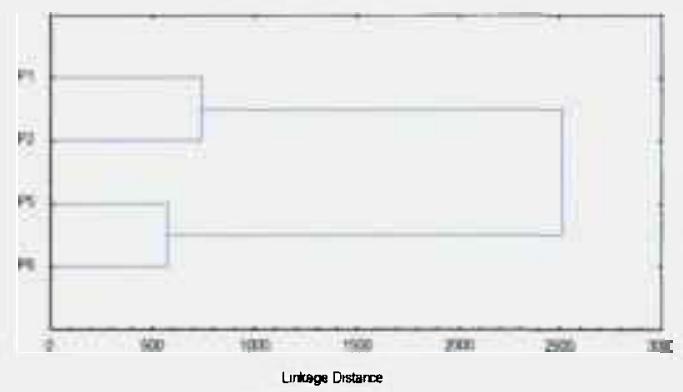

Tree Dagram tor 4 Variablos

Single Linkage - Eurideren dstances

1 dá artes do descante - Jumo 2004

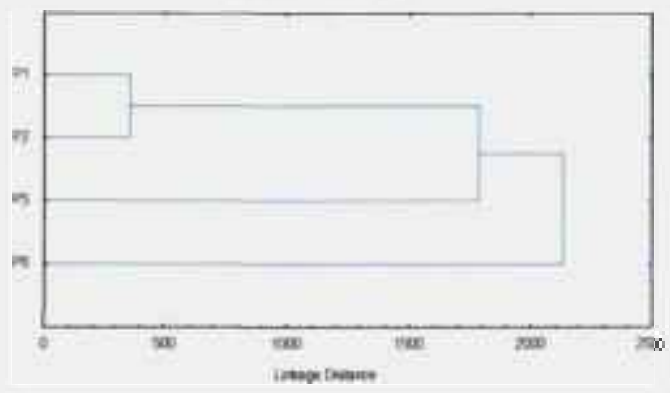

Tree Dagarn or 4 Varradios

Single Linkage - Euchoesn dtstances

1 dia depors do descarte - Jutho 2004

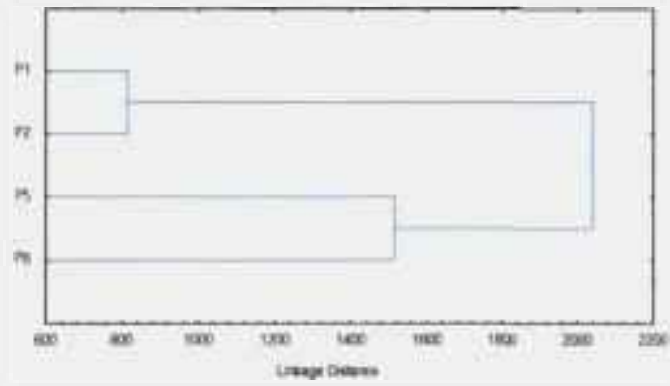

FIGURA 53 - Dendogramas representando a correlação entre pontos de coleta, por período de amostragem, a partir dos parâmetros utilizados na avaliação: oxigênio dissolvido, turbidez, alcalinidade, dureza, sólidos totais, sólidos totais fixos e sólidos voláteis. 


\subsection{Cálculos dos índices de qualidade de água}

Foram calculados os índices de IET(P), IPMCA e IVA, correspondentes ao periodo de chuvas e de estiagem, baseando-se nos dados obtidos e listados nas TAB.53 e 54 .

TABELA 53 - Parâmetros considerados no período de chuvas (Dez./03 - Fev./04).

\begin{tabular}{|c|c|c|c|c|c|c|c|c|}
\hline & & & \multicolumn{6}{|c|}{ Período de Coleta } \\
\hline & \multirow[t]{2}{*}{ Variáveis } & & \multicolumn{2}{|c|}{ Dezembro } & \multicolumn{2}{|c|}{ Janeiro } & \multicolumn{2}{|c|}{ Fevereiro } \\
\hline & & & P1 & $\mathrm{P} 2$ & P1 & P2 & P1 & $\mathrm{P} 2$ \\
\hline \multirow{4}{*}{$\begin{array}{c}\text { PE } \\
\text { (IPMCA) }\end{array}$} & O.D. & (mg. $\mathrm{L}^{-1} \mathrm{O}_{2}$ ) & 2,63 & 3,26 & 3,06 & 2,84 & 0,54 & 0,45 \\
\hline & $\mathrm{pH}$ & & 6,82 & 6,92 & 6,71 & $\overline{7,06}$ & 6,82 & 6,98 \\
\hline & $\mathrm{Cd}$ & $\left(\mathrm{mg} \cdot \mathrm{L}^{-1}\right)$ & $<0,0001$ & $<0,0001$ & $<0,0001$ & $<0,0001$ & 0,001 & 0,002 \\
\hline & $\mathrm{Cr}$ & $\left(\mathrm{mg} . \mathrm{L}^{-1}\right)$ & 0,007 & 0,01 & $<0,003$ & $<0,003$ & $<0,003$ & 0,004 \\
\hline \multirow{5}{*}{$\begin{array}{c}\text { ST } \\
\text { (IPMCA) }\end{array}$} & $\mathrm{Cu}$ & $\left(m g . L^{-1}\right)$ & $<\mathrm{LQ}$ & $<\mathrm{LQ}$ & $<\mathrm{LQ}$ & $<\mathrm{LQ}$ & $<\mathrm{LQ}$ & $<\mathrm{LQ}$ \\
\hline & $\mathrm{Pb}$ & $\left(m g . L^{-1}\right)$ & 0,001 & 0,002 & $*$ & * & $<0,001$ & $<0,001$ \\
\hline & $\mathrm{Hg}$ & $\left(\mathrm{mg} \cdot \mathrm{L}^{-1}\right)$ & $*$ & * & $*$ & $*$ & $*$ & * \\
\hline & $\mathrm{Ni}$ & $\left(\mathrm{mg} \cdot \mathrm{L}^{-1}\right)$ & 0,001 & $<\mathrm{LQ}$ & $<\mathrm{LQ}$ & $<\mathrm{LQ}$ & 0,003 & 0,003 \\
\hline & $\mathrm{Zn}$ & $\left(\mathrm{mg} \cdot \mathrm{L}^{-1}\right)$ & 0,078 & 0,0253 & 0,087 & 0,085 & 0,328 & 0,193 \\
\hline IET & $P$ & $\left(\mathrm{mg} \cdot \mathrm{L}^{-1}\right)$ & 0,522 & 0,297 & 0,207 & 0,154 & 0,249 & 0,140 \\
\hline
\end{tabular}

* Não determinado.

TABELA 54 - Parâmetros considerados no período de estiagem (Jun/04 - Ago/04).

\begin{tabular}{|c|c|c|c|c|c|c|c|c|}
\hline & & & \multicolumn{6}{|c|}{ Período de Coleta } \\
\hline & \multirow[t]{2}{*}{ Variáveis } & & \multicolumn{2}{|c|}{ Junho } & \multicolumn{2}{|c|}{ Julho } & \multicolumn{2}{|c|}{ Agosto } \\
\hline & & & P1 & $\mathrm{P} 2$ & P1 & P2 & P1 & $\mathrm{P} 2$ \\
\hline \multirow{4}{*}{$\begin{array}{c}\text { PE } \\
\text { (IPMCA) }\end{array}$} & O.D. & $\left(\mathrm{mgL}^{-1} \mathrm{O}_{2}\right)$ & 0,66 & 1,08 & 0,70 & 0,35 & 0,47 & 0,42 \\
\hline & $\mathrm{pH}$ & & 7,10 & 7,06 & 6,88 & 6,89 & 6,88 & 6,91 \\
\hline & $\mathrm{Cd}$ & (mg. $\left.L^{-1}\right)$ & $<0,0001$ & $<0,0001$ & $<0,0001$ & $<0,0001$ & 0,009 & 0,01 \\
\hline & $\mathrm{Cr}$ & $\left(m g . L^{-1}\right)$ & 0,009 & 0,005 & $<0,002$ & 0,002 & $<0,003$ & 0,004 \\
\hline \multirow{5}{*}{$\begin{array}{c}\mathrm{ST} \\
(\mathrm{IPMCA})\end{array}$} & $\mathrm{Cu}$ & $\left(\mathrm{mg} \cdot \mathrm{L}^{-1}\right)$ & $<\mathrm{LQ}$ & $<\mathrm{LQ}$ & 0,004 & 0,005 & $<\mathrm{LQ}$ & 0,003 \\
\hline & $\mathrm{Pb}$ & $\left(\mathrm{mg} \cdot \mathrm{L}^{-1}\right)$ & $<0,001$ & $<0,001$ & $*$ & $*$ & * & $*$ \\
\hline & $\mathrm{Hg}$ & $\left(\mathrm{mg} \cdot \mathrm{L}^{-1}\right)$ & $*$ & * & $*$ & * & $*$ & $*$ \\
\hline & $\mathrm{Ni}$ & $\left(\mathrm{mg} \cdot \mathrm{L}^{-1}\right)$ & $<\mathrm{LQ}$ & $<\mathrm{LQ}$ & 0,004 & 0,007 & 0,023 & 0,025 \\
\hline & $\mathrm{Zn}$ & $\left(\mathrm{mg} \cdot \mathrm{L}^{-1}\right)$ & $<0,010$ & $<0,010$ & 0,023 & 0,016 & 0,099 & 0,074 \\
\hline IET & $\mathbf{P}$ & $\left(\mathrm{mg} \cdot \mathrm{L}^{-1}\right)$ & 0,124 & 0,109 & 0,144 & 0,186 & 0,831 & 1,34 \\
\hline
\end{tabular}

*Não determinado. 
Os cálculos do IET $(\mathrm{P})$ para os dois períodos foram executados conforme a equação 5 e classificados conforme o Estado Trófico (Índice de Carlson Modificado). Os valores médios das medidas de fósforo no periodo de chuvas e de estiagem (TAB.55) indicaram praticamente um sistema hipereutrófico (IET>74), conforme apresentado nas TAB. 10 e 56, indicando que o Rio Sem Nome já se encontra fortemente comprometido por influências antrópicas, especialmente quando são comparados os valores de IET(P) obtidos na montante e jusante do despejo da ETA. No entanto, entre os meses de junho e julho de 2004, onde o indice pluviométrico é menor, o Rio Sem Nome assume um estado eutrófico, apresentando ainda uma forte influência antrópica.

TABELA 55 - Valores de IET (P), para os períodos de chuvas e estiagem.

\begin{tabular}{|c|c|c|c|c|c|c|}
\hline & \multicolumn{2}{|c|}{ Dezembro/03 } & \multicolumn{2}{c|}{ Janeiro/04 } & \multicolumn{2}{c|}{ Fevereiro/04 } \\
\hline & P1 & P2 & P1 & P2 & P1 & P2 \\
\hline Chuvas & 87,0 & 78,9 & 73,7 & 69,4 & 76,3 & 68,0 \\
\hline & \multicolumn{2}{|c|}{ Junho/04 } & \multicolumn{2}{|c|}{ Julho/04 } & \multicolumn{2}{c|}{ Agosto/04 } \\
\hline Estiagem & P1 & P2 & P1 & P2 & P1 & P2 \\
\hline & 66,3 & 64,4 & 68,4 & 72,1 & 93,7 & 101 \\
\hline
\end{tabular}

TABELA 56 - Classificação do estado trófico (CETESB, 2005).

Estado Trófico

Oligotrófico

Mesotrófico

Eutrófico

Hipereutrófico

\section{Especificação}

Classes do IET

Corpos de água limpos, de baixa produtividade. em que não ocorrem interferências indesejáveis sobre os usos da água.

Corpos de água com produtividade intermediảria. com possíveis implicações sobre a qualidade da água, mas em níveis aceitáveis, na maioria dos casos.

Corpos de água com alta produtividade em relação às condições naturais, de baixa transparência. em geral afetadas por atividades antrópicas. em que ocorrem alterações indesejáveis na qualidade da água e interferências nos seus múltiplos usos.

Corpos de água afetados significativamente pelas elevadas concentrações de matéria orgânica e nutrientes. com comprometimento acentuado no seu uso, podendo inclusive estar associados a episódios floracões de algas e de mortandade de peixes e causar conseqüências indesejáveis sobre as atividades pecuárias nas regiōes ribeirinhas. 
Apesar desta diferença observada quanto à classificação do estado trófico, observase que o índice pluviométrico (TAB.39) apresenta pouca influência no estado de trofia do curso d'água analisado, mesmo com a variação constatada nos níveis de pluviosidade observados entre o período de estiagem em agosto/2004 $(6,3 \mathrm{~mm})$ e o periodo de chuvas, em janeiro/2004 (408,4 mm). Deste modo, comparando-se as medidas realizadas entre as estações de coleta P1 e P2, observa-se que o lodo de ETA não apresenta prováveis efeitos que influenciem a classificação do estado trófico do curso d'água receptor.

Para o cálculo do IPMCA, ponderou-se sobre os valores apresentados nas TAB.53 e 54, para o periodo de chuvas e estiagem. Os valores encontrados foram IPMCA (Chuvas) = 6 e IPMCA (Estiagem) $=6$. Portanto, pela classificação dos valores do IPMCA, as águas do rio Sem Nome podem ser classificadas como de péssima qualidade.

A classificação IVA não pode ser aplicada para o rio Sem Nome por apresentar características hipereutróficas, com um valor de IET(P) acima do limite. No entanto, somente pelas avaliações do IET(P) e do IPMCA, comprovou-se que o despejo do lodo da ETA não comprometeu as condições já existentes das águas superficiais do rio Sem Nome, conforme CETESB (2005).

\subsection{Análise de sedimentos}

Nas TAB. 57 e 58 são mostrados os resultados obtidos para o extrato lixiviado do sedimento coletado nos rios receptores do lodo da ETA, em amostragens realizadas no periodo de 1 dia após o descarte do lodo. A caracterização e localização dos pontos de amostragem foram detalhados na TAB.24. A avaliação restringiu-se aos periodos considerados mais importantes para o monitoramento, abrangendo três meses do período de chuvas (dezembro/2003 a janeiro/2004) e do periodo de estiagem (junho a agosto/2004). Os resultados obtidos foram comparados aos valores de referência TEL e PEL, estabelecidos pelo CCME (1999). As TAB. B e C (Apêndice) apresentam os resultados da variação da concentração dos metais elementos traços na fração lixiviável aplicado à análise estatística descritiva. As TAB. D a G (Apêndice) mostram um perfil dos elementos analisados nos períodos de chuvas e estiagem. 
Os elementos analisados neste estudo referem-se à fração lixiviável dos metais nos sedimentos obtidos por meio de uma digestão ácida moderada e não da fração residual dos metais (ligados à estrutura cristalina do sedimento), que seria obtida por digestão utilizando-se ácido fluorídrico.

A maioria das amostras de sedimentos analisadas, especialmente aquelas do ponto de coleta P2 (localizado a jusante do despejo da ETA), não demonstrou impacto do despejo, pois não se observou um aumento nos níveis de concentração em relação aos resultados obtidos no ponto de coleta localizado a montante (P1). Alguns elementos, como $\mathrm{Mg}, \mathrm{Cu}$ e $\mathrm{Pb}$, chegaram a apresentar valores acima dos estabelecidos por referência, porém sem associação direta com o despejo do lodo, como os valores observados no ponto P5 localizado próximo do ponto de captação da ETA, no rio Ribeira de Iguape, indicando que os valores obtidos são de origem natural. No entanto, para os dois períodos analisados, é nítido o aumento das medidas de alumínio no ponto $\mathrm{P} 2$ em relação an ponto $\mathrm{P} 1$, em praticamente todo o período de descarte avaliado, apresentando concentrações superiores a todos os outros pontos de coleta avaliados. A FIG.54 mostra os teores de alumínio encontrados entre os dois pontos.

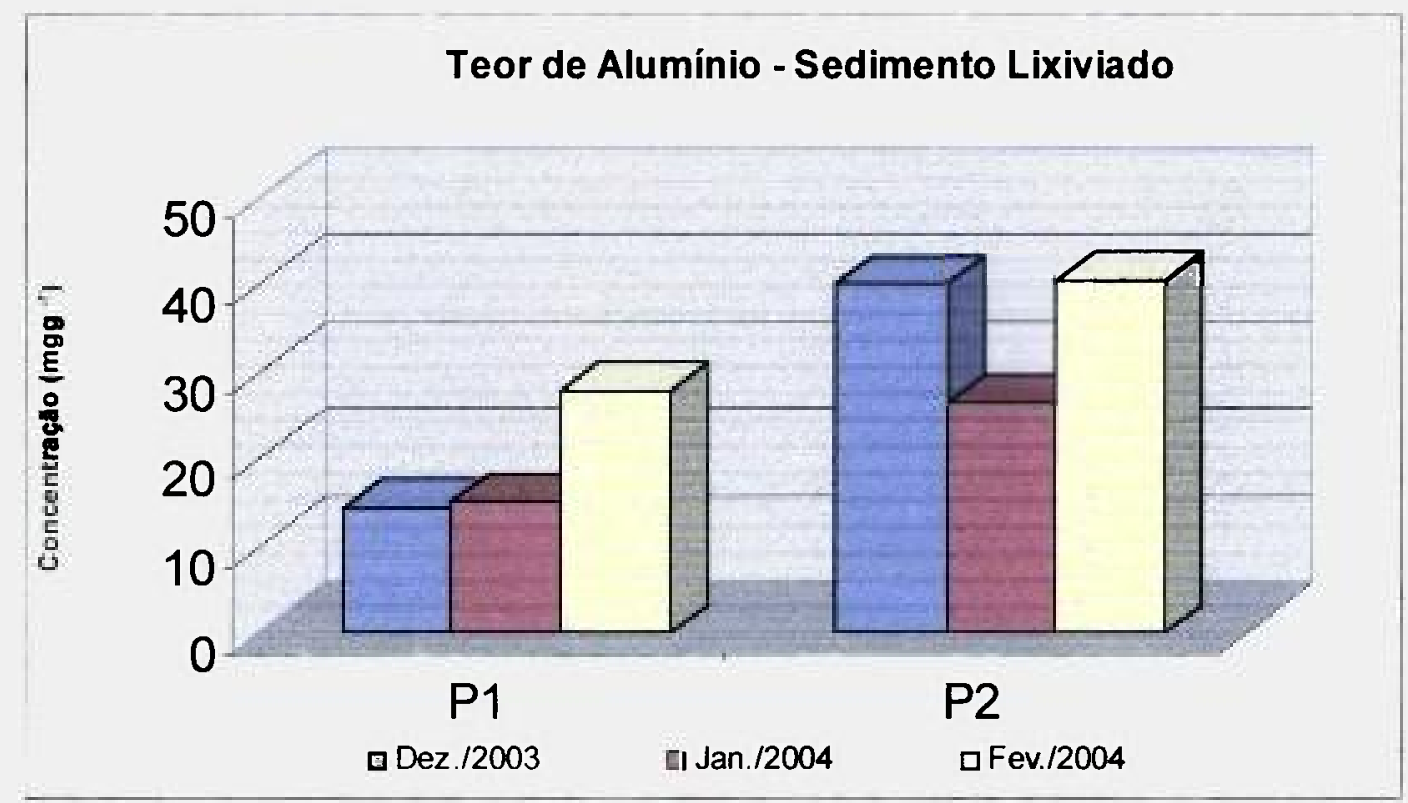

FIG.54 - Distribuição de alumínio nos pontos de coleta a montante (PI) e jusante (P2) do descarte do lodo da ETA. 
Esta constatação comprova o fato do incremento dos níveis de alumínio detectados em P2 ser oriundo de atividades antrópicas. No entanto, tanto os resultados associados ao descarte do lodo, quanto os resultados relacionados a fatores naturais detectados especialmente na montante do despejo, foram encontrados em níveis abaixo dos valores de referência (58.030 mg. $\left.\mathrm{kg}^{-1}\right)$. Quando são comparadas somente as médias dos valores obtidos para o alumínio nos períodos de chuva e estiagem e se consideram apenas os resultados provenientes do ponto de coleta $\mathrm{Pl}$ e $\mathrm{P} 2$, percebe-se que as médias obtidas em Pl são praticamente equivalentes $\left(1.185 \mathrm{mg} \cdot \mathrm{kg}^{-1}\right.$ e $\left.1.505 \mathrm{mg} \cdot \mathrm{kg}^{-1}\right)$, indicando um background natural.

Por outro lado, quando também se avaliam as médias obtidas para o alumínio no ponto de coleta $\mathrm{P} 2$, pode ser percebido um aumento nas concentrações medidas no período de estiagem (5.464 mg. $\left.\mathrm{kg}^{-1}\right)$ em relação ao período de chuvas (3.250 mg. $\left.\mathrm{kg}^{-1}\right)$, provavelmente em virtude de um menor índice de precipitação e, portanto, menor carreamento do resíduo da ETA depositado no fundo do rio Sem Nome (FIG.55).

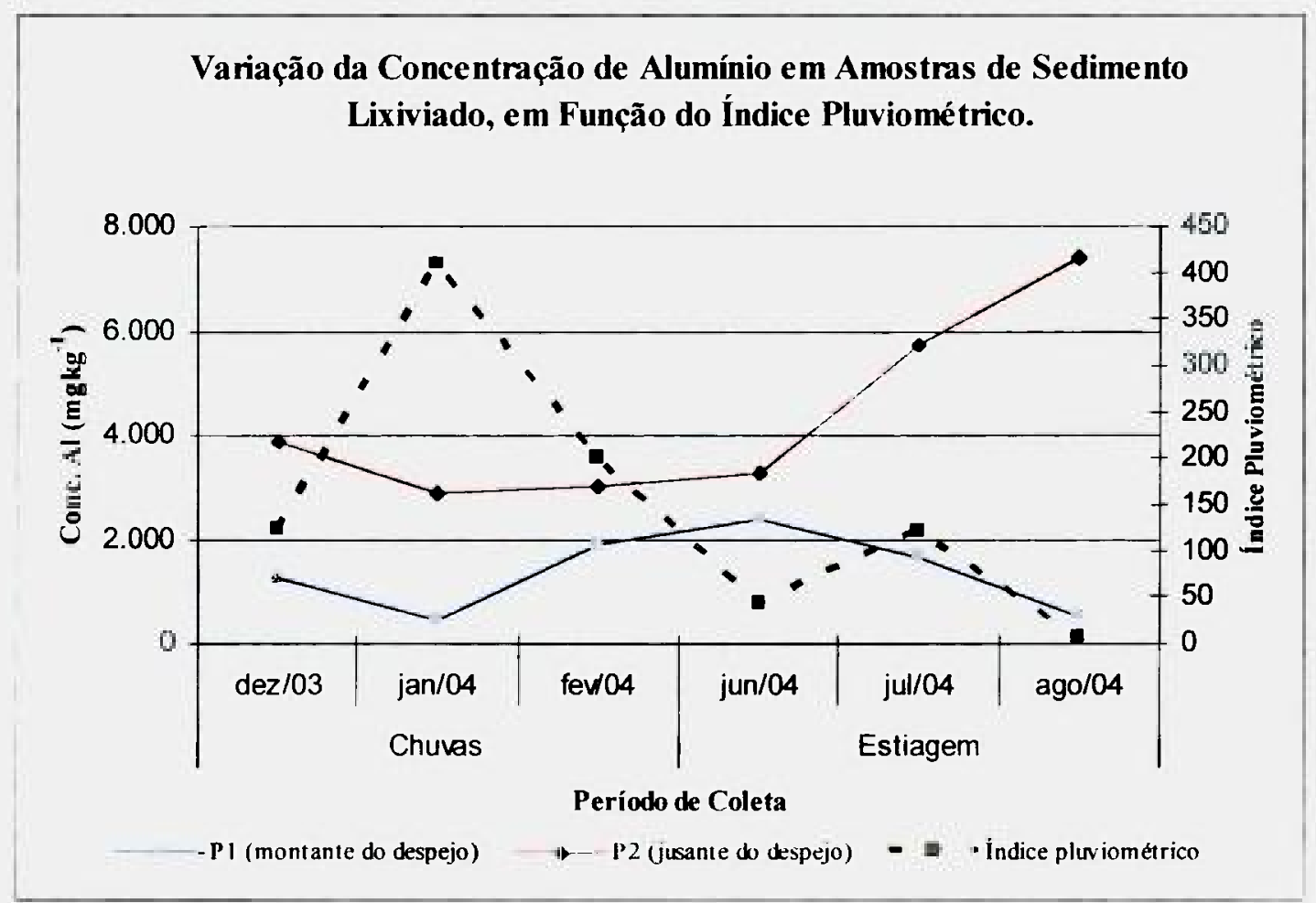

FIGURA 55 - Concentração de alumínio lixiviado em amostras de sedimento, conforme o indice pluviométrico e período de coleta. 
Relacionando-se as concentrações de alumínio obtidas no sedimento lixiviado em P1 e P2, com a média mensal da quantidade de sulfato de alumínio adicionado como coagulante pela ETA de Registro, observa-se o potencial acumulador do lodo de ETA próximo ao local do despejo.

As medidas de alumínio encontradas em Pl apontam um nivel de background do elemento na região, que varia ao longo do ciclo hídrico e mostrando uma tendência de incremento para níveis próximos de $2.000 \mathrm{mg} \cdot \mathrm{kg}^{-1}$ no período de estiagem. Contudo, estes valores são inferiores ao valor mínimo obtido para as medidas realizadas em P2. O perfil dos valores obtidos para o alumínio no ponto $\mathrm{P} 2$ evidencia os efeitos diretos do despejo da ETA no sedimento de fundo, além da maneira como o ciclo hídrico pode influenciar na dispersão dos depósitos do lodo da ETA no sedimento localizado próximo ao despejo, no curso d'água receptor (FIG.55 e 56).

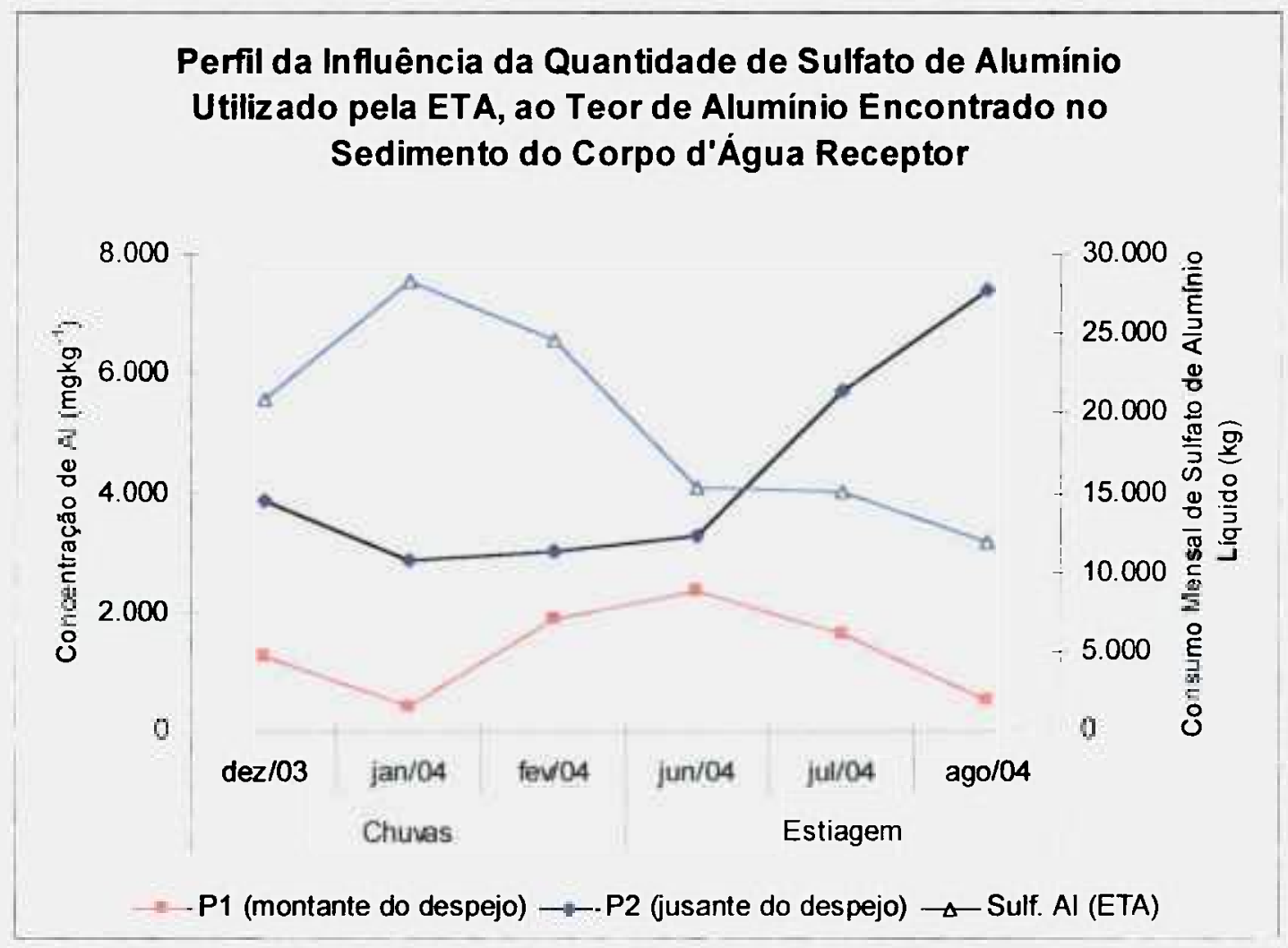

FIGURA 56 - Correlação do teor de aluminio encontrado nas amostras de sedimento com a quantidade de coagulante adicionado pela ETA. 
Ainda que quantidades maiores do coagulante sejam adicionadas para tratamento da água bruta da ETA no período de chuvas (Dezembro/03 a Fevereiro/04), especialmente em consequiência do aumento da turbidez, nota-se um maior carreamento do lodo depositado no rio Sem Nome em razão do alto índice pluviométrico neste periodo.

Índices pluviométricos menores (como o verificado em agosto de 2004) contribuem para um menor arraste do lodo depositado e, portanto, para o aumento na concentração do aluminio no sedimento do rio, mesmo quando a quantidade do coagulante adicionado é equivalente a menos da metade da quantidade adicionada, considerando-se a média para o mês de dezembro de 2003.

Portanto, os resultados obtidos para as amostras de sedimento lixiviado mostram que as amostras de sedimento recolhidas nos cursos d'água no entorno da ETA indicam a presença de alumínio proveniente diretamente do descarte de lodo da ETA, no ponto de amostragem localizado à jusante do descarte do lodo pela ETA de Registro.

Apesar da concentração média de alumínio apresentar valores inferiores a 58.030 mg.kg ${ }^{-1}$ pelo valor-guia de PEL, conforme CCME (1999), a diferença de $1.000 \mathrm{mg} . \mathrm{kg}^{-1}$ observada entre os niveis de background natural e do detectado em função do descarte do lodo, representa por si só a capacidade potencial de deposição e contaminação do lodo da ETA, em função da projeção do descarte contínuo dos rejeitos da ETA.

\subsubsection{Avaliação estatística dos resultados de sedimentos por análise de correlação}

Nas TAB. 59 e 60 estão listados os coeficientes de correlação obtidos por meio das concentrações dos analitos determinados na fração lixiviável do sedimento recolhido nos diferentes pontos de coleta, 1 dia após o descarte de lodo da ETA. Para a correlação dos pontos de coletas avaliados na estação de chuvas (Dez./2003-Jan./2004) e estiagem (Jun./2004 a Ago./2004), foram considerados os resultados obtidos para os elementos $\mathrm{Na}$, $\mathrm{Mg}, \mathrm{P}, \mathrm{K}, \mathrm{Ca}, \mathrm{Fe}, \mathrm{Ba}, \mathrm{Co}, \mathrm{Al}, \mathrm{V}, \mathrm{Cr}, \mathrm{Mn}, \mathrm{Ni}, \mathrm{Cu}, \mathrm{Zn}, \mathrm{Cd}$ e Pb. 
TABELA 59 - Coeficientes de correlação para os pontos de coletas, considerando os elementos analisados nas amostras de sedimento no período de chuvas.

\begin{tabular}{|c|c|c|c|c|c|c|}
\hline & P1 & P2 & P3 & P4 & P5 & P6 \\
\hline P1 & 1,00 & & & & & \\
\hline P2 & 0,57 & 1,00 & & & & \\
\hline P3 & 0,69 & 0,91 & 1,00 & & & \\
\hline P4 & 0,60 & 0,95 & 0,99 & 1,00 & & \\
\hline P5 & 0,71 & 0,86 & 0,99 & 0,96 & 1,00 & \\
\hline P6 & 0,86 & 0,86 & 0,94 & 0,90 & 0,94 & 1,00 \\
\hline
\end{tabular}

TABELA 60 - Coeficientes de correlação para os pontos de coletas, para os elementos analisados nas amostras de sedimento no período de estiagem.

\begin{tabular}{|c|c|c|c|c|c|c|}
\hline & P1 & P2 & P3 & P4 & P5 & P6 \\
\hline P1 & 1,00 & & & & & \\
\hline P2 & 0,74 & 1,00 & & & & \\
\hline P3 & 0,86 & 0,80 & 1,00 & & & \\
\hline P4 & 0,89 & 0,81 & 1,00 & 1,00 & & \\
\hline P5 & 0,88 & 0,78 & 0,98 & 0,98 & 1,00 & \\
\hline P6 & 0,88 & 0,78 & 0,99 & 0,99 & 1,00 & 1,00 \\
\hline
\end{tabular}

Os resultados médios obtidos mostram uma forte correlação entre os pontos de coleta nos dois periodos estudados, especialmente entre os pontos de coleta P3, P4, P5 e P6, de acordo com os elementos considerados, para ambos os períodos de chuvas e estiagem. Este fato pode ser explicado em razão da própria geologia da região, uma vez que os pontos estão situados em corpos d'água diferentes.

A correlação média observada entre o ponto $\mathrm{Pl}$ e os demais pontos na TAB.59, pode ser explicada como consequência de uma maior influência do intemperismo no carreamento de substâncias em um bairro caracterizado por ocupações irregulares.

Em relação ao ponto $\mathrm{P} 2$ foi observado uma correlação menor, provavelmente associada à variação do teor de alumínio proveniente do descarte, já que nas análises de sedimento representou o único elemento analisado com concentrações maiores em P2. 


\subsection{Análise da comunidade bentônica}

A influência do lançamento do lodo da ETA também foi avaliada por meio da macrofauna bentônica analisada. As análises foram realizadas pelos laboratórios do Departamento de Saúde Ambiental, da Faculdade de Saúde Pública da Universidade de São Paulo. Foram realizadas seis amostragens nos pontos de coleta (PI a P6) durante um periodo de três meses, onde a cada mês realizaram-se duas coletas, uma anterior e outra posterior ao descarte de lodo pela ETA. Para cada ponto de coleta foram realizadas coletas idênticas para as análises qualitativas e quantitativas dos bentônicos, recolhendo-se aproximadamente $500 \mathrm{~g}$ de sedimento de fundo.

As análises quantitativas foram realizadas com exame sob microscópio estereoscópico e estão descritas no apêndice. Uma relação de organismos encontrados e sua presença ou ausência em cada ponto de amostragem são apresentados na TAB.61. Os resultados relacionados à densidade numérica dos microorganismos também estão relacionados no apêndice. Os dados obtidos demonstram que ocorre uma pequena diferença de organismos encontrados entre o ponto 01 (montante da ETA) e os demais pontos de amostragem, a jusante da ETA.

TABELA 61 - Composição da comunidade bentônica nas estações de amostragem, em amostras de sedimentos.

\begin{tabular}{|c|c|c|c|c|c|c|}
\hline & \multicolumn{6}{|c|}{ Identificação dos pontos de amostragem } \\
\hline & P1 & P2 & P3 & P4 & P5 & P6 \\
\hline *Mollusca-Gastropoda & + & - & + & + & - & - \\
\hline Mollusca-Pelecypoda & + & - & - & - & - & - \\
\hline Insecta-Diptera- Chironomidae & + & + & - & + & + & + \\
\hline Insecta-Diptera-Ceratopogonidae & - & - & - & - & - & + \\
\hline Insecta-Ephemeroptera & - & - & - & - & + & + \\
\hline Annelida-Oligochaeta-Tubificidae & + & - & - & + & + & + \\
\hline Annelida-Hirudinea & + & + & - & - & - & - \\
\hline Total & 5 & 2 & 1 & 3 & 3 & 4 \\
\hline
\end{tabular}

(+) Presença

(-) Ausência 
O ponto 01 apresentou uma concentração elevada da familia Chironomidae no mês de setembro ( $>800$ organismos. $\mathrm{m}^{-3}$ ). Este resultado pode ser explicado em razão da maior quantidade de alimentos (matéria orgânica) advindo de descargas de esgoto doméstico observadas no local (Joasson, 1969).

Hirabayashi (2004) relata que pode ocorrer uma correlação entre a eutrofização e a dominância da família Chironomidae. Por outro lado, os pontos 02, 03 e 04 apresentaram uma menor diversidade e densidade numérica de organismos. Apesar de receberem contribuição direta do ponto 01 e da própria ETA, foi observado nos pontos 02 e 04 um substrato que apresentou uma fauna bentônica pouco influenciada pelos despejos de esgotos observados no ponto 1 e, principalmente, pelo despejo do lodo da ETA (Rocha, 1999).

Em relação aos pontos de coleta anteriores, os pontos 05 e 06 apresentaram uma maior diversidade com alguns organismos considerados de águas limpas, como por exemplo, a família Ephemeroptera, possivelmente porque ambos os pontos estão localizados no rio Ribeira de Iguape, que é um rio classificado como Classe 2 (CETESB, 2005). Deve ser ressaltado que apesar do ponto 06 estar localizado após o deságüe do rio Sem Nome no rio Ribeira de Iguape, não foi observada nenhuma diferença significativa na macrofauna bentônica em relação ao ponto 05 . Em razão da semelhança observada entre estes pontos, pode-se admitir a ocorrência de um processo de autodepuração natural ao longo do próprio rio Sem Nome, em razão do impacto pouco significativo do descarte do lodo da ETA no corpo d'água receptor.

Ao se considerar a macrofauna bentônica em sua totalidade, evidenciou-se a presença dos grupos Oligochaeta-Tubificidae e Diptera-Chironomidae entre os seis pontos de amostragem, durante o período de estudo. No entanto, apesar dos grupos Chironomidae (Diptera) e Annelida-Oligochaeta (vermes segmentados) serem considerados indicadores de água poluída (Rocha, 1999; Brinkhurst, 1974), são também organismos que se alimentam de material em decomposição e que apresentam preferência por sedimentos moles (Pennak, 1953), caracteristicos da região. 
Na FIG.57 é mostrado o resultado das análises de agrupamento no sedimento de fundo recolhido nas estações de coleta no período de estudo, considerando-se os dados obtidos na TAB.61. Os pontos de coleta P1, P4, P3 e P6 apresentam uma similaridade entre si, com um grau de discordância de aproximadamente 0,28 , mostrando que a comunidade bentônica foi semelhante nestes pontos de coleta.

Diagrama - Pontos de Coleta

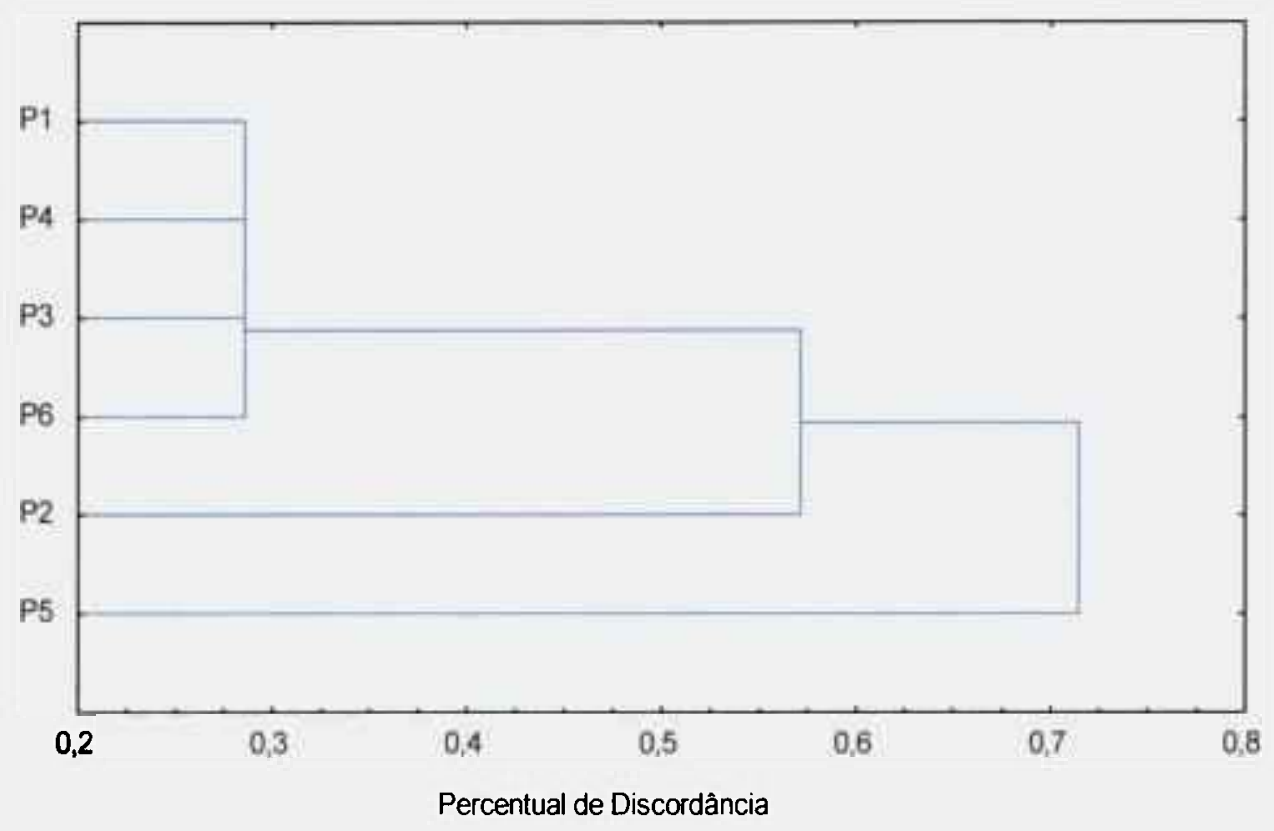

FIGURA 57 - Dendograma de discordância dos organismos bentônicos presentes no sedimento de fundo nos pontos de coleta Pl a P6.

$\mathrm{O}$ ponto de coleta $\mathrm{P} 2$ apresentou um grau de discordância maior em relação aos pontos P1, P4, P3 e P6. Apesar do ponto de coleta em questão estar diretamente sujeito à influência do descarte do lodo da ETA, também se deve considerar o fato de que o volume do efluente descartado pode contribuir para um maior carreamento do sedimento de fundo presente e, portanto, de parte da comunidade bentônica associada. O grau de discordância maior obtido no ponto P5 demonstra que a comunidade bentônica associada apresenta uma distribuição diferente dos demais pontos, especialmente por estar localizado a montante da confluência do rio Sem Nome. 
6.12 Considerações sobre tratamento e disposição de lodo de ETA em cidades de pequeno e médio porte

Foi mostrado que a composição química do lodo de ETA é variável, dependendo das características do copo d'água, dos produtos químicos utilizados na ETA e do próprio processo de tratamento. Foi observado também que o lodo possui características mais similares ao solo e da água de captação da região.

Foram discutidas as principais práticas de disposição de lodo, a necessidade da interrupção do lançamento de resíduos nos corpos d’água bem como do aprimoramento o processo de gestão da ETA e da necessidade do desenvolvimento de tecnologia integradas. $\mathrm{Na}$ TAB.62, a seguir, é apresentado um resumo de todos os processos alternativos possíveis de serem aplicados nas principais práticas de disposição de lodo de ETA.

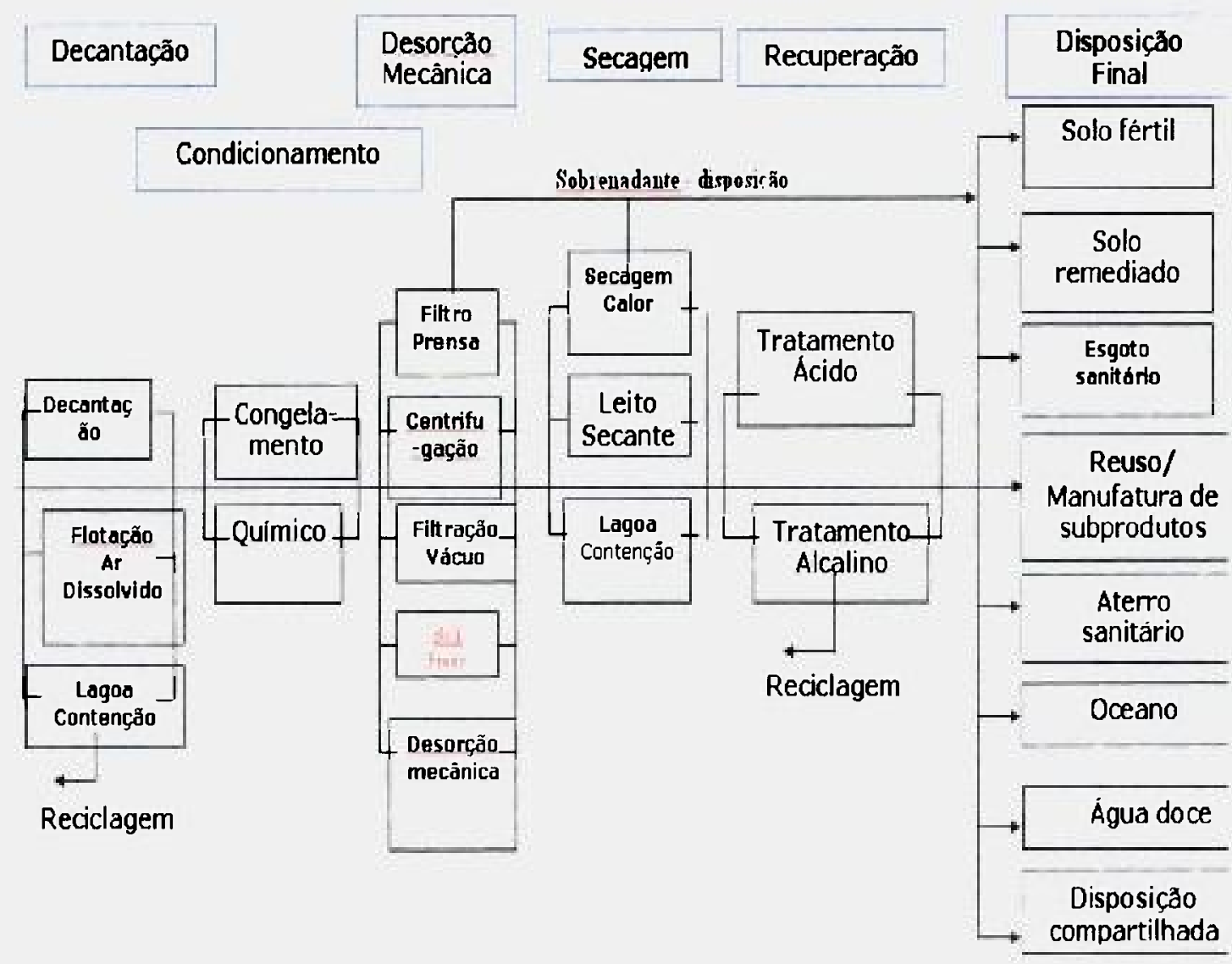

TABELA 62. Processos alternativos para o gerenciamento de lodo de ETAs. 
Os processos de disposição de lodos de ETAs mais comuns no país, além do descarte em corpos d'água estudado neste trabalho, são o acondicionamento do efluente em aterros e o descarte no sistema de esgotos. Um dos maiores problemas do acondicionamento dos lodos é o fato da maioria das ETAs no Brasil utilizarem de sistemas convencionais de ciclo completo, que são constituídos de uma etapa de decantação após a floculação, necessitando de processos para a concentração do lodo formado, para sua disposição final.

A abordagem do tema em diversos trabalhos publicados mostra que não há ainda uma solução única que responda satisfatoriamente ao problema, especialmente porque a composição do lodo formado por uma ETA é influenciada por fatores característicos da região onde se encontra a própria ETA. 


\section{CONCLUSÕES}

De acordo com os resultados obtidos dos diferentes tópicos abordados neste trabalho e listados, a seguir, pode-se concluir que:

\section{Caracterização do Lodo Gerado da ETA}

- A composição química média do lodo apresentou silício, alumínio e ferro como elementos majoritários, além da presença em níveis de traços de alguns metais tóxicos como o cromo, cobre, chumbo e zinco;

- Algumas propriedades físico-químicas das amostras de lodo recolhido dos decantadores permaneceram inalteradas ao longo do estudo, mesmo em períodos sazonais diferentes;

- Os valores médios resultantes da análise do lodo nas frações total, parcial e lixiviável mostraram que os elementos $\mathrm{Al}, \mathrm{Ca}, \mathrm{Mn}, \mathrm{P}$ e Cu são facilmente extraíveis, demonstrando uma forte disponibilidade ao ambiente, quando se consideram níveis de lixiviação acima de $50 \%$ do teor total encontrado. Por outro lado, elementos como Na, e K apresentaram baixa disponibilidade indicando provável associação desses elementos à matriz silicato;

- Os resultados encontrados nas amostras de lodo também mostraram especificamente os elementos $\mathrm{Al}$ e $\mathrm{Cu}$ como parâmetros importantes para a avaliação de contaminação de áreas próximas ao despejo de lodo por uma ETA;

2. Avaliação do Impacto do Descarte do Lodo da ETA no Curso d'Água

- Os resultados obtidos no estudo da fração solúvel do processo de tratamento de água da ETA de Registro mostraram elevados níveis de concentração dos elementos $\mathrm{Ca}$, $\mathrm{Mn}, \mathrm{Mg}, \mathrm{K}$ e $\mathrm{Na}$ durante as primeiras três horas do processo de descarte, além de alterações na qualidade das águas superficiais do corpo d'água receptor para uma distância de até 50 m do local do descarte da ETA; 
- O manganês foi identificado como um elemento característico do despejo e pode ser utilizado como elemento traçador do lodo descartado por apresentar-se no efluente em níveis superiores aos característicos da região e da legislação vigente. A presença de manganês no coagulante da ETA pode explicar sua presença no efluente da ETA;

- Constatou-se que a diluição durante a operação de descarte, decorrente do processo de lavagem do tanque de decantação, é um parâmetro importante a ser considerado no levantamento de alternativas para o destino do lodo;

- Os resultados demonstraram que o despejo do lodo não atende a legislação vigente (Decreto - Lei 8468/76, artigo 18; e artigo 19A), especialmente em razão do teor de sólidos e manganês. $\mathrm{O}$ alto teor de sólidos encontrado durante o início do processo de descarte pode promover lentamente um assoreamento do curso d'água, como mostra o depósito de lodo já existente no corpo d'água próximo ao local de lançamento;

- A maioria dos elementos analisados não apresentou evidências de contaminação nas águas superficiais dos cursos d'água estudados, quando comparadas às medidas realizadas a montante e a jusante do descarte do lodo pela ETA, em um período de até 1 dia após o descarte. A presença de alumínio em teores acima do estabelecido pela legislação foi associada a caracteristicas naturais da geologia da região, pois as coletas realizadas a montante do despejo da ETA também apresentaram estas características e também porque medidas realizadas para o monitoramento da qualidade de águas superficiais no estado de São Paulo pela CETESB mostram que o alumínio representa o parâmetro com mais não conformidades, associado principalmente à constituição do solo do estado;

- $\quad$ Elementos como Co, B, V, Cr, Ni, Cu, Mo, $\mathrm{Zn}, \mathrm{Sn}, \mathrm{Ag}$ e Cd apresentaram níveis de concentração abaixo do limite de quantificação tanto para as amostras de água superficial quanto para o monitoramento realizado no despejo, demonstrando que os niveis de metais tóxicos dissolvidos encontrados ao longo do corpo receptor, após o descarte do lodo, encontram-se abaixo dos limites definidos pela Resolução CONAMA, para cursos de água Classe 2; 
- Em relação aos organismos bentônicos, pode-se admitir que existe uma indicação de que grupos observados como típicos do ambiente com poluição orgânica e do próprio tipo de sedimento característico da região (mole e lodoso), não foram diretamente afetados pelo despejo do lodo da ETA.

\section{Avaliação Estatística}

- A avaliação estatística por dendogramas e Box-plot, dos principais parâmetros físico-químicos em amostras de águas superficiais mostrou que os parâmetros utilizados foram adequados para caracterizar os diferentes locais de amostragens, em função da similaridade química evidenciada para pontos de coleta situados em um mesmo curso d'água. A análise de Cluster demonstrou na prática uma similaridade entre os pontos de coleta ao longo de todo o período de estudo, com a ausência de contaminações aparentes do despejo da ETA, para as condições avaliadas.

\section{Considerações Finais e Trabalhos Futuros}

O descarte do lodo de ETA afeta o meio ambiente local em razão dos niveis de alumínio encontrados em amostras de sedimento lixiviado no ponto de coleta logo após o descarte do lodo da ETA. Apesar dos níveis encontrados para este elemento serem inferiores aos níveis de referência PEL, deve-se considerar os efeitos em longo prazo do descarte sistemático dos residuos da ETA no meio ambiente local.

Embora os resultados obtidos não demonstrem uma contaminação direta, devemos observar que no periodo anterior a 1996 não havia exigência dos órgãos ambientais para tratar estes lodos. Após esta data, houve um prazo para que as empresas regularizassem seus efluentes, de modo que programas que visem enquadrar os lançamentos de lodo de ETA às legislações vigentes devem ser implantados para colaborar com a proteção dos cursos d'água. 
Em se tratando de ETAs localizadas em cidades de médio porte, com uma população superior a 50.000 habitantes e inferior a 250.000 habitantes, como a cidade de Registro com 56.214 habitantes, e especialmente para cidades de pequeno porte, com menos de 50.000 habitantes (Brasil, 2004; IBGE, 2004), pode haver uma dificuldade na implantação das técnicas de adensamento de lodo em razão da necessidade de se manter equipes técnicas para a operação e manutenção deste equipamentos.

Em uma avaliação preliminar, concluiu-se neste estudo que a mais provável forma de disposição desses resíduos para a ETA estudada seria para o sistema de esgotos municipal, para um destino final em conjunto com o lodo formado pela ETE local. A implantação deste sistema minimizaria o custo de transporte para a disposição dos resíduos da ETA, além de centralizar o gerenciamento do resíduo formado. Alguns trabalhos citados neste estudo mostram que não há interferência significativa no desempenho da ETE, havendo somente a necessidade de adaptação da capacidade da rede coletora para o recebimento do efluente da ETA. Apesar de legislações que regem o problema serem cada vez mais rigorosas, exigindo soluções mais eficientes, a adoção de técnicas de disposição de lodos deve se mostrar realista quanto à especificidade dos problemas técnicos e econômicos da cada ETA.

Deste modo, sugere-se também por parte das empresas de saneamento, a adoção de políticas específicas de gerenciamento de lodo de ETA, estabelecendo-se medidas oficiais de controle e disposição destes residuos, por meio da regulamentação de alternativas jả testadas e tidas como viáveis para a resolução do problema. Diversos trabalhos já foram realizados sobre o tema sem que, no entanto, se adotasse estes estudos como prova técnica de que representam alternativas efetivamente viáveis para a resolução do problema. Cabe aos órgãos técnicos competentes a aplicação destas técnicas em programas de reaproveitamento e tratamento do lodo de ETA. 
APÊNDICE A - Concentração média de metais em água bruta, obtida a jusante da ETA, relacionada com os dados obtidos pelo estudo de duas bacias hidrográficas no Estado de São Paulo (Lemes, 2001).

\begin{tabular}{|c|c|c|c|}
\hline Elemento & Local & $\begin{array}{c}\text { Concentração } \\
\text { Média } \\
\left(\mathrm{mg.L} \mathrm{L}^{-1}\right) \\
\end{array}$ & $\begin{array}{c}\text { Faixa de } \\
\text { Concentração } \\
\left(\mathrm{mg}^{\left.-\mathrm{L}^{-1}\right)}\right. \\
\end{array}$ \\
\hline \multirow{3}{*}{ Alumínio } & Jusante (ETA de Registro) & 0.163 & $0.028-0.307$ \\
\hline & Bacia do rio Pardo & 0,154 & $<0,092-0,578$ \\
\hline & Bacia do rio Mogi-Guaçu & 0,133 & $<0,092-0,578$ \\
\hline \multirow{3}{*}{ Bário } & Jusante (ETA de Registro) & 0,051 & $0,040-0,059$ \\
\hline & Bacia do rio Pardo & 0,071 & $0,011-0,180$ \\
\hline & Bacia do rio Mogi-Guaçu & 0,073 & $0,012-0,151$ \\
\hline \multirow{3}{*}{ Cádmio } & Jusante (ETA de Registro) & 0,004 & $0,001-0,010$ \\
\hline & Bacia do rio Pardo & $<0,004$ & - \\
\hline & Bacia do rio Mogi-Guaçu & $<0,004$ & - \\
\hline \multirow{3}{*}{ Cromo } & Jusante (ETA de Registro) & 0,017 & $0,004-0,030$ \\
\hline & Bacia do rio Pardo & $<0,004$ & - \\
\hline & Bacia do rio Mogi-Guaçu & $<0,004$ & - \\
\hline \multirow{3}{*}{ Cobalto } & Jusante (ETA de Registro) & 0,010 & $0,005-0,014$ \\
\hline & Bacia do rio Pardo & 0,049 & $<0,017-0,095$ \\
\hline & Bacia do rio Mogi-Guaçu & 0,048 & $<0,017-0,095$ \\
\hline \multirow{3}{*}{ Cobre } & Jusante (ETA de Registro) & 0,004 & $0,003-0,005$ \\
\hline & Bacia do rio Pardo & 0,0099 & $<0,003-0,020$ \\
\hline & Bacia do rio Mogi-Guaçu & 0,009 & $<0,003-0,020$ \\
\hline \multirow{3}{*}{ Ferro } & Jusante (ETA de Registro) & 3,602 & $2,164-5360$ \\
\hline & Bacia do rio Pardo & 1,114 & $0,042-3,396$ \\
\hline & Bacia do rio Mogi-Guaçu & 1,131 & $0,016-3,041$ \\
\hline \multirow{3}{*}{ Chumbo } & Jusante (ETA de Registro) & $<0,001$ & $<0,001$ \\
\hline & Bacia do rio Pardo & $<0,016$ & - \\
\hline & Bacia do rio Mogi-Guaqu & $<0,016$ & - \\
\hline \multirow{3}{*}{ Manganês } & Jusante (ETA de Registro) & 0,160 & $0,090-0,223$ \\
\hline & Bacia do rio Pardo & 0,062 & $0,006-0,228$ \\
\hline & Bacia do rio Mogi-Guaçu & 0,138 & $0,008-0,815$ \\
\hline \multirow{3}{*}{ Niquel } & Jusante (ETA de Registro) & 0,009 & $0,002-0,025$ \\
\hline & Bacia do rio Pardo & $<0,016$ & - \\
\hline & Bacia do rio Mogi-Guaçu & $<0,016$ & - \\
\hline \multirow{3}{*}{ Prata } & Jusante (ETA de Registro) & 0,007 & $0,002-0,012$ \\
\hline & Bacia do rio Pardo & 0,012 & $<0,001-0,028$ \\
\hline & Bacia do rio Mogi-Guaçu & 0,012 & $<0,001-0,027$ \\
\hline \multirow{3}{*}{ Zinco } & Jusante (ETA de Registro) & 0,052 & $0,005-0,193$ \\
\hline & Bacia do rio Pardo & $<0,003$ & - \\
\hline & Bacia do rio Mogi-Guaçu & $<0.003$ & - \\
\hline
\end{tabular}




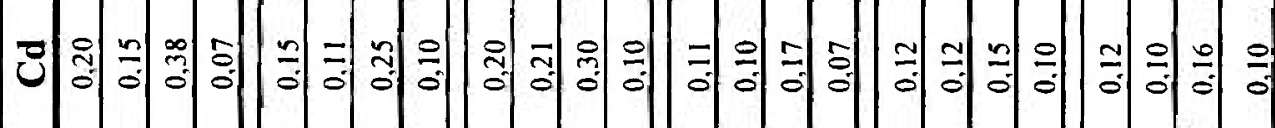

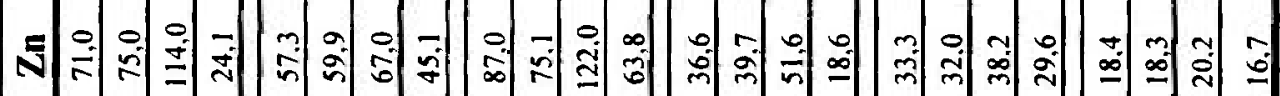

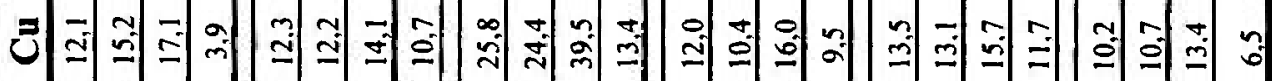

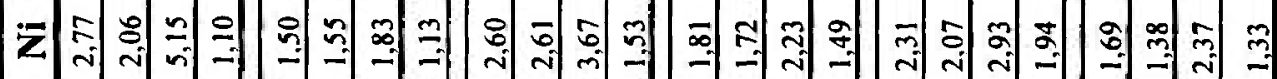

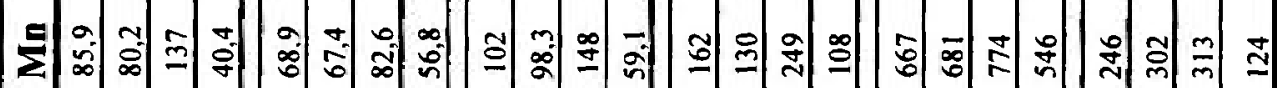

$\stackrel{8}{8}$

完

:

0

,

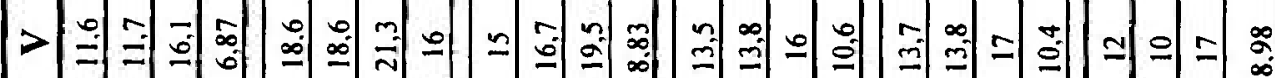

焉

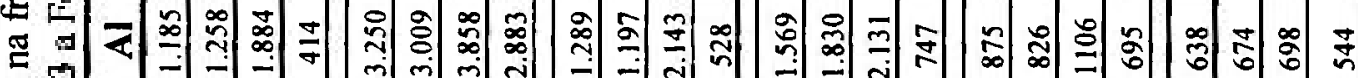

ठ 今

है

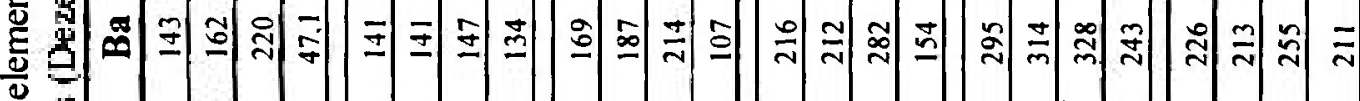

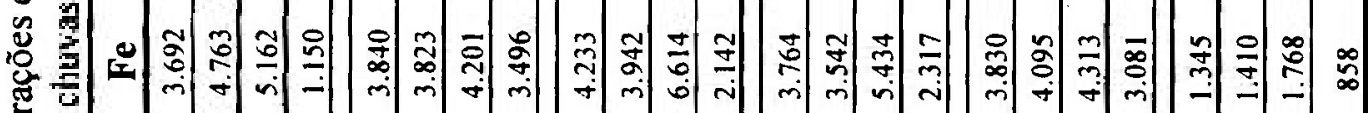

空

定

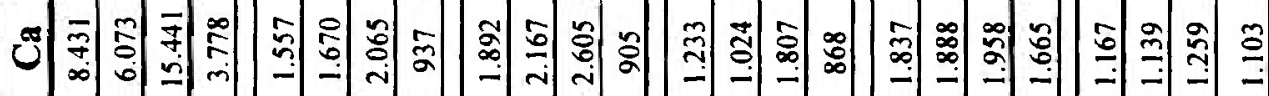

(

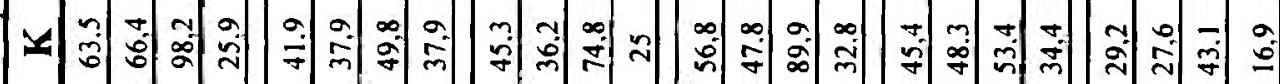

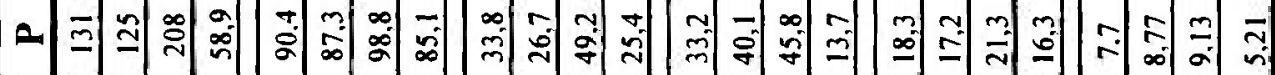

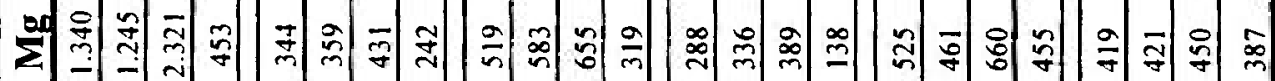

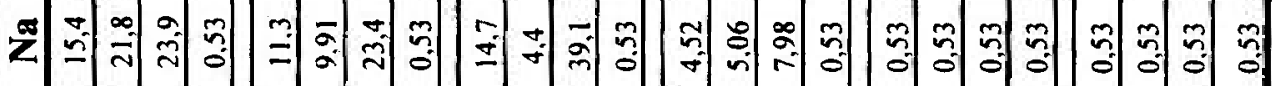

$\infty$

至 


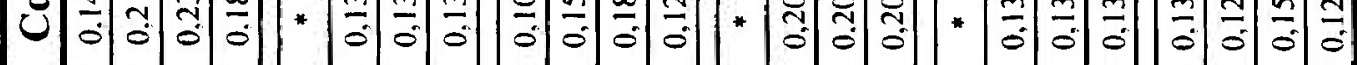

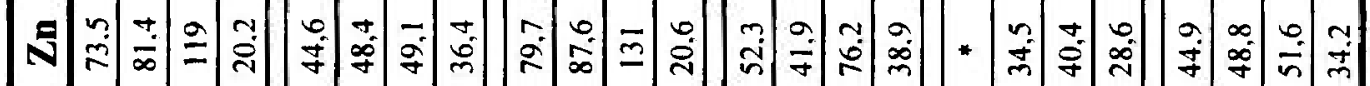

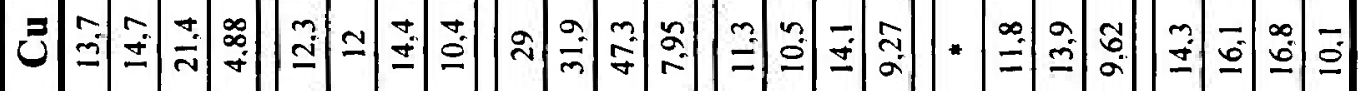

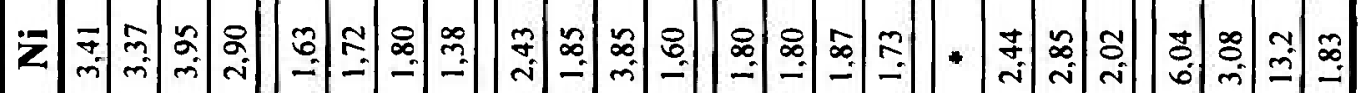

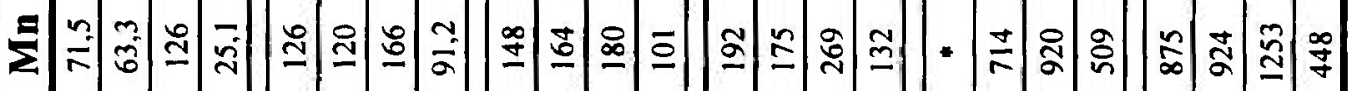
y $\sum_{2}$

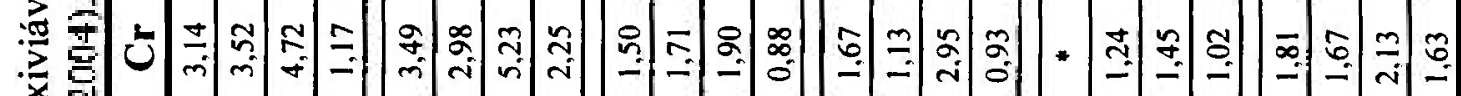

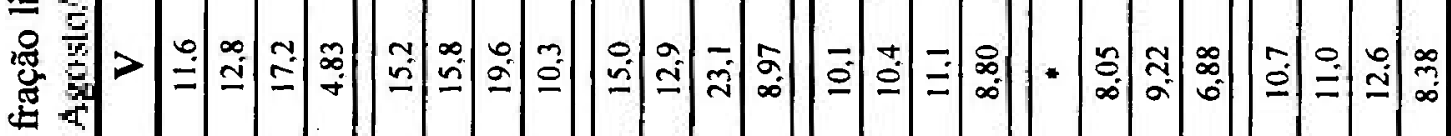

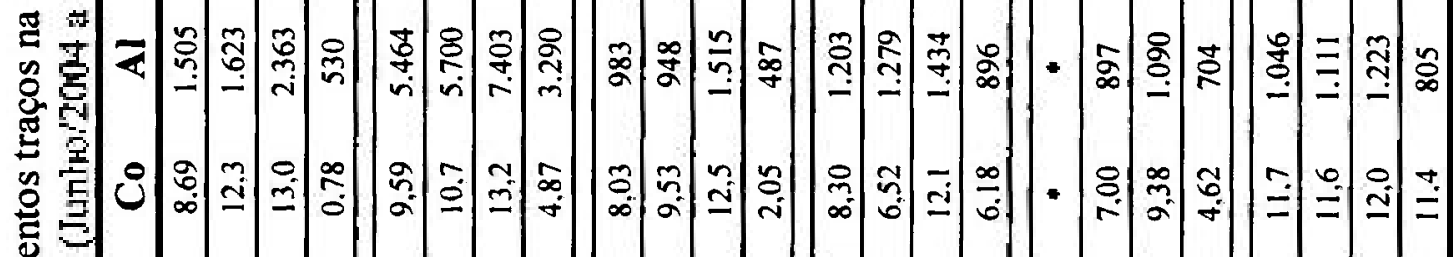

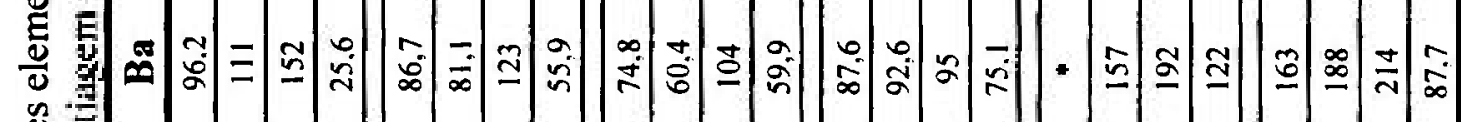
s.

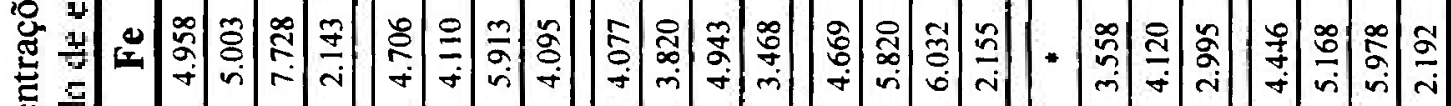
密

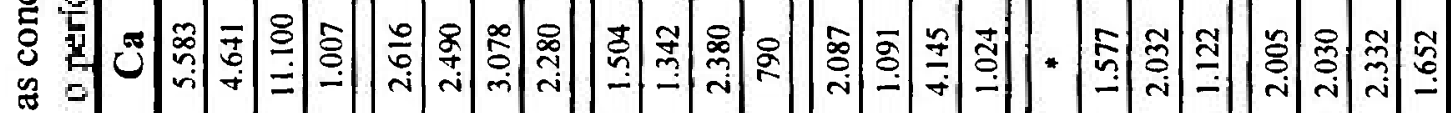
营

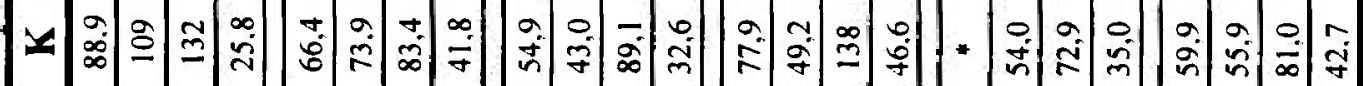

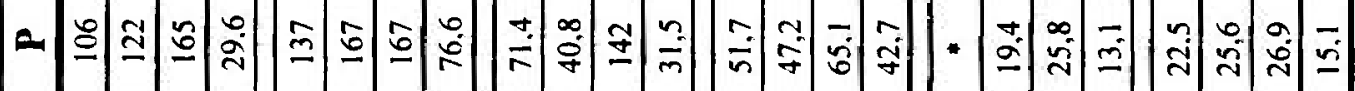

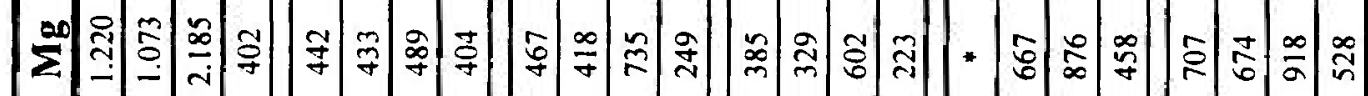

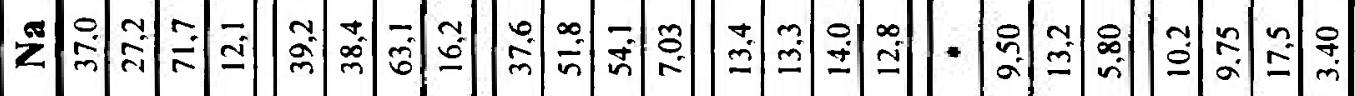
告

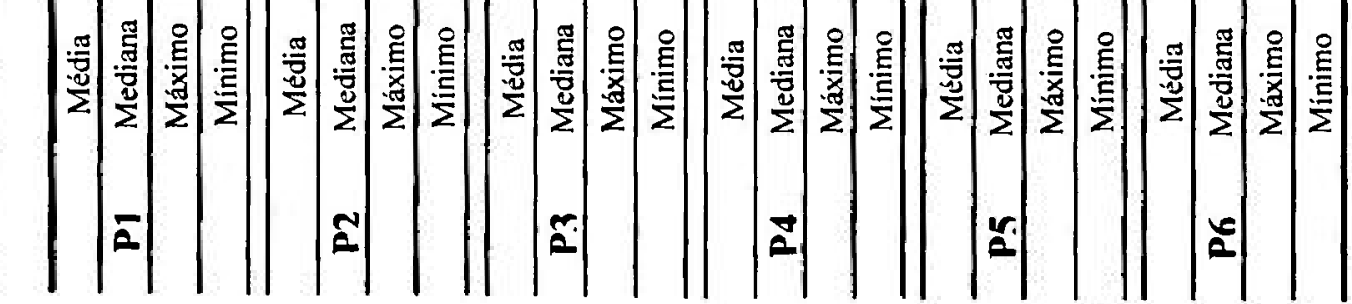


APÊNDICE D - Perfil do comportamento dos elementos analisados em amostras de sedimento coletadas 1 dia após o descarte do lodo da ETA, durante o período de chuvas (Dezembro/2003 a Fevereiro de 2004).
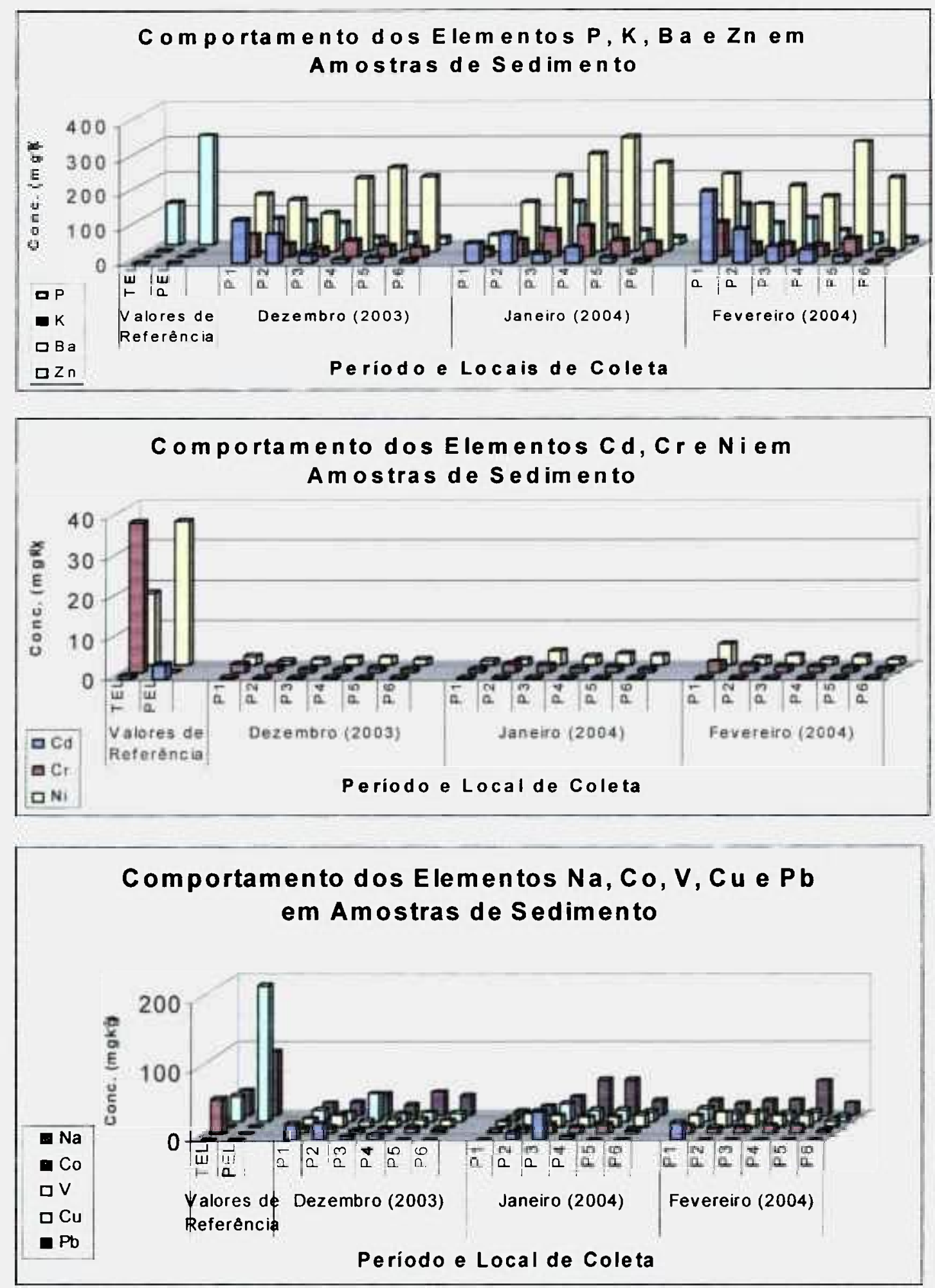
APÊNDICE E - Perfil do comportamento dos elementos analisados em amostras de sedimento coletadas 1 dia após o descarte do lodo da ETA, durante o período de chuvas (Dezembro/2003 a Fevereiro/2004).
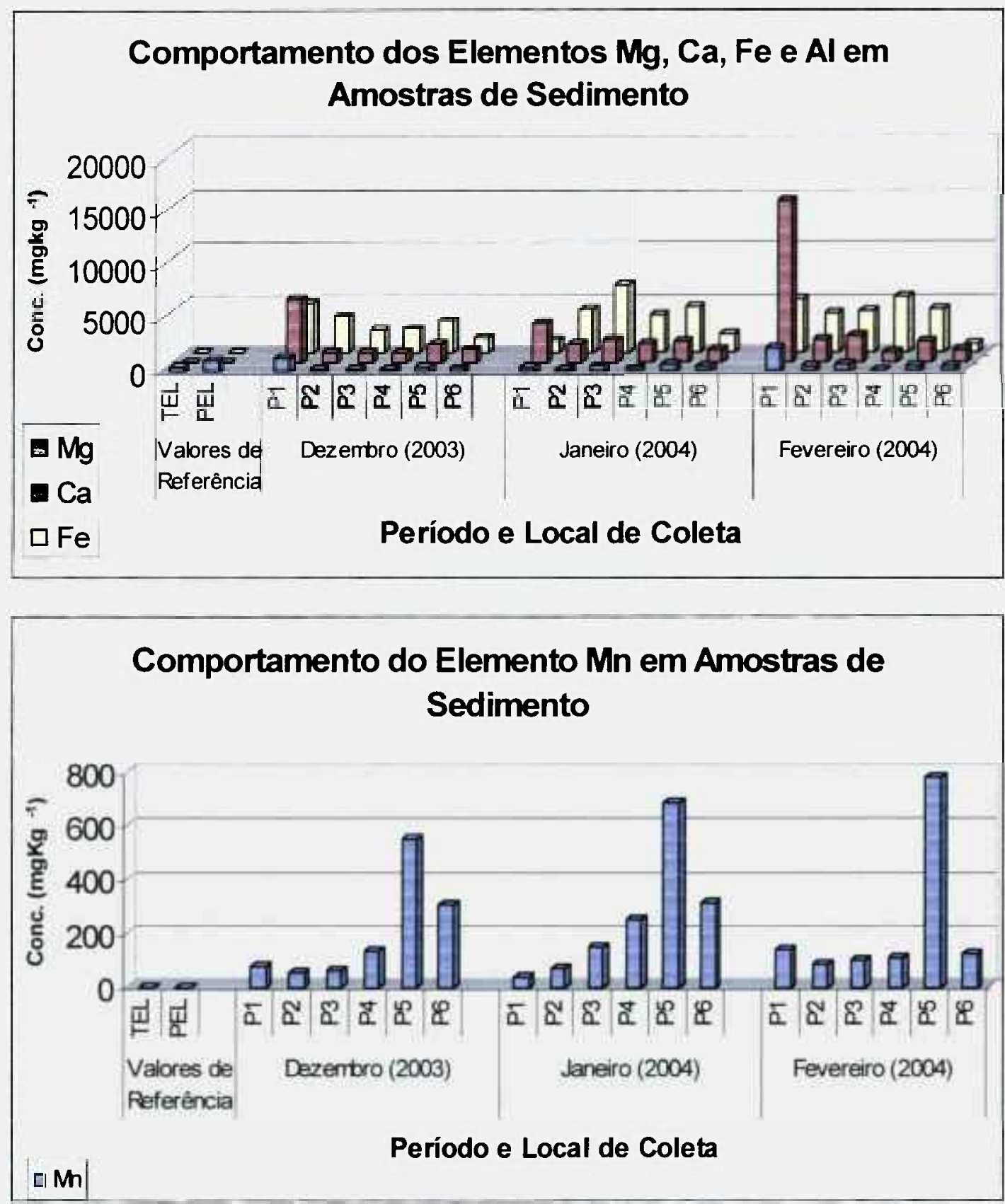
sedimento coletadas 1 dia após o descarte do lodo da ETA, durante o período de estiagem (Junho/2003 a Agosto/2004).
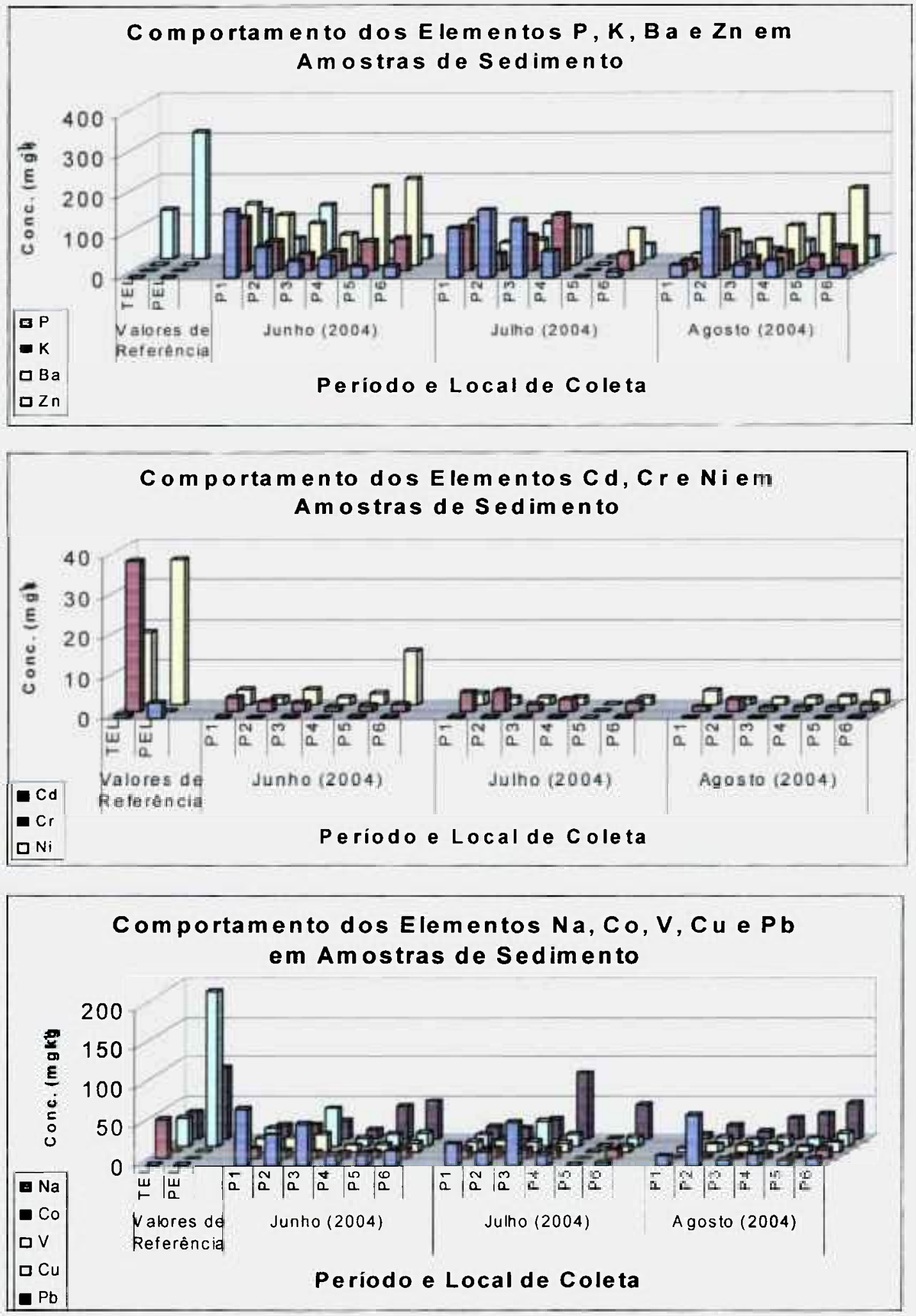
APÊNDICE G - Perfil do comportamento dos elementos analisados em amostras de sedimento coletadas 1 dia após o descarte do lodo da ETA, durante o período de estiagem (Junho/2003 a Agosto/2004).

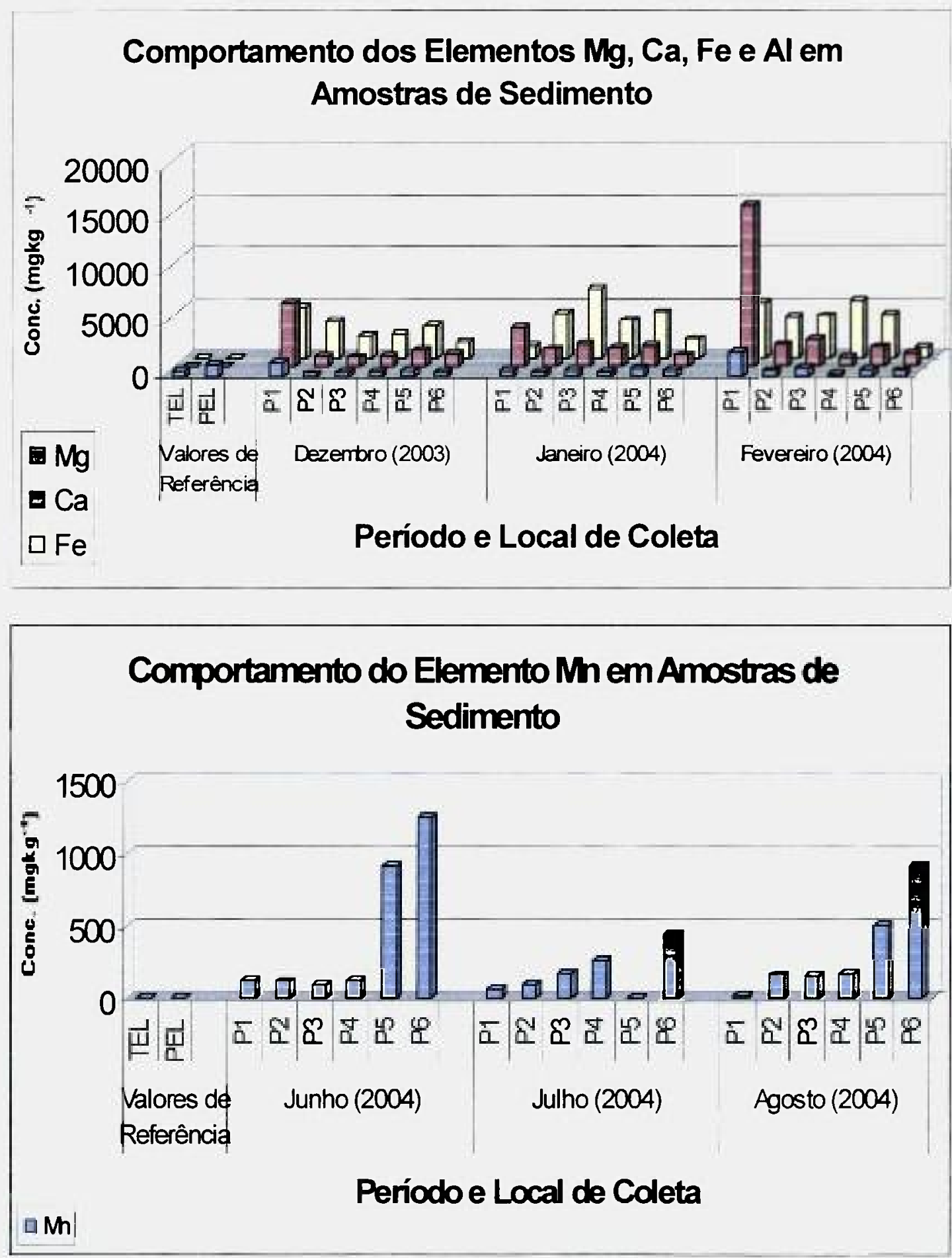


APÊNDICE $\mathrm{H}$ - Abundância relativa da comunidade bentônica no período de estudo, realizadas antes e depois do descarte de lodo da ETA.

\begin{tabular}{|c|c|c|c|c|c|c|}
\hline \multicolumn{7}{|c|}{ Contagem de Macroinvertebrados (em organismos. $\mathrm{m}^{-3}$ ) } \\
\hline \multirow{4}{*}{ Organismo } & \multicolumn{6}{|c|}{ Ponto 01 } \\
\hline & \multicolumn{2}{|c|}{$\mathrm{I}^{\mathrm{a}}$ Coleta } & \multicolumn{2}{|c|}{$2^{\mathrm{a}}$ Coleta } & \multicolumn{2}{|c|}{$3^{a}$ Coleta } \\
\hline & $\begin{array}{l}\text { Antes do } \\
\text { descarte }\end{array}$ & $\begin{array}{l}\text { Depois do } \\
\text { descarte }\end{array}$ & $\begin{array}{l}\text { Antes do } \\
\text { descarte }\end{array}$ & $\begin{array}{l}\text { Depois do } \\
\text { descarte }\end{array}$ & $\begin{array}{l}\text { Antes do } \\
\text { descarte }\end{array}$ & $\begin{array}{c}\text { Depois do } \\
\text { descarte }\end{array}$ \\
\hline & $21 / 9 / 2004$ & $23 / 9 / 2004$ & $20 / 10 / 2004$ & $22 / 10 / 2004$ & $5 / 4 / 2005$ & $7 / 4 / 2005$ \\
\hline Mollusca-Pelecypoda & 0 & 0 & 0 & 0 & 1 & 0 \\
\hline Insecta-Diptera-Chironomidac & 101 & 850 & 5 & 1 & 0 & 0 \\
\hline Annelida-Oligochaeta-Tubificidae & 3 & 0 & 0 & 0 & 0 & $\overline{0}$ \\
\hline Annelida-Hirudinea & 0 & 0 & 0 & 1 & 0 & 0 \\
\hline \multirow{4}{*}{ Organismo } & \multicolumn{6}{|c|}{ Ponto 02} \\
\hline & \multicolumn{2}{|c|}{$1 \cdot$ Coleta } & \multicolumn{2}{|c|}{$2^{2}$ Coleta } & \multicolumn{2}{|c|}{$3^{2}$ Coleta } \\
\hline & $\begin{array}{l}\text { Antes do } \\
\text { descarte }\end{array}$ & $\begin{array}{c}\text { Depois do } \\
\text { descarte }\end{array}$ & $\begin{array}{l}\text { Antes do } \\
\text { descarte }\end{array}$ & $\begin{array}{c}\text { Depois do } \\
\text { descante }\end{array}$ & $\begin{array}{l}\text { Antes do } \\
\text { descarte }\end{array}$ & $\begin{array}{c}\text { Depois do } \\
\text { descante }\end{array}$ \\
\hline & $21 / 9 / 2004$ & $23 / 9 / 2004$ & $20 / 10 / 2004$ & $22 / 10 / 2004$ & $5 / 4 / 2005$ & $7 / 4 / 2005$ \\
\hline Mollusca-Gastropoda & 1 & 3 & 0 & 0 & 0 & 0 \\
\hline \multirow[t]{5}{*}{ Annelida-Hirudinea } & 1 & 0 & $\overline{0}$ & $\overline{0}$ & 0 & $\overline{0}$ \\
\hline & \multicolumn{6}{|c|}{ Ponto 03} \\
\hline & \multicolumn{2}{|c|}{$1^{2}$ Coleta } & \multicolumn{2}{|c|}{$2^{2}$ Coleta } & \multicolumn{2}{|c|}{$3^{2}$ Coleta } \\
\hline & $\begin{array}{l}\text { Antes do } \\
\text { descante }\end{array}$ & $\begin{array}{c}\text { Depois do } \\
\text { descante }\end{array}$ & $\begin{array}{l}\text { Antes do } \\
\text { descane }\end{array}$ & $\begin{array}{c}\text { Depois do } \\
\text { descarte }\end{array}$ & $\begin{array}{l}\text { Antes do } \\
\text { descane }\end{array}$ & $\begin{array}{c}\text { Depois do } \\
\text { descarte }\end{array}$ \\
\hline & $21 / 9 / 2004$ & $23 / 9 / 2004$ & $20 / 10 / 2004$ & $22 / 10 / 2004$ & $5 / 4 / 2005$ & $7 / 4 / 2005$ \\
\hline \multirow[t]{5}{*}{ Mollusca-Gastropoda } & 1 & 0 & 7 & 0 & $*$ & $*$ \\
\hline & \multicolumn{6}{|c|}{ Ponto 04} \\
\hline & \multicolumn{2}{|c|}{$1^{2}$ Coleta } & \multicolumn{2}{|c|}{2 Coleta } & \multicolumn{2}{|c|}{$3^{\mathrm{a}}$ Coleta } \\
\hline & $\begin{array}{l}\text { Antes do } \\
\text { descarte }\end{array}$ & $\begin{array}{c}\text { Depois do } \\
\text { descarte }\end{array}$ & $\begin{array}{l}\text { Antes do } \\
\text { descarte }\end{array}$ & $\begin{array}{c}\text { Depois do } \\
\text { descarte }\end{array}$ & $\begin{array}{l}\text { Antes do } \\
\text { descante }\end{array}$ & $\begin{array}{c}\text { Depois do } \\
\text { descarte }\end{array}$ \\
\hline & $21 / 9 / 2004$ & $23 / 9 / 2004$ & $20 / 10 / 2004$ & $22 / 10 / 2004$ & $5 / 4 / 2005$ & $7 / 4 / 2005$ \\
\hline Mollusca-Gastropoda & 0 & 2 & 0 & 0 & 0 & 0 \\
\hline Insecta-Diptera-Chironomidae & 7 & 0 & 0 & 1 & 0 & 0 \\
\hline Annelida-Oligochaeta-Tubificidae & 9 & $\mathbf{0}$ & 0 & 0 & 0 & 0 \\
\hline \multirow{4}{*}{ Organismo } & \multicolumn{6}{|c|}{ Ponto 05 } \\
\hline & \multicolumn{2}{|c|}{$I^{a}$ Coleta } & \multicolumn{2}{|c|}{$2^{a}$ Coleta } & $3^{\mathrm{a} C}$ & oleta \\
\hline & $\begin{array}{l}\text { Antes do } \\
\text { descarte }\end{array}$ & $\begin{array}{l}\text { Depois do } \\
\text { descarte }\end{array}$ & $\begin{array}{l}\text { Antes do } \\
\text { descarte }\end{array}$ & $\begin{array}{l}\text { Depois do } \\
\text { descarte }\end{array}$ & $\begin{array}{l}\text { Antes do } \\
\text { descante }\end{array}$ & $\begin{array}{c}\text { Depois do } \\
\text { descarte }\end{array}$ \\
\hline & $21 / 9 / 2004$ & $23 / 9 / 2004$ & $20 / 10 / 2004$ & $22 / 10 / 2004$ & $5 / 4 / 2005$ & $7 / 4 / 2005$ \\
\hline Insecta-Diptera-Chironomidae & 2 & 0 & 0 & 0 & 0 & 0 \\
\hline Insecta-Ephemeroptera & 1 & 0 & 0 & 0 & 0 & 0 \\
\hline Annelida-Oligochaeta-Tubificidae & 5 & 4 & 3 & 0 & 0 & 0 \\
\hline & & & Pont & & & \\
\hline & $1^{8}$ & leta & $2^{2} \mathrm{C}$ & leta & $3^{\mathrm{a} C}$ & oleta \\
\hline Organismo & $\begin{array}{l}\text { Antes do } \\
\text { descarte }\end{array}$ & $\begin{array}{l}\text { Depois do } \\
\text { descarte }\end{array}$ & $\begin{array}{l}\text { Antes do } \\
\text { descante }\end{array}$ & $\begin{array}{c}\text { Depois do } \\
\text { descarte }\end{array}$ & $\begin{array}{l}\text { Antes do } \\
\text { descarte }\end{array}$ & $\begin{array}{c}\text { Depois do } \\
\text { descarte }\end{array}$ \\
\hline & $21 / 9 / 2004$ & $23 / 9 / 2004$ & $20 / 10 / 2004$ & $22 / 10 / 2004$ & $5 / 4 / 2005$ & $7 / 4 / 2005$ \\
\hline Insecta-Diptera-Chironomidae & 1 & 0 & 0 & 0 & 0 & 0 \\
\hline Insecta-Diptera-Ceratopogonidae & 0 & 2 & 0 & 0 & 0 & 0 \\
\hline Insecta-Ephemeroptera & 0 & 9 & 0 & 0 & 0 & 0 \\
\hline Annelida-Oligochaeta-Tubificidae & 2 & 2 & 0 & 0 & 0 & 0 \\
\hline
\end{tabular}




\section{REFERÊNCIAS BIBLIOGRÁFICAS}

1. ALBRECHT, A.E. Disposal of alum sludges. AWWA Journal. v. 64, n. 1, p. 46-72, 1972.

2. ALLOWAY, B.J.; AYRES, D.C. Chemical principles of environmental pollution, Glasgow: Chapman and Hall, 1994. p. 31-43.

3. AWWA - AMERICAN WATER WORKS ASSOCIATION JOURNAL, Processing water-treatment-plant sludge. Denver, USA, 1974.

4. AWWA - AMERICAN WATER WORKS ASSOCIATION JOURNAL, Processing Water-Treatment-Plant Sludge. Denver, USA, 1995.

5. ANDREOLI, C.V. Resíduos sólidos do saneamento: processamento, reciclagem e disposição final. Rio de Janeiro, R.J.: ABES, 2001.

6. APHA, AWWA, WEF. Standard methods for the examination of water and wastewater. $20^{\mathrm{a}}$ ed. Washington: American Public Health Association. 1998.

7. ABNT - ASSOCIAÇÃO BRASILEIRA DE NORMAS TÉCNICAS. Resíduos Sólidos: classificação. Rio de Janeiro: ABNT, 2004 (a). (NBR 10.004).

8. BARON, J.S.; POFF, N.L.; ANGERMEIER, P.L.; DAHM, C.N.; GLEICK, P.H.; HAIRTON, R.B.; JACKSON, C.A.; RICHTER, B.D.; STEINMAN, A.D. Meeting ecological and societal needs for freshwater. Ecological Applications, v. 12, p. 1247-1260, 2002.

9. BARROSO, M.M. Problemática dos metais e sólidos no tratamento de água (estação convencional de ciclo completo) e nos resíduos gerados. 2002. Dissertação (Mestrado) - Escola de Engenharia de São Carlos, São Carlos.

10. BRANDIMARTE, A.L.; ANAYA, A. Botton fauna flotation using a solution of sodium chloride. Verhandlung Internationale Vereingung de Limnologie, v. 26, p. 23582359, 1998. 
11. BRASIL. CONSTITUIÇÃO DA REPÚBLICA FEDERATIVA DO BRASIL, Brasília, Senado Federal, Centro Gráfico, 1988.

Lei federal 6.938/81 - Política Nacional Meio Ambiente.

Lei federal 8.080/90 - Condições de Promoção da Saúde.

Lei Federal 9.433/97 - Política Nacional de Gestão dos Recursos Hidricos

12. BRASIL. MINISTÉRIO DE DESENVOLVIMENTO URBANO E MEIO AMBIENTE. CONSELHO NACIONAL DO MEIO AMBIENTE (CONAMA). Resolução n. 357, D. O. U., de 17/03/05, Brasília.

13. BRASIL. MINISTÉRIO DA SAÚDE. Portaria nº 1469, 2000. Ministério da Saúde do Brasil, D. O. U., de 12/00, Brasília.

14. BRASIL. MINISTÉRIO DA SAÚDE. Portaria n. 518, 2004. Ministério da Saúde do Brasil, D. O. U., de 25 de março de 2004, Brasília. Disponível em: <http://dtr2001.saude.gov.br/sas/PORTARIAS/Port2004/GM/GM-518.htm>. Acesso em: 23 jan. 2004.

15. RESAOLA JR., R.; SARON, A. A menor produção de residuos sólidos, em pesquisa piloto, no tratamento de água de abastecimento por tecnologias diferenciadas. In: ICTR 2004 - CONGRESSO BRASILEIRO DE CIÊNCIA E TECNOLOGIA EM RESIDUOS E DESENVOLVIMENTO SUSTENTÁVEL \& CICLO DE CONFERÊNCIAS SOBRE POLÍtiCA E GESTÃO AMBIENTAL. Out., 2004, Florianópolis.

16. BRINKHURST, R.O.; COOK, G.G. Pollution ecology of freshwater invertebrates. New York, N.Y.: Hart, C.W. and Fuller, S.L.H., 1974.

17. CAMPOS, A.; MENDONÇA, L.; PIRES, E. Utilização do ultra-som na minimização da geração do lodo em sistemas anaeróbios de tratamento. In: CONGRESSO BRASILEIRO DE CIÊNCIA E TECNOLOGIA EM RESÍDUOS E DESENVOLVIMENTO SUSTENTÁVEL. Out., 2004, Florianópolis. 
18. CCME - CANADIAN COUNCIL OF MINISTERS OF THE ENVIRONMENT. Protocol for the derivation of Canadian sediment quality guidelines for the protection of aquatic life. CCME-EPC-98 E. Prepared by Environment Canada, Guidelines Division, Technical Secretariat of the CCME Task Group on Water Quality Guidelines, Ottawa, Canada, 1999.

19. CAPOBIANCO, J.P. Restam apenas $7,3 \%$ da mata atlântica. Parabólicas (Instituto Sócio Ambiental), v. 40, p. 10-11, 1998.

20. CARVALHO, E.H. Disposição de resíduos gerados nas estaçōes de tratamento de água em estações de tratamento de esgoto com decantação primária. 2000. Tese (Doutoramento) - Escola de Engenharia de São Carlos, São Carlos.

21. CETEC; CBH-RB. Relatório de situação dos recursos hídricos da bacia hidrográfica do ribeira de iguape e litoral sul UGRHI 11. Relatório técnico Final, v. 1. Disponível em: $<$ http://sigrh.sp.gov.br/sigrh/ftp/relatorios/CRH/CBH-RB/R0/volume/index.htm>. Acesso em: 05 abr. 2001.

22. CETESB - COMPANHIA DE TECNOLOGIA DE SANEAMENTO AMBIENTAL. Relatório de qualidade da águas interiores do estado de São Paulo de $1999,2000$.

23. CETESB - COMPANHIA DE TECNOLOGIA DE SANEAMENTO AMBIENTAL. Relatório de qualidade da águas interiores do estado de São Paulo de $2000,2001$.

24. CETESB - COMPANHIA DE TECNOLOGIA DE SANEAMENTO AMBIENTAL. Relatório de qualidade da águas interiores do estado de São Paulo de 2004. Disponivel em: <http://www.cetesb.sp.gov.br> Acesso em: 23 jun. 2004.

25. CHARLES, B.; FREDEEN, K.J. Concepts, instrumentation and techniques in inductively coupled plasma optical emission spectrometry. Perkin Elmer, 1997. 
26. CIIAGRO - CENTRO INTEGRADO DE INFORMAÇÕES AGROMETEOROLÓGICAS. Disponível em: <http://www.iac.sp.gov.br/Ciiagro>. Acesso em: 19 nov. 2004.

27. COTRIM, M.E.B.; FURUSAWA, H.A.; DANTAS, S.K.; GELATTI, M.J.G.; BELTRAME FILHO, O.; BANA, B.; PIRES, M.A.F. Caracterização de sedimentos ativos de drenagem em áreas de captação. In: XV ENCONTRO TÉCNICO "SANEAMENTO, DIREITO COM DEVERES" - AESABESP, 30 de Ago. - 01 de Set., 2004, São Paulo.

28. COTRIM, M.E.B.; DANTAS, E.K.; FILHO, O.B.; HIROI, J.; PIRES, M.A.F. Qualidade da água subterrânea utilizada para abastecimento público no Vale do Ribeira SP. In: CONGRESSO BRASILEIRO DE ENGENHARIA SANITÁRIA E AMBIENTAL. 18 - 23 de Set., 2005, Campo Grande/MS.

29. COMBEST, K. Trace metals in sediment: spatial trends and sorption processes. Water Resources Bulletin, American Water Resources Association, v. 27, n. I, 1991.

30. CORDEIRO, J.S. Problema dos lodos gerados nos decantadores em estações de tratamento de água. 1993. Tese (Doutoramento) - Escola de Engenharia de São Carlos, São Carlos.

31. COSIN, S.; KOZIEVITCH, V.; SANTOS, P.; DÍAZ., F. Estudo e caracterização de lodo de estação de tratamento de água visando sua utilização na produção de material cerâmico. In: ICTR - CONGRESSO BRASILEIRO DE CIÊNCIA E TECNOLOGIA EM RESÍDUOS E DESENVOLVIMENTO SUSTENTÁVEL. Out., 2004, Florianópolis.

32. DANTAS, E.S.K. Procedimentos analíticos em determinaçōes multi-elementares de particulados do aerossol atmosférico para uso em modelo receptor. 1999. Dissertação (Mestrado) - Instituto de Química/USP, São Paulo.

33. DAVID, A.C.; SANTOS, C. M. Secagem de lodo da ETA Taiaçupeba disposto na forma de leira em pátio coberto. In: XV Encontro Técnico AESABESP, Ago., 2004, São Paulo. 
34. DHARMAPPA, H.B.; HASIA, A.; HAGARE, P. Water treatment plant residuals management. Wat. Sci. Tech., v. 35, p. 45-56, 1997.

35. DAEE - DEPARTAMENTO DE ÁGUAS E ENERGIA ELÉTRICA. Caracterização dos usos e das disponibilidades hidricas. São Paulo, 1985.

36. ECKENFELDER, W.; SANTHANAM, C. Pollution engineering and technology sludge treatment. New York, N.Y.: Marcel Dekker, 1981.

37. FGV - FUNDAÇÃO GETÚLIO VARGAS. Indicadores de sustentabilidade para a gestão dos recursos hídricos no Brasil. CIDS - Centro Internacional de Desenvolvimento Sustentável - EBAP - Escola Brasileira de Administração Pública. Projeto Indicadores de Sustentabilidade para a Gestão de Recursos Hídricos, 2000.

38. FISZMAN, M.; PFEIFFER, W.C.; LACERDA, L.D. Comparison of methods used for extraction and geochemical distribution of heavy metals in bottom sediments from Sepetiba Bay. Environ. Tech. Letters, v. 5, p. 567-575, 1984.

39. FONTANA, A.O.; CORDEIRO, J.S. Tecnologia integrada como solução para lodos de decantadores e água de lavagem de filtros - Estudo de Caso - ETA Cardoso/SP. In: XV Encontro Técnico AESABESP, Ago., 2004, São Paulo, SP. São Paulo: 2004. 1 CD-ROM.

40. FURREY, M.; ShAEFER, J.; GEHO, M.; GALLO, T. Micro filtration for treatment of waste filter wash water at a North Jersey surface water treatment plant. American Water Works Association - Water Quality Technology Conference Proceedings. Disponivel em: $\measuredangle$ http://www.pal.com/pdf/tu08-1.pdf $>$. Acesso em: 1 nov. 2005:

41. GATTI, L.V. Distribuição de Metais em Testemunhos de Sedimentos de Duas Lagoas Marginais do Rio Mogi - Guaçu (E.E. de Jataí, Luiz Antônio, SP). 1997. Tese (Doutorado) - Escola de Engenharia de São Carlos, São Carlos.

42. GOLDSTEIN, J.I.; YAKOWITZ, H.; NEWBURY, D.E. Practical aspects of $\boldsymbol{X}$ Ray microanalyses. In: GOLDSTEIN, J.I., YAKOWITZ, H. Practical scanning electron microscopy: electron and ion microscope analysis. New York, N. Y.: Plenum, 1976. 
43. GONÇALVES, R.F.; BRANDÃO, J.T.; BARRETO, E.M.S. Viabilidade econômica da regeneração do sulfato de alumínio de lodos de estações de tratamento de águas. In: $20^{\circ}$ CONGRESSO BRASILEIRO DE ENGENHARIA SANITÁRIA E AMBIENTAL, II 045, p. 1298-1306, 1999.

44. GRANDIN, S.R. Desidratação dos lodos produzidos nas estações de tratamento de água. 1992. Dissertação (Mestrado) - Escola Politécnica/USP, São Paulo.

45. GUERRA, R.C.; ANGELIS, D.F.D. Classificação e biodegradação de lodo de estações de tratamento de água para descarte em aterro sanitário. Arq. Inst. Biol., v. 72, n. 1, p. 87-91, 2005.

46. HIRABAYASHI K.; YOSHIZAWA K.; YOSHIDA N.; KAZAMA F. Progress of eutrophication and change of chironomid fauna in lake Yamanakako. Limnology, v. 5, p. 47-53, 2004.

47. HOGAN, D.J.; CARMO, R.L.; ALVES, H.P.F.; RODRIGUES, I.A. Desenvolvimento sustentável no Vale do Ribeira (SP): conservação ambiental e melhoria das condições de vida da população. 1998. Disponivel em: <http:// www.unicamp.br/nepo/staff/roberto/valeribeira.htm>. Acesso em: 13 mar. 2002.

48. HOPPEN, C.; PORTELLA, K. F.; ANDREOLI, C.V.; SALES, A.; JOUKOSKI, A. Estudo de incorporação do lodo centrifugado da estação de tratamento de água Passaúna em matrizes de concreto, com dosagem de 3\%. In: CONGRESSO BRASILEIRO DE ENGENHARIA SANITÁRIA E AMBIENTAL. 2003, Joinville.

49. MÉTODOS GERAIS DE TRATAMENTO DE ÁGUA: decantação. Disponível em: < http://www.ocaminhodaagua.hpg.ig.com.br/dec.html>. Acesso em: 29 jun. 2004.

50. IBGE - INSTITUTO BRASILEIRO DE GEOGRAFIA E ESTATÍSTICA. Pesquisa Nacional de Saneamento Básico 2000 (PNSB). 2002, Brasília. 
51. JACKSON, R.B.; CARPENTER, S.R.; DAHM, C.N.; MCKNIGHT, D.M.; NAIMAN, R.J.; POSTEL, S.L.; RUNNING, S.W. Ecological Applications, Water in a Changing World, v. 11, p. 1027-1045, 2001.

52. JOINT COMMITTEE FOR POWDER DIFFRACTION STUDIES INTERNATIONAL CENTRE FOR DIFFRACTION DATA. USA, 1997.

53. JOASSON, P.M.; Botton fauna and eutrophication. In: Proceedings of the Symposium of the National Academy of Science - Eutrophication: causes, consequences and correctives. National Academy of Science, p. 274-305. EUA, 1969.

54. KAGGWA, R.; MULALELO, C.; DENNY, P.; OKORUT, T. The impact of alum discharges on a natural tropical wetland in Uganda. Water Research, v. 35, n. 3, p. 795$807,2001$.

55. KATSUOKA, L. Avaliação do impacto da atividade agropecuária da qualidade da água em áreas de captação superficial nas bacias hidrográficas dos rios Mogi Guaçu e Pardo. 2001. Tese (Doutoramento) - IPEN/ USP, São Paulo.

56. KAWAMURA, 1991. Cianobactérias tóxicas na água para consumo humano na saúde pública e processos de remoção em água para consumo humano. Brasília: Ministério da Saúde: Fundação Nacional de Saúde, 2003.

57. KAWAMURA, S. Integrated design of water treatment facilities. New York, N.Y.: John Wiley \& Sons, 1991.

58. KINGSTON, H.M.; HASWELL, S.J. Microwave-enhanced chemistry fundamentals, sample preparation and applications. American Chemical Society, Washington, D.C., 1997.

59. KNOBLAUCH, P.M.; MIBIELLI, G.; FRANÇA, R. Incorporação de lodo de estação de tratamento de água em blocos cerâmicos. In: CONGRESSO BRASILEIRO DE CIÊNCIA E TECNOLOGIA EM RESÍDUOS E DESENVOLVIMENTO SUSTENTÁVEL, Out., 2004, Florianópolis. 
60. LEMES, M.J.L. Avaliação de metais e elementos-traço em águas e sedimentos das bacias hidrográficas dos rios Mogi - Guaçu e Pardo. 2001. Dissertação (Mestrado) IPEN/ USP, São Paulo.

61. LESTER, J.N. Heavy metals in wastewater and sludge treatment processes. CRC Press, Boca Raton, 1987.

62. LINO, C.F. (ed.). 1992. Reserva da biosfera da Mata Atlântica - Plano de ação. Consórcio Mata Atlântica e Universidade Estadual de Campinas, v. 1, 1992.

63. MACHADO, L.; PEREIRA, J.; PONTE, M.; LOPES, L. Avaliação do aproveitamento agrícola do lodo produzido na ETA Bolonha - RMB. In: CONGRESSO BRASILEIRO DE CIÊNCIA E TECNOLOGIA EM RESÍDUOS E DESENVOLVIMENTO SUSTENTÁVEL, Out., 2004, Florianópolis.

64. MARQUES, M.N.; COTRIN, M.E.B. ; PIRES, M.A.F. 2003. Pesticide monitoring in Ribeira Valley, Southeastern Brazilian. In: IX Congresso mundial de água, Out., 2003, Madri.

65. MARQUES, M.N. Avaliação do impacto de agrotóxicos em áreas de proteção ambiental, pertencentes à bacia hidrográfica do rio Ribeira Iguape, São Paulo. Uma contribuição à análise crítica da legislação sobre o padrão de potabilidade. 2005. Tese (Doutorado) - IPEN/ USP, São Paulo.

66. MIYAHARA, R.Y.; DIAZ, F.; TOFFOLI, S.M. Estudo comparativo do comportamento mecânico de corpos de prova de argila comum contendo lodos de estação de tratamento de água conformados manualmente e por prensagem uniaxial. In: CONGRESSO BRASILEIRO DE CIÊNCIA E TECNOLOGIA EM RESÍDUOS E DESENVOLVIMENTO SUSTENTÁVEL, Out., 2004, Florianópolis.

67. MORAES, L.; BERGAMASCO, R.; TAVARES, C.; GUEDES, T. Estudo do Processo de Coagulação/Floculação Seguido de Filtração Direta para a Produção de Água Potável. In: CONGRESSO BRASILEIRO DE CIÊNCIA E TECNOLOGIA EM RESÍDUOS E DESENVOLVIMENTO SUSTENTÁVEL, Out., 2004, Florianópolis. 
68. MOREIRA, F.; MOREIRA, J. A Importância da Análise de Especiação do Chumbo para a Avaliação dos Riscos à Saúde. Química Nova, v. 27, , n. 2, p. 251-260, 2004.

69. MORITA, D.; SAMPAIO, A.; MIKI, M.; DAVID, A. Incorporação de lodos de estações de tratamento de água em blocos cerâmicos. In: $10^{\circ}$ SIMPÓSIO LUSOBRASILEIRO DE ENGENHARIA SANITÁRIA, SILUBESA, 2002, Lisboa.

70. MUÑOZ, S. Impacto ambiental na área do aterro sanitário e incinerador de resíduos sólidos de Ribeirão Preto, SP: avaliação dos níveis de metais pesados. 2002. Tese (Doutorado) - Escola de Enfermagem de Ribeirão Preto/USP, Ribeirão Preto.

71. MURRAY, K.; DILLON, G. Waterworks Residuals Management: a Comparison of US and UK Practices, p. 4-37-4-47, 1994.

72. NUVOLARI, A. Inertização de lodo de esgoto em tijolos maciços: Aspectos tecnológicos e ambientais. 2002. Tese (Doutorado) - Faculdade de Engenharia Civil/UNICAMP, Campinas.

73. OLIVEIRA, M.J.E.; ASSIS, C.S. Resíduos de construção: desenvolvimento sustentável. In: 20 CONGRESSO BRASILEIRO DE ENGENHARIA SANITÁRIA E AMBIENTAL. 2001, Rio de Janeiro, RJ.

74. PADILHA, A.F.; AMBROSIO FILHO, F. Difração de RX. Técnicas de análise micro estrutural. São Paulo, SP: Hemus, 1985.

75. PARSEKIAN, M.P.S. Análise e proposta de formas de gerenciamento de estações de tratamento de águas de abastecimento. 1998. Dissertação (Mestrado) Escola de Engenharia de São Carlos, São Carlos.

76. PARSEKIAN, M.P.S.; PIRES, E. Tratamento ultra-sônico do lodo excedente de sistema combinado de tratamento de água residuária. CONGRESSO BRASILEIRO DE CIENCIA E TECNOLOGIA EM RESIDUUOS E DESENVOLVIMENTO SUSTENTÁVEL., Out., 2004, Florianópolis. 
tratamento de água do sistema rio Manso/COPASA do município de Brumadinho - MG com cerâmica vermelha. CONGRESSO BRASILEIRO DE CIÊNCIA E TECNOLOGIA EM RESÍDUOS E DESENVOLVIMENTO SUSTENTÁVEL, Out., 2004, Florianópolis.

78. PENNAK, R. W. Freshwater invertebrates of United States. New York, N.Y.: Ronald, 1953.

79. PIRES, M.A.F. et al. Qualidade da água para consumo humano: uma oportunidade de avaliação da concepção e aplicabilidade da nova legislação - Portaria 1469/MS/00. Revista Brasileira de Pesquisa e Desenvolvimento, v. 3, p. 127-138, 2001.

80. PIRES, M.A.F. Programas de avaliação de risco. Relatório de Viagem. IPEN/CNEN-SP, Dez., 1999.

81. PIRES, M.A.F.; Cotrim, M.E B. Modelagem diagnóstica e prognóstica da qualidade da água em áreas de captação. Relatório técnico-científico. PADCT/FINEP, Mar., 2000.

82. PROSAB - PROGRAMA DE PESQUISA EM SANEAMENTO BÁSICO. Noções gerais de tratamento e disposição final de estações de tratamento de água. Marco Antônio Penaldi Reali, Rio de Janeiro: ABES - Projeto PROSAB, 1999.

83. RAURET, G. Extraction procedures for the determination of heavy metals in contaminated soil and sediment. Talanta, v. 46, p. 449-455, 1998.

84. REALI, M. P. Noções gerais de tratamento e disposição final de lodos de estações de tratamento de água. PROSAB, 1999.

85. REDICDIT, T.M. Control of colloidal stability through zeta potential, ZETA Meter Inc. Livington.

86. REIS, E. L. T.; COTRIM, M. E.; FILHO, O. B.; BADIRU, A. I., PIRES, M. A. F. A monitoring study for the impact evaluation of water treatment sludge discharge on Ribeira de Iguape River, São Paulo, Brazil. $4^{\text {th }}$ IWA World Water Congress and Exhibition, Sep., 2004, Marrakech, Marrocos. 
87. REIS, E. L. T.; COTRIM, M.E.; FILHO, O.B.; Pinto, O. E.; SOUZA, A.L.F.; AMALFI, P.Z.; PIRES, M.A.F. Caracterização química de residuos gerados em sistemas de tratamento de água. XV Encontro Técnico SABESP, Ago., 2004, São Paulo, Brasil.

88. REIS, E. L. T.; COTRIM, M.E.; FILHO, O.B.; SOUZA, A.L.F.; AMALFI, P.Z.; RODRIGUES, C.; PIRES, M.A.F. Sludge characterization from a water treatment plant on Ribeira de Iguape river by inductively coupled plasma optical emission spectrometry. Proceedings: $8^{\text {TH }}$ RIO SYMPOSIUM ON ATOMIC SPECTROMETRY, Aug., 2004, Parati, RJ.

89. REIS, E.L.T.; COTRIM, M.E.; FILHO, O.B.; SOUZA, A.L.F.; AMALFI, P.Z.; PIRES, M.A.F. Impacto ambiental dos resíduos gerados em sistemas de tratamento de água no Rio Ribeira de Iguape, São Paulo, Brasil. In: ICTR 2004 - CONGRESSO BRASILEIRO DE CIÊNCIA E TECNOLOGIA EM RESÍDUOS E DESENVOLVIMENTO SUSTENTÁVEL \& CICLO DE CONFERÊNCIAS SOBRE POLÍTICA E GESTÃO AMBIENTAL, Out., 2004, Florianópolis.

90. REIS, E. L. T.; COTRIM, M. E.; FILHO, O. B.; BADIRU, A. I., PIRES, M. A. F. A monitoring study for the impact evaluation of water treatment sludge discharge on Ribeira de Iguape River, São Paulo, Brazil. Water Supply, IWA Publishing, v. 4, n. 5-6, p. 139-146, 2005

91. RICHTER, C.A. Tratamento de lodos de estações de tratamento de água. São Paulo, S.P.: Edgard Blücher Ltda., 2001.

92. ROCHA, S.M. Macro invertebrados bentônicos como indicadores de poluição na represa do Guarapiranga-SP. 1999. Dissertação (Mestrado) - Faculdade de Saúde Pública/USP, São Paulo.

93. SABESP - COMPANHIA DE SANEAMENTO BÁSICO DO ESTADO DE SÃO PAULO. Tratamento e disposição final do lodo de estação de tratamento de água. Diretoria de Sistemas Regionais - R. Superintendência de Gestão e Desenvolvimento Operacional de Sistemas Regionais - RO Departamento de Controle Sanitário e Ambiental - ROA. Relatório interno. Abr., 2003. 
94. SABESP - COMPANHIA DE SANEAMENTO BÁSICO DO ESTADO DE SÃO PAULO. Padrões para controle dos materiais utilizados no tratamento de água. Departamento de Controle de Qualidade - Superintendência de Apoio Técnico da Operação. Relatório Interno. Revisão Jun., 1993.

95. SALOMONS, W.; STIGLINI, W.M. Biogeodynmics of pollutants in soils and sediments - risk assessment of delayed and non-linear responses. Berlin: Springer Verlag, 1995.

96. SANTOS, E.J. Determinação de nutrientes e contaminantes inorgânicos em café solúvel por espectrometria de emissão atômica com plasma de argônio induzido (ICPAES). 1999. Dissertação (Mestrado) - Instituto de Química/USP, São Paulo.

97. SÃO PAUlO. CONSTITUIÇÃO DO ESTADO DE SÃO PAULO. Assemblëia Legislativa do Estado de São Paulo, 1989.

Lei estadual 7.663/91 - Política Estadual de Recursos Hídricos.

Lei estadual 7.750/92 - Política Estadual de Saneamento.

Lei Estadual 9.866/97 - Política Estadual de Proteção aos Mananciais

98. SCALIZE, P.S. Disposição de resíduos gerados em estaçōes de tratamento de água em estações de tratamento de esgoto. 2003. Tese (Doutorado) - Escola de Engenharia deSão Carlos, São Carlos.

99. SCAPIN, M.A. Aplicação da difração e fluorescência de raios X (WDXRF): ensaios em argilominerais. 2003. Dissertação (Mestrado). IPEN/USP, São Paulo.

100. SCHIMITT, C.R.; HALL, J.E. Analytical characterization of water-treatment plant sludge. J. $A W W A$, v. 67 , p. $40-42,1975$.

101. SCHRAMEL, P. ICP and DCP emission spectrometry for trace element analysis in biomedical and environmental samples: a review. Spectrochimica Acta, v. 43B, 1988. 
102. SIQUEIRA, S.R. Estudo de caso: obtenção da licença ambiental preliminar para a implantação de um aterro exclusivo das tortas de lodo geradas na estação de tratamento de água Taiaçupeba. In: XV ENCONTRO TÉCNICO AESABESP, Ago., 2004, São Paulo.

103. SOTOMAYOR, O.A. A model reference for evaluating control strategies in activated sludge wastewater treatment plants. In: INTERNATIONAL RESEARCH CONFERENCE ON WATER REUSE AND WATER TREATMENT PLANTS OPERATIONS. 1999, Toulouse, France.

104. SPECTRO. User's guide of Spectro ICP-AES, Manual do Usuário, 240p, 1999.

105. SPERLING, M.V.; NASCIMENTO, L.V. A resolução CONAMA 20/86 e as legislações estaduais de classificação das águas e lançamento de efluentes. In: $20^{\circ}$ CONGRESSO BRASILEIRO DE ENGENHARIA SANITÁRIA E AMBIENTAL, 2001, Rio de Janeiro, RJ.

106. THE SPECTROMETRY NET. Disponivel em $\langle$ http://icp-oes.com $>$. Acesso em: 15 jul. 2005.

107. STATSOFT INCORPORATION. Statistica and statistica industrial system, Tulsa: USA, 1998.

108. THOMPSON, M. Analytical Performance of Inductively Coupled Plasma Atomic Emission Spectrometry. New York, N.Y.: VHC INC, p. 163-199, 1987.

109. TUMEO, M.A. Effects of lime-sludge discharge on an Artic river. Water Resources Bulletin, American Water Resources Association, p. 1083-1094, 1992.

110. USEPA - U. S. ENVIRONMENTAL PROTECTION AGENCY. Processing design manual for sludge treatment and disposal. Cincinnati, 1047 p., 1979.

111. USEPA - U. S. ENVIRONMENTAL PROTECTION AGENCY. Test methods for evaluating solid waste. Physical/Chemical Methods, $3^{\text {rd }}$ Edition, Final Update III, 1996.

112. USEPA - UNITED STATES ENVIRONMENTAL PROTECTION AGENCY. Handbook - Remediation of contaminated sediments. USEPA/625/6-91/028, 1991. 
113. VON SPERLING, M. Princípios do tratamento biológico de águas residuárias. Introdução à qualidade das águas e ao tratamento de esgotos. Departamento de Engenharia Sanitária e Ambiental - UFMG. Belo Horizonte, 1996.

114. WORLD BANK. The new water resources strategy. 2004. Disponivel em: <http://nwebl 8.worldbank.org>. Acesso em: 18 ago.2004.

115. YABE, M.J.S. Determinação de metais pesados em águas superficiais por ICPOES objetivando caracterização e recuperação de bacias hidrográficas. 1995. Tese (Doutorado) - USP, São Paulo. 
